\title{
Investigations of
}

Sediment Transportation Middle Loup River At Dunning, Nebraska

GEOLOGICAL SURVEY WATER-SUPPLY PAPER 1476

Prepared in cooperation with the U. $S$. Bureau of Reclamation as part of a program of the Department of the Interior for development of the Missouri River basin

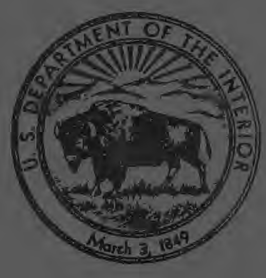




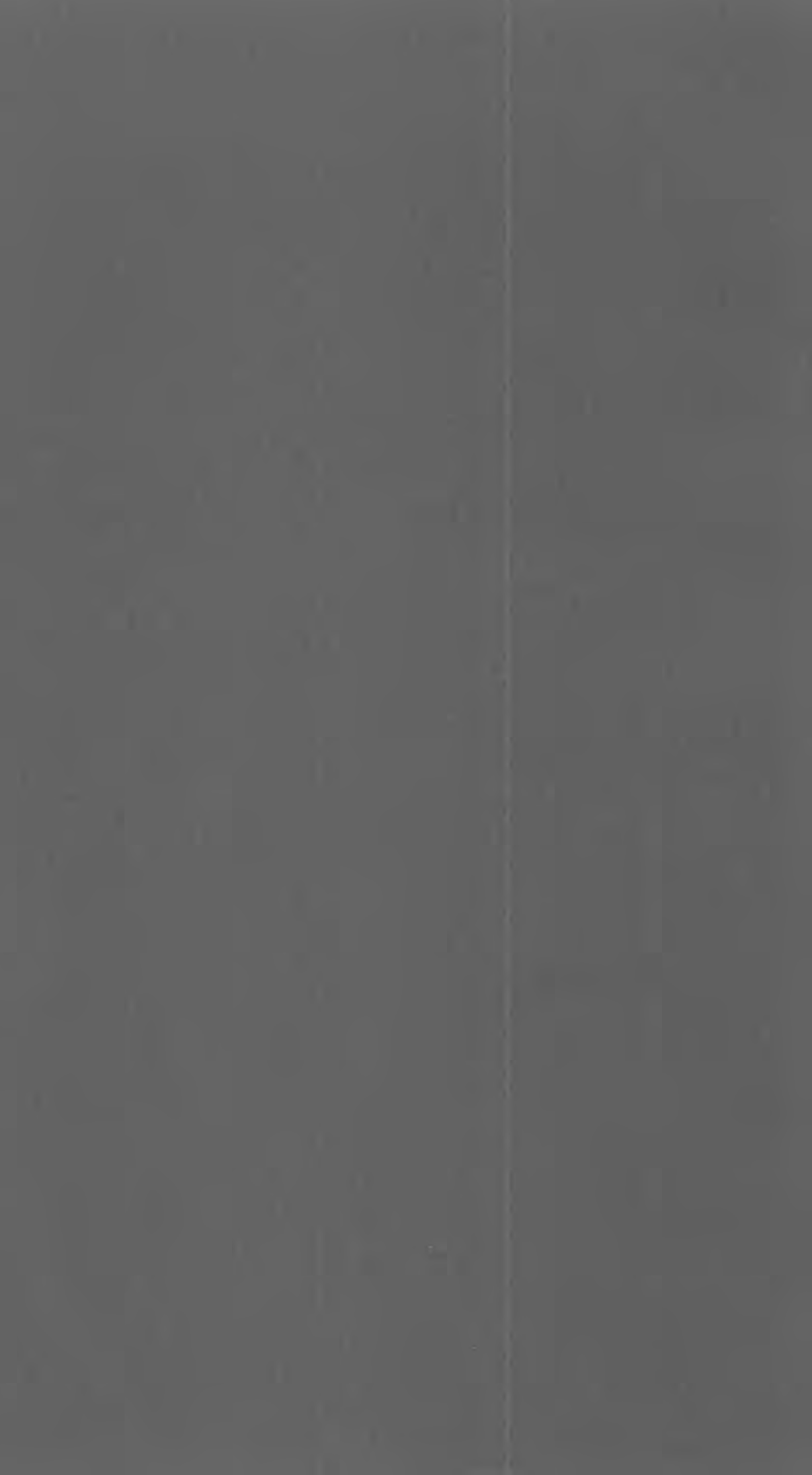




\section{Investigations of}

Sediment Transportation Middle Loup River At Dunning, Nebraska

With APPLICATION OF DATA FROM TURBULENCE FLUME By D. W. HUBBELL and D. Q. MATEJKA

GEOLOGICAL SURVEY WATER-SUPPLY PAPER 1476

Prepared in cooperation with the $U . S$. Bureau of Reclamation as part of a program of the Department of the Interior for development of the Missouri River basin

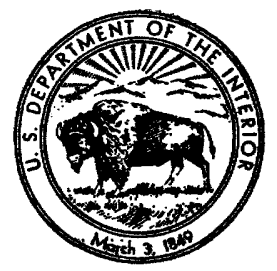




\title{
UNITED STATES DEPARTMENT OF THE INTERIOR
}

\author{
FRED A. SEATON, Secretary
}

\section{GEOLOGICAL SURVEY}

Thomas B. Nolan, Director

The U. S. Geological Survey Library has cataloged this publication as follows:

\section{Hubbell, David Wellington, 1925-}

Investigations of sediment transportation, Middle Loup River at Dunning, Nebraska, with application of data from turbulence flume, by D. W. Hubbell and D. Q. Matejka. Washington, U. S. Govt. Print. Off., 1959.

vi, 123 p. illus., maps, diagrs., tables. $25 \mathrm{~cm}$. (U. S. Geological Survey. Water-supply paper 1476)

Part of illustrative matter folded in pocket.

"Prepared in cooperation with the U. S. Bureau of Reclamation as part of a program of the Department of the Interior for development of the Missouri River Basin."

Bibliography : p. 78-79.

1. Sedimentation and deposition. 2. Sediments (Geology)-Nebraska-Dunning. 3. Middle Loup River, Nebraska. I. Matejka, Donald Quintin, 1922TC801.U2 No. 1476 joint author.

(Series) 551.35 G S 59-156 Copy 2. QE581.H8 


\section{CONTENTS}

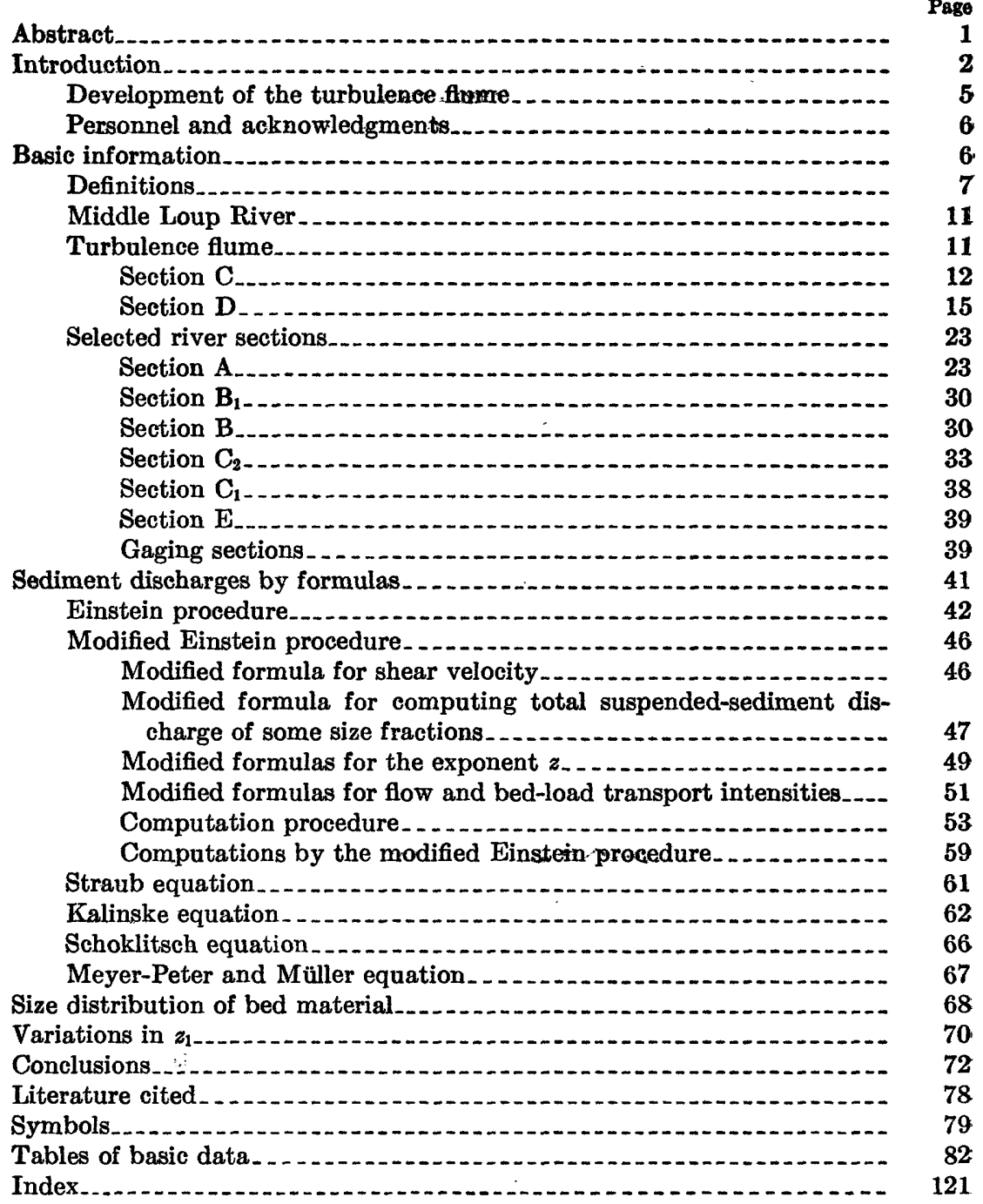




\section{ILLUSTRATIONS}

[Plates 6-13 are in pocket]

Page

6. Correction $x$ in terms of $k_{a} / \delta$.

7. Computation of total sediment discharge.

8. Relation of $\Phi_{*}$ to $\Psi_{*}$.

9. $J_{1}$ in terms of $A$ and $z$.

10. $-J_{2}$ in terms of $A$ and $z$.

11. Function $I_{1}{ }^{\prime \prime}$ in terms of $A^{\prime \prime}$ and $z$.

12. Multipliers for computing $z^{\prime}$ s for each size fraction from the reference $z$.

13. Function $-I_{2}{ }^{\prime \prime}$ in terms of $A^{\prime \prime}$ and $z$.

Fraure 1. Map of the Loup River basin, Nebraska.

2. Rea

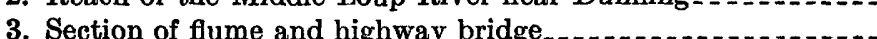

3. Section of fume and highway bridge

4. Water-surface profile, July 8, 1952

5. Particle-size distributions of measured suspended sediment and bed material, sections $\mathbf{C}$ and $\mathrm{D}$.

6. Lateral distributions of depth, stream velocity, and measured suspended-sediment concentration, section $\mathbf{C}$

7. Vertical distributions of suspended-sediment concentration, velocity, and percent coarser than $0.25 \mathrm{~mm}$, section C, July 18,1950

8. Sediment-transport curve for section $D$ at the turbulence flume.

9. Variation of the percentages of suspended sediment in size ranges with concentration, section $D$

10. Lateral distributions of depth, stream velocity, and measured suspended-sediment concentration, section $D$.

11. Vertical distributions of suspended-sediment conoentration, velocity, and percent coarser than $0.25 \mathrm{~mm}$, section $\mathrm{D}$, August 30, 1950

12. Vertical distributions of suspended-sediment concentration, velocity, and percent coarser than $0.25 \mathrm{~mm}$, section $D$, August 13, 1952.

13. Vertical distributions of suspended-sediment concentration, velocity, and percent coarser than $0.25 \mathrm{~mm}$, section $\mathrm{D}$, September 10, 1952

14. Particle-size distributions of measured suspended sediment

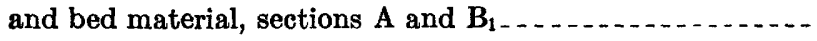


Fraven 15. Lateral distributions of depth, stream velocity, and measured suspended-sediment concentration, section $A$

16. Lateral distributions of depth, stream velocity, and measured suspended-sediment concentration, section $\mathrm{B}_{1 \ldots} \ldots \ldots$

17. Lateral distributions of depth, stream velocity, and measured suspended-sediment concentration, section B..........

18. Vertical distributions of suspended-sediment concentration, velocity, and percent coarser than $0.25 \mathrm{~mm}$, section $B$,

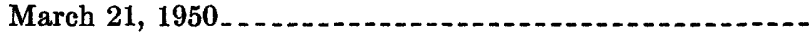

19. Lateral distributions of depth and stream velocity, 25 feet upstream from section B . . . . . . . . . . . . . . . .

20. Particle-size distributions of measured suspended sediment and bed material, sections $\mathrm{C}_{2}$ and $\mathrm{E} \ldots \ldots \ldots$

21. Lateral distributions of depth, stream velocity, and measured suspended-sediment concentration, section $\mathrm{C}_{2} \ldots \ldots . . . . .$.

22. Lateral distributions of depth and stream velocity, section $\mathbf{C}_{1-}$

23. Lateral distributions of depth, stream velocity, and measured suspended-sediment concentration, section $\mathrm{E}$.

24. Total sediment discharge computed from Einstein procedure plotted against measured total sediment discharge at section D.

25. $z_{1}$ plotted against $z_{m}$

26. Vertical distribution of streamflow

27. Approximate relation of $z_{2}$ to the ratio of suspended-sediment discharge in the sampling zone to bed-load discharge.......

28. Computed sediment discharge from modified Einstein procedure plotted against measured total sediment discharge at section $\mathrm{D}$

29. $\widetilde{U}_{g} / \bar{U}$ in terms of $\tau_{e} / \tau_{0}$

30. Computed bed-load discharge plotted against concentration of measured suspended sediment coarser than $0.125 \mathrm{~mm}$....-

31. Lateral variation of the size distribution of bed material, section E, May 6, 1952 .

32. Vertical variation of the size distribution of bed material, section E, station 77, May 6, 1952 .

33. Variation of median particle size of bed material with water temperature and discharge

34. Fall velocity of quartz spheres in water.

35. $z_{1}$ plotted against $z_{2} \ldots$

36. $z_{1}$ plotted against $k$ for some Nebraska sandhill streams......

37. $z_{1}$ expressed as a power of $z$

38. Variation of fall velocity with temperature from the Rubey equation . . - 


\section{TABLES}

TABLE 1. Water and suspended-sediment discharge measurements....... 82

2. Cross-section soundings:

3. Particle-size analyses of measured suspended sediment, depth-

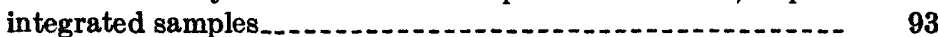

4. Particle-size analyses of bed material

5. Particle-size analyses of measured suspended sediment, point-

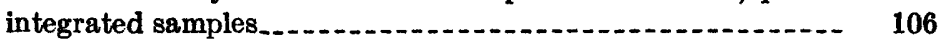

6. Monthly and annual summary of water and total sediment dis-

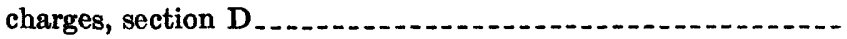

7. Sediment discharge computed with the Einstein procedure for the selected river sections and the comparable measured

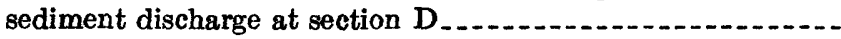

8. Sediment discharge computed with the modified Einstein procedure for the selected river sections and the comparable measured sediment discharge at section $\mathrm{D}$

9. Sediment discharges computed with several formulas and data for comparison..... 


\title{
INVESTIGATIONS OF SEDIMENT TRANSPORTATION, MIDDLE LOUP RIVER AT DUNNING, NEBRASKA
}

\author{
By D. W. Hubbell and D. Q. Matejka
}

\begin{abstract}
An investigation of fluvial sediments of the Middle Loup River at Dunning, Nebr., was begun in 1946 and expanded in 1949 to provide information on sediment transportation. Construction of an artificial turbulence flume at which the total sediment discharge of the Middle Loup River at Dunning, Nebr., could be measured with suspended-sediment sampling equipment was completed in 1949. Since that time, measurements have been made at the turbulence flume and at several selected sections in a reach upstream and downstream from the flume.

The Middle Loup River upstream from Dunning traverses the sandhills region of north-central Nebraska and has a drainage area of approximately 1,760 square miles. The sandhills are underlain by the Ogallala formation of Tertiary age and are mantled by loess and dune sand. The topography is characterized by northwest-trending sand dunes, which are stabilized by grass cover. The valley floor upstream from Dunning is generally about half a mile wide, is about 80 feet lower than the uplands, and is composed of sand that was mostly stream deposited. The channel is defined by low banks. Bank erosion is prevalent and is the source of most of the sediment load. The flow originates mostly from ground-water accretion and varies between about 200 and 600 cfs (cubic feet per second). Measured suspended-sediment loads vary from about 200 to 2,000 tons per day, of which about 20 percent is finer than 0.062 millimeter and 100 percent is finer than 0.50 millimeter. Total sediment discharges vary from about 500 to 3,500 tons per day, of which about 10 percent is finer than 0.062 millimeter, about 90 percent is finer than 0.50 millimeter, and about 98 percent is finer than 2.0 millimeters. The measured suspended-sediment discharge in the reach near Dunning averages about one-half of the total sediment discharge as measured at the turbulence flume.

This report contains information collected during the period October 1, 1948, to September 30, 1952. The information includes sediment discharges; particlesize analyses of total load, of measured suspended sediment, and of bed material; water discharges and other hydraulic data for the turbulence flume and the selected sections.

Sediment discharges have been computed with several different formulas, and insofar as possible, each computed load has been compared with data from the turbulence flume. Sediment discharges computed with the Einstein procedure did not agree well, in general, with comparable measured loads. However, a satisfactory representative cross section for the reach could not be determined with the cross sections that were selected for this investigation. If the computed cross section was narrower and deeper than a representative cross section for the reach, computed loads were high; and if the computed cross section was wider and shallower than a representative cross section for the reach, computed loads were low.
\end{abstract}


Total sediment discharges computed with the modified Einstein procedure compared very well with the loads of individual size ranges and the measured total loads at the turbulence flume. Sediment discharges computed with the Straub equation averaged about twice the measured total sediment discharge at the turbulence flume. Bed-load discharges computed with the Kalinske equation were of about the right magnitude; however, high computed loads were associated with low total loads, low unmeasured loads, and low concentrations of measured suspended sediment coarser than 0.125 millimeter. Bed-load discharges computed with the Schoklitsch equation seemed somewhat high; about one third of the computed loads were slightly higher than comparable unmeasured loads. Although, in general, high computed discharges with the Schoklitsch equation were associated with high measured total loads, high unmeasured loads, and high concentrations of measured suspended sediment coarser than 0.125 millimeter, the trend was not consistent. Bed-load discharges computed with the Meyer-Peter and Müller equation varied progressively with changes in several hydraulic parameters, compared reasonably with total and unmeasured sediment discharges, and increased fairly consistently as the concentration of measured suspended sediment coarser than 0.125 millimeter increased.

Size analyses indicated that bed material varies both laterally and vertically. Composites of at least five samples, but preferably more, seem to be necessary for an adequate determination of the bed-material size distribution. The size distribution for the top 1 inch or so of the bed is generally finer than that for the top 6 inches. The bed-material size distribution determined from 6-inch core samples does not seem to vary with either water temperature or water discharge.

Values of $z_{1}$, the measured exponent for the equation of the vertical distribution of suspended sediment, that are less than about 0.7 are generally larger than associated $z$ 's that are determined from the theoretical equation. Values of $z_{1}$ varied inversely with about the $\mathbf{0 . 6}$ power of $k$, the Von Karman coefficient tor turbulent exchange, throughout a range for $k$ of 0.4-4.00. Also, $z_{1}$ can be expressed roughly as a power of $z$; the power depends on which system of fall velocities is used.

\section{INTRODUCTION}

The investigation of fluvial sediments of the Middle Loup River at Dunning, Nebr. (fig. 1), was begun on April 11, 1946. This investigation was undertaken at the request of and in cooperation with the U. S. Bureau of Reclamation and was made as a part of the program of the Department of Interior for the development of the Missouri River basin. Initially, suspended-sediment measurements were made at a partly contracted section. In 1948, at the request of the Bureau of Reclamation, an artificial turbulence flume at which the total sediment discharge of the Middle Loup River could be measured was designed and constructed. After the turbulence flume was completed in May 1949, the investigation was expanded to include periodic measurements in an alluvial reach upstream and downstream from the flume. In this reach, measurements were made at six river sections (fig. 2), which represent different channel configurations, in order to relate the characteristics of the flow and sediment with sediment discharge. However, no more than five sections were used during the same period of time; consequently, the periods of record 


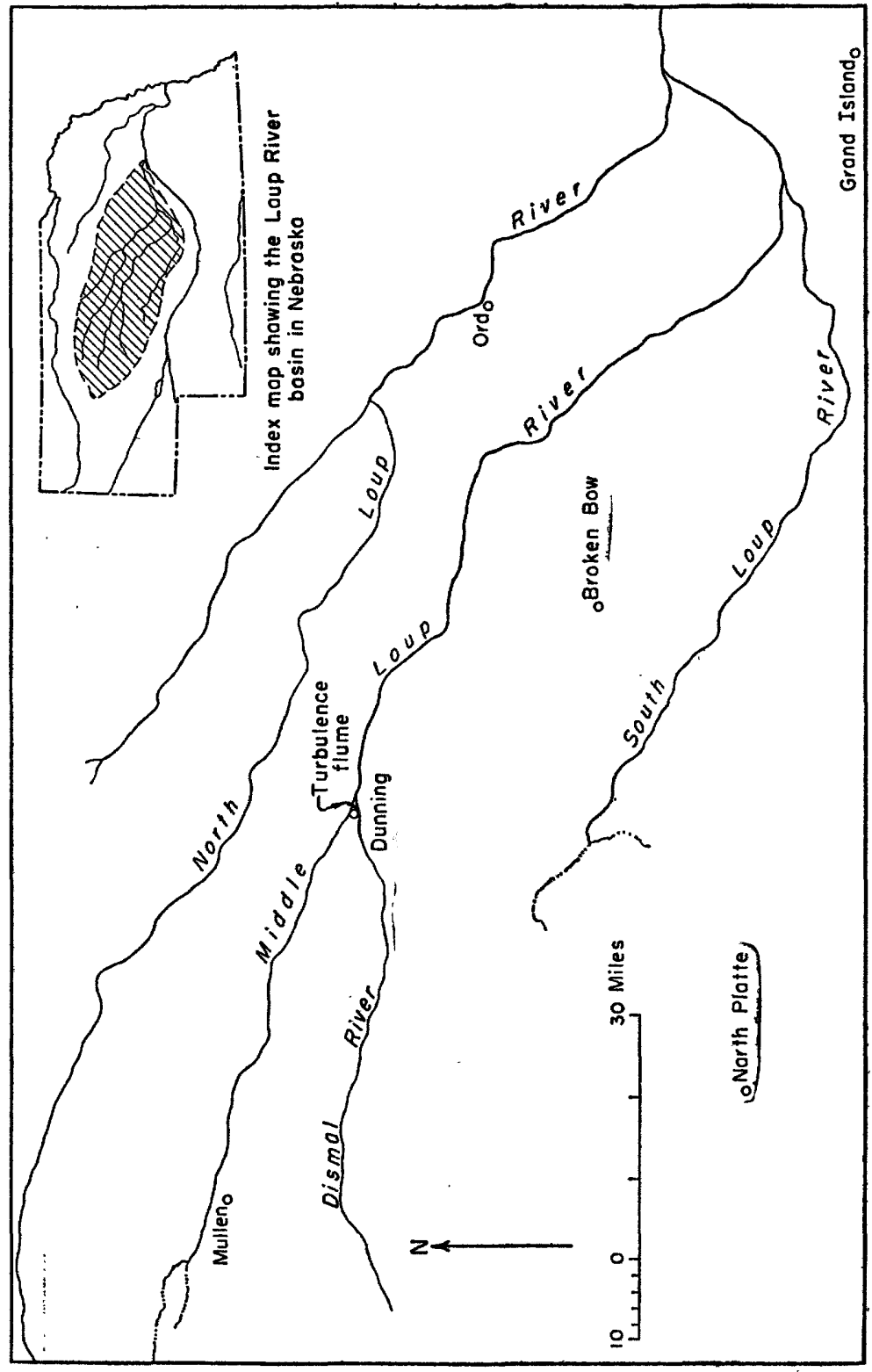

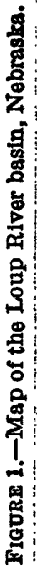


4 SEDIMENT TRANSPORTATION, MIDDLE LOUP RIVER, NEBR.

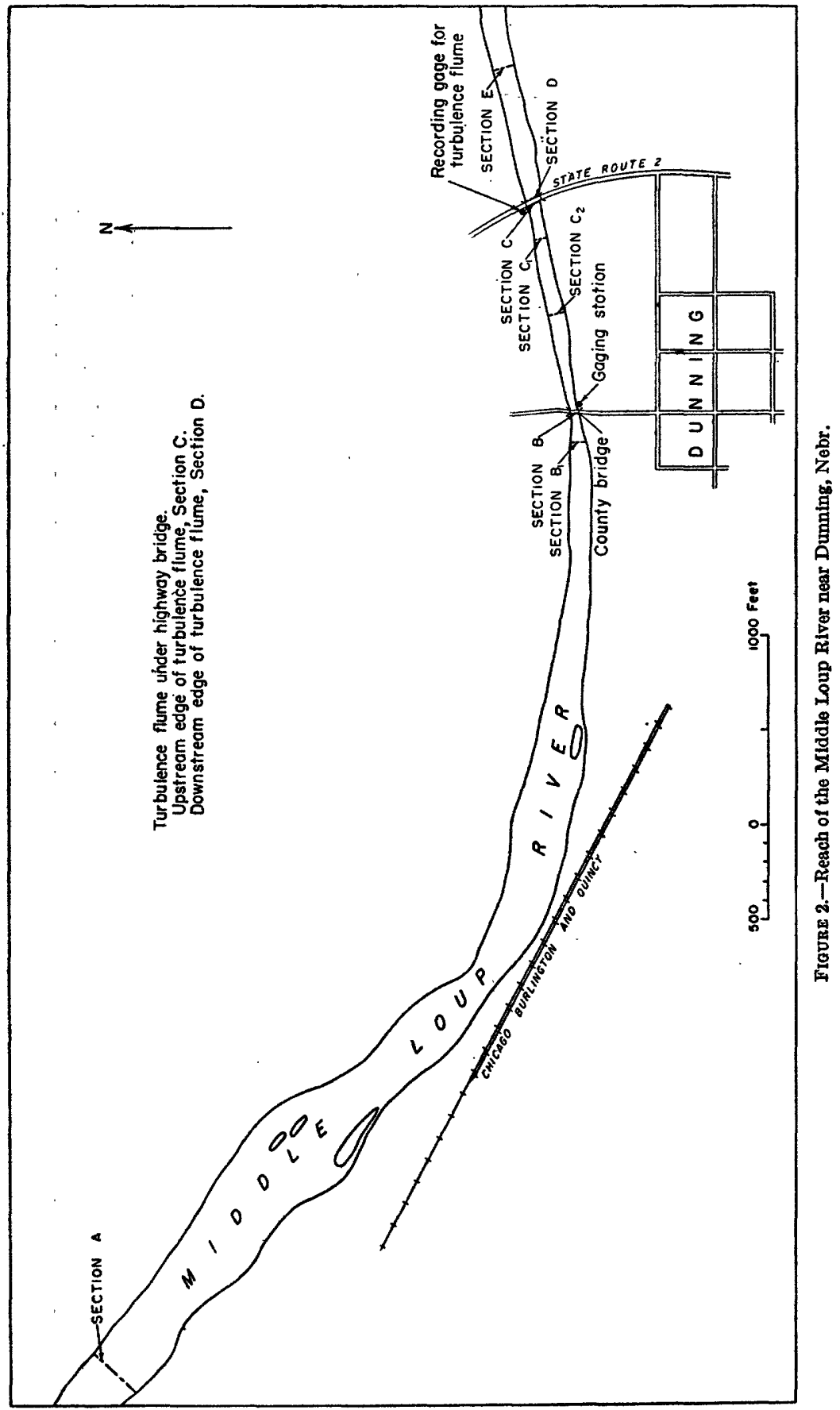


for the different sections varied. After March 20, 1950, daily measurements of suspended-sediment discharge were discontinued at the partly contracted section, and the daily total sediment discharge was measured at the flume.

This report was prepared to summarize the data from this investigation and to show the results of sediment-transport studies that are based on these data-particularly comparisons of measured sediment discharges with sediment discharges computed from formulas. Specifically, the report contains a summary of sediment data and associated hydraulic information for the turbulence flume and the six river sections during the period October 1, 1948, to September 30, 1952 ; computations of sediment discharge by several different methods, including a modification of the Einstein functions (Colby and Hembree, 1955); evaluations of several methods for computing sediment discharge; and a discussion of some aspects of sediment transport on the basis of the field data.

Included in this report are data presented by Vice and Serr (written communication) for the period August 17 to September 14, 1949, some computations of sediment discharge by E. L. Pemberton in 1950 (written communication), and some of the information from P. C. Benedict, M. L. Albertson, and D. Q. Matejka (1955).

\section{DEVELOPMENT OF THE TURBULFNCE FLUME}

The turbulence flume constructed to provide information on total sediment discharge. :Such information was needed for determining accurately the annual total sediment discharge of the Middle Loup River at Dunning, Nebr.; for evaluating formulas and methods that could be used to compute sediment discharge at other locations in the Loup River basin; for modifying or developing, if necessary, formulas or methods that compute sediment discharge; for studying various sediment and hydraulic relationships; and for designing proposed river structures in the Loup River basin.

The idea that a structure could be designed so that it would produce sufficient turbulence to suspend the total sediment discharge of a stream prompted the development of the turbulence flume. Consideration was given at first to a modified Parshall flume and later to a straight-sided flume having vertical baffles or water jets in the floor. The flume having vertical baffles was selected as the most feasible design because it was independent of mechanical operation and would only affect the stream regime initially.

Model studies of the flume and subsequent preliminary designs for the prototype were made by the Civil Engineering Department, N. A. Christensen, Dean, and M. L. Albertson, Head of Fluid Mechanics Research, through the Research Foundation, Colorado 
Agricultural and Mechanical College, Fort Collins, Colo. P. C. Benedict, W. M. Borland, Thomas Maddock, and J. H. Honnold conferred frequently with representatives of the college during the model studies.

R. E. Oltman prepared the structural design and the construction plan and specifications for the prototype. The turbulence flume was constructed by the U. S. Geological Survey under the supervision of R. E. Oltman, who was succeeded by R. B. Vice. Permission was granted by the Nebraska Department of Roads and Irrigation for the construction of the flume beneath the bridge on State Route 2 at Dunning, Nebr.

The characteristics of the Middle Loup River at Dunning were especially favorable for the construction and operation of a turbulence flume. The stream is representative of other streams in the Loup River basin; the streamflow, which is derived mostly from ground water, remains fairly constant throughout the year; the stream bed consists almost entirely of sands; the stream channel for about 1,500 feet upstream from the flume site is straight and has a uniform and nearly constant cross section; the reach at Dunning was downstream from a proposed reservoir and upstream from a proposed diversion structure; and a U. S. Geological Survey stream-gaging station was already in operation at Dunning.

\section{PERSONNEL AND ACKNOWLEDGMENTS}

The part of the investigation by the Geological Survey was under the supervision of P. C. Benedict, regional engineer. Operation of the flume and of the selected river sections was planned by the personnel of the Geological Survey and by W. M. Borland and K. B. Schroeder, Hydrology Branch, and J. H. Honnold, O. H. Hansen, and J. F. Mayne, Region 7, of the Bureau of Reclamation. The collection of basic data was under the supervision of R. B. Vice, of the Geological Survey. E. F. Serr III, and later D. Q. Matejka, of the Geological Survey, were in charge of fieldwork. J. F. Mayne assigned engineers from the area office at Grand Island, Nebr., to help with fieldwork from August 17 to September 14, 1949. K. B. Schroeder supervised the Bureau of Reclamation personnel who computed some sediment discharges with the modified Einstein procedure. Mean daily and certain other water discharge data were furnished by $D$. D. Lewis, district engineer of the Geological Survey.

\section{BABIC INFORMATION}

In this part of the report, the turbulence flume and the six selected river sections are described, and the basic data are discussed. In addition, lateral distributions of stream velocity, of stream depth, 
and of measured suspended-sediment concentration as well as vertical distributions of velocity and of measured suspended sediment are shown. Water- and sediment-discharge measurements, water temperatures at times of measurements, and water-surface slopes are given in table 1. Data from cross-section soundings are given in table 2. Particle-size analyses of measured suspended sediment, bed material, and point-integrated samples are given in tables 3,4 , and 5 , respectively. Point velocities given in tables of particle-size analyses and shown in vertical distributions are nozzle velocities, which are computed from the time required to accumulate the sample, the volume of the sample, and the cross-sectional area of the nozzle opening.

\section{DEFINITIONS}

To help clarify a few general terms used in sedimentology and some specific terms used in this report, definitions and a brief discussion on various systems of nomenclature are given.

Sediment particles move by sliding or rolling, by skipping (saltation), and in suspension. Ordinarily, large heavy particles move by rolling or sliding, and small light particles move by saltation and in suspension. However, the mode of movement of any particle depends not only on the size of a particle but also on other physical characteristics of the particle and on the forces exerted on the particle. Therefore, many particles probably move by all the modes of transport rather than by only one mode. Quantitatively, the rate of sediment movement by each mode is probably fairly constant for any sustained flow condition.

Most existing sediment-discharge formulas have been devcloped for computing only some part of the total sediment discharge or only the discharge of the sediment that is moved by one of the modes of transport. As a result, various systems of nomenclature have been used to distinguish between the parts of the total sediment discharge. Usually, the total sediment load is divided into bed load and suspended load, and the saltation load is considered to be either insignificant or a part of the bed load and the suspended load. Bed load, sometimes called surface creep, is the moving sediment that is in contact with the bed or that is very near the bed; thus, bed load includes all sliding and rolling sediment and some skipping sediment. The suspended load includes all suspended sediment and some skipping sediment.

Most bed-load formulas are based on the theory that particles are set in motion if the forces exerted on the particles are sufficient to lift the particles from the bed and (or) to overcome the frictional resistance between the particles and the bed. However, the concept of a shear or tractive force created by the component of fluid weight in the direction of flow has been adopted as a measure of the forces 
by some investigators, whereas physical characteristics of the boundary and various flow parameters have been considered to be the measure by other investigators.

Suspended-sediment formulas are based on the turbulence-suspension theory, which explains the phenomena of sediment suspension by fluid turbulence.

Einstein (1950) has divided the total sediment load into wash load and bed-material load. Wash load is composed of the particles that, for given hydraulic conditions, are not in significant quantities in the bed. This load is washed through the channel in nearly continuous suspension. Bed-material load is the part of the load that is picked up from the bed and that is readily returned to the bed. The term "bed-material load" does not imply a mode of movement, for bedmaterial load is conveyed as both bed load and suspended load. Einstein has defined bed load as the sediment that moves through the bed layer, a layer 2 grain diameters thick, above the nonmoving bed.

The total sediment load may be divided also into measured sediment discharge and unmeasured sediment discharge. Neither of these discharges is intended to pertain to any particular mode of movement; however, measured sediment discharge is usually composed of only suspended sediment and, therefore, is often called measured suspendedsediment load. Measured sediment discharge is computed from the measured suspended-sediment concentration. Because equipment currently available for sampling suspended sediment cannot collect water-sediment mixture close to the bed, not all the suspended sediment is represented in the samples. Unmeasured sediment discharge is the difference between the total sediment discharge and the measured sediment discharge;it includes all sliding or rolling, usually all skipping, and some suspended-sediment particles-in other words, all bed-load discharge and some suspended-sediment discharge.

Some of the specific terms in this report are defined as follows:

Fluvial sediment is sediment that is transported by, is suspended in, or has been deposited from water.

Water discharge is the rate of flow of a stream and includes the fluvial sediment and dissolved solids that are transported in the water.

Suspended sediment is the sediment that at any given time is moving in suspension in water and is maintained in suspension by the upward components of turbulent currents or by colloidal suspension.

Depth-integrated sediment sample is a water-sediment mixture collected in a sampler that moves vertically at a constant transit rate and that admits the mixture at a velocity about equal to the stream velocity at every point of its travel. Depth-integrating samplers now in general use are the U.S. DH-48, U. S. D-43, U. S. D-49, and U. S. 
P-46; the U. S. P-46 sampler is designed for point integrating but can be used for depth integrating. These samplers normally collect water-sediment mixture only from the surface to about $0.3,0.4,0.4$, and 0.4 foot, respectively, above the stream bed.

Point-integrated sediment sample is a water-sediment mixture accumulated continuously during a given period in a sampler that is held as nearly as possible at a fixed point and that admits the watersediment mixture at a velocity about equal to the instantaneous stream velocity at the point. The U. S. P-46 and the U. S. DH-48 are now in general use as point-integrating samplers; the U. S. DH-48 sampler is designed for depth integrating but, with certain physical modification and (or) sampling techniques, can be used for point integrating.

Measured suspended sediment is the part of the total quantity of suspended sediment that is represented by samples collected with suspended-sediment samplers. A sediment sample normally represents the suspended sediment for a limited depth and a limited width of the cross section. For a depth-integrated sample, the limited depth is from the water surface to the lowest point of collection. Samples from several verticals are required for representation across the entire width.

Sediment concentration is the ratio of the weight of sediment to the weight of water-sediment mixture, in parts per million. A part per million is a unit weight of sediment in a million unit weights of watersediment mixture.

Mean concentration is a composite of the concentrations at different points of flow and is obtained by weighting the concentration at each point with the stream velocity at that point. Therefore, the concentration of a depth-integrated sample or samples is a mean concentration.

Measured suspended-sediment concentration is the mean concentration of the measured suspended sediment.

Sampling zone or sampled zone is that part of a cross section through which the measured suspended sediment moves. For this report, sampling zone refers to the entire width.

Measured suspended-sediment discharge or load is a rate of sediment movement and is computed as the product of the measured suspended-sediment concentration, the total water discharge, and a constant for converting the units to a weight per unit time, generally tons per day. Because the total water discharge is used in the computation, the measured suspended-sediment discharge includes not only the discharge of suspended sediment in the sampled zone but also a part of the discharge of suspended sediment in the unsampled zone. 
Suspended-sediment discharge measurement is a determination of suspended-sediment discharge that is made from sufficient suspendedsediment samples at a cross section to define the mean concentration within the sampled zone and from an adequately determined water discharge.

Bed load is the sediment that moves along in essentially continuous contact with the stream bed.

Bed-load discharge is the weight of bed load passing a section in a unit of time and is generally expressed in tons per day.

Bed-material discharge or load is the part of the total sediment load consisting of particles whose sizes are the same as those present in significant quantities in the bed. In this report, bed-material load includes all material coarser than the largest standard separation size (see headings on table 4) at which no more than 10 percent of the bed material is finer.

Wash load is the part of the total sediment load consisting of particles whose sizes are finer than those present in significant quantities in the bed. In this report, wash load includes all sizes finer than the largest standard separation size (see headings on table 4) at which no more than 10 percent of the bed material is finer.

Total sediment concentration is the concentration of all the sediment passing a given section in a stream.

Total sediment discharge or load is the weight of all the sediment passing a section in a unit time. It is also a product of the total sediment concentration, the total water discharge, and a constant for converting the units to a weight per unit time-generally tons per day.

Unmeasured sediment discharge or load is the difference between total sediment discharge and the measured suspended-sediment discharge. More particularly, it is the sum of the bed-load discharge and the product of the water discharge in the unsampled zone, a constant for converting the units to a weight per unit time, and the difference between the mean concentrations of suspended sediment in the unsampled and sampled zones.

Geometric mean size is the size that is computed as the square root of the product of the upper and lower limits of the size range. In this report the range of the smallest particle sizes was arbitrarily assumed to be $0.002-0.062$ millimeter.

Effective width is the width determined by applying an appropriate horizontal angle correction to the width rather than to the velocity or discharge. The effective width of a channel is the sum of the effective widths for each section of a water-discharge measurement. It is also the length of a discontinuous line that crosses the channel and that is normal to the direction of flow at every point on the line. 
Effective area is the sum of the products of the effective width and measured depth for each section of a water-discharge measurement.

\section{MIDDLE LOUP RIVER}

The Middle Loup River upstream and for some distance downstream from Dunning is in the sandhills region of north-central Nebraska. The sandhills are underlain by the Ogallala formation of Tertiary age and are mantled by loess and dune sand to a depth that in some places exceeds 100 feet. The topography is formed by northwest-trending sand dunes, which are stabilized by grass cover. The vertical distance from the crests to the low places between the dunes is about 50 feet. The valley floor of the river upstream from Dunning is generally about half a mile wide and is about 80 feet lower than the uplands. The valley floor is composed of sand that was mostly deposited by the stream and that is topped in some places with a thin layer of soil. Grass meadows or brush and trees border the channel, which is defined by low banks. Meanders are not well developed, although bank erosion is prevalent and is the source of most of the sediment load; however, some sections of the channel near Dunning have been stabilized by brush riprap, which generally has been effective in protecting the banks from scour. The drainage area of the river upstream from Dunning is approximately 1,760 square miles, of which about 80 square miles contributes directly to surface runoff (U. S. Geol. Survey, 1954). Flow is mainly derived from ground-water accretion along the entire channel. During the period October 1, 1945, through September 30, 1952, at Dunning, Nebr., the maximum daily discharge was $630 \mathrm{cfs}$ (cubic feet per second), the minimum was $100 \mathrm{cfs}$, and the mean was $381 \mathrm{cfs}$. The Dismal River (fig. 1), which flows from the west, enters the Middle Loup River about $1 \frac{1}{2}$ miles east of Dunning.

\section{TURBOLENCE FLUME}

The turbulence flume is under the bridge on State Route 2 at Dunning, Nebr., about 1,200 feet downstream from the gaging station. (See fig. 2.) Benedict, Albertson, and Matejka (1955) gave the following physical description of the prototype turbulence flume:

The turbulence flume is a structure for inducing turbulence sufficient to suspend substantially the total sediment load of a stream. The flume consists of a series of 1-ft by 2 -ft movable baffles, one continuous 0.5 -ft permanent baffle, and a 6 -in. by 16-in. wooden baffle (measuring sill) attached to a reinforced-concrete slab $82 \mathrm{ft}$ wide and $38 \mathrm{ft}$ long. The $1-\mathrm{ft}$ by $2 \mathrm{ft}$ baffles are galvanized steel sheets supported by two round rods inserted in pipe sockets embedded in the concrete slab. The permanent baffle, a 6 -in. by 4 -in. angle, and the wooden measuring sill are bolted to the concrete slab.

The concrete slab, which is the floor of the flume, is supported at each end by interlocking sheet-steel piling driven to a depth of $10 \mathrm{ft}$. The top of the slab is $468443-59-2$ 
just below the average elevation of the stream bed at a discharge of approximatery $400 \mathrm{cu} \mathrm{ft}$ per sec. The wooden end sill, which is bolted to the downstream end of the slab, was designed to produce a reverse roller to prevent scour of the stream bed immediately downstream from the flume.

*** Walkways were installed immediately below the upstream edge of the slab and immediately downstream from the measuring sill to simplify the collection of depth-integrated sediment samples. $* * *$

The flume operation during the test period was considered satisfactory except for the intermittent deposition of sand on the measuring sill. This deposition indicated that the turbulent energy was insufficient to suspend the total sediment load during maximum dune movement through the flume. On the basis of the results of the model studies, the first two rows of baffles at the upstream end of the flume were raised $0.5 \mathrm{ft}$ on March 29, 1951.

Plate 1 and figure 3 show the placement of the baffles, measuring sill, end sill, and walkways.

Water-surface profiles along both banks on July 8, 1952, (fig. 4) show that the presence of the flume in the channel affects the flow only locally in a reach of about 300 feet upstream and 300 feet downstream from the flume. Beyond this reach the stream conditions are about the same as they were before the flume was installed. Ordinarily, the fall at the right side of the flume is greater than that at the left, and it is associated with a greater discharge per foot of width. Upstream from the flume, the thalweg of the flow follows the right bank. Downstream, the left bank is overhung with brush, and the channel bends to the right. Because the tendency of the flow is to concentrate on the right side of the flume, flow at the left side sometimes has velocities that are insufficient for suspending the particles, and the baffles become partly covered; however, the measuring sill remains clean most of the time. An average profile of the stream probably would show backwater upstream from the flume, an increased slope through the flume (associated with increased velocity and turbulence), and a flatter than natural slope downstream from the end sill of the flume (probably resulting from a regain in elevation head with a decrease in velocity head).

\section{SECTION C}

Section $\mathrm{C}$ is at the upstream side of the turbulence flume. (See fig. 2, and pl. 2.) Streamflow measurements were made, and suspended-sediment samples were collected at section $\mathrm{C}$ to define the measured suspended-sediment concentration and discharge entering the flume. These measurements were usually made from a walkway that spanned the 82-foot width of the river. Particle-size analyses of measured suspended sediment show that about 88 percent of the sediment is coarser than 0.062 millimeter and that sieve diameters of about half of the total sands are between 0.125 and 0.25 millimeter. 


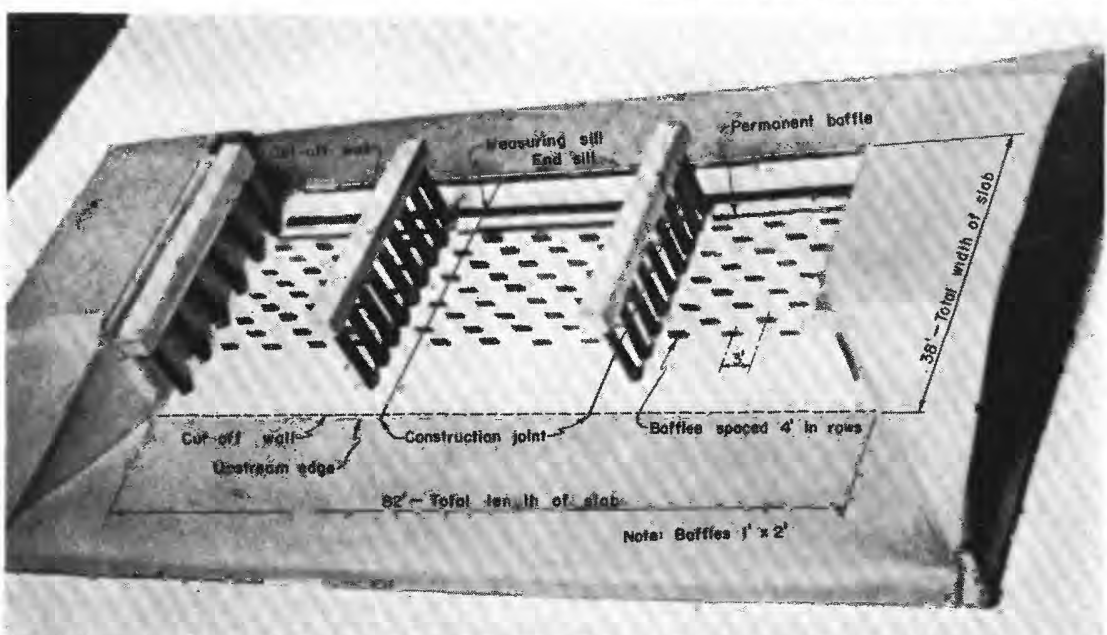

SKELETON MODEL OF PROTOTYPE FLUME

(Benedict, Albertson, and Matejka, 1955) 


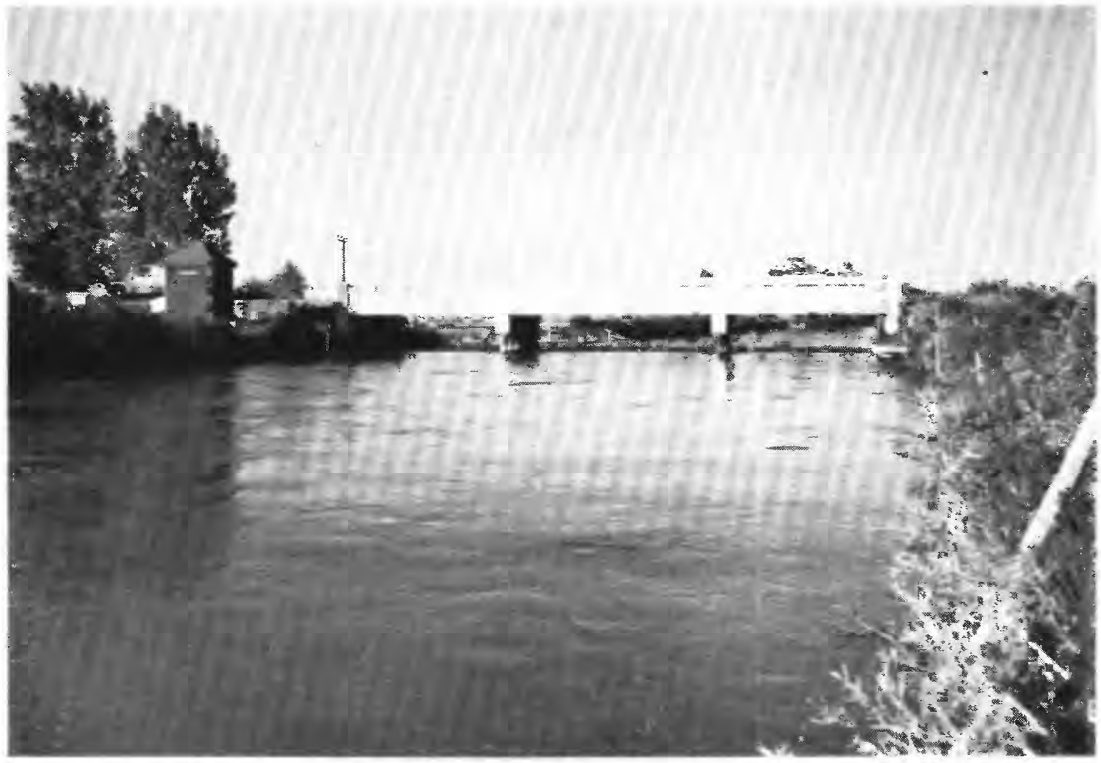

A. APPROACH TO THE TURBULENCE FLUME

The water-stage recorder for the turbulence flume is at the left. July 14, 1953, water discharge about 350 efs.

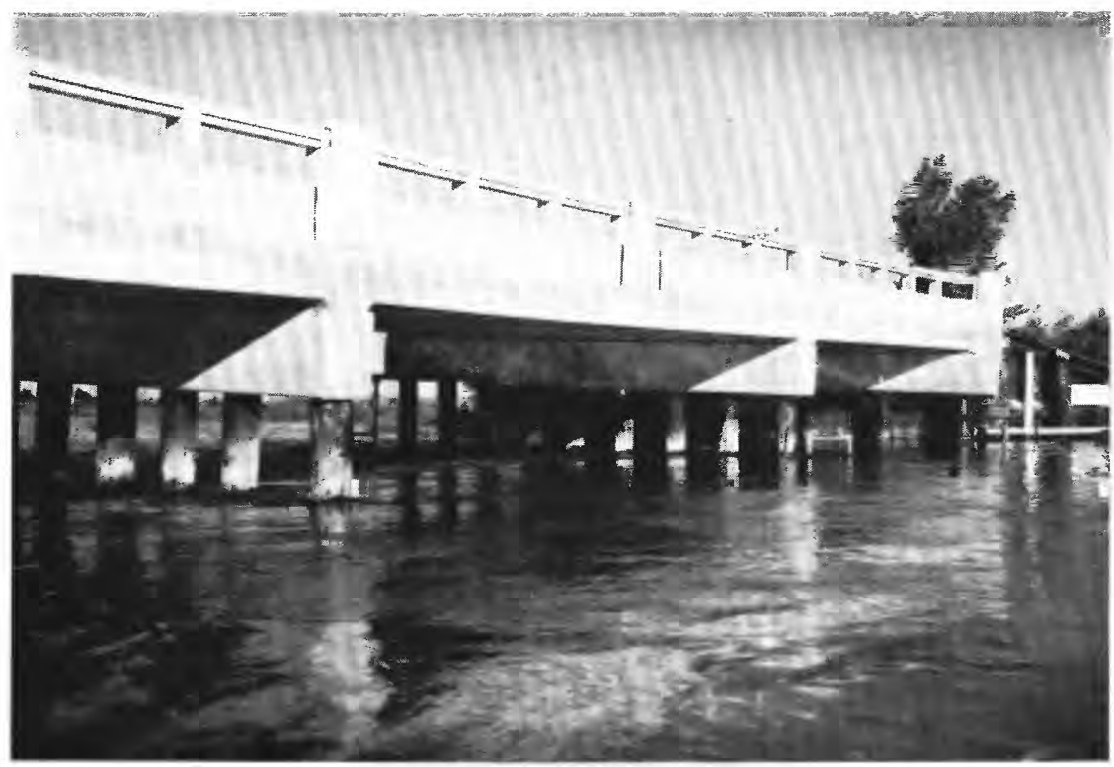

$B$. SECTION G FROM THE LEFT BANK

The apparent fall through the turbulence flume is partly from superelevation of downstream side of bridge. July 14, 1953, water discharge about $350 \mathrm{cfs}$. 


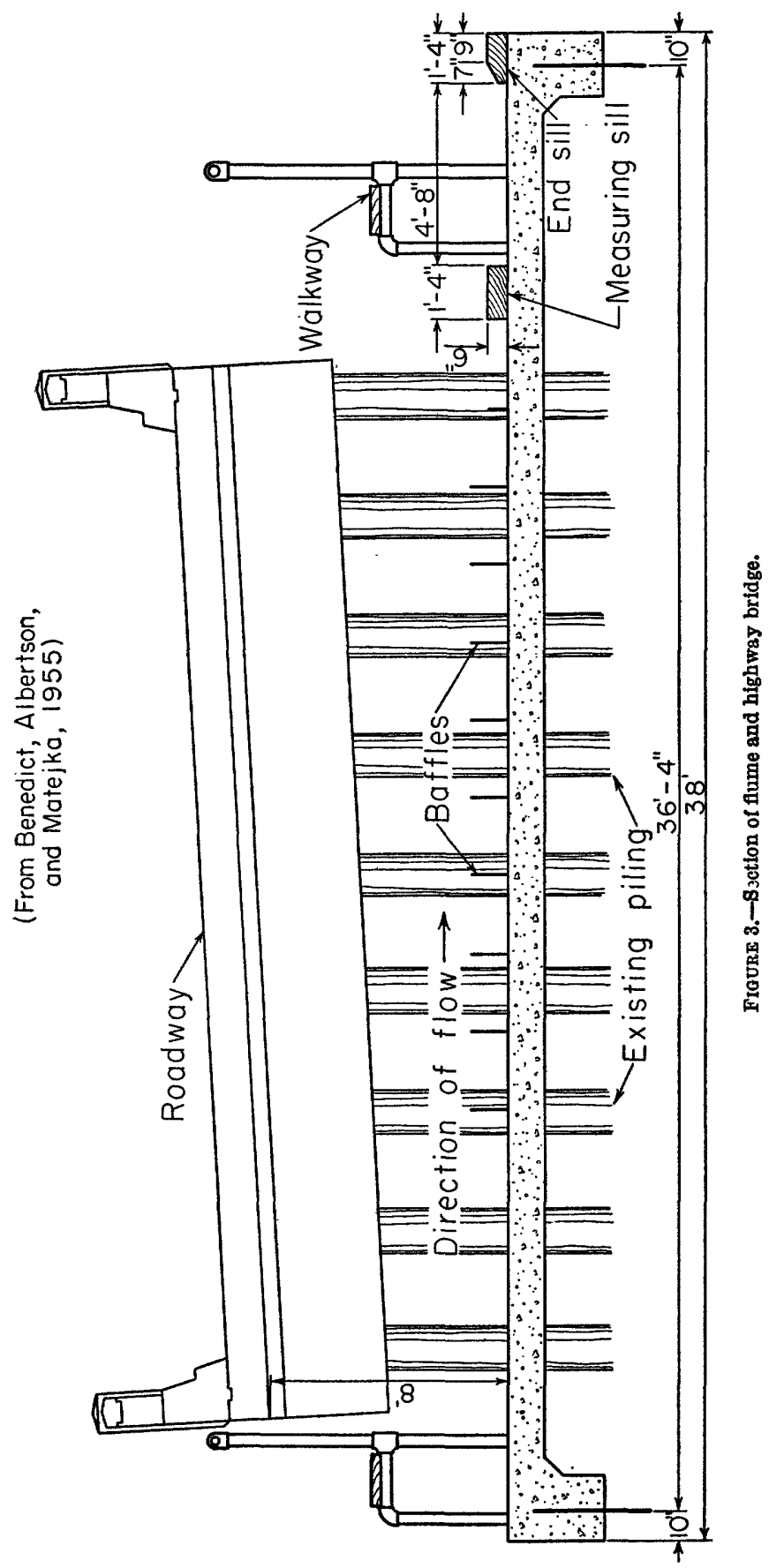


14 SEDIMENT TRANSPORTATION, MIDDLE LOUP RIVER, NEBR.

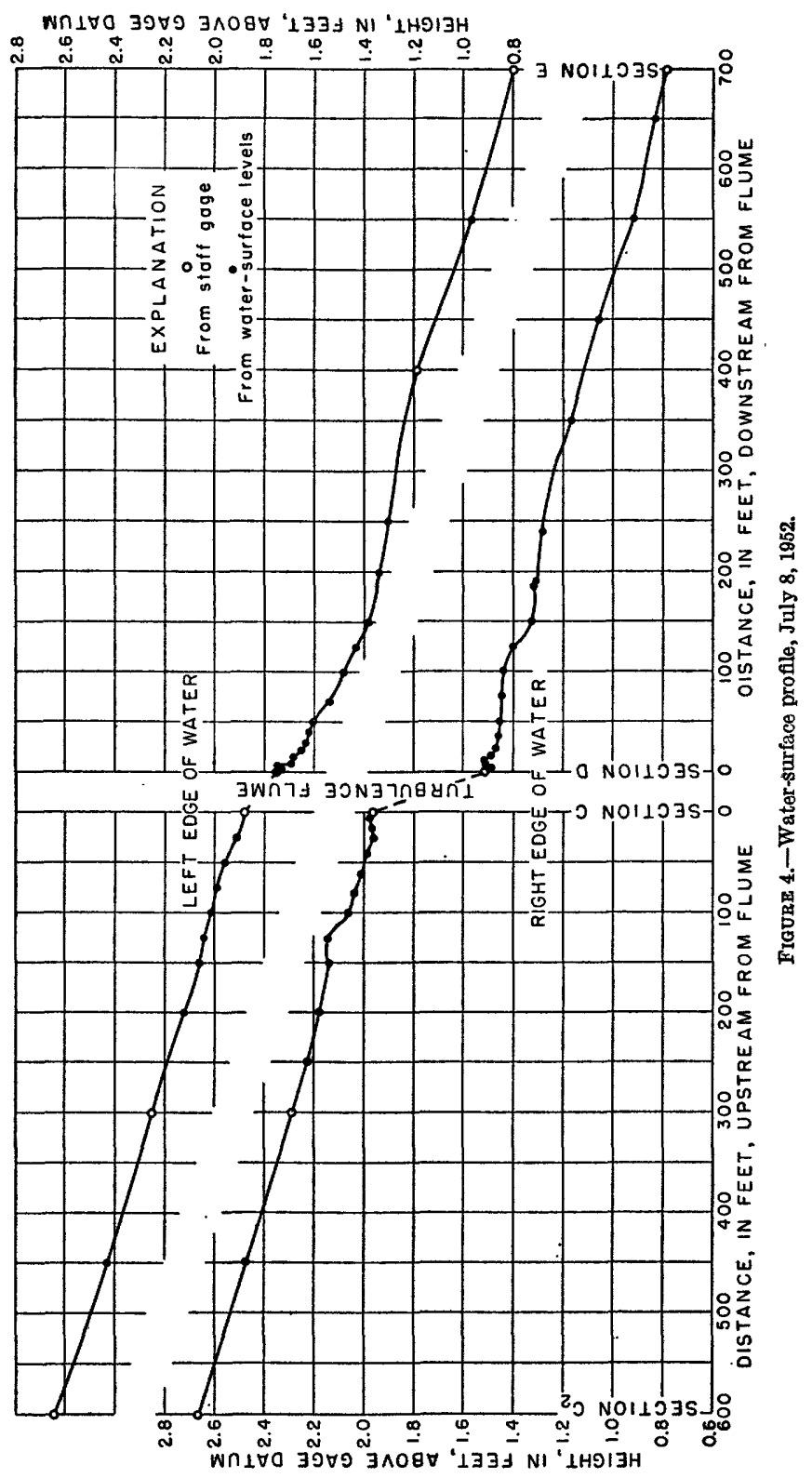


Also, only a very small percentage of the sediment is coarser than 0.50 millimeter.

Some bed-material samples were collected at or very near section C. The particle-size analyses of these samples show that the median sieve diameter is in the 0.25 - to 0.50 -millimeter size range. The bed-material size distribution and the measured suspended-sediment size distribution for two different medium flows are shown in figure 5 .

The lateral distributions of depth, stream velocity, and measured suspended-sediment concentration varied with dune movement into the flume. Figure 6 shows lateral distributions for 3 different days.

Vertical distributions of the suspended sediment and flow entering the flume are defined from point-integrated samples collected at section $C$. These distributions indicate slightly more turbulence at section $\mathrm{C}$ than at the selected river sections; $z_{1}$ values (see "Variations in $z_{1}$ ") are lower and vertical-velocity distributions are more uniform at section $\mathrm{C}$ than at section $\mathrm{B}$, which is probably the most turbulent of the selected river sections. Figure 7 shows the vertical distributions of velocity, suspended-sediment concentration, and percentage of particles coarser than 0.25 millimeter at section C on July 18, 1950.

Both a permanent water-stage recorder and a continuous water- and air-temperature recorder are housed together about 15 feet upstream from section $\mathrm{C}$ (pl. 2A). Daily maximum and minimum water temperatures are not given here but are published annually in the U. S. Geological Survey Water-Supply Papers of the series, Quality of Surface Waters of the United States. A staff gage on the left bank serves as the outside gage for the recorder and is also used in association with staff gages on the right bank at sections $C$ and $D$ to establish the fall through the flume.

Measurements were begun at section $\mathrm{C}$ on the assumption that possibly the difference in concurrently measured suspended-sediment discharges at this section and at section $D$ would be representative of the unmeasured sediment discharge of an average reach of the stream. However, early measurements indicated that this assumption was generally invalid because measured suspended-sediment concentrations and discharges at section $\mathrm{C}$ were not representative of those at unconfined river sections. Suspended-sediment discharges at section $\mathbf{C}$ were generally comparable to those at section $B$, a very narrow confined section, and were often greater than those at sections $A$ and $E$, unconfined sections, by 100-200 tons per day.

\section{SECTION D}

Section $\mathrm{D}$ is at the downstream side of the measuring sill of the turbulence flume (fig. 2 and pl. $3 A$ ). From the walkway spanning the section, samples normally are collected with a U. S. DH-48 hand 

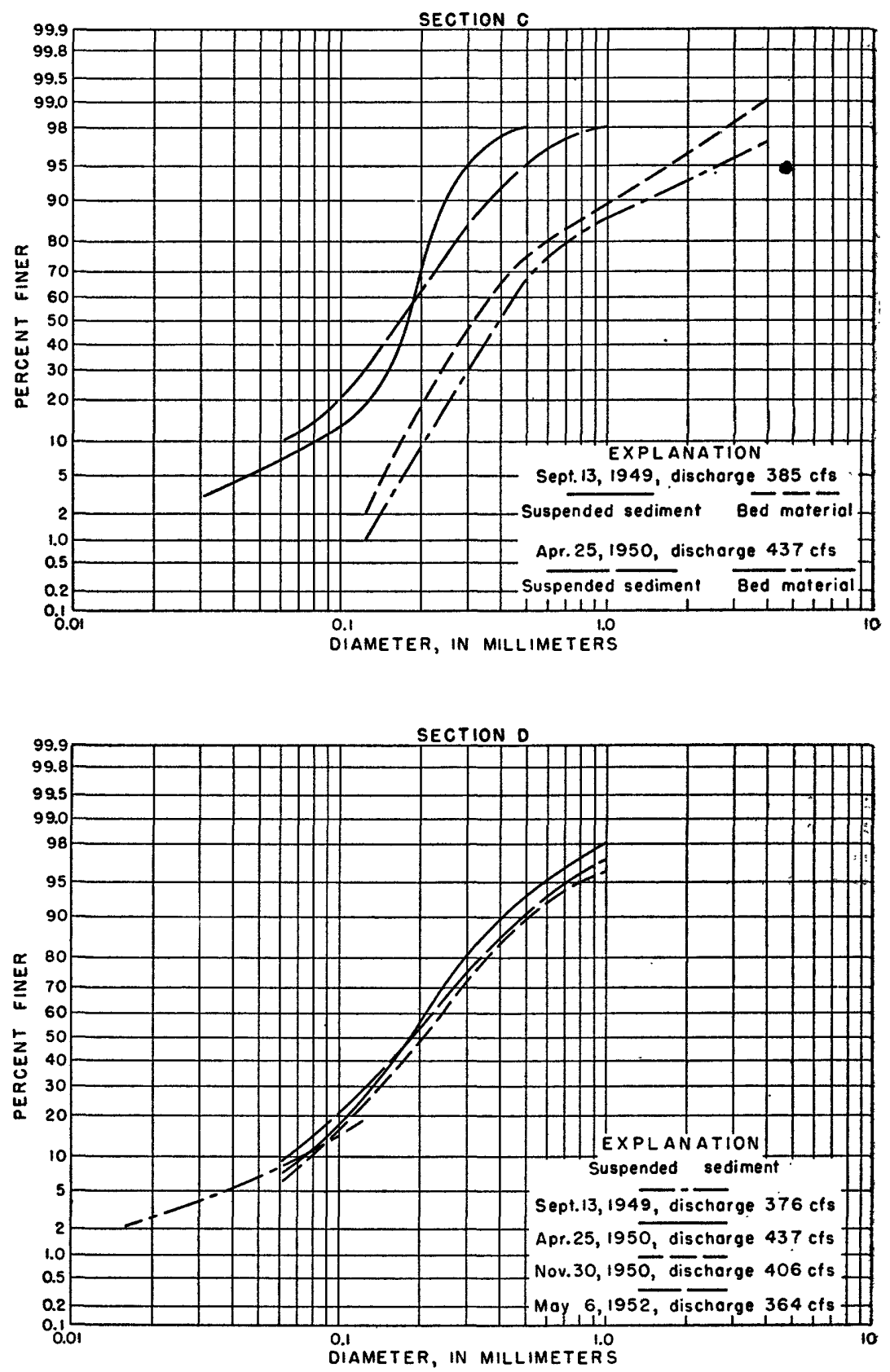

Figuae 5.-Particle-size distributions of measured suspended sediment and bed material, sections $\mathbf{C}$ and $\mathbf{D}$. 


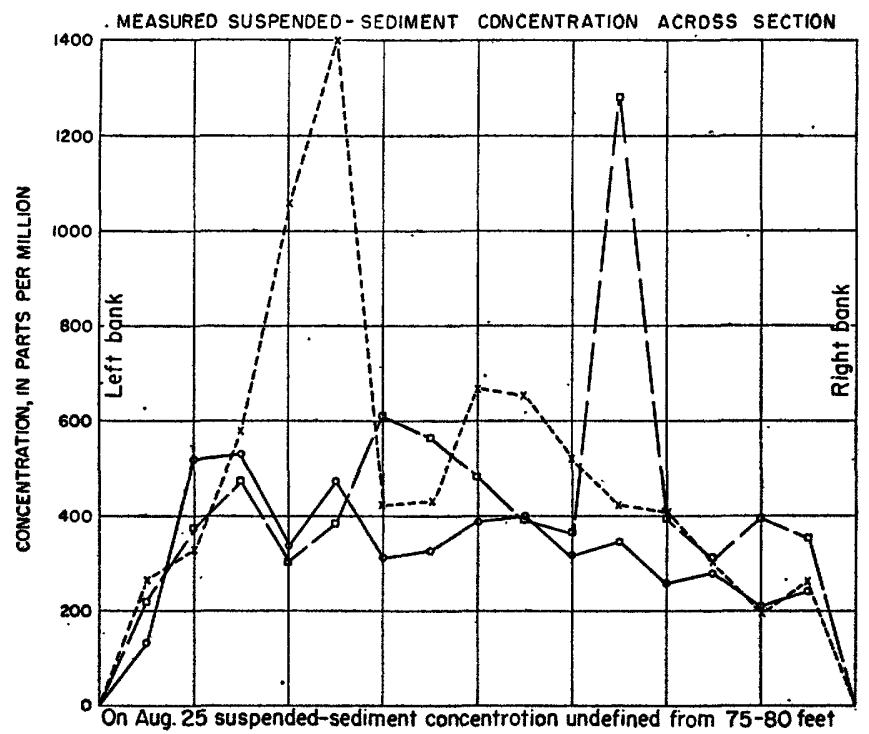

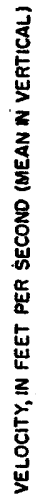
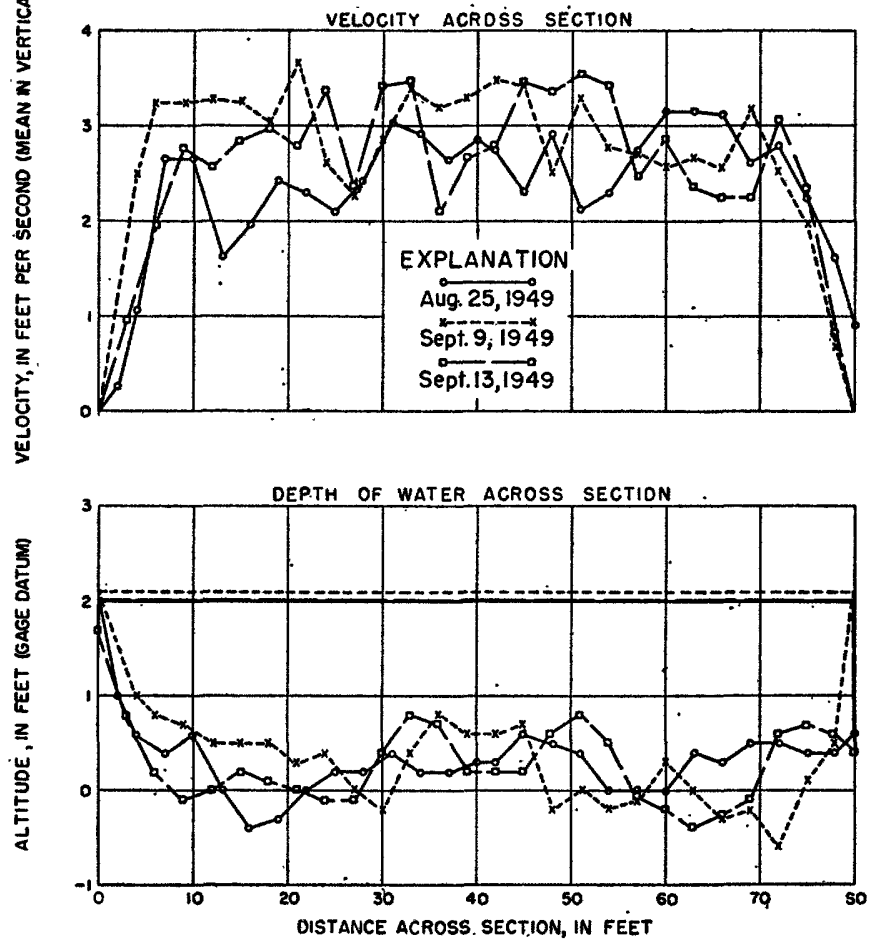

Figure 6.-Lateral distributions of depth, stream velocity, and measured suspendedsediment concentration, section $\mathrm{C}$. 


\section{EXPLANATION}

Concentration, in parts per million

Velocity, in feet per second

Percent coarser than $0.25 \mathrm{~mm}$
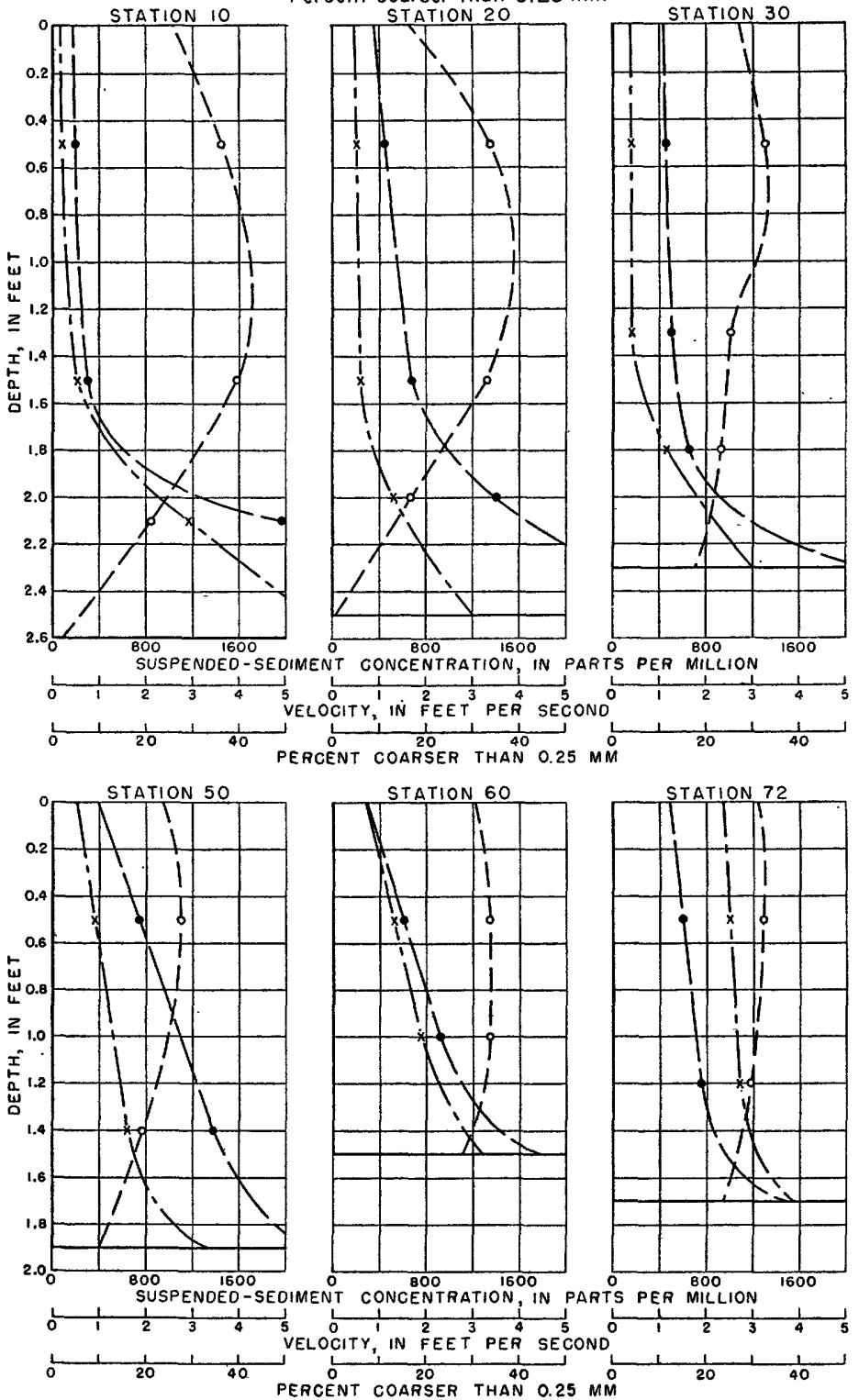

Figure 7.-Vertical distributions of suspended-sediment concentration, velocity, and percent coarser than $0.25 \mathrm{~mm}$, section $\mathrm{C}$, July 18, 1950. 


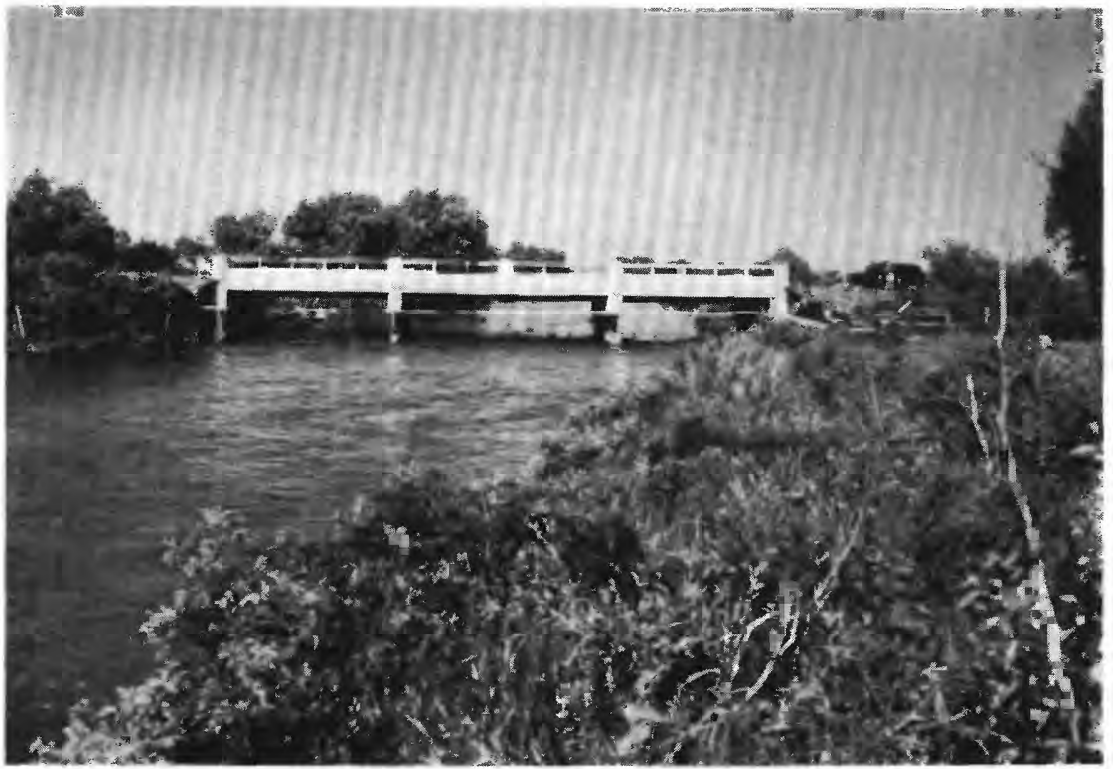

A. SECTION D FROM THE LEFT BANK

July 14, 1953, water discharge about $350 \mathrm{cfs}$.

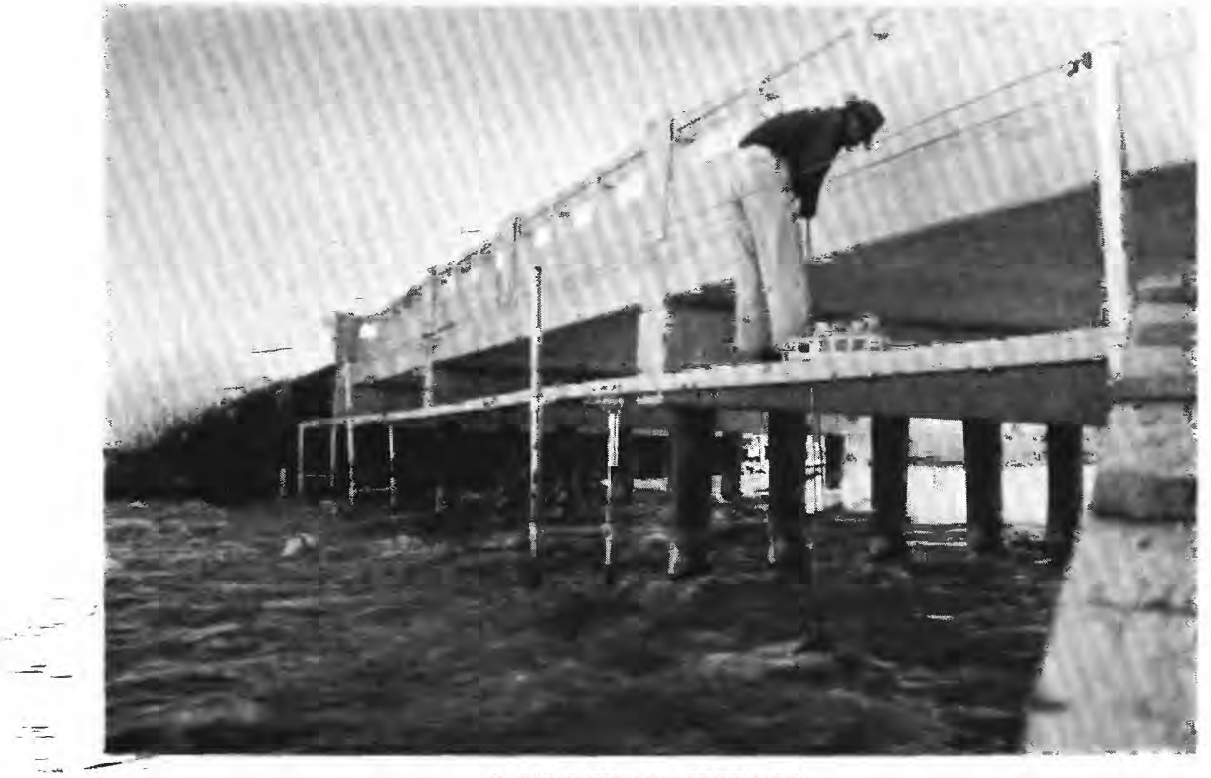

B. SAMPLING AT SECTION D

Note the guide bracket for the sediment sampler and the walkway which is raised to the winter position. April 9, 1952, water discharge about 450 cfs. 


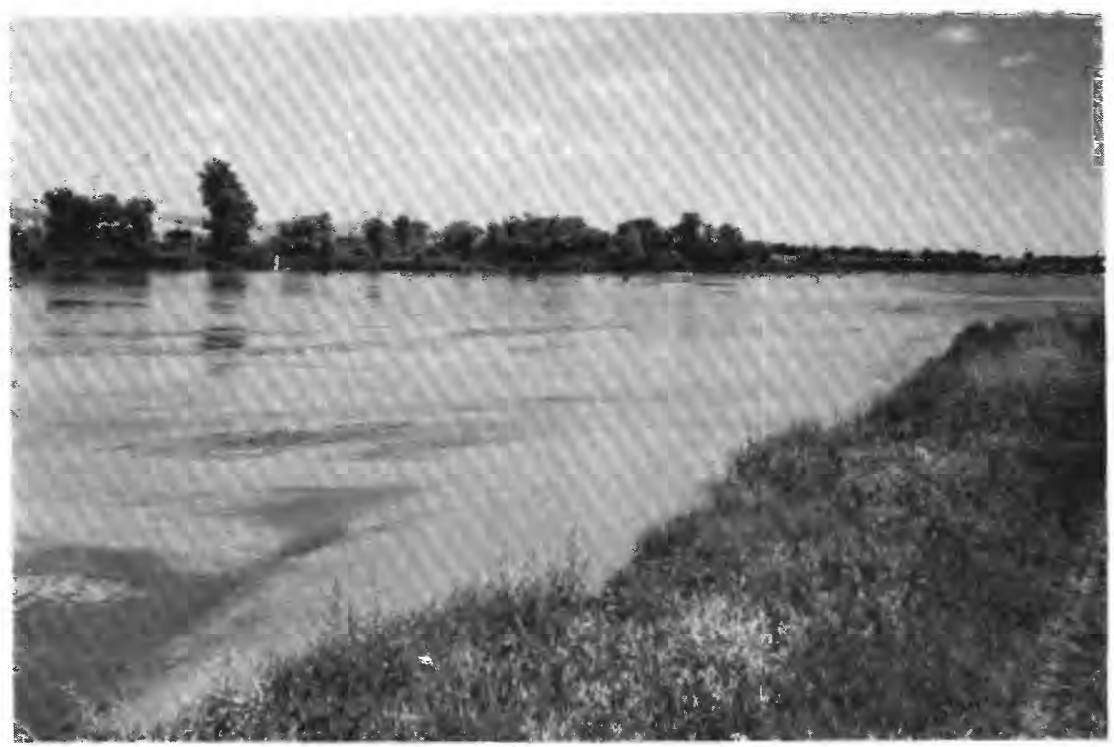

A. SECTION A FROM THE RIGHT BANK

The tallest tree is adjacent to the left edge of the section. July 14, 1953, water discharge about $350 \mathrm{cfs}$.

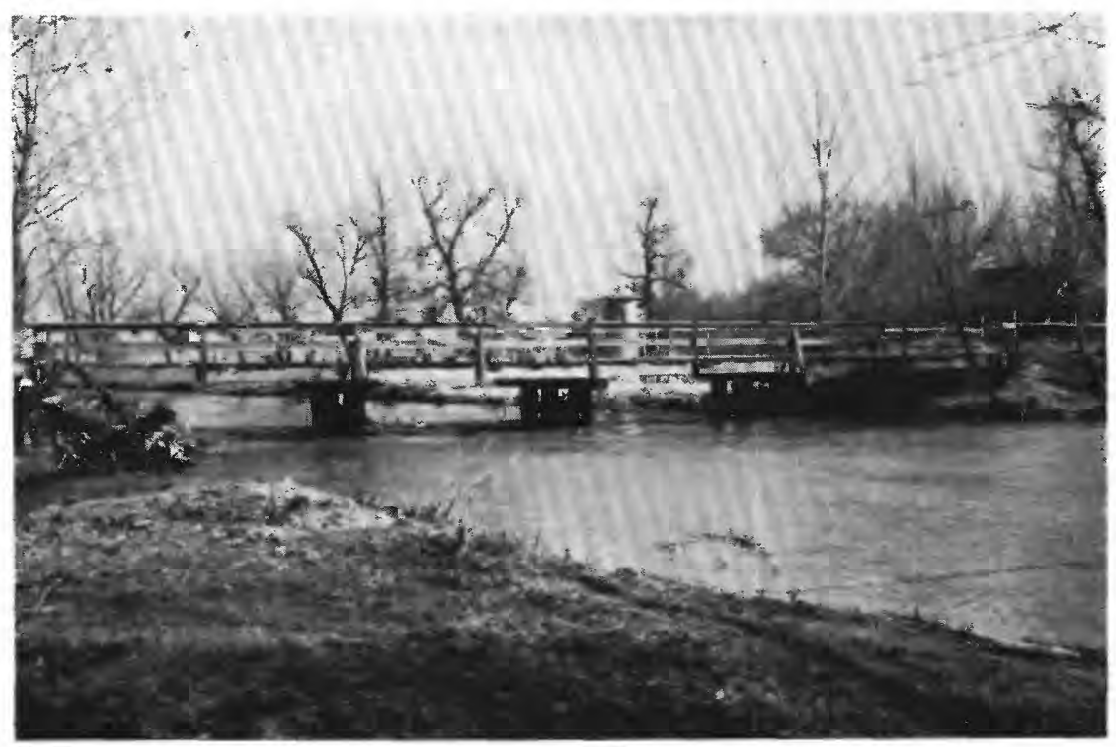

B. SECTION B FROM THE LEFT BANK

The water-stage recorder for the gaging station is on the right bank behind the bridge. The ditch at the left connects with a pond and contributes no inflow. April 9, 1952, water discharge about $450 \mathrm{cfs}$. 
sampler. (See pl. 3B.) A portable bracket, which can be hooked over the measuring sill, guides the sampler so that, when the sampler is moved vertically along the bracket, the nozzle of the sampler traverses the entire depth of flow from the water surface down to the top of the measuring sill. As long as the measuring sill is free of sand deposits, all the sediment passing over the sill can be sampled regardless of the vertical distribution of sediment. Thus, concentrations determined from depth-integrated samples represent the total sediment concentration, which is used in computing the total sediment discharge.

Two different types of samples were collected at section D. Daily samples consisted of depth-integrated samples collected at stations $10,30,50$, and 70 ; cross-section samples consisted of depth-integrated samples collected at 15 verticals or more, spaced either at equal increments of width or according to water discharge. The daily samples were collected once or twice a day by a local observer, and daily samples and cross-section samples were collected periodically by engineers. Concentrations from the daily samples were used to define a continuous concentration curve from which a time-weighted mean concentration for each day was determined. However, because the time-weighted mean concentrations were sometimes unrepresentative of the cross section as a whole, they were corrected by using a determined relation between the cross-section samples and the daily samples. Forty-four ratios of the concentrations from daily samples to the concentrations from cross-section samples during part of the 1950 water year and all the 1951 and 1952 water years averaged 1.03 and ranged from 0.72 to 1.61 .

The relation between the concentrations of cross-section samples and daily samples fluctuates. The relation does not seem to be affected by any of the common flow parameters; but it is, of course, affected by variations in the lateral distribution of sediment in the cross section, which is in turn affected by dune movement into the flume. An analysis of data collected on June 27, 1951, (Benedict, Albertson, and Matejka, 1955) indicates the extent of the variations of daily sample concentrations with time. Concentrations from depth-integrated sediment samples collected at 5 -minute intervals over a 4-hour period at the 4 daily sampling stations indicate that the concentration of any sample at any time might vary as much as \pm 83.5 percent from the true mean for the vertical. Also, the concentration determined from 1 bottle at each of the 4 stations might vary from the average concentration as much as \pm 25 percent, and a concentration determined from 2 bottles at each of the 4 stations might vary from the average concentration as much as \pm 19 percent. Two bottles at each of the 
four verticals are normally collected to obtain daily sample concentrations.

Records of sediment loads (total load) passing section $\mathbf{D}$ are published in a continuing series of water-supply papers entitled, Quality of Surface Waters of the United States. The published daily loads are computed from daily mean water discharges and from daily mean concentrations that are corrected to represent cross-section concentrations. Monthly and annual sediment loads passing section $\mathbf{D}$ during the period March 22, 1950, through September 30,1952, are given in table 6. During most of the year, monthly loads are fairly constant, although they are usually highest in late winter and early spring.

Data from measurements of water and suspended-sediment discharges indicate that $Q_{t s}$, the total sediment discharge, varies about

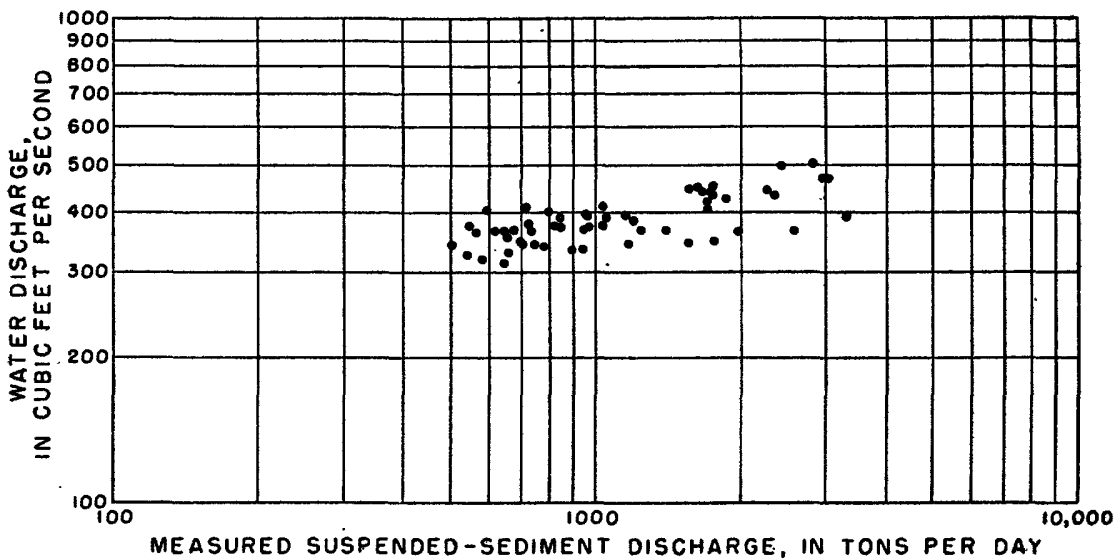

Figure 8.-Sediment-transport curve for section $D$ at the turbulence flume.

as the cube of $Q_{w}$, the water discharge, $\left(Q_{t s}=C_{1} Q_{w}{ }^{3}\right)$; however, the relationship is not well defined. (See fig. 8.)

Size analyses of depth-integrated samples represent the size distribution of the total load of the stream and show that about 90 percent of the sediment is coarser than 0.062 millimeter and that about 35 percent of the total is in the 0.125- to 0.25 -millimeter size range. Figure 5 shows the size distribution of the material passing the flume on 4 different days of medium water discharge. The percentage of suspended sediment in individual size ranges is fairly constant except possibly at relatively high and low concentrations (fig. 9).

Generally at section $\mathrm{D}$, the depth decreases and the velocity of flow increases from the left to the right bank. However, the measured suspended-sediment concentration follows a random pattern; the concentrations have a tendency to be highest in the center bay of the 

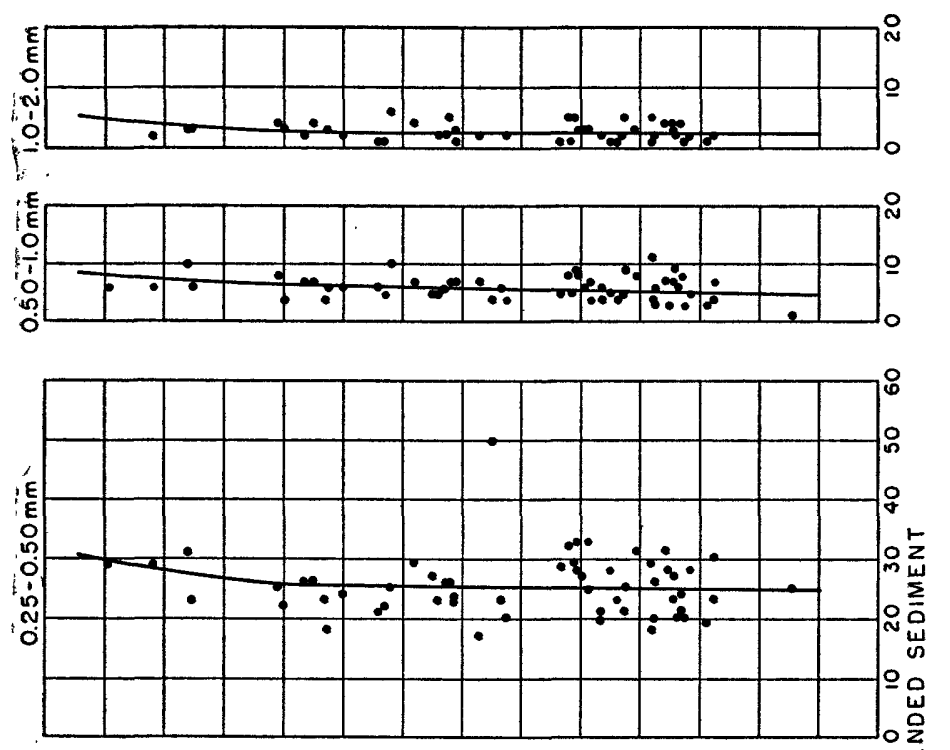

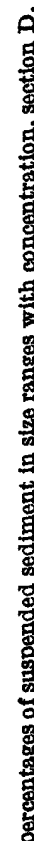
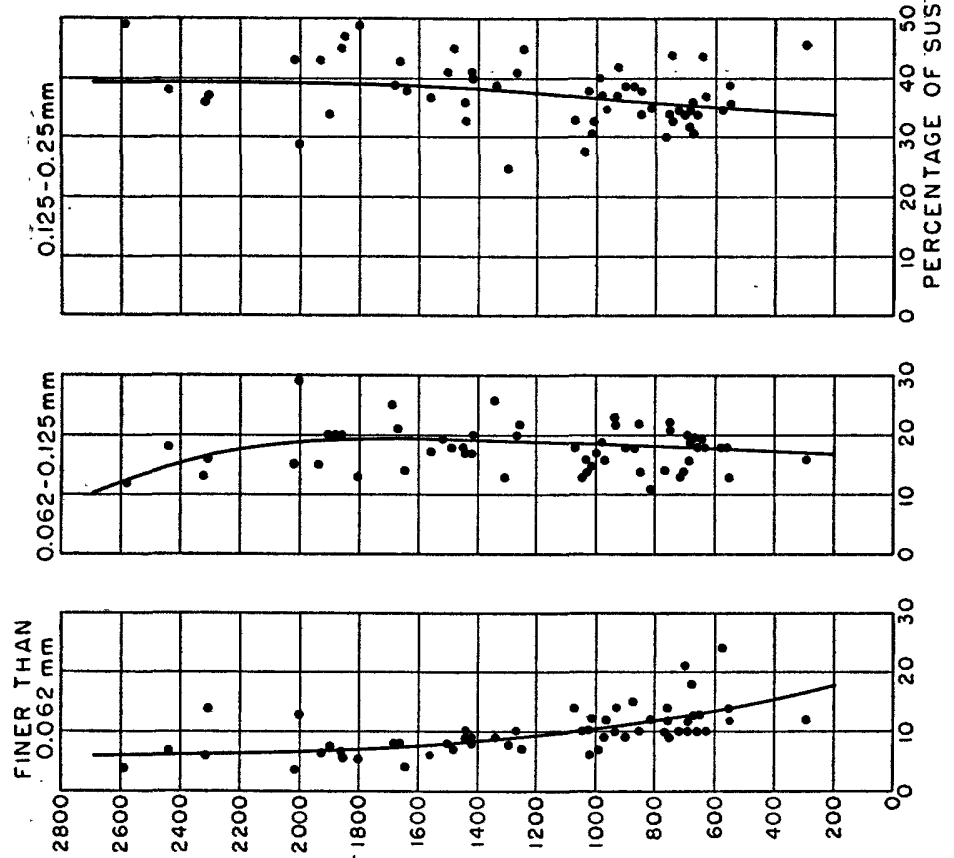

离

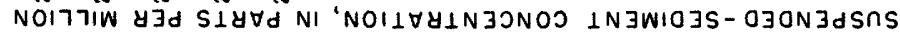



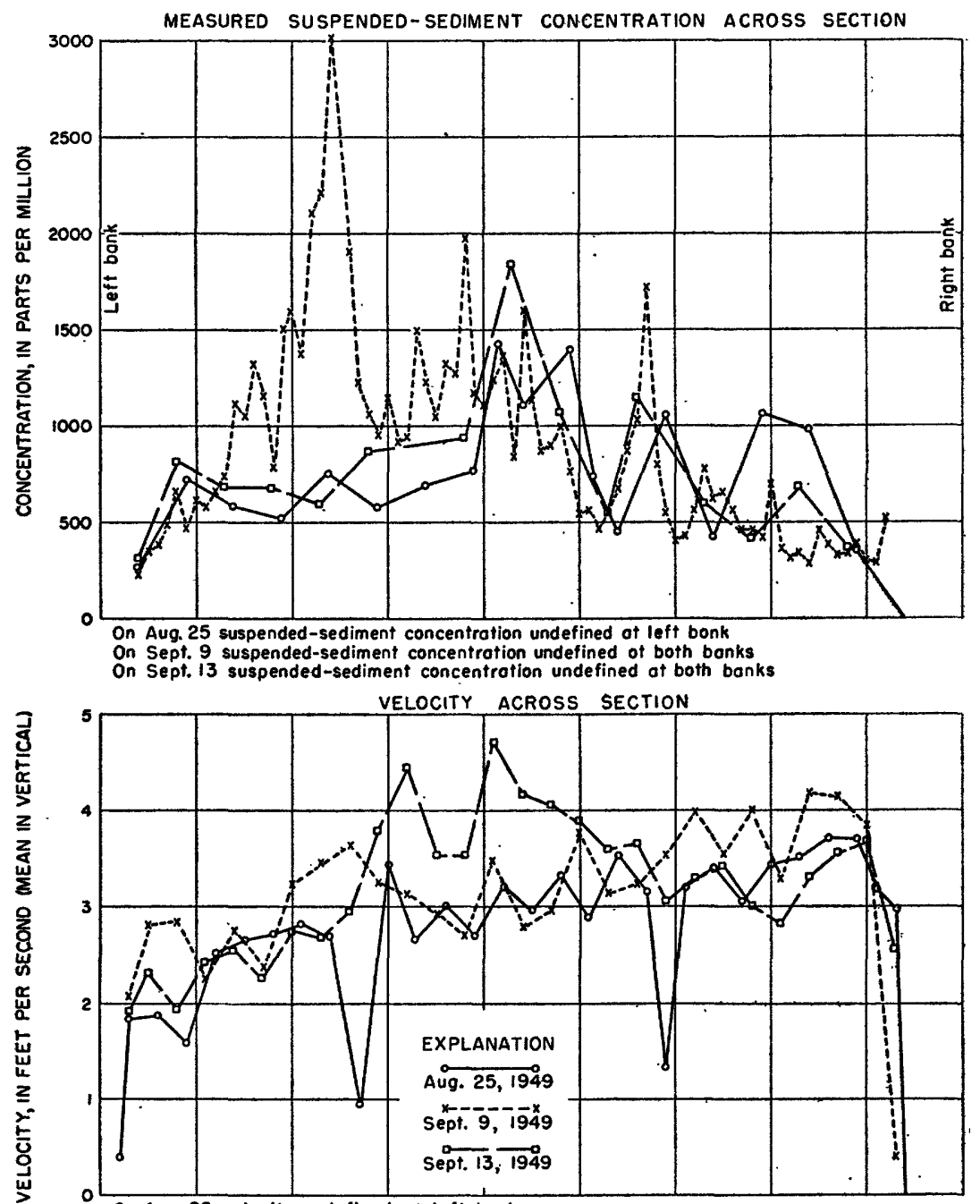

On Aug. 25 velocity undefined of left bank

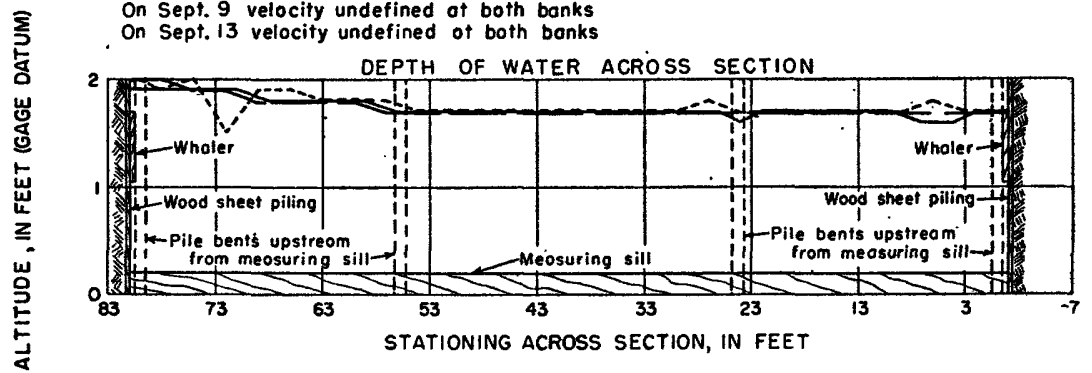

Froure 10.-Lateral distributions of depth, stream velocity, and measured suspended-sediment concentration, section $\mathrm{D}$. 
flume. Lateral distributions on 3 days are shown in figure 10. The lateral distribution of sediment depends largely on dune movement into the flume. Consequently, concentrations are high in one part of the flume at one time and in another part at another time. A description of the dune movement into the flume is given by Benedict, Albertson, and Matejka (1955).

The crest of the large dunes when approaching the flume would, at times, be at an elevation higher then the top of the baffle plates in the flume. As these dunes moved toward the upstream baffle plate, it appeared that the baffle would be covered. However, when each dune reached a point within $1 \mathrm{ft}$ of the baffle plate, the downstream side of the dune would begin to be carried into suspension; in this manner, most of the dunes were prevented from covering the baffles. Occasionally, however, the dunes were sufficiently large to cover the upstream baffle and move on to the second baffle. In moving from the upstream baffle to the second baffle, a higher percentage of such a dune was carried into suspension so that the dune was never able to cover completely any of the baffles in the second row. As the dune moved downstream, the upstream baffle slowly emerged through the top of the dune. The dune was rapidly forced into suspension by the increased turbulence and was carried downstream.

The vertical distribution of velocity and sediment as defined by point-integrated sediment samples at section $D$ indicates, to some extent, the capability of the turbulence flume to suspend the total sediment load. The sediment concentration and the distribution of coarse sediment particles are relatively uniform throughout the depth most of the time; therefore, the flow can be considered sufficiently turbulent to maintain the total sediment load in suspension. Figures 11,12 , and 13 show some of the information from point samples collected at the flume on 3 different days. In these figures, the percentages by weight of sediment coarser than 0.25 millimeter have been plotted against depth. The size division at 0.25 millimeter was selected because it represents a sufficiently coarse fraction of the sediment to reflect the capability of the flume to suspend the entire sediment load. The basic distributions illustrated in these figures persist at all times exeept when flow through the flume is affected by debris or ice.

Onty one sample has been collected from bed material that has been deposited on the sill. (See table 4, sec. D.) The sample is much caarser than bed-material samples at the selected river sections.

\section{SELECTED RIVER SECTIONS}

\section{SECTMON A}

Section $A$, the farthest upstream section in the reach, is about 7,200 feet upstream from the turbulence flume and about 6,000 feet upstream from the gaging station. (See fig. 2.) This section is the widest selected river section in the reach (pl. $4 A$ ) and is typical of other wide sections of the stream. Bank-to-bank width is about 340 feet; however, flow usually is not distributed over the entire width but 

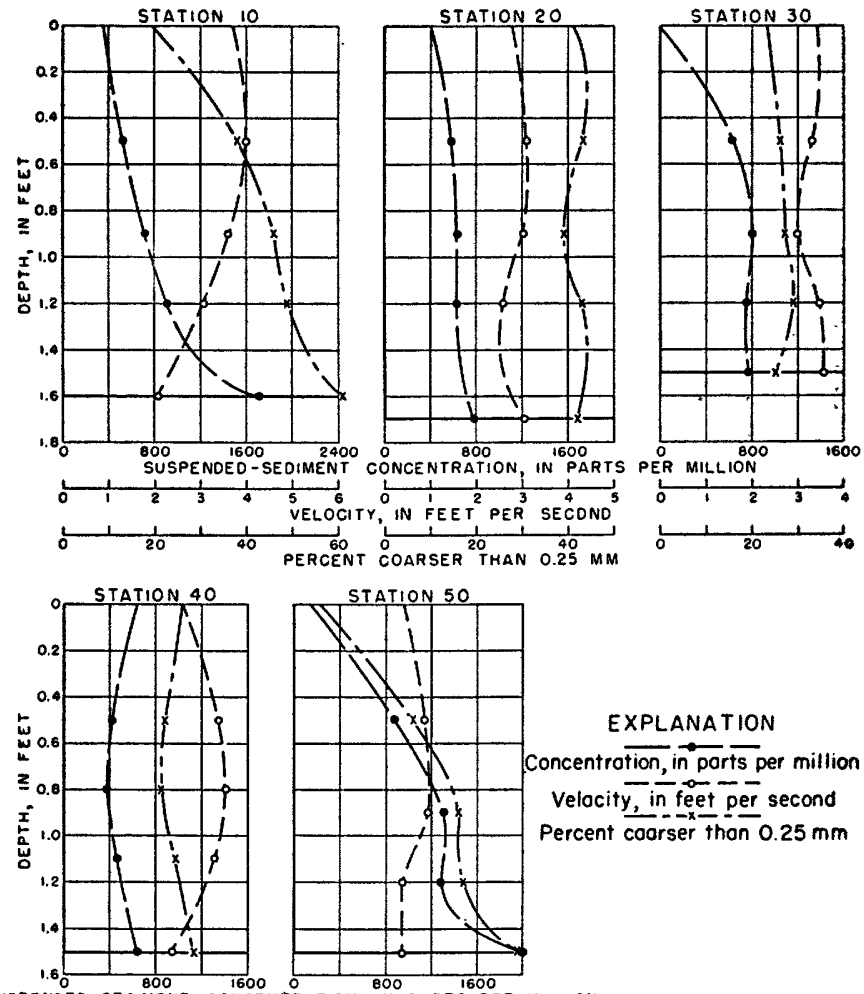

EXPLANATION

Concentration, in ports per million Velocity, in feet per second Percent coorser thon $0.25 \mathrm{~mm}$

SUSPENDED-SEOIMENT CONCEINTRATION, IN PARTS PER MILLION

$$
\text { PERCENT GOARSER THAN }{ }^{20} \text { O.25 MM }
$$
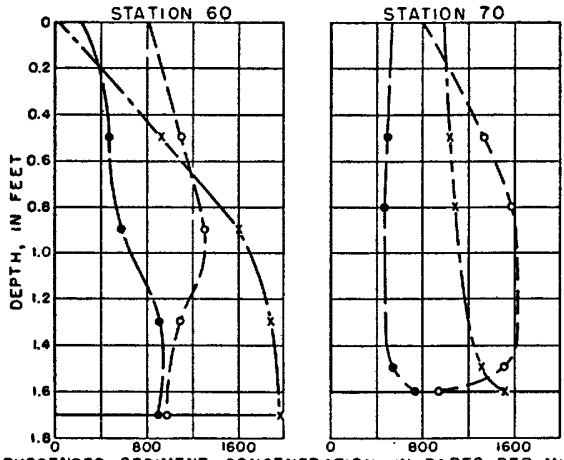

SUSPENDEO-SEDIMENT CONCENTRATION, IN PARTS PER MILLION

$$
\begin{gathered}
\text { 20 I INENT COARSER THAN D.25 MM } \\
\text { PERCENT }
\end{gathered}
$$

Figure 11.-Vertical distributions of suspended-sediment concentration, velocity , and percent coarser than $0.25 \mathrm{~mm}$, section $\mathrm{D}$, August 30, 1950 . 

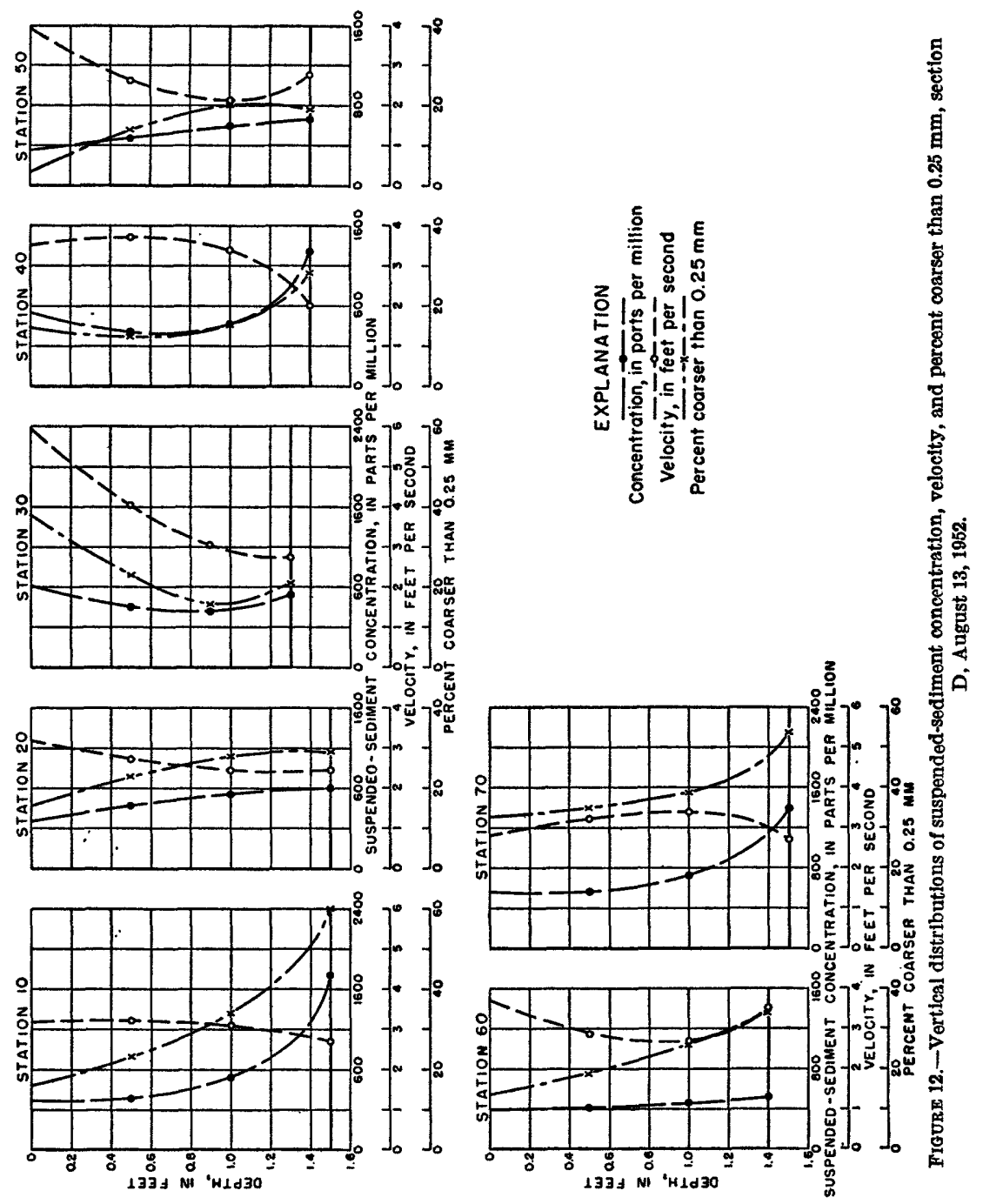

통

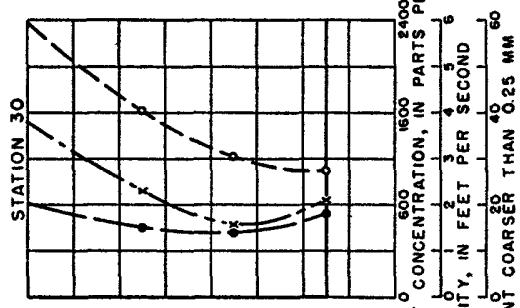



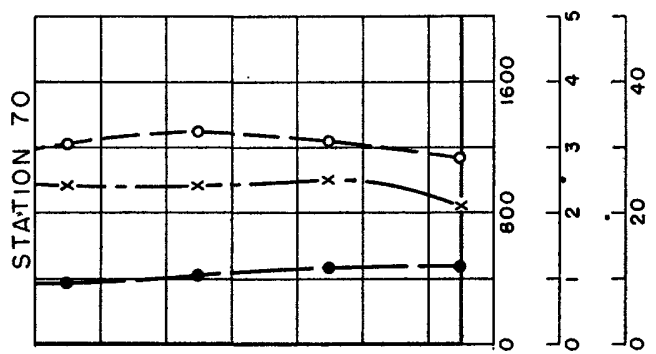

今̊

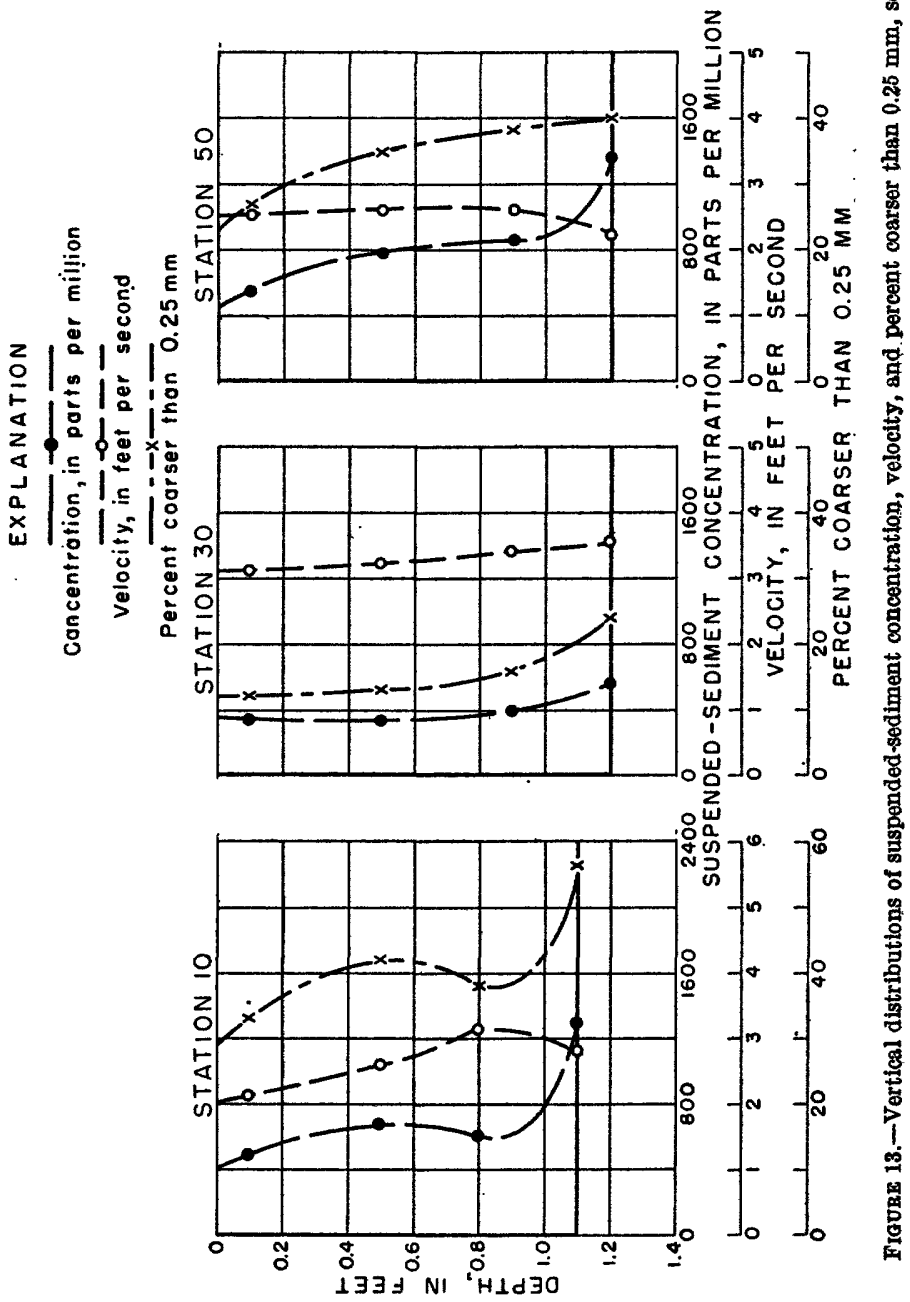


is interspaced with either sandbars or pools of still water. Generally, up to one-third of the width of flow is less than 0.5 foot deep. The sand-bed configuration is continually changing, rapidly at times, as dunes migrate into and through the section. Dune heights and widths vary across the section. Low ( 0.2 foot), wide dunes are generally in the shallower parts of the section. However, flows at shallow depths do not always cause low, wide dunes; sometimes they form a flat plateaulike bed whose downstream edge is actually a long dune crest. When flow is swift over these flat beds, bed load is transported to and deposited at these downstream edges. In deeper flows, dune heights range from only a few tenths to nearly a foot. Generally, the higher dunes are relatively narrow. The upstream and downstream faces of these dunes have relatively steep slopes, and the depressions or troughs between successive dunes give an impression of holes in the stream bed.

Because of the irregularities across the section in both the streambed configuration and the water discharge, section $\mathrm{A}$ is unfavorable for either measuring water discharge or sampling suspended sediment; it is particularly unfavorable unless a relatively large number of verticals are measured or sampled. However, water- and sedimentdischarge measurements are made at this section because it typifies other wide sections of the stream.

At section A the cross-sectional area of flow in the shallow parts of the stream represents usually a substantially larger percentage of the total area than the discharge in the shallow parts does of the total discharge. As a result, mean section velocities computed by dividing the total measured discharge by the total measured area are often low with respect to the velocities associated with the areas of major sediment discharge. Therefore, these mean section velocities are unsuitable in computations of sediment discharge with methods in which the mean velocity is an important parameter.

Particle-size analyses of the measured suspended sediment show that about 40 percent is in the 0.125 - to 0.25 -millimeter size range and about 75 percent is coarser than 0.062 millimeter, whereas particlesize analyses of the bed material show that about 45 percent is in the 0.25 - to 0.50 -millimeter size range and about 70 percent is coarser than 0.25 millimeter. The measured suspended-sediment size distribution and the bed-material size distribution for two medium flows are shown in figure 14.

Lateral distributions of stream velocity, depth, and measured suspended-sediment concentration on 3 days are given in figure 15. Parts of the measured suspended-sediment concentration curves are undefined because no samples were collected in the separate channels or because the velocity of flow reached zero and no samples were collected 

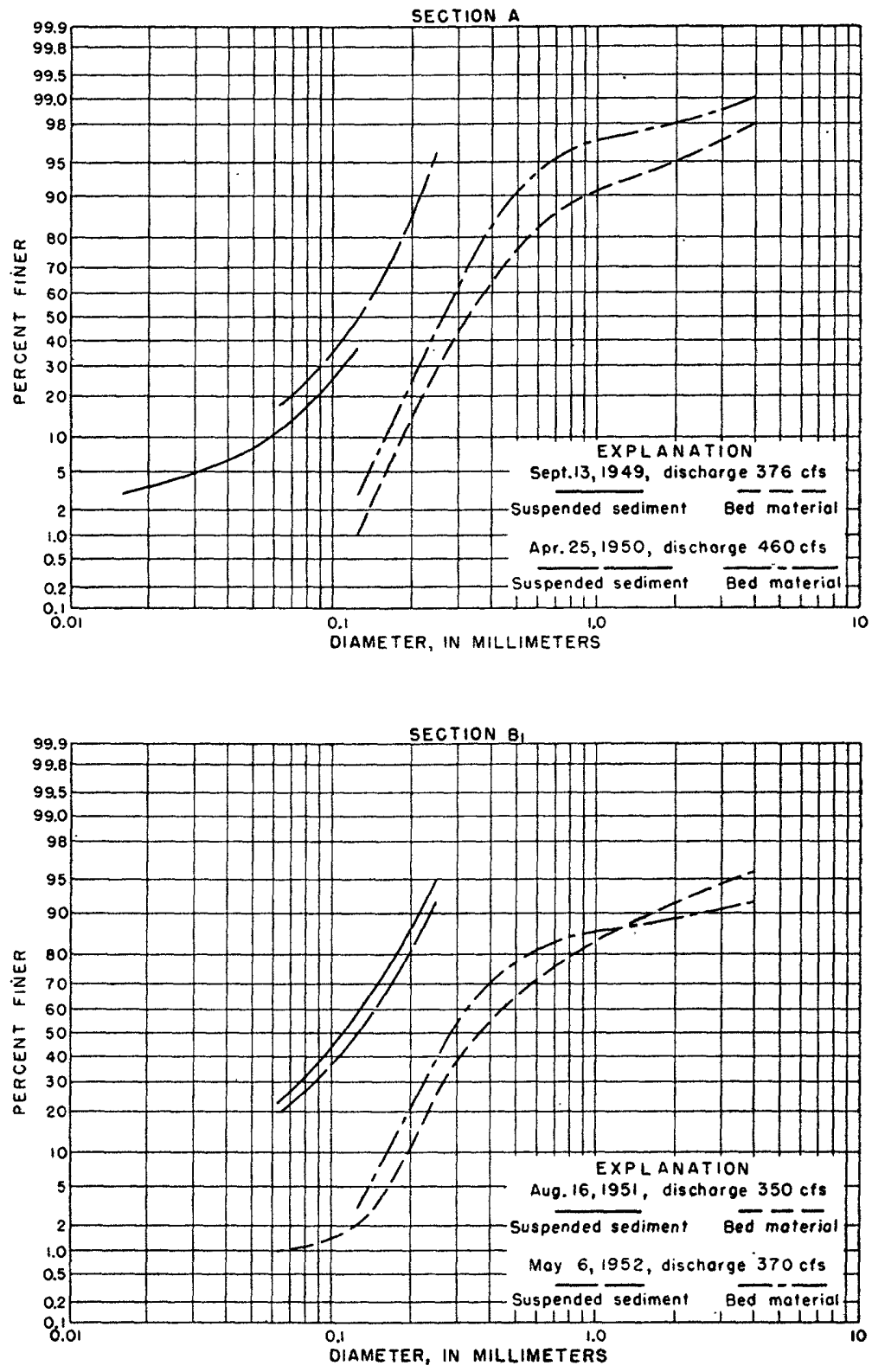

FiguRE 14.-Particle-size distributions of measured suspended sediment and bed material, sections $A$ and $B_{3}$. 

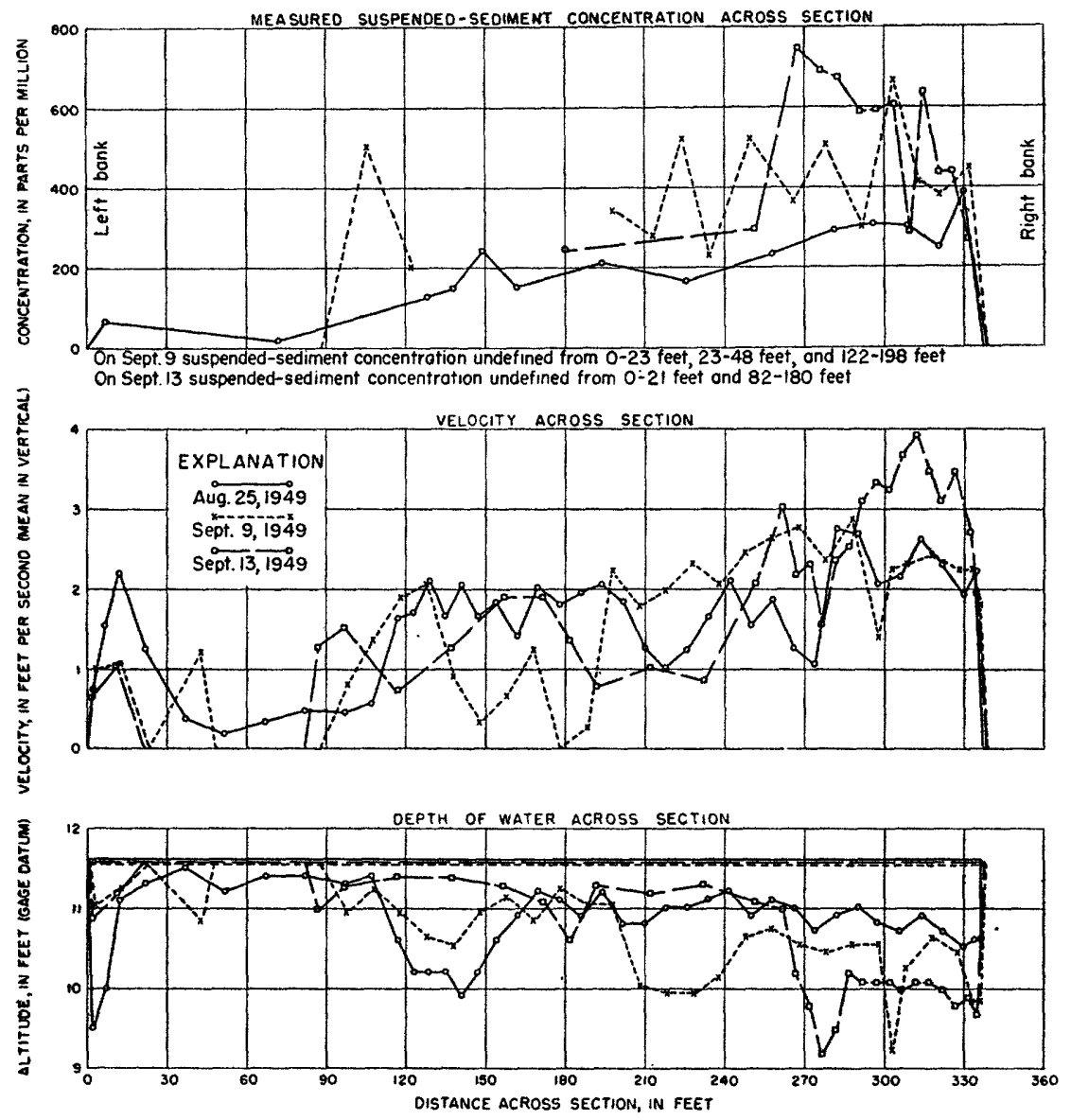

Fioure 15.-Lateral distributions of depth, stream veloeity, and measured suspended-sediment concentration, section A.

at near the point of zero velocity. No point-integrated samples were collected; so the vertical distributions remain undefined.

Staff gages were placed on both banks at section $A$ and on both banks 300 feet upstream and downstream from section $A$; however, the local water-surface slope determined from the readings of these gages usually is questionable. The slope varies across the section from one individual channel to another. Also, transverse flow at the section causes differences in the slope along each bank. Despite these difficulties, local slopes were determined as well as possible. In addition, overall slopes from section $\mathrm{A}$ to section $\mathrm{E}$ (fig. 2) are defined by the gage-height traces from temporary water-stage recorders at both sections. 
SECTION $\mathbf{B}_{1}$

Section $B_{1}$ is about 1,400 feet upstream from the turbulence flume and about 200 feet upstream from the gaging station. (See fig. 2.) It is at the upstream end of the straight approach to the flume and is narrower than most sections of the stream-usually about 95 feet wide. The hydraulic characteristics of the section are not affected by backwater except occasionally when ice lodges at the county bridge, 150 feet downstream, or at the flume. The sand-bed configuration changes rather slowly, and the bed is scoured at times along the left bank to a deposit of peat. Ordinarily, the bed shape remains fairly constant. As a result of these factors, section $B_{1}$ is one of the better sites for stream gaging.

At this section, about 80 percent of the measured suspended sediment is coarser than 0.062 millimeter. Particles larger than 0.50 millimeter are rare, and the largest percentage in any size range is about 40 percent in the 0.125 - to 0.25 -millimeter range. The median diameter of bed material, as that at the other selected sections, falls in the $0.25-$ to 0.50 -millimeter size range. The measured suspendedsediment size distribution and the bed-material size distribution are shown in figure 14.

Stream depth and velocity are usually fairly uniform across the section. Lateral distributions of these quantities and of measured suspended-sediment concentration on 3 different days are shown in figure 16.

At this section, local water-surface slopes were not determined and point-integrated sediment samples were not collected.

\section{SECTION B}

Section $B$ is at the county bridge about 150 feet downstream from section $B_{1}$ and about 50 feet upstream from the gaging station. (See fig. 2 and pl. 4B.) Both the upstream and the downstream sides of the bridge have been designated as section $\mathrm{B}$. The daily sampling station, Middle Loup River at Dunning, was maintained at this section from April 11, 1946, to March 21, 1950, and measured suspended-sediment loads during that period are published in watersupply papers (U. S. Geological Survey, 1953, 1954, 1955).

Because the section is more constricted than the others, the measured suspended-sediment discharges are higher than those at the other selected river sections and the measured suspended sediment is slightly coarser, although the bed material has about the same size distribution.

The flow at this section is confined by the bridge abutments to a width of about 65 feet. Although the bed configuration changes radically from time to time, the stream velocity across the section is fairly uniform, and the section is usually satisfactory for stream 


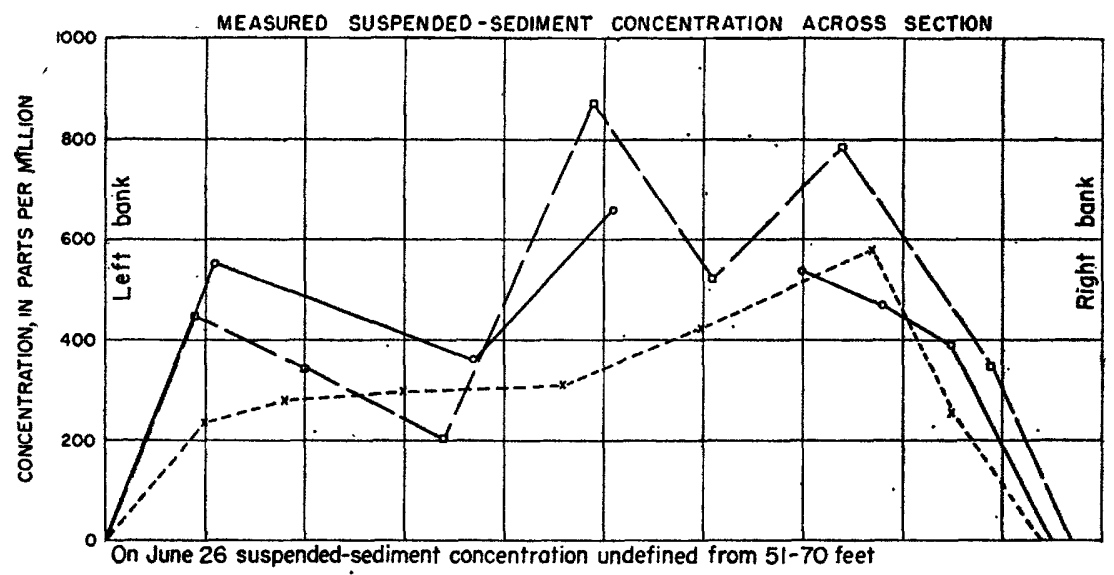

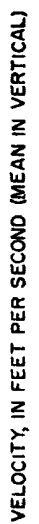
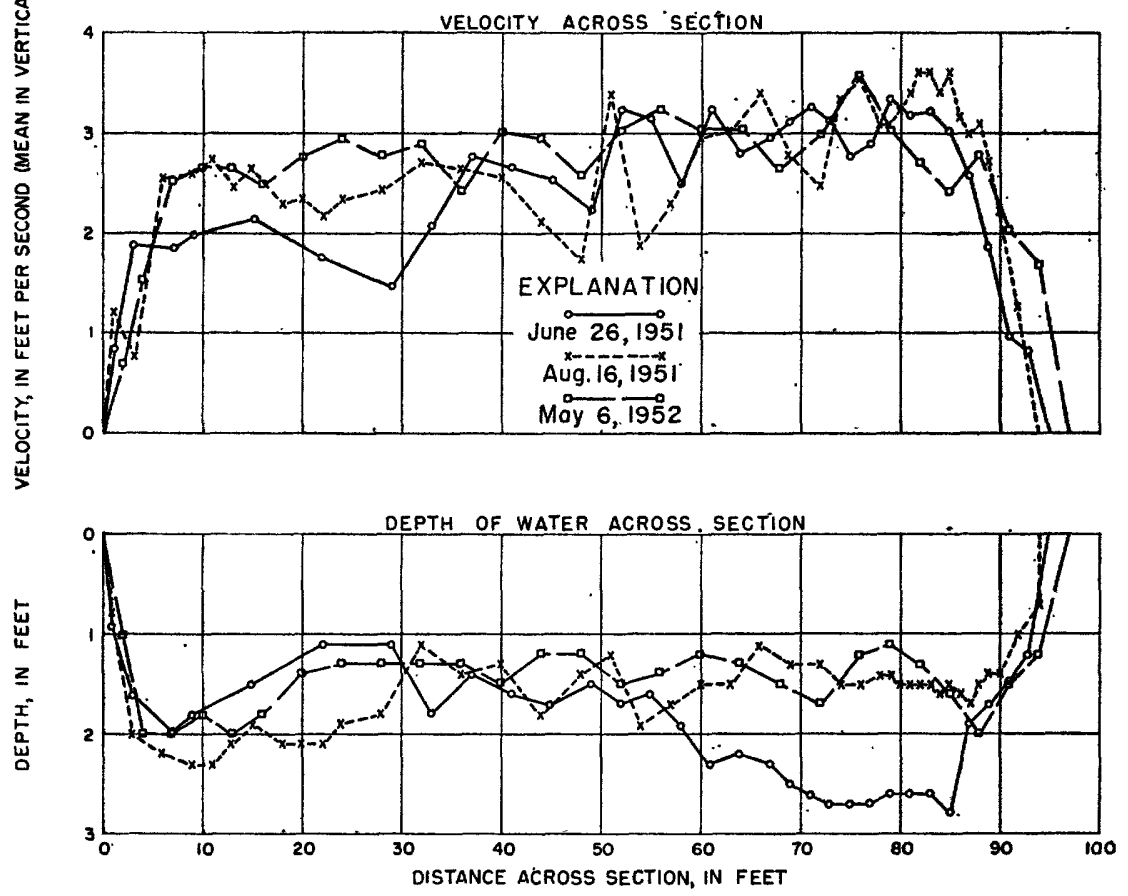

Frauke 16.-Lateral distributions of depth, stream velocity, and measured suspended-sediment concentration, section $B_{1}$.

gaging. The measured suspended-sediment concentration is also fairly uniform across the section. Lateral distributions of measured suspended-sediment concentration, stream velocity, and depth are shown in figure 17.

Some point-integrated samples have been collected at section $B$. Vertical distributions of velocity, suspended-sediment concentration, 

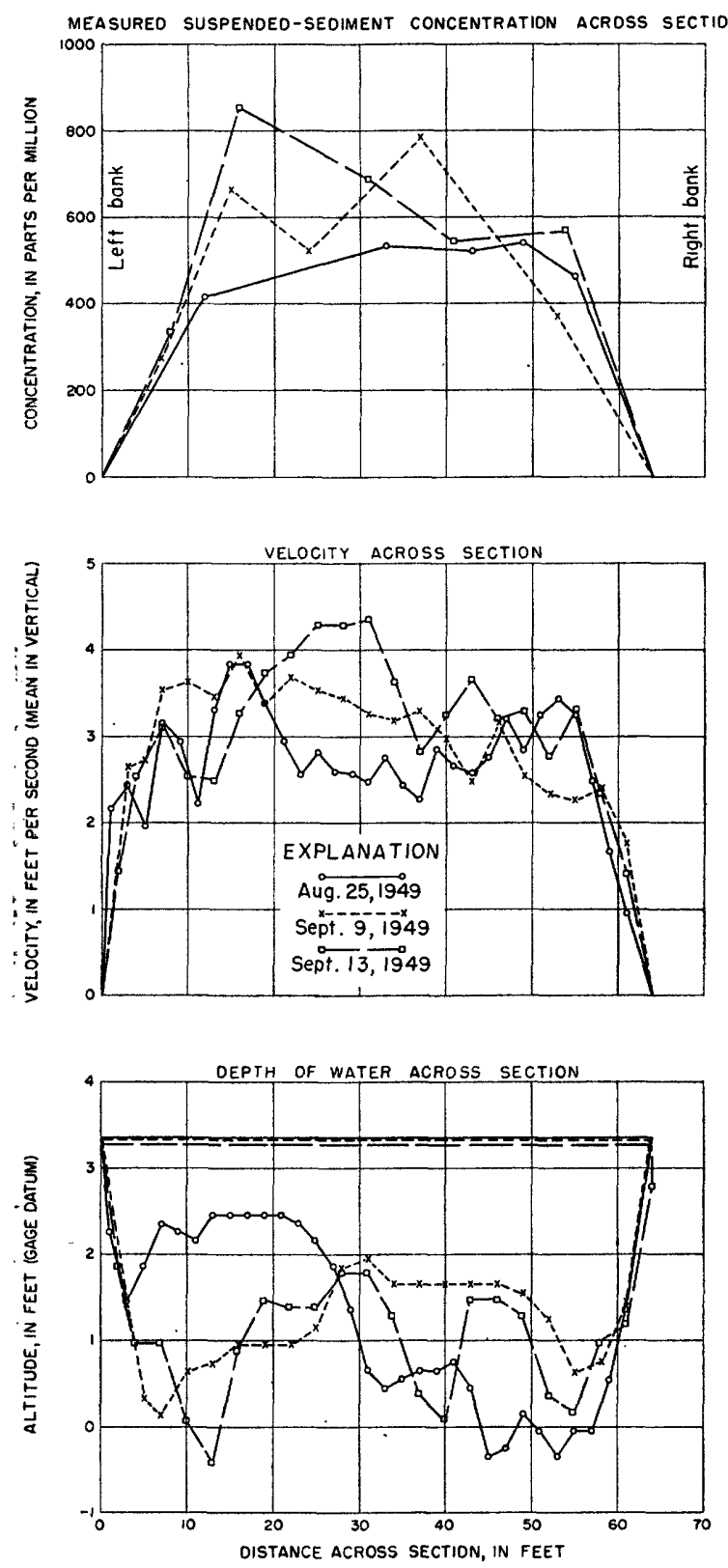

FIGURE 17.-Lateral distributions of depth, stream velocity, and measured suspended-sediment concentration, section $\mathbf{B}$. 
and percentage coarser than 0.25 millimeter from these samples are shown in figure 18. These vertical distributions indicate that the flow at section $B$ is somewhat more turbulent than would be expected at an unconfined alluvial section.

Water-surface slopes were not determined at section B.

Measurements of water and suspended-sediment discharges were made at a section 25 feet upstream from the upstream side of the county bridge. This section has not been listed separately because only three measurements were made there; however, these measurements are used in subsequent computations. Information from these measurements as well as particle-size analyses of both measured suspended sediment and bed material is given with similar data for section $B$.

Two of the water-discharge measurements show that the section 25 feet upstream from section $B$ is about 71 feet wide. The third measurement was evidently not made at exactly the same section as the other two because the width is given as 77 feet. Lateral distributions of depth and stream velocity for the two similar measurements are shown in figure 19. The lateral distribution of measured suspended-sediment concentration is not defined because suspendedsediment samples were not analyzed by individual verticals.

Neither local-slope data nor point-integrated samples were collected at the section 25 feet upstream from section $B$.

\section{SECTrON $\mathbf{C}_{2}$}

Section $\mathrm{C}_{2}$ (pl. $5 A$ ) is about 600 feet upstream from the entrance of the turbulence flume and about 540 feet downstream from the gaging station. (See fig. 2.) Usually, it is a reasonably good gaging section and the sand bed is no more changeable than that at any of the other sections in the reach. However, at times the top part of the bed approaches an almost fluid state, and then the accuracy of the streamflow measurement is somewhat questionable.

The particle-size distributions of both the measured suspended sediment and the bed material at section $\mathrm{C}_{2}$ are about the same as those at the other normal sections. Several distributions for section $\mathrm{C}_{2}$ are shown in figure 20.

Section $\mathrm{C}_{2}$ is about 83 feet wide. The greatest depths and the largest measured suspended-sediment concentrations are ordinarily in the left half of the channel, although the stream velocity is usually fairly uniform across the section. Lateral distributions of stream depth, velocity, and measured suspended-sediment concentration are shown in figure 21 on 3 different days.

Since the spring of 1952 , both banks at and near section $\mathrm{C}_{2}$ have been stabilized with brush riprap. The addition of the riprap affected 


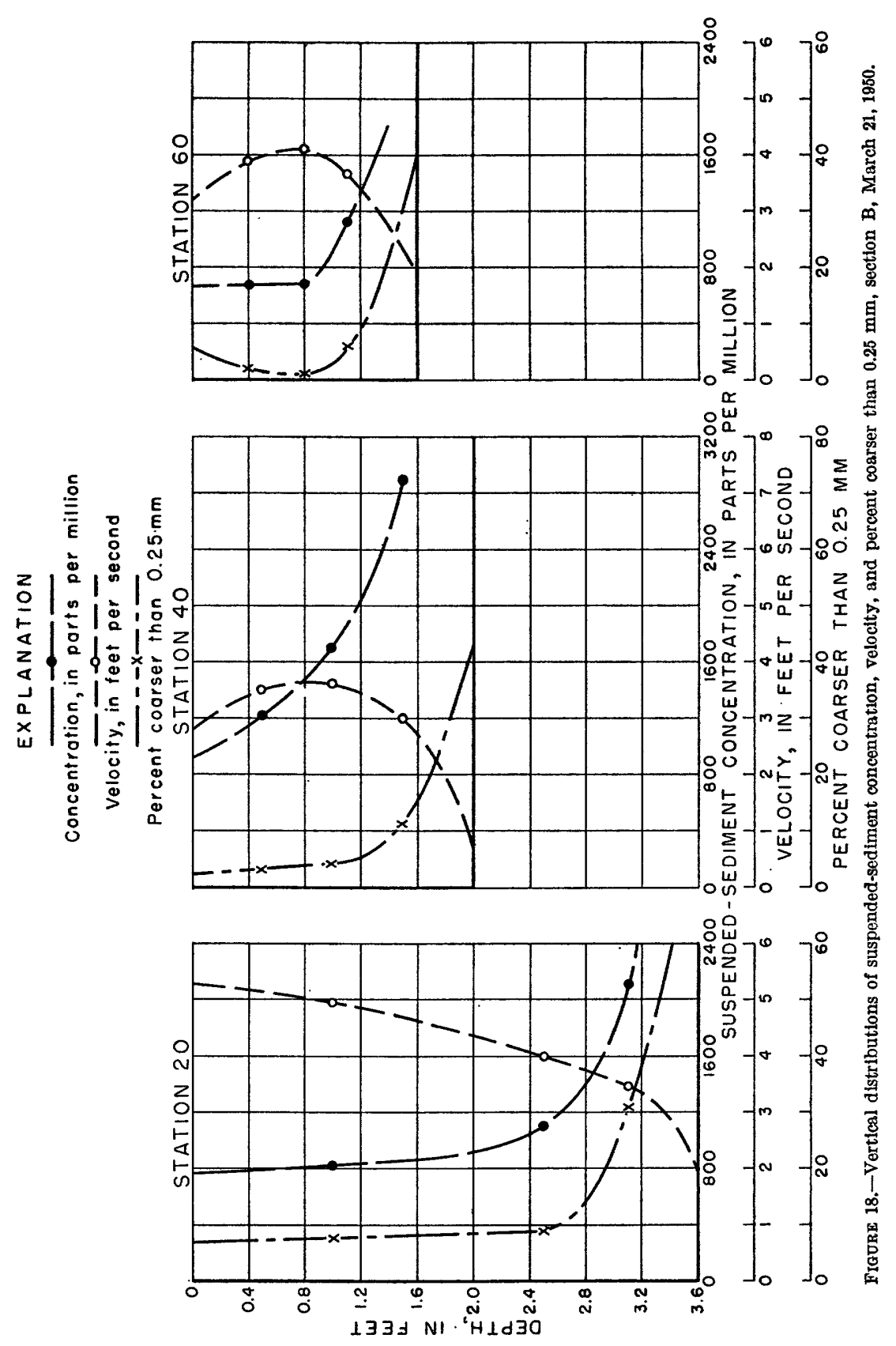



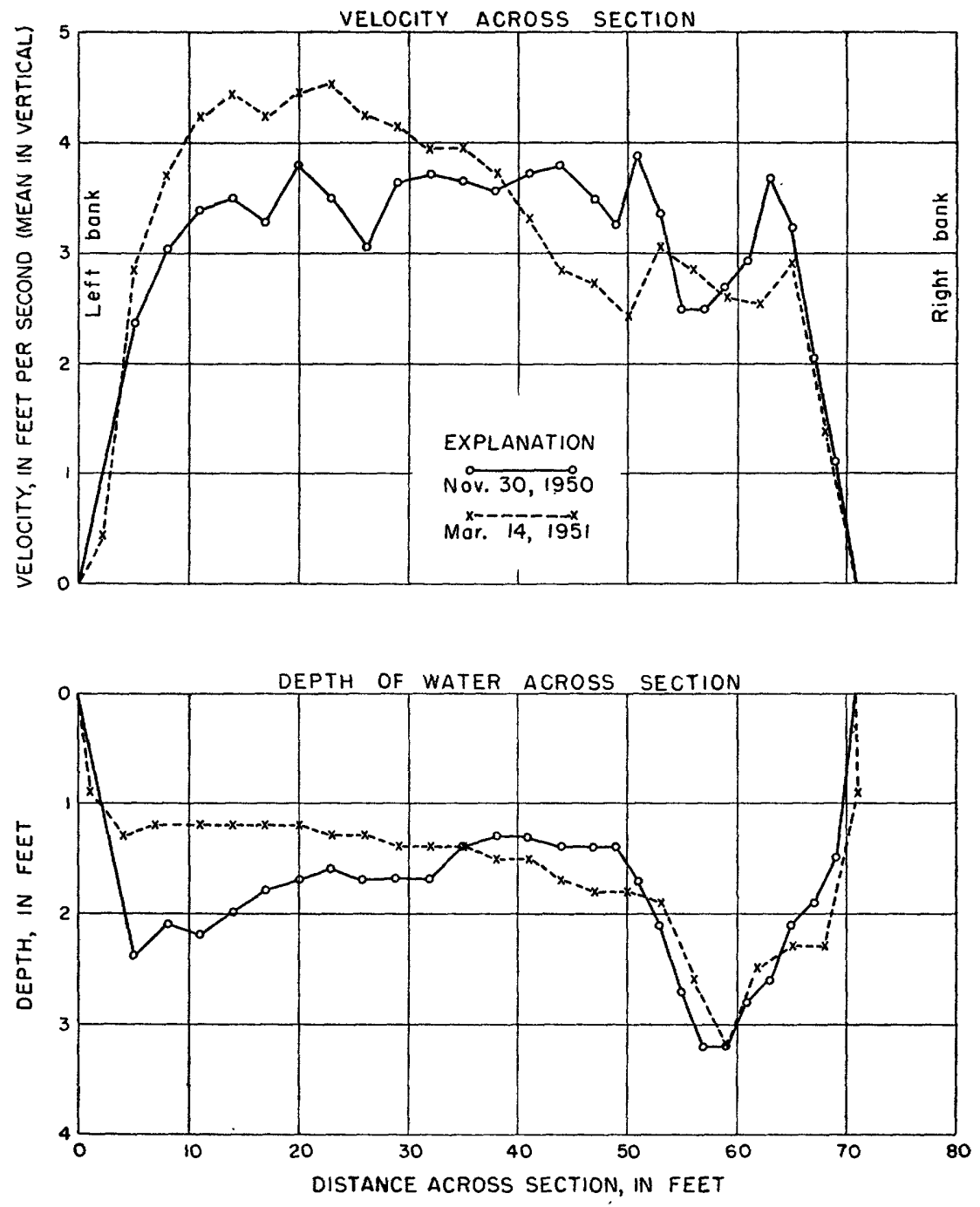

Frouke 19.-Lateral distributions of depth and stream velocity, 25 foet upstream from section B.

the section only on the left bank for a distance of about 8 or 9 feet into the channel. This effect is best seen in figure 21 by comparing curves for May 6, 1952, with curves for the other 2 days.

Staff gages are on both banks at the section and 300 feet upstream and downstream from the section. Local slopes have been determined from the readings of these gages except at times when backwater from lodged ice at the flume affected the section. 

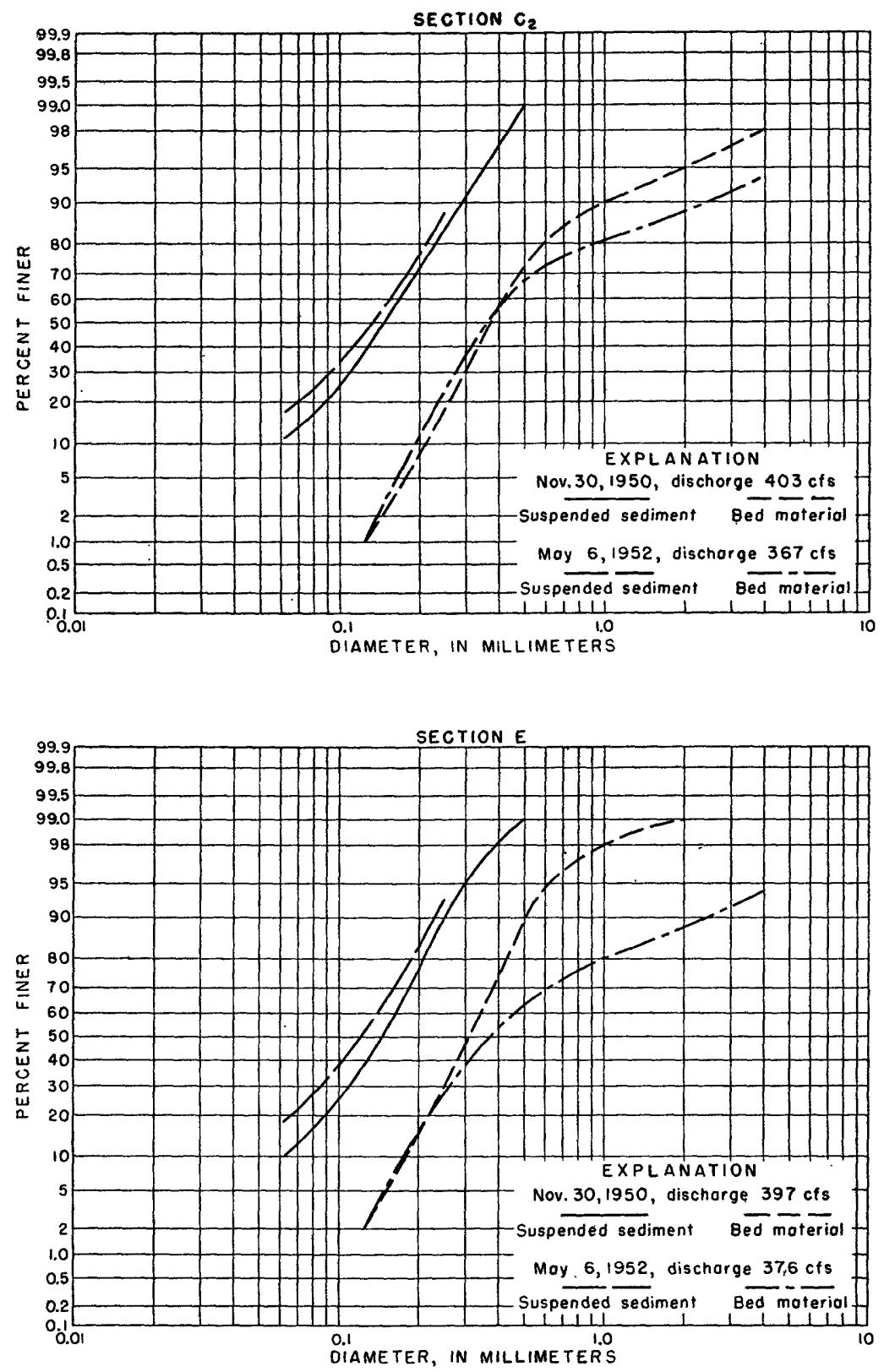

Figure 20.-Particle-size distributions of measured suspended sediment and bed material, sections $\mathrm{C}_{2}$ and $\mathrm{E}$. 


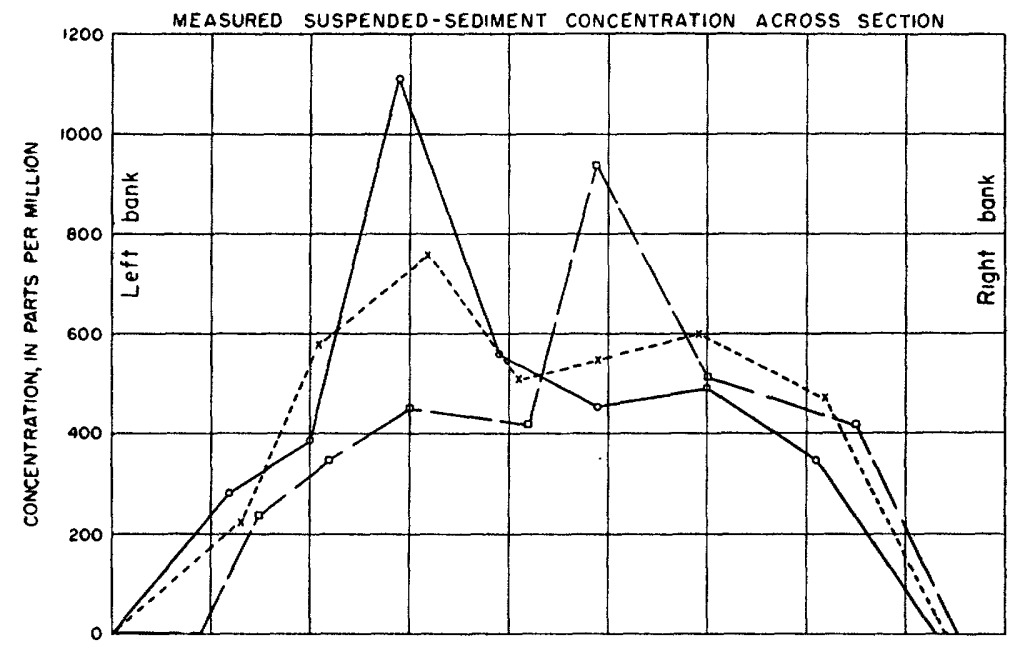

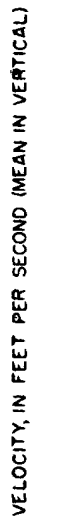
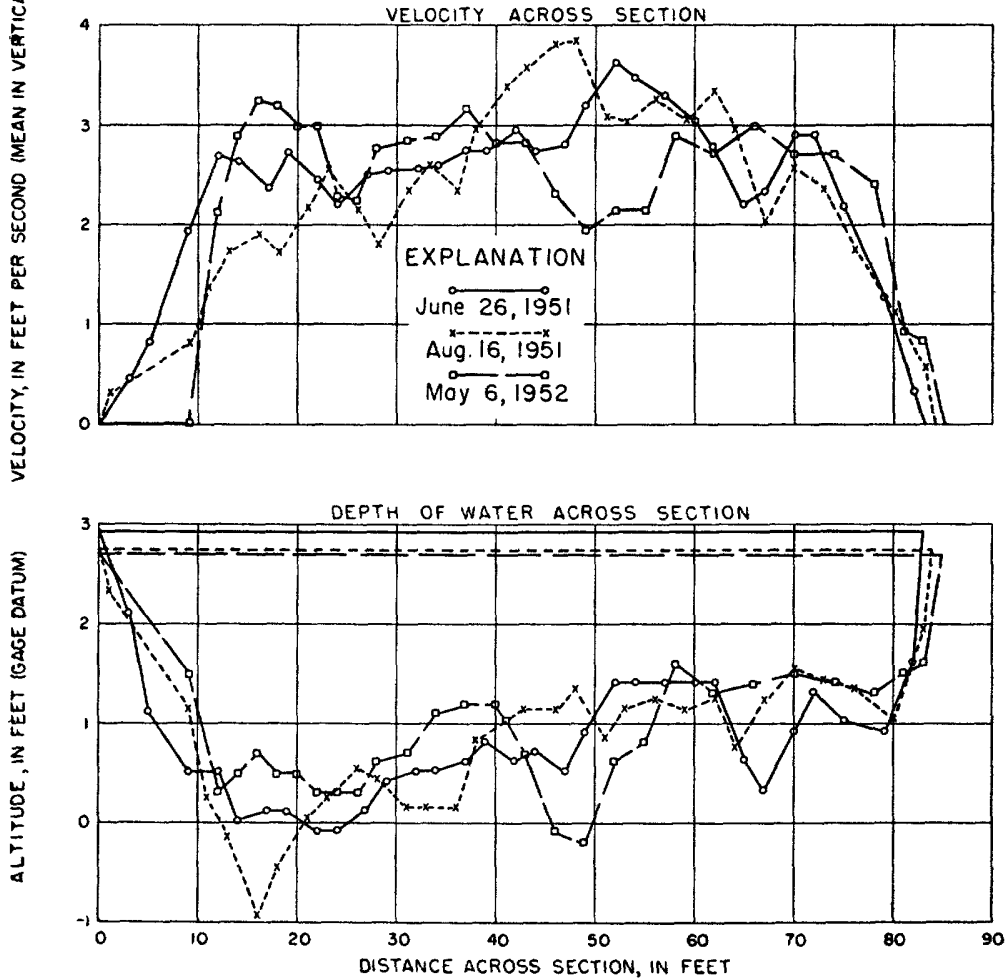

Figure 21.-Lateral distributions of depth, stream velocity, and measured suspendedsediment concentration, section $\mathbf{C}_{2}$. 


\section{SECTION $C_{1}$}

Section $\mathrm{C}_{1}$ is about 195 feet upstream from section C. (See fig. 2, and pl. $5 A$.) Only 2 water-discharge measurements and 4 suspendedsediment discharge measurements were made at this section. Also, 1 measurement of streamflow and suspended-sediment discharge was made at a section 300 feet upstream from section $C$, and data from this measurement have been included with those from section $\mathrm{C}_{1}$.

Section $C_{1}$ is similar to section $C_{2}$ except that the depths and velocities across the section are more uniform. No information is available on the lateral distribution of measured suspended sediment; so figure 22 shows only the lateral distributions of depth and velocity defined by the two streamflow measurements at the section.

The slope of the water surface at section $C_{1}$ is affected by backwater from the turbulence flume. Water-surface profiles along both banks on July 8, 1952, (fig. 4) show that the slope is generally flatter in the approach to the flume than in other reaches near Dunning. Because
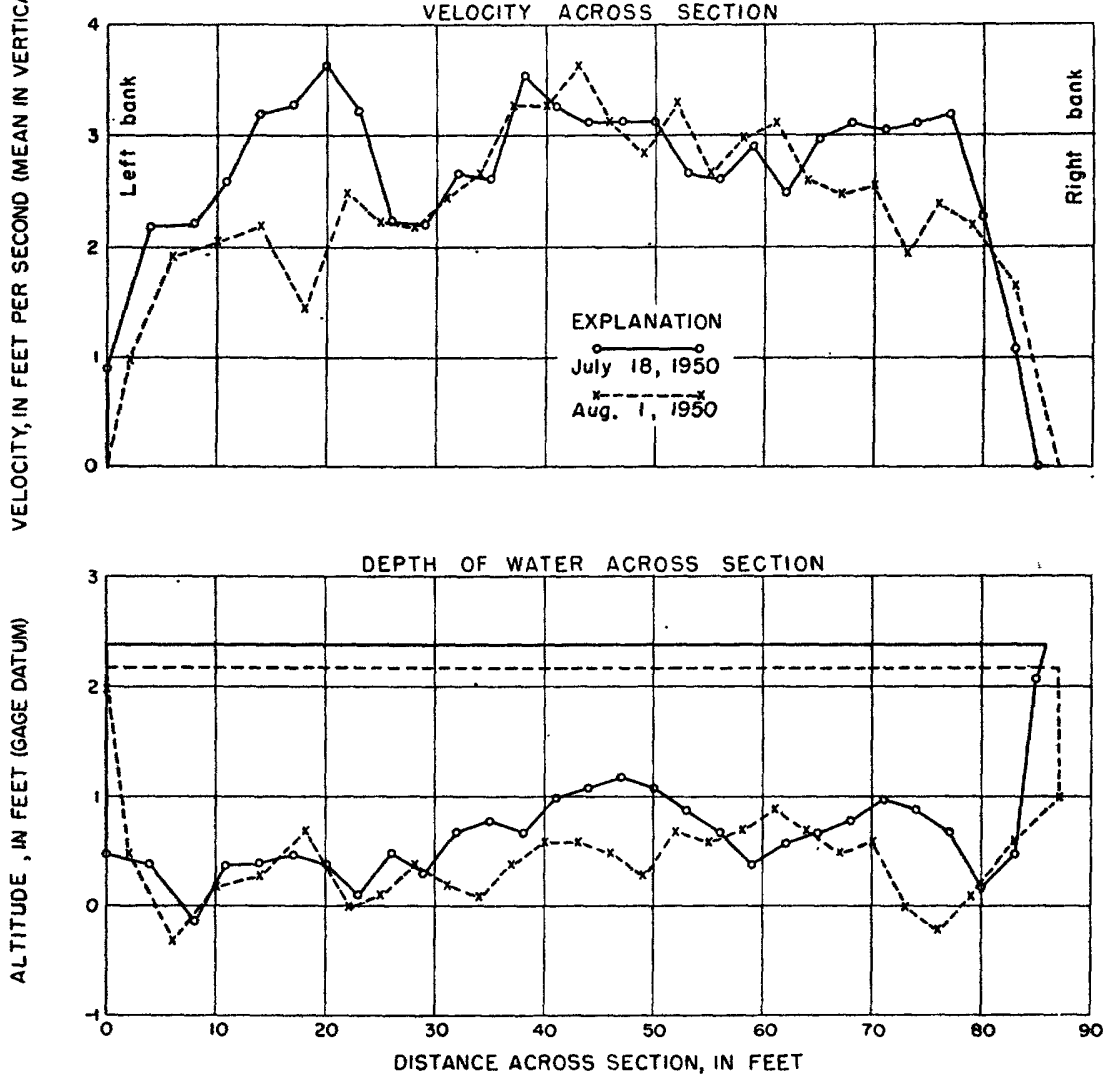

Figure 22.-Lateral distributions of depth and stream velocity, section $C_{t}$. 


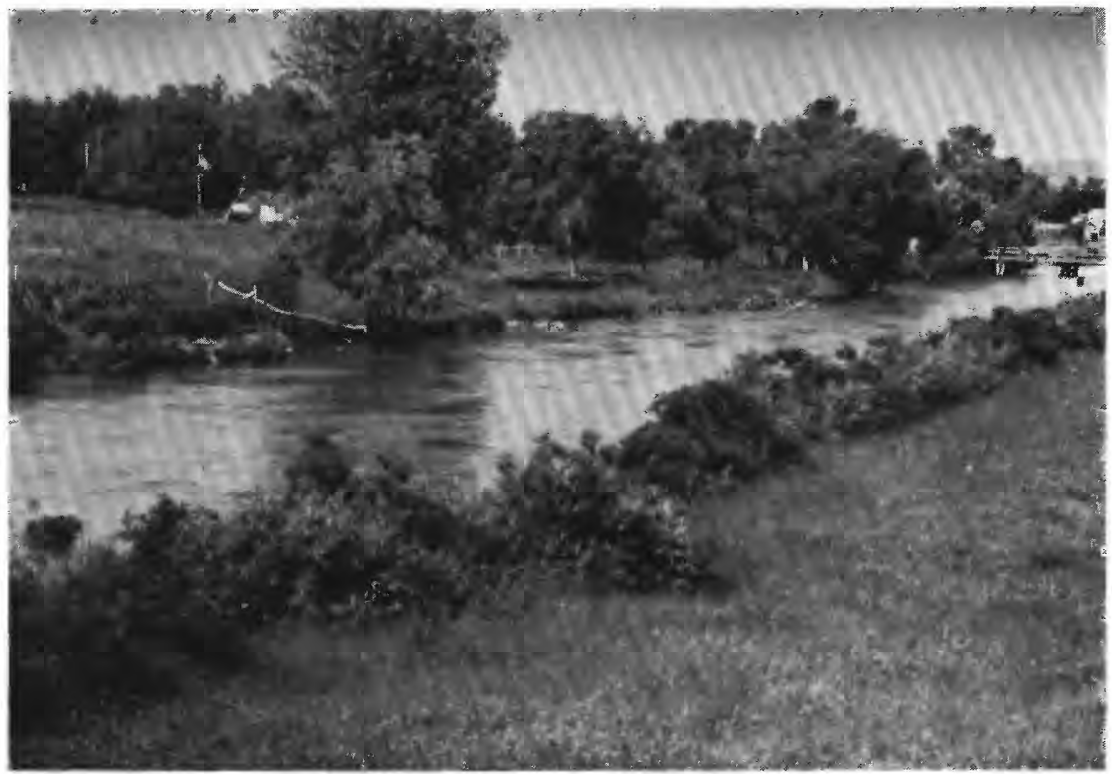

A. CHANNEL REACH FROM THE LEFT BANK

This reach is between the State highway and county-road bridges. Section $\mathrm{C}_{1}$ is at the left. July 14, 1953, water discharge about $350 \mathrm{cfs}$.

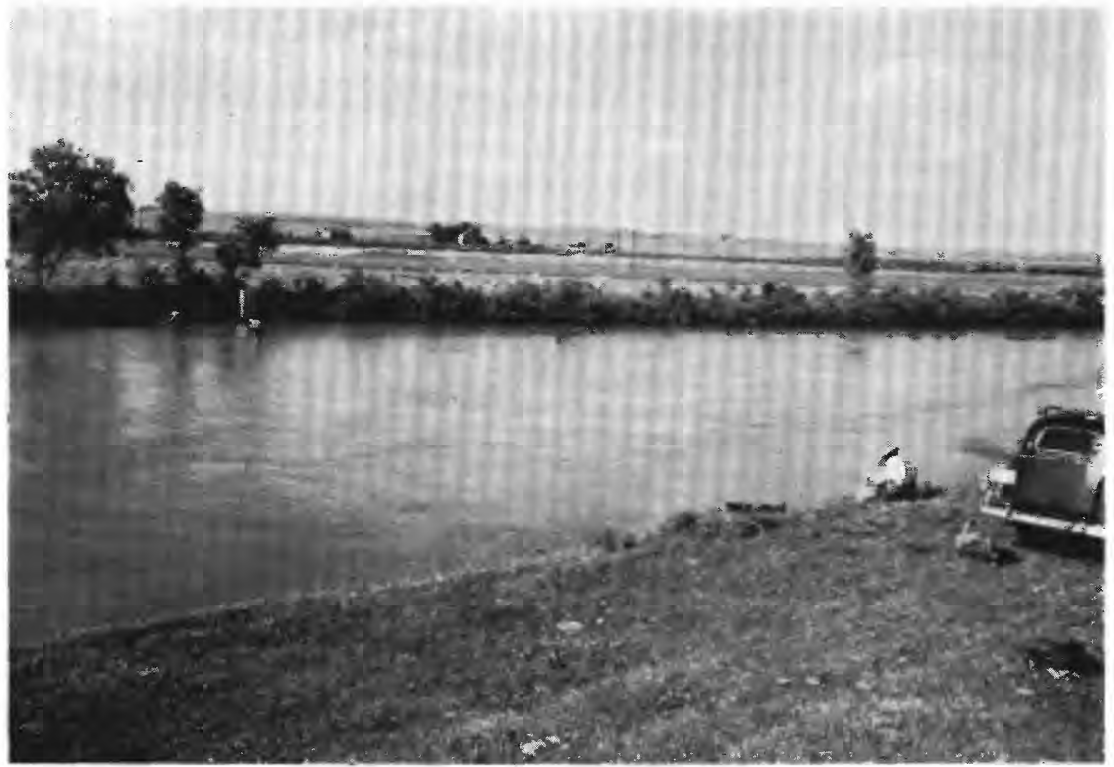

B. SECTION E FROM THE RIGHT BANK

The men in the stream mark the section. The temporary water-stage recorder at the left bank is about 15 feet downstream. July 14, 1953, water discharge about $350 \mathrm{cfs}$. 

section $\mathbf{C}_{1}$ is in the area of changing slope, measurements were discontinued there; subsequent measurements were made at section $\mathrm{C}_{2}$.

\section{SECTION E}

Section $\mathrm{E}$ (pl. $5 B$ ) is more typical of the channel in the reach near Dunning than any of the other selected sections. It is about 700 feet downstream from the turbulence flume and about 1,900 feet downstream from the gaging station. (See fig. 2.) The width of the section is about 150 feet, and the highest water discharge per foot of width is generally near the right bank. Sandbars form in the center of the channel during periods of low flow and cause some transverse flow. Changes in the sand-bed configuration are less rapid at section $E$ than at any of the other selected sections with the exception of section $B_{1}$, even though the type of dune movement and the configuration of dunes are similar to those at section A. As a result of these channel characteristics, section $\mathrm{E}$ is a good gaging section.

The size distribution of the measured suspended sediment at section $\mathrm{E}$ is about the same as that at the other selected river sections. About 80 percent of the measured suspended sediment is coarser than 0.062 millimeter, and about 40 percent is in the 0.125 - to 0.25 millimeter size fraction. Many bed-material samples were collected at section $\mathrm{E}$. Included with the ordinary samples are special samples collected to determine the extent of the lateral variation of bedmaterial size distribution. In addition, other special samples were collected to determine the variation of bed-material size distribution with depth into the bed. The measured suspended-sediment size distribution and the bed-material size distribution for two medium water discharges are shown in figure 20.

Generally at section $E$, the greatest depths are along both banks, although the stream velocity is fairly constant across the section except when sandbars are present. However, the measured suspendedsediment concentration follows no consistent lateral pattern. Lateral distributions of stream depth, velocity, and measured suspendedsediment concentration on 3 days are shown in figure 23 .

The turbulence flume upstream seems to have little effect, if any, on the hydraulic or sediment characteristics of section $\mathrm{E}$. The profiles in figure 4 and the readings from staff gages on both banks at section $E$ and 300 feet upstream and downstream from section $E$ show that the local water-surface slope is about the same as that at the other sections not influenced by the flume.

\section{GAGING SECTIONS}

The gaging sections normally used for water-discharge measurements for the gaging station are included in the reach between sections 


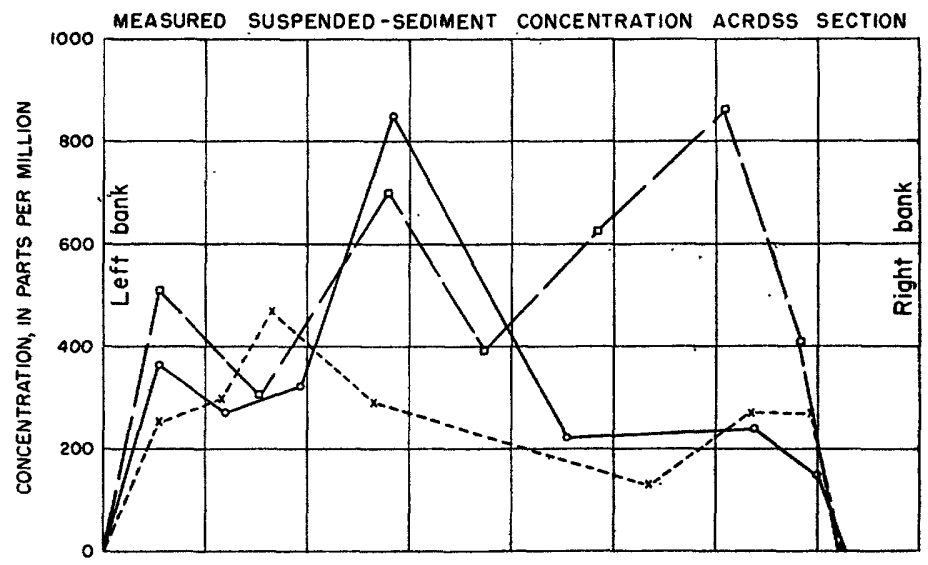

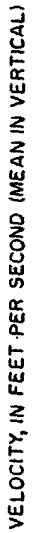
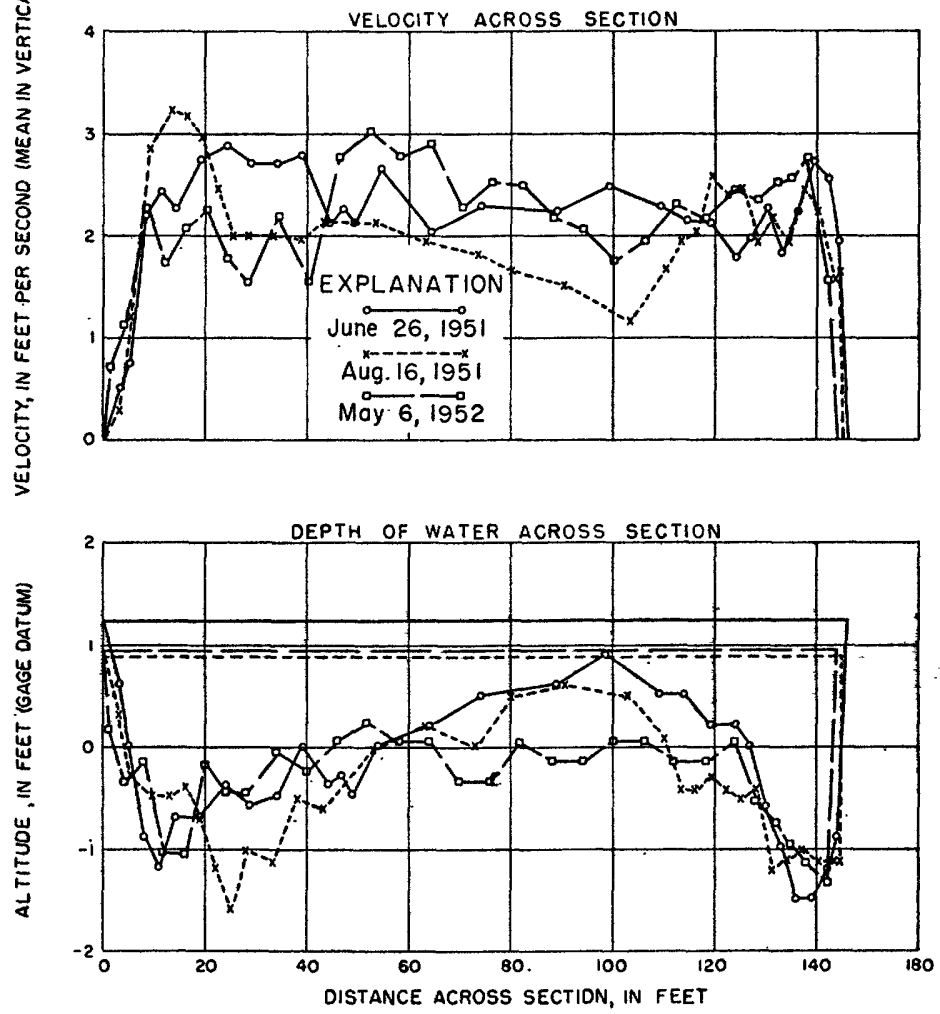

Figure 23.-Lateral distributions of depth, stream velocity, and measured suspendedsediment concentration, section $\mathbf{E}$. 
$B_{1}$ and $C_{2}$ (fig. 2). Throughout this reach, the channel is straight, and the shape and stability of the bed at any gaging section are fairly similar to those at the nearest selected section.

In this report, the term "gaging section" refers to a section which is not one of the selected river sections and at which only streamflow measurements were made. Whenever streamflow and sediment data were concurrently collected at any section other than a selected section, these data are included with the data for the nearest selected section and are differentiated from the selected section by an appropriate footnote. Such data should be treated as though they were collected at the selected section.

\section{SEDIMENT DISCHARGES BY FORMULAS}

One of the purposes of the turbulence flume is to provide information that can be used for evaluating the accuracy of formulas and methods for computing the sediment discharge of streams having sediment and hydraulic characteristics similar to those of the Middle Loup River. The accuracy of methods that give the total sediment discharge or the bed-material discharge can be evaluated by directly comparing computed discharges with measured total sediment discharges or measured bed-material discharges. However, the accuracy of methods that give the bed-load discharge or the discharge of sediment on and near the bed can only be estimated. Unmeasured sediment discharge, which can be determined from the measured total sediment discharge, can be used in estimating the accuracy. Ratios of the mean concentration in the unsampled zone to that in the sampled zone can also be used. The development of the final form of the equation for determining these ratios is as follows (a list of definitions of all symbols is given on p. 79): By definition (see p. 10)-

in which-

$$
Q_{u M}=Q_{t s}-Q_{s M}
$$

$Q_{u M}$ is the unmeasured sediment discharge, in tons per day.

$Q_{t s}$ is the total sediment discharge in the cross section in tons per day.

$Q_{s M}$ is the measured suspended-sediment discharge in the cross section, in tons per day. (See p. 19.)

Also, by definition (see p. 10) -

in which-

$$
\begin{aligned}
Q_{u M} & =Q_{u s M}+G_{b} \\
& =K_{o} K_{o o} Q_{v o}\left(C_{o n c}-\text { Conc }\right)+G_{b}
\end{aligned}
$$

$Q_{u s M}$ is the unmeasured suspended-sediment discharge, in tons per day.

$G_{b}$ is the bed-load discharge, in tons per day. 
$K_{o}$ is a constant for converting the units to tons per day.

$K_{o o}$ is the fraction of flow in the unsampled zone. (See p. 54, step 9.)

$Q_{w}$ is the water discharge, in cubic feet per second.

Conc $_{u}$ is the mean concentration, in parts fer million, of the suspended-sediment discharge in the unsampled zone.

Conc is the measured suspended-sediment concentration in parts per million (mean concentration in the sampled zone). By expressing $C_{o n c}$ as a factor $R$ times Conc-

and-

$$
\begin{aligned}
Q_{u s M} & =K_{o} K_{o o} Q_{w}(R \text { Conc-Conc }) \\
& =K_{o} Q_{w} \text { Conc }(R-1) K_{o o} \\
& =Q_{s M} K_{o o}(R-1)
\end{aligned}
$$

$$
\begin{aligned}
R & =\left(Q_{u s M} / Q_{s M} K_{o o}\right)+1 \\
& =\left[\left(Q_{t s}-Q_{s M}-G_{b}\right) / Q_{s M} K_{o o}\right]+1
\end{aligned}
$$

The factor $R$ is the number of times the mean concentration in the unsampled zone is greater than that in the sampled zone; or, in other words, it is the ratio of the mean concentration in the unsampled zone to that in the sampled zone. Of course, the ratio varies with the sediment and flow characteristics, the fraction of the depth sampled, and particularly the amount of wash load. High concentrations of wash load can mask out relatively large errors in bed-load discharge; however, the concentrations of wash load in the Middle Loup River are very low. If the ratios and any measurable parameters could be correlated, the total load could be estimated from the measured suspended-sediment load, the computed bed-load discharge, and a ratio.

Six different methods for computing sediment discharge are described and evaluated in this section of the report. These methods include the Einstein method, which computes the bed-nuaterial discharge; the modified Einstein procedure, which computes the total sediment discharge; and the Straub, Kalinske, Schoklitsch, and Meyer-Peter and Müller methods, which compute either the bedload discharge or the discharge of sediment on and near the bed. These methods were evaluated on the basis of computations, in many of which the same basic data were used. For each method, except for the Einstein procedure, enough computations were made to be sure that the computations were representative of the different conditions of the river and that reasonable comparisons could be made between similar methods.

\section{FINSTHIN PROCEDURE}

H. A. Einstein (1950) has presented a method for computing the bed-material discharge. The computation consists essentially of 
computing the sum of the suspended-sediment load (exclusive of wash load) that is obtained from an integration of the product of the theoretical vertical distributions of velocity and suspended sediment and the bed-load discharge, determined from the probability of particles eroding from the bed; the probability of erosion is a function of a flow parameter. Bed load is considered to be discharged through. a bed layer 2 grain diameters thick, and the suspended sediment is considered to be discharged from the water surface to the bed layer. The concentration of suspended sediment at the top of the bed layer is equated to the concentration in the bed layer, which is a function. of the bed-load discharge.

Computations are made for a representative cross section of the channel and an average energy slope. Einstein suggests that the representative cross section should be determined by averaging. the areas and the wetted perimeters of a number of sections in a typical reach that is of sufficient length to permit an adequate definition of the overall energy slope.

The reach of the Middle Loup River at Dunning extends from section $\mathrm{A}$ to section $\mathrm{E}$, a distance of about 7,950 feet. (See fig. 2.) Twenty computations of sediment discharge were made for this reach; data from one or more sections in the reach are used in each computation. Because only a limited number of cross sections were selected for this investigation, the computations did not include as many sections as recommended by Einstein to define adequately the representative cross section. However, they do show some of the characteristics of the Einstein method and some of the effects the computed representative cross section has on the computed sediment discharge.

For the 4- and 5-section Einstein computations, water-surface slopes. (assumed to be equal to energy slopes) were determined from gageheight traces of temporary recorders at sections $A$ and $E$. For the 1 - and 3-section computations, an average overall-reach slope of 0.00132 was used. For all computations, the bed-material size distribution was determined by averaging the mean distributions from the included sections (see table 4 for the mean bed-material size distribution for each section), and the representative cross sections. were determined by averaging the effective areas and the effective widths (wetted perimeters) of the included sections. Because the Einstein method is devised to compute only the bed-material discharge, the load of sediment smaller than 0.125 millimeter (wash load) was. not computed. The total load was approximated by summing the computed load and the average measured suspended-sediment load for the uncomputed fractions at the sections. The computed loads. and the comparable measured loads at section $\mathrm{D}$ are given in table 7 . 
Loads computed with data from more than one section are compared with the daily mean sediment loads at section $\mathrm{D}$, and the one-section computations are compared with instantaneous loads at section $\mathrm{D}$.

Computations other than those shown in table 7 have been made by using various combinations of sections and also by using weighting procedures in an effort to determine the best representative cross section. The four-section combination of sections $\mathrm{A}, \mathrm{B}$ (or $\mathrm{B}_{1}$ or 25 feet upstream from $B$ ), $C_{2}$, and $E$ gave the best results. The computed total loads for these 4-section combinations averaged 81 percent and ranged from 26 to 150 percent of the measured total loads. The individual percentages had a standard deviation of 49 . If percentages are considered to be distributed normally, the standard deviation indicates that about two-thirds of all similar computations will be in a range of $81 \pm 49$ percent of the measured total load. These 4-section computations include 1 wide section, 2 narrow sections, and 1 medium-width section. When only 3 sections -2 narrow and 1 of medium width-were combined, the computed total loads averaged 236 percent and ranged from 69 to 497 percent (standard deviation, 184 percent) of the measured total loads. The 5-section computation, combining data from 1 wide section, 3 narrow sections, and 1 mediumwidth section, was 190 percent of the measured total load.

These computations indicate that the Einstein method is sensitive to the computed representative cross section, at least in shallow streams (3 feet or less). For the Dunning reach, when the computed representative cross section is narrow and deep, the computed loads are too high; when it is wide and shallow, the computed loads are too low. In the 4-section computations, even though the representative cross section was weighted with 2 narrow sections (these narrow sections represent only a small percentage of the total reach length), the average computed loads were still too low. This fact suggests that the areas and widths were weighted too much with section A. Generally, flow through wide sections does not distribute evenly over the entire width, but it divides into relatively shallow and relatively deep channels. The mean depth of flow where the major part of the sediment load is discharged will ordinarily be distinctly different from that for the entire cross section. Thus, if an alluvial channel is wide and the flow is braided, computed loads based on average total areas and widths may be too low. The effect of the representative cross section on computations is emphasized by comparison of the one-section computations with the measured loads. Four computations for section $\mathrm{C}_{2}$, a very narrow section, averaged 540 percent and ranged from 139 to 1,241 percent (standard deviation, 483 percent) of the measured total loads. However, 4 computed total loads at section $\mathrm{E}$, a section with an area and width approaching those of a 
representative cross section, averaged 115 percent and ranged only from 31 to 240 percent (standard deviation, 94 percent) of the measured total load.

Total loads from the four-section and section $\mathrm{E}$ computations are plotted against comparable measured total loads in figure 24. The figure shows the lack of agreement between the computed and measured total loads even though the average percentage indicates a reasonably good comparison. Included in the figure are computed total sediment discharges for section $\mathrm{E}$ that are based on computations of bed-material discharge made by E. L. Pemberton in 1950 (written

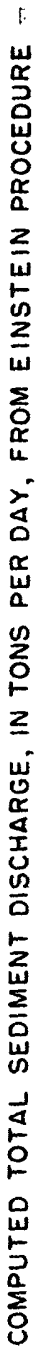

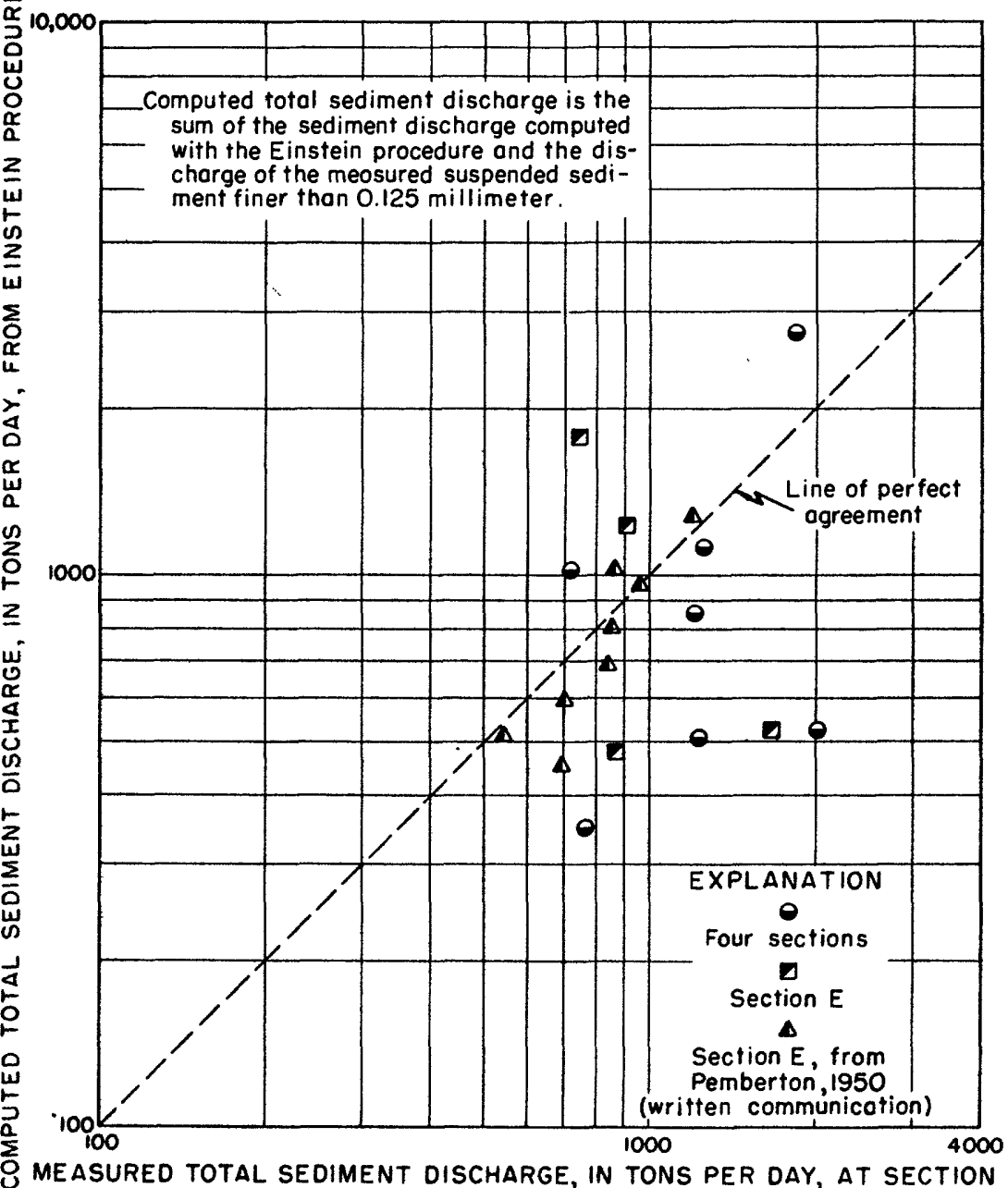

Fiavne 24.-Total sediment discharge computed from Einstein procedure plotted against measurnd total sediment discharge at section $\mathrm{D}$. 
communication). The Pemberton computations were made by using a slope of 0.00128 and a slightly different bed-material size distribution for section $\mathrm{E}$ than the one used for this report.

Comparisons of the computed loads larger than 0.125 millimeter (bed-material discharge) to the measured loads for the same fractions showed less accuracy (more percentage deviation) than the comparisons of computed total loads to the measured total loads. The 4-section computations averaged 82 percent but ranged from 13 to 167 percent (standard deviation, 64 percent) of the measured loads; the 5-section computation was 232 percent of the measured load; and the 3-section computations averaged 314 percent and ranged from 65 to 756 percent (standard deviation, 304 percent) of the measured loads. These comparisons are better indicators of the accuracy of the Einstein method than are comparisons of total loads. However, none of the comparisons are fair tests of the accuracy of the Einstein method because the number and location of the cross sections, which were selected for this investigation, did not meet Einstein's recommendations.

The size distributions of the computed loads do not compare favorably with the size distributions of the measured loads. In most of the computations the largest part of the total load was in the 0.25 - to 0.50 millimeter fraction. However, the largest part of the measured total. load was usually in the 0.125 - to 0.25 -millimeter fraction.

\section{MODIFIED EINSTEIN PROCEDURE}

A modification of the Einstein procedure for computing the total sediment discharge of an alluvial stream has been presented by Colby and Hembree (1955). The modification was developed during a study of the Niobrara River near Cody, Nebr., and is based on Einstein formulas (1950), but it differs from the Einstein procedure in four phases.

The following information from a given section at a given time is required for the computation of total load by this modified procedure: effective width, mean depth, and mean velocity of the flow; concentration and particle-size distribution of the suspended sediment in the sampled zone; particle-size distribution of the bed material; water temperature; average depth at the sampled verticals and distance from the bottom of the sampled zone to the stream bed.

\section{MODIFIED FORMULA FOR BHEAR VELOCITY}

For the modified formula the shear velocity is computed from a transposed form of equation 9 of H. A. Einstein (1950, p. 10) in which the shear velocity and hydraulic radius are the same as those given by G. H. Keulegan (1938), except the shear velocity is designated as 
$u_{m}$ and for a wide channel the hydraulic radius is replaced by the mean depth, $d$.

$$
\begin{aligned}
u_{m} & =\sqrt{(R S)_{m} g} \\
& =\frac{\bar{u}}{5.75 \log _{10}\left(12.27 \frac{d x}{k_{s}}\right)}
\end{aligned}
$$

in which-

$(R S)_{m}$ is the quantity that is obtained by solving equation a for $(R S)_{m}$ from a known numerical value of $\bar{u}$.

$g$ is the gravity constant, 32.2 feet per second per second.

$\bar{u}$ is the mean velocity, in feet per second, in the cross section and is usually from a streamflow measurement.

$x$ is a dimensionless transition parameter.

$k_{s}$ is the bed-material size, in feet, considered to be representative of bed roughness-used by Einstein (1950) as equal to $D_{65}$. where-

$D_{65}$ is the particle size at which 65 percent of the bed material by weight is finer.

Solution of equation a is by trial; $x$ is the trial factor. Plate 6 shows the relationship of $x$ to $k_{s} / \delta$ where -

in which-

$$
\delta=\frac{11.6 \nu}{u_{m}}
$$

$\delta$ is the thickness, in feet, of the laminar sublayer.

$\nu$ is the kinematic viscosity, in square feet per second.

MODIFIED FORMULA FOR COMPUTING TOTAL SUPPENDED-BHDIMENT DISCHARGE OF SOME STZE FRACTIONS

The suspended-sediment load of a size fraction moving through a cross section can be expressed by a form of Einstein's equation 33 (1950, p. 18).

in which-

$$
Q_{8}=\frac{5.75}{2.303} w u_{*} d c_{a}\left(\frac{A}{1-A}\right)^{2}\left(P J_{1}+J_{2}\right)
$$

$Q_{s}$ is the suspended-sediment discharge of a size range.

$w$ is the effective width of the cross section.

$u_{*}$ is the shear velocity.

$c_{a}$ is the concentration of sediment particles of a size fraction at a distance, $a$, above the stream bed.

$A$ is the distance of the lower limit of integration above the stream bed divided by the mean depth, $d$.

$z$ is the exponent of the equation that describes the vertical distribution of suspended sediment. 
$P$ is a parameter, and $J_{1}$ and $J_{2}$ are integrals.

$$
\begin{aligned}
& P=2.303 \log _{10}\left(30.2 \frac{d x}{k_{s}}\right) \\
& J_{1}=\int_{A}^{1}\left(\frac{1-y}{y}\right)^{z} d y \\
& J_{2}=-\int_{A}^{1}\left(\frac{1-y}{y}\right)^{z} \log _{e}(y) d y
\end{aligned}
$$

where-

$y$ is a distance above the stream bed.

Also, the equation for the concentration distribution in a vertical (Einstein, 1950, equation 29, p. 17) can be written in the form-

$$
c_{y}=c_{a}\left(\frac{d-y}{y}\right)^{2}\left(\frac{A}{1-A}\right)^{2}
$$

in which-

$c_{y}$ is the concentration of sediment particles of a size fraction at the distance, $y$, above the stream bed.

For any given distance, $a, c_{a}[A /(1-A)]^{2}$ is necessarily constant. Thus-

$$
\frac{5.75}{2.303} w u_{*} d c_{\mathrm{a}}\left(\frac{A}{1-A}\right)^{2}=K
$$

in which-

$K$ is a constant.

By substitution-

$$
Q_{s}=K\left(P J_{1}+J_{2}\right)
$$

If a single prime mark designates association with the sampling depth and a double prime mark designates association with the total depth through which suspended sediment is discharged, the ratio of the measured suspended sediment of a size fraction discharged through the sampling zone, $Q_{s}{ }^{\prime}$, to the suspended sediment of the size fraction discharged through the total depth, $Q_{s}{ }^{\prime \prime}$, can be transposed and expressed by-

$$
Q_{a}^{\prime \prime}=Q_{s} \frac{\left(P J_{1}^{\prime \prime}+J_{2}^{\prime \prime}\right)}{\left(P J_{1}^{\prime}+J_{2}^{\prime}\right)}
$$


MODIFIED FORMULAS FOR THE EXPONENT $\boldsymbol{z}$

In the modified procedure, computations of the total sediment discharge can be made with a $z$ determined for each size range by any 1 of 4 different methods; however, computations are generally made with a $z$ called $z_{2}$.

In accordance with equation c, $c_{y}$ versus $(d-y) / y$ plotted on logarithmic coordinate paper establishes $z_{1}$ for a given size fraction. ( $z_{1}$ is the slope of the line.)

Figure 25 shows $z_{1}$ plotted against $z_{m}$ where $z_{m}$ equals $V_{s} / 0.4 u_{m}$. At a given cross section and time, $0.4 u_{m}$ is a constant; thus, the slope of a line defined by any individual set of $z_{1}$ 's shows the variation of that set with $V_{\mathrm{s}}$, the fall velocity of the geometric mean particle size of a size range. The average of all the slopes indicates that $z_{1}$ is proportional to the 0.7 power of the fall velocity when $V_{s}$ is from Rubey's equation (1933).

$Q_{8}{ }^{\prime \prime}$ can be computed from Einstein's equation $61(1950$, p. 40$)$ if the equation is written as-

$$
Q_{\mathrm{g}}{ }^{\prime \prime}=i_{B} Q_{B}\left(P I_{1}{ }^{\prime \prime}+I_{2}{ }^{\prime \prime}\right)
$$

in which-

$i_{B} Q_{B}$ is the bed-load rate for the entire width (sediment discharge, in tons per day, through the bed layer of particles of a size fraction).

$I_{1}{ }^{\prime \prime}$ is a mathematical abbreviation that contains $J_{1}{ }^{\prime \prime}$.

$$
\begin{aligned}
I_{1}^{\prime \prime} & =0.216 \frac{A^{2-1}}{(1-A)^{2}} J_{1}^{\prime \prime} \\
& =K_{1} J_{1}^{\prime \prime}
\end{aligned}
$$

$I_{2}{ }^{\prime \prime}$ is a mathematical abbreviation that contains ${J_{2}}^{\prime \prime}$ and is negative.

where-

$$
\begin{aligned}
I_{2}^{\prime \prime} & =0.216 \frac{A^{z-1}}{(1-A)^{2}} J_{2}^{\prime \prime} \\
& =K_{1} J_{2}^{\prime \prime}
\end{aligned}
$$

$K_{1}$ is a constant for a given section and time and equals $I_{1}{ }^{\prime \prime} / J_{1}{ }^{\prime \prime}$ or $I_{2}{ }^{\prime \prime} / J_{2}^{\prime \prime}$.

This equation combined with equation d gives-

$$
\frac{Q_{s}^{\prime}}{i_{B} Q_{B}}=\frac{\left(P I_{1}^{\prime \prime}+I_{2}^{\prime \prime}\right)\left(P J_{1}^{\prime}+J_{2}^{\prime}\right)}{\left(P J_{1}^{\prime \prime}+J_{2}^{\prime \prime}\right)}
$$




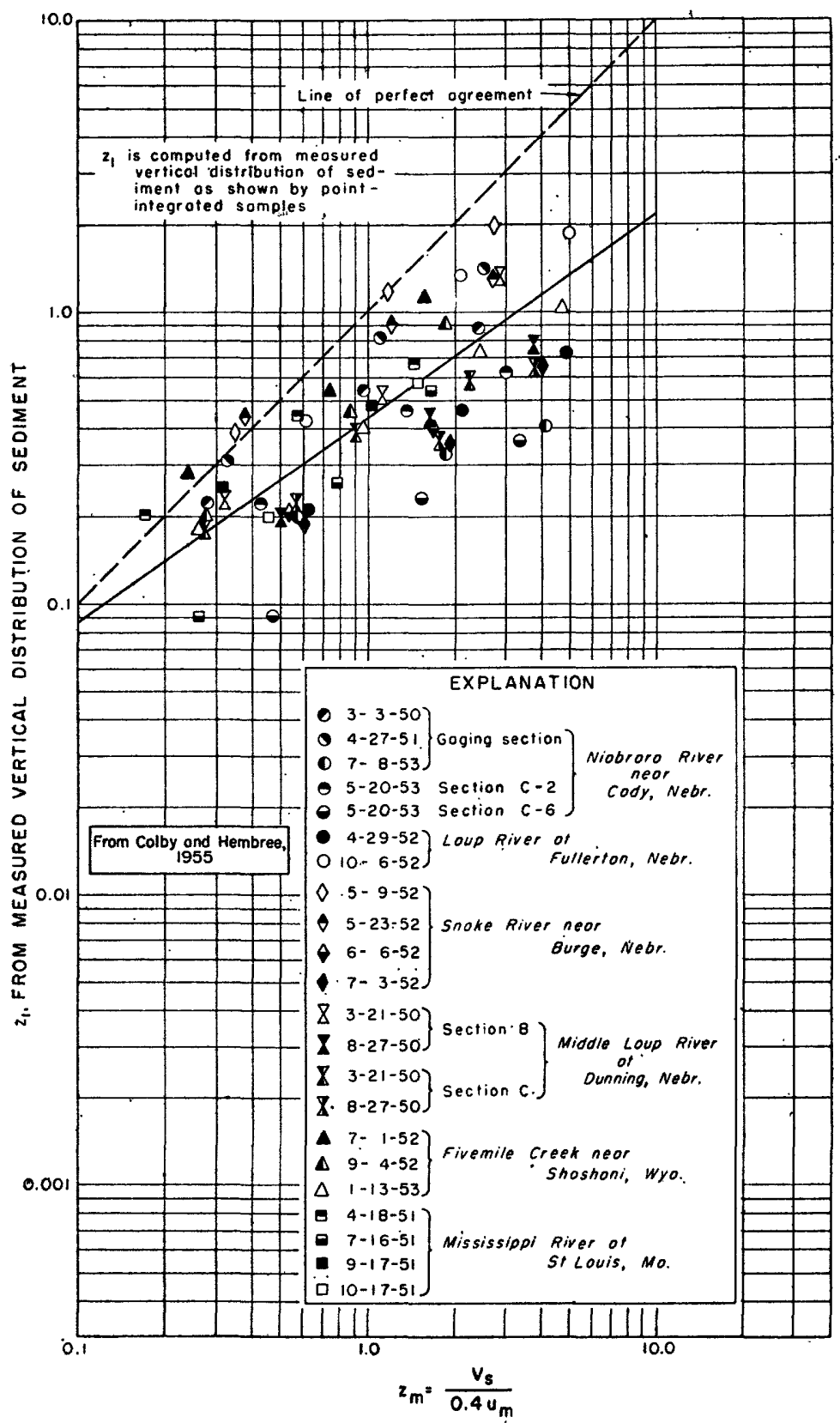

Figori 25.- $z_{1}$ plotted against $z_{m}$. 
or-

$$
\begin{aligned}
\frac{Q_{\mathrm{B}}^{\prime}}{i_{B} Q_{B}} & =\frac{I_{1}^{\prime \prime}}{J_{1}^{\prime \prime}}\left(P J_{1}^{\prime}+J_{2}^{\prime}\right) \\
& =\frac{I_{2}^{\prime \prime}}{J_{2}^{\prime \prime}}\left(P J_{1}^{\prime}+J_{2}^{\prime}\right)
\end{aligned}
$$

Equation $f$ is given by Colby and Hembree (1955, equation $C$ ) for computing $z_{2}$. Because $Q_{\mathrm{s}}^{\prime}$ and $i_{\mathrm{B}} Q_{\mathrm{B}}$ are computed independently of $z$, only one numerical value for $z$ will determine $I$ and $J$ quantities to satisfy equation $f$.

$A z_{3}$ can be computed from $Q_{s}{ }^{\prime}$ and $Q_{s}{ }^{\prime \prime \prime} . Q_{s}{ }^{\prime \prime \prime}$ is the measured total sediment discharge of a size fraction for the entire width. Einstein's equation $63(1950$, p. 40$)$ can be written in the form-

$$
Q_{\mathrm{B}}{ }^{\prime \prime \prime}=i_{B} Q_{B}\left(P I_{1}^{\prime \prime}+I_{2}{ }^{\prime \prime}+1\right)
$$

Eliminating $i_{B} Q_{B}$ by use of equation e-

$$
\frac{Q_{s}^{\prime}}{Q_{s}^{\prime \prime \prime}}=\frac{\left(P I_{1}^{\prime \prime}+I_{2}^{\prime \prime}\right)\left(P J_{1}^{\prime}+J_{2}{ }^{\prime}\right)}{\left(P I_{1}^{\prime \prime}+I_{2}{ }^{\prime \prime}+1\right)\left(P J_{1}^{\prime \prime}+J_{2}^{\prime \prime}\right)}
$$

Only one $z_{3}$ will give $I$ and $J$ quantities that will satisfy equation $\mathbf{h}$ with a given $Q_{s}^{\prime}$ to $Q_{s}{ }^{\prime \prime \prime}$ ratio.

Colby and Hembree (1955) have designated a $z$ from an empirical equation as $z_{4}$. They have used the equation $z_{4}=4.6\left(V_{8}\right)^{0.7}$; however, they point out that an equation of this type does not contain any parameter of flow or turbulence and is not likely to be generally applicable to streams other than the one for which it was defined.

MODIFIED FORMULAS FOR FLOW AND BED-LOAD TRANSPORT INTENGITIES

Einstein's equation $54(1950$, p. 37$)$ defines the flow intensity for a size fraction by-

in which-

$$
\Psi_{*}=\xi Y\left(\beta / \beta_{x}\right)^{2} \Psi
$$

$\xi$ is a hiding factor of grains in a mixture and decreases to 1.0 for particle sizes large enough to make $D / X$ greater than 1.5 . $Y$ is a pressure correction in the transition from smooth to rough flow and is a function of $k_{s} / \delta$.

$\beta$ is equal to $\log _{10}(10.6)$.

$\beta_{x}$ is equal to $\log _{10}\left(10.6 X x / k_{s}\right)$.

$\Psi$ is a function for correlating the effect of the flow with the intensity of bed-load transport. where-

$D$ is the geometric mean size, in feet, of a size fraction.

$X$ is the characteristic grain size of the bed mixture. 
For the modified procedure, $\Psi$ is from Einstien's equation 49 (1950, p. 36); however, $(R S)_{m}$ is substituted for $R^{\prime} S_{\ell}$.

$$
\Psi=\left(S_{s}-1\right) \frac{D}{(R S)_{m}}
$$

in which-

$S_{s}$ is the specific gravity of the solid sediment particles.

A flow intensity computed with the substitution in the $\Psi$ equation does not have the same numerical value as a flow intensity computed with the original Einstein equation. Many numerical values for $Y\left(\beta / \beta_{x}\right)^{2}$ were computed by Colby and Hembree (1955); they ranged from 0.3 to 0.6 and averaged about 0.4 . Combining the 0.4 with the modified equation for $\Psi$ gives an average equation of the flow intensity for particle sizes for which $\xi$ is equal to 1 (Colby and Hembree, 1955, equation I).

$$
\Psi_{m}=0.4\left(S_{s}-1\right) \frac{D}{(R S)_{m}}
$$

For the particle sizes small enough for $\xi$ to be greater than 1.0, a function different from equation $\mathrm{i}$ had to be selected. The selected equation was Einstein's equation $11(1950$, p. 10), which for the modified procedure (Colby and Hembree, 1955, equation $\mathrm{H}$ ), becomes-

in which-

$$
\Psi_{m}=\left(S_{s}-1\right) \frac{D_{35}}{(R S)_{m}}
$$

$D_{35}$ is the particle size, in feet, at which 35 percent of the bed material by weight is finer.

In a computation of the load of a size fraction, the larger $\Psi_{m}$ from equations $i$ and $j$ is used. Thus, a $\Psi_{m}$ from equation $j$ is always used for particle sizes smaller than $2.5 D_{35}$, and for all such sizes $\Psi_{m}$ is a oonstant.

This application of equations $i$ and $j$ is somewhat analogous to Einstein's use of $\xi$. Equation i replaces the part of the curve in Einstein's figure 7 (1950) for which $\xi$ equals 1.0, and equation j replaces the part for which $\xi$ is greater than 1.0. Use of equation $j$ gives a flow intensity that does not change with particle size. A constant flow intensity for the smaller particle sizes could be computed from Einstein's equation $54(1950$, p. 37$)$ if the $\xi$ versus $D / X$ curve had a slope of 1.0 for values of $D / X$ less than 1.0. Colby and Hembree (1955, fig. 44) illustrate that when $z$ is considered to be proportional to the 0.7 power of the fall velocity, the $\xi$ versus $D / X$ curve does have an average slope of about 1.0. 
Flow intensities computed as $\Psi_{m}$ are different from those computed as $\Psi_{*}$. However, for the modified procedure, $\Psi_{m}$ is used for $\Psi_{*}$, and the $\Phi_{*}$ determined from the $\Psi_{*}$ versus $\Phi_{*}$ curve (Einstein, 1950, fig. 10) is divided by two to obtain the intensity of bed-load transport. A $z_{2}$ determined from an $i_{B} Q_{B}$ that is computed from $\Phi_{*} / 2$ has about the same numerical value as a comparable $z_{3}$. Also, a load computed with such a $z_{2}$ is comparable to the measured total load.

\section{COMPUTATION PROCEDURE}

Colby and Hembree (1955) have presented an explanation of the total load computation procedure; however, a brief explanation is presented here to review the essentials of the procedure. A sample total load computation based on information from measurements of water and sediment discharges made on December 14, 1950, at 3:30 p. $\mathrm{m}$. is shown in plate 7 . This sample computation is merely for illustration, and none of the numerical values are referred to in the following step-by-step explanation.

The computation form (pl. 7) is separated into four major computation blocks, which are headed: block I, preliminary data and computations; block II, computation of $i_{B} Q_{B}$; block III, computation by $z_{2}$; and block IV, computation by $z_{x}$.

Step 1.-Fill in line 1, block I, with the basic data in pound-footsecond units; $w$, effective width; $\bar{u}$, mean velocity; $d$, mean depth; $d_{s}$, average depth at the verticals sampled; $D_{65}\left(\right.$ or $k_{s}$ ) and $D_{35}$, particle size at which 65 and 35 percent, respectively, of the bed material by weight is finer; Conc, measured suspended-sediment concentration (in parts per million); $Q_{s M}$, measured suspended-sediment discharge (in tons per day); and Temp, water temperature in degrees Fahrenheit. (The English system of units is used throughout the computation.)

Step 2.-Solve the converted form of equation a, line 2, block I, for $\sqrt{(R S)_{m}}$ after assuming a trial $x$.

Step 3.-Compute $(R S)_{m}$ from the $\sqrt{(R S)_{m}}$ determined by step 2.

Step 4.-Compute the shear velocity, $u_{m}$, from $\sqrt{(R S)_{m} g}$, in which $\sqrt{(R S)_{m}}$ is from step 2 and $g$ is the gravity constant, 32.2 feet per second per second.

Step 5.-Compute $\delta$ from equation b, in which $\nu$ is the kinematic viscosity, in square feet per second, at the indicated water temperature and $u_{m}$ is from step 4. Tables or graphs of the kinematic viscosity of water are given in most text books on fluid mechanics and engineering handbooks.

Step 6.-Calculate $k_{s} / \delta$ and enter plate 6 for $x$. If the trial $x$ is not about the same as the $x$ from the plate, repeat steps 2 through 6 .

Step 7.-Solve for $P,($ p. 48) on line 3 . 
Step 8.-Determine $A^{\prime}$, on line 4 , from $A^{\prime}=d_{n} / d_{s}$, in which $d_{n}$ is the vertical distance, in feet, not sampled; that is, the distance from the bottom of the sampled zone to the stream bed.

Step 9.-From fig. 26, find the percentage of flow in the sampled zone by using the computed $A^{\prime}$ and $P$.

Step 10.-Compute the load in the sampled zone $\left(Q_{t s}{ }^{\prime}\right)$ by multiplying the percentage of flow in the sampled zone by the measured suspended-sediment discharge $\left(Q_{s M}\right)$.

Step 11.-List the percentage of measured suspended sediment in each size range under the geometric mean size of the range (line 5) on line 6 if the percentages were determined from an actual size analysis or on line 7 if they were determined by some other means. Line 8 is not completed unless the size distribution of the measured total load is known and is to be used in checking the accuracy of the computed total load.

Step 12.-List in column 1, block II, each geometric mean size of the size ranges that have appreciable bed-load discharge $\left(i_{B} Q_{B}\right)$.

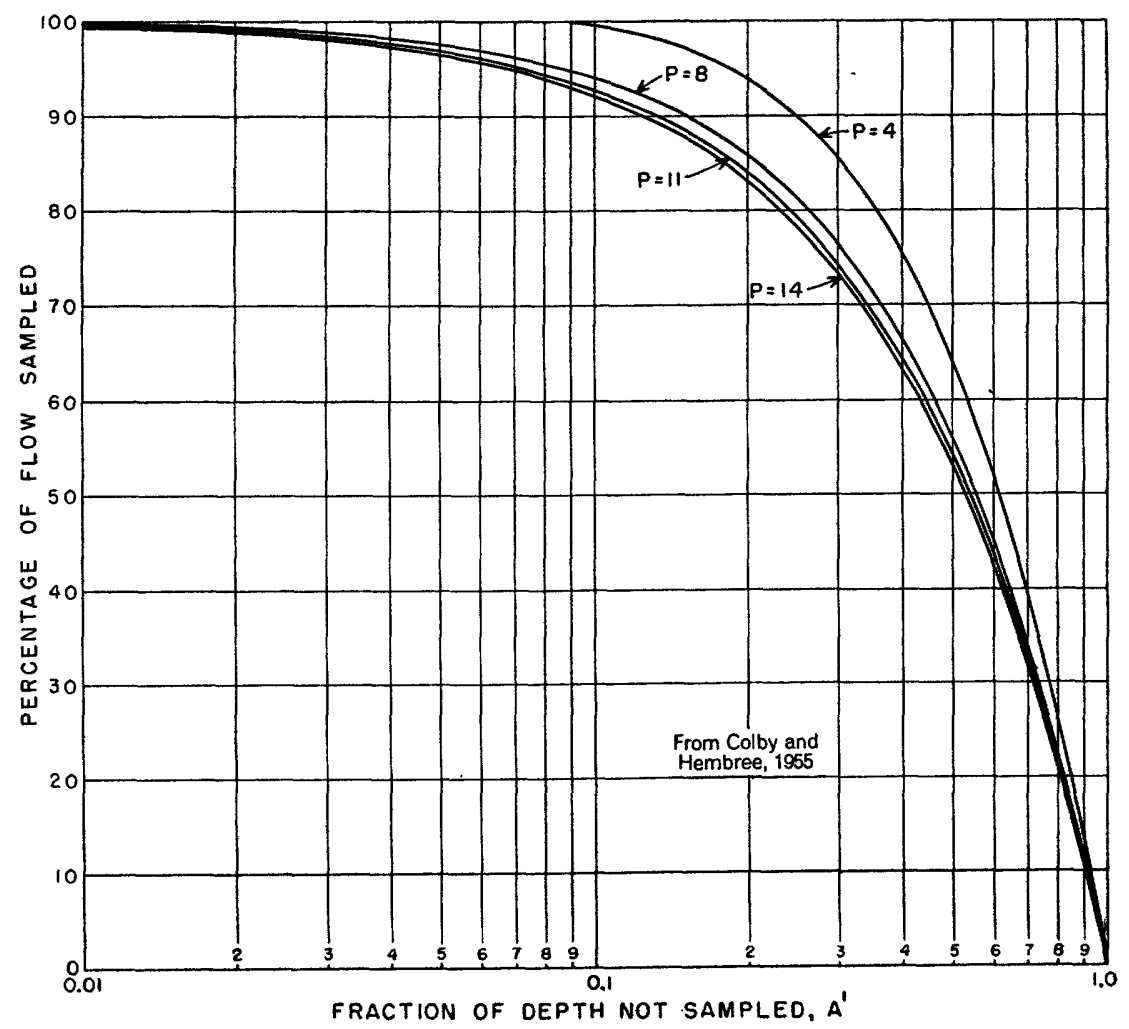

FTGURE 26.-Vertical distribution of streamflow. 
Step 13.-Compute a $\Psi_{m}$ for each size range, first by equation $i$ and then by equation j. List the larger $\Psi_{m}$ in each size range in column 2 .

Step 14.-Determine the $\Phi_{*}$ for each size range from plate 8 by using $\Psi_{m}$ in column 2 in place of $\Psi_{*}$. Divide each $\Phi_{*}$ by 2 and enter the quotients in column 3 .

Step 15.-Einstein (1950, step 34, p. 59$)$ has defined $i_{B} q_{B}$, the sediment discharge in pounds per second per foot of width through the bed layer of particles of a size fraction, as the product of the intensity of bed-load transport, $i_{b}, s_{s}, g^{3 / 2}, D^{3 / 2}$, and $\left(S_{s}-1\right)^{1 / 2}$. For the modified method this equation may be written as-

$$
i_{B} q_{B}=\frac{\Phi_{*}}{2} i_{b} s_{s} g^{3 / 2} D^{3 / 2}\left(S_{s}-1\right)^{1 / 2}=1,200 i_{b} D^{3 / 2} \frac{\Phi_{*}}{2}
$$

in which-

the intensity of bed-load transport is represented by $\Phi_{*}$ in the Einstein method and by $\Phi_{*} / 2$ in the modified method. The intensity of bed-load transport is dimensionless.

$i_{b}$ is the fraction by weight of bed material in a size range.

$s_{s}$ is the mass density of the sediment and equals the product of

2.65 and 1.94 slugs per cubic foot (5.14 slugs per cubic foot).

$S_{s}$ is the specific gravity of the sediment (2.65).

List the value of $1,200 D^{3 / 2}$ for each size range in column 4 . $D$ is the geometric mean size of the size range.

Step 16.-Enter the fraction of bed material in each size range $\left(i_{b}\right)$ in column 5 .

Step 17.-Compute $i_{B} q_{B}$ for each size range from equation $\mathrm{k}$ in step 15 and list in column 6.

Step 18.- Compute the constant $43.2 w$ for entry in column 7 . This $w$ is the effective width, and 43.2 is a constant converting pounds per second to tons per day.

Step 19.-Compute $i_{B} Q_{B}$ for each size range and enter in column 8. $i_{B} Q_{B}$ is the product of $i_{B} q_{B}$ and $43.2 w$.

Step 20.-List in column 9, block III, the geometric mean size of all the size ranges that are transported. (Column numbers for blocks III and IV are at the bottom of block IV.)

Step 21.-Compute the load in the sampled zone of each size range $\left(Q_{s}{ }^{\prime}\right)$ as the product of the load in the sampled zone $\left(Q_{t s}{ }^{\prime}\right)$ (line 4, block $I)$ and the percentage of measured suspended sediment in each size range (from lines 6 or 7 , block $I$ ). If the percentages from line 6 are used, enter the product in column 10; if from line 7, enter the product in column 11.

Step 22.-Copy in column 12 each $i_{B} Q_{B}$ from column 8, block II. 
Step 23.-Compute $A^{\prime \prime}$ for each size range from $A^{\prime \prime}=2 D / d$ and enter in column 15. $A^{\prime \prime}$ is equal to the distance of the lower limit of integration above the stream bed, $a$, divided by $d$. Einstein (1950, p. 25) shows the relation, $a=2 D$.

Step 24.- The large box, headed "Determination of reference $z_{2}$," in block III is used in this step. Select the reference size. The reference size should be the geometric mean size of a size range that is represented in appreciable quantitites in both bed-load discharge and suspended-sediment discharge. For streams in which the bedload discharge is a substantial part of the total load, the reference size range ordinarily will be the range that has the greatest total sediment discharge. Once the reference size is selected, it can be used for all subsequent computations. Compute the value of the ratio $Q_{s}{ }^{\prime} / i_{B} Q_{B}$ (left-hand side of equation $\mathrm{f}$ ) for the reference size. Assume a $z_{2}$ for the reference size (fig. 27 will aid in a first approximation for many shallow streams) and solve the right-hand side of equation $\mathrm{f}$ with values from plates 9,10 , and 11 , using $A^{\prime}$ and $A^{\prime \prime}$ with the assumed $z_{2}$ of the reference size. When the right and left sides of the equation balance, the assumed $z$ is the proper $z_{2}$ for the reference size range.

Step 25.-Because $z$ varies with about the 0.7 power of fall velocity and because flow characteristics that might cause $z$ to vary are constant at a given cross section and time, the $z_{2}$ for the other size ranges can be computed by proportion from the $z_{2}$ for the reference size range.

$$
z_{2 u}=z_{2 r}\left(\frac{V_{s u}}{V_{s r}}\right)^{0.7}
$$

in which-

$z_{2 u}$ is the unknown and required $z_{2}$ for a size range.

$z_{2 r}$ is the known $z_{2}$ for the reference range.

$V_{s u}$ is the fall velocity of the geometric mean size of the range requiring the $z_{2}$.

$V_{s r}$ is the fall velocity of the geometric mean size of the reference range.

Curves for the different size ranges of $\left(V_{s u} / V_{s t}\right)^{0.7}$ (called multipliers) versus temperature are plotted on plate 12 ; the 0.125 - to 0.25 -millimeter size range is the reference range. The $z_{2}$ for any size range is the product of the $z_{2}$ for the reference range and the multiplier at the indicated water temperature for the size range. List in column 13 the multiplier for each size range.

Step 26.-Compute the $z_{2}$ for all size ranges from the $z_{2}$ for the reference range and the multiplier. (See equation $\mathrm{m}$.) 


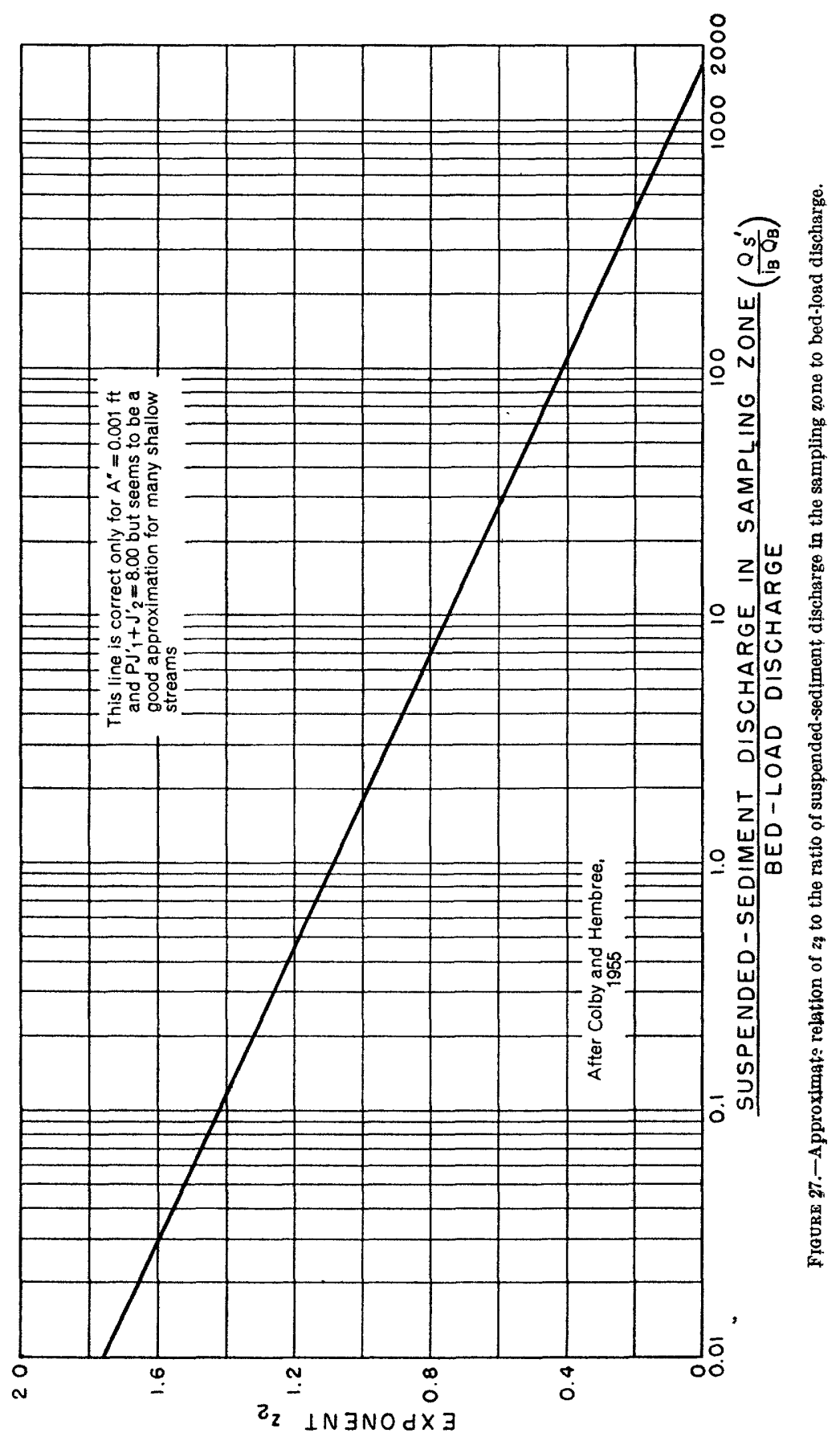


Step 27.-Complete columns 16, 17, 18, and 19 for the size ranges where the $z_{2}$ is less than about 0.9 ; use plates 9 and 10 and the $z_{2}, A^{\prime}$, and $A^{\prime \prime}$ for each size range.

For low values of $z$, variations of $z$ result in low rates of change in $P J_{1}^{\prime \prime}+J_{2}{ }^{\prime \prime}$ and high rates of change in $P I_{1}^{\prime \prime}+I_{2}{ }^{\prime \prime}$. For high values of $z$, variations of $z$ result in the reverse. For a $z$ of about 0.9 , the rate of change in $P J_{1}{ }^{\prime \prime}+J_{2}^{\prime \prime}$ and $P I_{1}{ }^{\prime \prime}+I_{2}{ }^{\prime \prime}$ is about equal. Either equation $d$ or equation $g$ can be used to compute the total load of a size fraction. (Any appreciable values of $i_{B} Q_{B}$ must be added to values from equation $d$ for the total load.) If $z$ is less than 0.9 , the load should be computed with equation d; if $z$ is greater than 0.9 , the load should be computed with equation $\mathrm{g}$. When $z_{2}$ is used, the $z_{2}$ for the reference size is determined by using both $P J_{1}^{\prime \prime}+J_{2}^{\prime \prime}$ and $P I_{1}{ }^{\prime \prime}+I_{2}{ }^{\prime \prime}$. (See equation e.) Therefore, loads computed for the reference size with either equation $d$ or $g$ will be about the same.

Step 28.-Compute the ratio $\left(P J_{1}^{\prime \prime}+J_{2}^{\prime \prime}\right) /\left(P J_{1}^{\prime}+J_{2}^{\prime}\right)$ (equation d) from $P$ (line 3 , block $\mathrm{I}$ ) and the information computed in step 27. $J_{2}$ is always negative. List the ratios in column 20 .

Step 29.-Complete columns 21 and 22 for all size ranges for which no $J$ was determined; use plates 11 and 13 and the $z_{2}$ and $A^{\prime \prime}$ for each size range.

Step 30.-Compute $P I_{1}{ }^{\prime \prime}+I_{2}{ }^{\prime \prime}+1$ (equation g) for entry in column 23 from $P$ and the information in columns 21 and $22 . I_{2}^{\prime \prime}$ is always negative.

Step 31.-Compute the total sediment discharge of all the size ranges for which $J$ quantities were determined; it is the product of the values in column 20 and in column 10 or 11 (see equation d) plus any appreciable values of $i_{B} Q_{B}$. Enter the total sediment discharge in the appropriate column-either 24 or 25.

Step 32.-Compute the total sediment discharge of all the size ranges for which $I$ quantities were determined; it is the product of the values in columns 12 and 23. (See equation g.) Enter the total sediment discharge in either column 24 or 25 .

Whenever any type of $z$ other than $z_{2}$ is used in the computation, steps 20 through 24 are altered. An example using a $z_{x}$ will be explained in the following steps. The symbol $z_{x}$ is used to represent either $z_{1}, z_{3}$, or $z_{4}$.

Step 20a.-Compute $z_{x}$ for the reference size according to the information on pages 49 to 51 . (See explanation of reference size in step 24.)

Step 21a.-List in column 9, block IV, the geometric mean size of all the size ranges of sediment that are transported.

Step 22a.-Compute and enter $Q g^{\prime}$ for each size range according to step 21 . 
Step 2Sa.-Compute $A^{\prime \prime}$ for each size range according to step 23 and enter the values in column 15 , block IV.

Step 24a.-The large box, headed "Determination of reference $z_{x}$ and comparable $i_{B} Q_{B}$," in block IV is used in this step. For a given $z_{x}, A^{\prime \prime}, A^{\prime}$, and $Q_{s}^{\prime}$, only one $i_{B} Q_{B}$ will satisfy equation $f$. In other words, at a given cross section and time and for a given $z_{x}$, only one $i_{B} Q_{B}$ will reproduce the measured suspended sediment in the sampled zone. (For the reference size, if the $z_{x}$ is the same as the computed $z_{2}$, the computed $i_{B} Q_{B}$ will be the same as the $i_{B} Q_{B}$ in column 8 , block II.) Solve directly for $i_{B} Q_{B}$ of the reference size; use equation $\mathrm{f}$ and the reference size $Q_{s}{ }^{\prime}, z_{x}, A^{\prime \prime}$, and $A^{\prime}$. Enter the value in column 12 , block IV.

Step 25a.-Proportion each $i_{B} Q_{B}$ listed in column 8, block II, in the same proportion as that between the $i_{B} Q_{B}$ computed in step $24 \mathrm{a}$ and the $i_{B} Q_{B}$ listed for the reference size in column 8 , block II. Enter the value of each proportioned $i_{B} Q_{B}$ in column 12, block IV.

Step 26a.-Continue as before, starting with step 25.

Ideally, the total sediment discharge would be computed by summing the sediment discharges through increments of width, throughout each of which all the various hydraulic parameters are constant. However, if computations are made for sections or parts of sections through which the velocities are fairly uniform laterally, the results will be satisfactory because lateral changes in velocity have more effect on the total load computations than lateral changes in other parameters-particularly if the velocities are less than 1.5 feet per second. Colby and Hembree (1955) advise avoiding sections in which a large percentage of the cross-sectional area has flow at velocities of generally less than 1.5 feet per second. However, they suggest that the total sediment discharge of such sections can be computed by summing the individual sediment discharge of segments of the cross section; the flow in each segment should have relatively constant velocities.

\section{COMPUTATIONS BY THE MODHFIED GINSTEIN PROCEDURE}

Sixty-three total sediment discharges for the selected river sections were computed with the modified Einstein method. The loads, by individual size fractions, computed for each section and time are listed and compared with the measured loads at section $D$ (at comparable times) in table 8 . The computed total loads ranged from 64 to 166 percent and averaged 112 percent of the measured total load. The standard deviation of the 63 individual percentages was 22 percent. Thus, if an infinite number of similar computations were made and the computed loads were expressed as percentages of the measured total load, roughly two-thirds of the percentages

$468443-59-6$ 
would be within \pm 22 percent of the mean percentage, and the chances are 19 out of 20 that the mean percentage would be within a range of 107 to 117 percent of the measured total load. A comparison between the computed total load and the measured total load is shown on figure 28. The discontinuous dashed lines indicate the computed total load in percentage of the measured total load. The 112 percent is an unweighted average of the individual percentages. However, if computations are made to determine a continuous accumulation of sediment, a weighted average is more representative of the accuracy of the method. The sum of the computed total sediment loads was

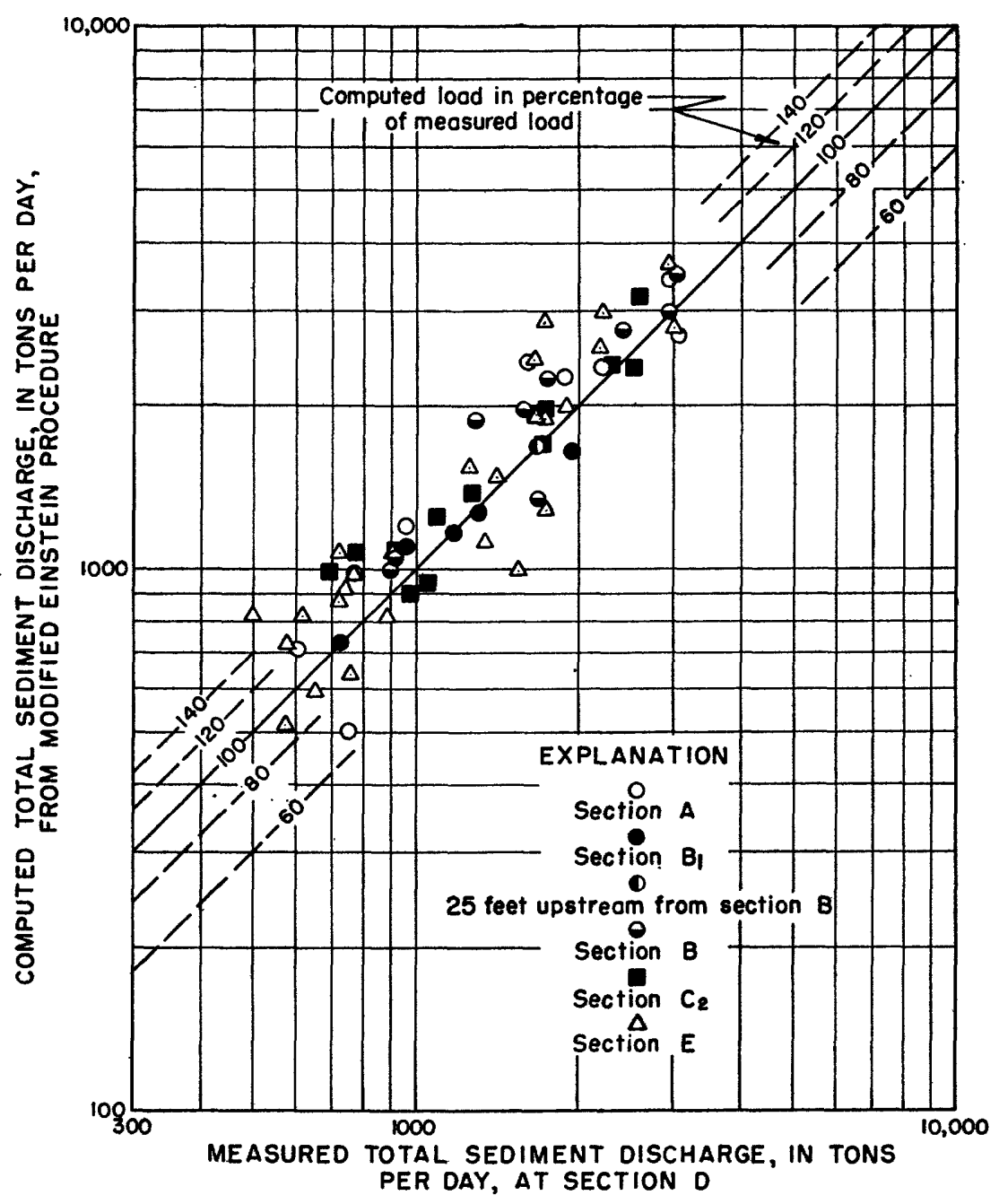

FioUR: 28.-Computed sediment discharge from modifled Einstein procedure plotted against measured total sediment discharge at section $\mathrm{D}$. 
111 percent of the sum of the measured total sediment loads at the turbulence flume at comparable times.

In this report, the following information from each section was used for the computations of total sediment discharge: The average bed-material size distribution that was determined from all available samples, other than special samples, collected at the section; the measured suspended-sediment concentration and size distribution; the measured sediment discharge computed from the rated water discharge, except when the load was computed by parts; multipliers based on fall velocities from Rubey's equation. Most of the computed total loads for section $A$ and some of the computed total loads for section $\mathrm{E}$ were determined from individual computations for each of two parts or more of the section. The procedure of computing the total sediment discharge at a section by parts usually improved the agreement between the computed and the measured total loads.

\section{STRAUB EQUATION}

L. G. Straub (U. S. Cong., 1935) developed, for various flow conditions, a series of equations from the original formula by P. du Boys. The Du Boys formula is based on the ideas that bed sediment is moved by a shear, or tractive, force created by the component in the direction of flow of the weight of water above the bed and that there is a critical shear at which general movement will begin. The formula is intended to compute the discharge of sediment that moves along or near the bed. A form of Straub's equation 8 (U. S. Cong., 1935, p. 1135) was selected for this report.

$$
G=43.2 \theta S^{2}\left[\Sigma w d\left(d-d_{o}\right)\right]
$$

in which-

$G$ is the sediment discharge, in tons per day.

43.2 is a constant for converting pounds per second to tons per day.

$\theta$ corresponds to Straub's $\Psi$, the transportation characteristic, in pounds per cubic foot per second.

$S$ is the slope of the energy gradient and in this report is considered to be equal to the slope of the water surface.

$d_{o}$ is the minimum depth at which bed sediment will move and whereequals $\tau_{c} / \gamma S$.

$\tau_{c}$ is the critical tractive force, in pounds per square foot, at which general sediment movement begins.

$\gamma$ is the specific weight of water and equals 62.4 pounds per cubic foot.

$468443-59-6$ 
Straub determined the following values for $\theta$ and $\tau_{c}$ :

$\begin{array}{ccc}\begin{array}{c}\text { Mean diameter, in } \\ \text { millimeters, of } \\ \text { bed material }\end{array} & \theta & \tau_{c} \\ 0.125 & 523,000 & 0.0162 \\ .25 & 312,000 & .0172 \\ .50 & 187,000 & .0215 \\ 1.0 & 111,000 & .0316 \\ 2.0 & 66,200 & .0513 \\ 4.0 & 39,900 & .089\end{array}$

Values of $\theta$ and $\tau_{c}$ for the median diameter of bed material were determined for use in the computations in this report from graphs of $\theta$ and $\tau_{c}$ versus particle size that were based on the above table. The sediment load was determined by summing $w d\left(d-d_{o}\right)$ for about 30 subsections of the cross section.

Loads from computations for section $\mathrm{E}$ are shown with other pertinent data in table 9. Comparisons show that the computed loads are generally much too high and that they are, on the average, about twice the measured total loads at section $D$. The equation seems to be more suitable for deep streams or shallow streams that have flat gradients than for streams that have hydraulic characteristics like those of the Middle Loup River.

\section{KAITNSKE EQUATION}

A. A. Kalinske (1947) has developed an equation for computing the bed-load discharge of unigranular material. The basis for the equation is that the bed-load discharge is equal to the product of the average velocity of the particles, the weight of each particle, and the number of particles. From an analysis of the turbulent variations in stream velocity in the zone of bed-load movement, the average particle velocity is related to the ratio of the critical tractive force (or critical shear) to the total shear. The product of the particle weight and number simplifies to the product of a constant, the specific weight of a particle, and the part of the bed area taking shear. Kalinske also presented a method for adapting the equation to sand mixtures. In the adaption, the load of each size range is computed independently, and the part of the bed taking shear for each size range is expressed as a proportion of the whole bed area taking shear. In this report, a form of Kalinske's equation 10a is used for sand mixtures.

$$
g_{b}=43.2 w u_{*} \gamma_{\theta} D p_{i} 7.3\left(\bar{U}_{g} / \bar{U}\right)
$$


in which-

$g_{b}$ is the bed-load discharge, in tons per day, for a size range.

43.2 is a constant for converting pounds per second to tons per day.

$u_{*}$ is the shear velocity, in feet per second, and equals $\sqrt{d S g}$ for wide channels.

$\gamma_{\theta}$ is the specific weight of sediment particles, in pounds per cubic foot.

$D$ is the mean particle-size diameter, in feet, of a size range and in this report is used as the geometric mean.

$p_{i}$ is the part of the bed area occupied by the particles in the size range and is equal to $p\left(i_{b} / D\right) / m$.

7.3 is a constant.

$\bar{U}_{\theta} / \bar{U}$ is the ratio of the mean speed of movement of the particles of a size range to the mean velocity of flow at the grain level and is a function of $\tau_{c} / \tau_{0}$ for constant values of $r$, the relative intensity of turbulence. (Fig. 29 is used to obtain $\bar{U}_{g} / \bar{U}$ from $\left.\tau_{c} / \tau_{o}.\right)$

where-

$p$ is the part of the bed area taking shear and has experimentally been shown to equal 0.35 for unigranular material.

$m$ is the summation of all values of $i_{b} / D$ for the various size ranges that compose the bed.

$\tau_{o}$ is the total shear at the bed and equals $\gamma d S$.

The total bed-load discharge, $G_{b}$, is the sum of the $g_{b}$ for each size range in the bed.

The results of 17 computations for section $\mathrm{E}$ by the Kalinske equation are given in table 9. Computed discharges seem to be in the proper order of magnitude; however, the range of the discharges for the different hydraulic conditions was relatively small. In general, low discharges were associated with high total sediment discharges and high unmeașured sediment discharges, and high discharges were associated with low total sediment discharges and low unmeasured sediment discharges. In addition, figure 30 , which is a graph of the concentration of measured suspended sediment coarser than 0.125 millimeter plotted against computed bed-load discharge, shows that low discharges are associated with high concentrations and that high discharges are associated with low concentrations. According to the equations for the vertical distribution of sediment and the relationships between bed-load discharge and suspended-sediment concentration presented by Einstein (1950), the concentration of suspended bed-material load and the concentration of the measured suspended bed-material load will generally increase as bed-load discharge increases. 


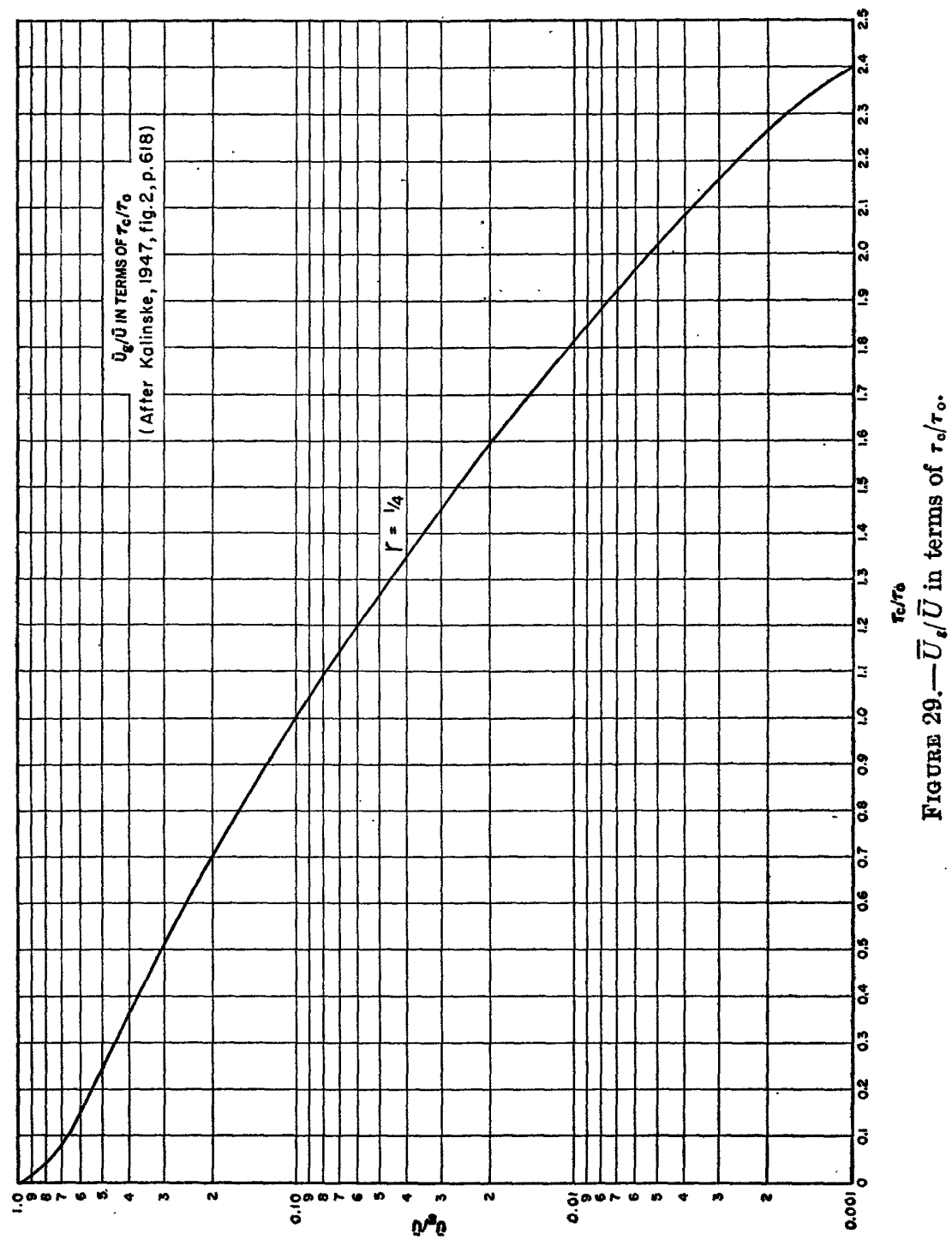




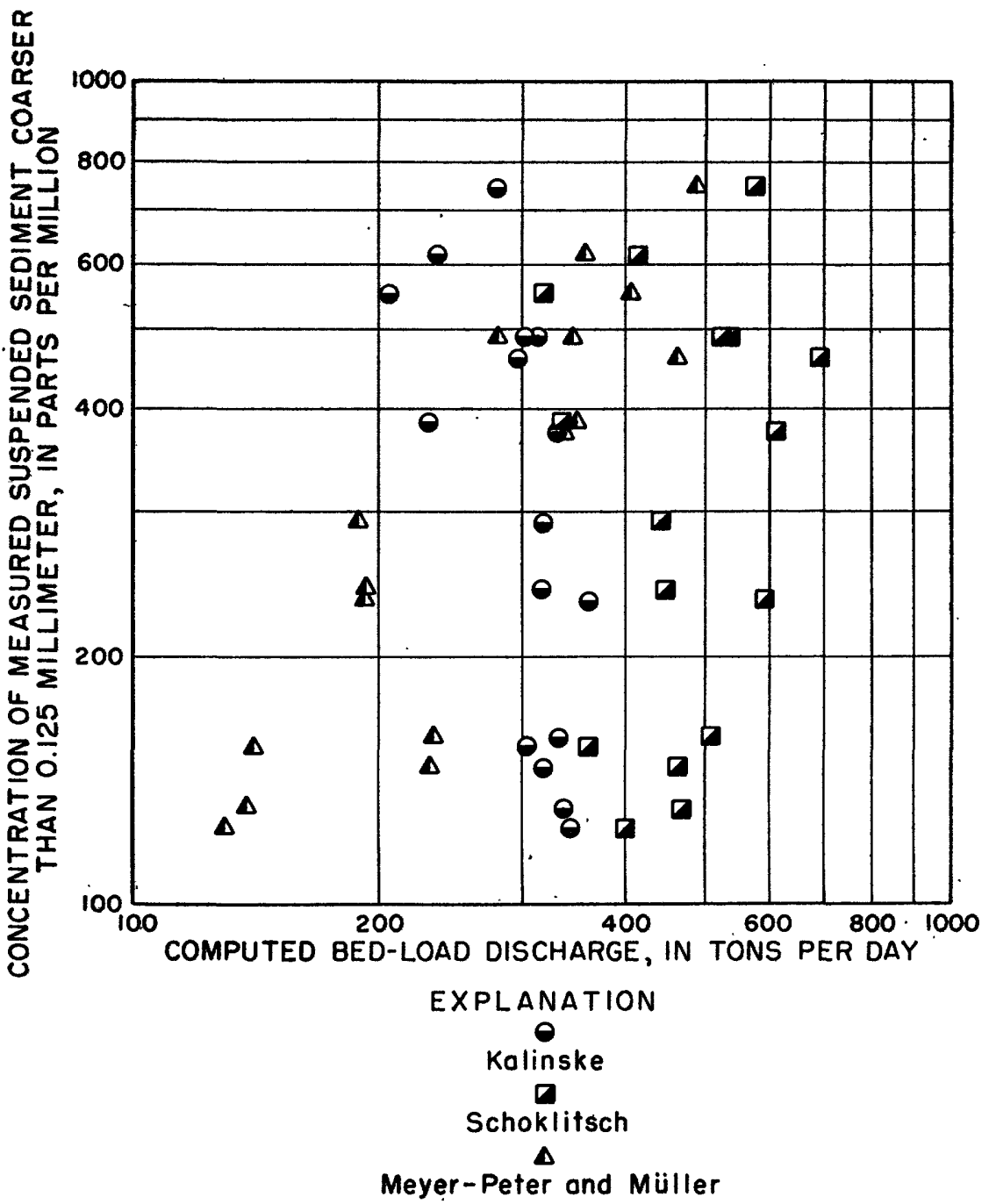

Froune 30.-Computed bed-load discharge plotted against concentration of measured suspended sediment coarser than $0.125 \mathrm{~mm}$. 


\section{SCHOKLTTSCH FQUATION}

Samuel Shulits (1935, p. 644-646, 687) has published a discussion of the Schoklitsch bed-load equation. The basis for this equation is that bed material will begin to move at some critical flow and that the bed-load discharge is proportional to the work done by the part of the tractive force in excess of that needed to overcome the resistance along the wetted perimeter. If $A_{o}$ is the cross-sectional area of a flow that is just sufficient to move the bed material and $A_{f}$ is the cross-sectional area of flow, with no change in width, the effective part of the tractive force in moving bed material is $\gamma S\left(A_{f}-A_{o}\right)$. Also, if the velocity of the tractive force is proportional to the mean velocity of flow, $\bar{u}$, then the work done by the effective part of the tractive force is $c_{1} \bar{u} \gamma \mathrm{S}\left(A_{f}-A_{o}\right)$ or $c_{1} \gamma S\left(Q_{w}-Q_{o}\right)$. Hence, if the bedload discharge is proportional to the work, $G_{b}$ is equal to $C \gamma S\left(Q_{w}-Q_{o}\right)$. The constant, $C$, is a function of the slope and the particle size. The final equation for the unigranular material is-

in which-

$$
g_{b}=43.2\left[\frac{86.7}{\sqrt{D}} S^{3 / 2}\left(Q_{w}-w q_{0}\right)\right]
$$

$D$ is the mean particle size, in inches, and in this report it is used as the geometric mean.

$Q_{w}$ is the instantaneous water discharge, in cubic feet per second. $q_{o}$ is the water discharge per foot of width just sufficient to move

bed material. It is the critical water discharge per foot of width and equals $0.00532 \mathrm{D} / \mathrm{S}^{4 / 3}$.

For sand mixtures, the bed-load discharge, in tons per day, of each size range, is computed according to the above equation, and the bed-load discharge for all size ranges is a weighted summation of each individual range. The weighting factor for the load in each range is the fraction of the total bed mixture which that range represents.

Seventeen computations of the bed-load discharge at section $\mathbf{E}$ were made with the Schoklitsch equation for sand mixtures. The results of these computations are given in table 9. Computed discharges tend to increase slightly as both the total sediment discharge and the unmeasured sediment discharge increase; however, five of the computations gave bed-load discharges greater than comparable unmeasured sediment discharges. In general, computed discharges were higher than those computed with the other bed-load formulas. The different hydraulic conditions produced a fairly wide range of computed discharges, but the discharges did not vary consistently with any of the hydraulic parameters that were examined. 
Figure 30 shows that computed discharges tend to increase as the concentrations of measured suspended sediment coarser than 0.125 millimeter increase. These computations seem to indicate that computed discharges include the bed-load discharge and a part of the suspended-sediment discharge.

\section{MEYER-PETER AND MÜLLER FQUATION}

Meyer-Peter and Müller (1948) have presented an equation for computing the bed-load discharge in natural streams. The equation is based on tests that were made in laboratory flumes of various scales and in the region of fully developed turbulence. The shearing stress was shown to be an important factor in bed-load transport by these tests, which were made throughout wide ranges of slope, particle size, water depth, water discharge, and specific gravity of sediment. For wide channels, the equation can be written-

in which-

$$
\gamma\left(\frac{k_{t}}{k_{\tau}}\right)^{3 / 2} d S=\underline{E} \underline{\gamma}_{g} D_{m}+\underline{F}\left(\frac{\gamma}{g}\right)^{1 / 3} \underline{g}_{s}^{2 / 3}
$$

$\gamma$ is the specific weight of water and equals 1 metric ton per cubic meter (1 gram per cubic centimeter). This parameter is called specific gravity with the units indicated by MeyerPeter and Müller and is designated $\gamma_{w}$.

$k_{r}$ is the coefficient of particle friction with a smooth bed and is equal to $26 / D_{90}^{1 / 6}$.

$k_{t}$ is the coefficient of roughness, given by Meyer-Peter and Müller as $k_{s}$ and is equal to $\bar{u} / d^{2 / 3} S^{1 / 2}$.

$d$ is the mean depth of water, in meters, and is given by MeyerPeter and Müller as $h$.

$E$ is a constant that equals 0.047 and is given by Meyer-Peter and Müller as $\mathbf{A}^{\prime \prime}$.

$\gamma_{g}$ is the specific weight of the sediment under water and equals 1.65 metric tons per cubic meter (1.65 grams per cubic centimeter) for this report. This parometer is called the specific gravity under water by Meyer-Peter and Müller with the units indicated above and is designated as $\gamma_{s}$.

$D_{m}$ is the "effective diameter" of the bed-material mixture, in meters, and is equal to $\Sigma D i_{b}$.

$F$ is a constant that equals 0.25 and is given by Meyer-Peter and Müller as $B^{\prime \prime}$.

$g$ is the gravity constant and equals 9.815 meters per second per second.

$g_{s}$ is the bed-load discharge per meter of width, in metric tons per meter per second ( $1 \times 10^{6}$ grams per meter per second), as measured under water. 
where-

$D_{90}$ is the particle size, in meters, at which 90 percent of the bed material by weight is finer.

$\bar{u}$ is the mean velocity of flow, in meters per second.

$D$ is the geometric mean size, in meters, of a size fraction.

Seventeen bed-load discharges for section $\mathbf{E}$ that were computed with the Meyer-Peter and Müller equation are given in table 9. Computed discharges compare reasonably with total sediment discharges and unmeasured sediment discharges. The different hydraulic conditions produced a relatively wide range of bed-load discharges, and the discharges varied progressively with progressive changes in several hydraulic parameters that were examined-particularly mean velocity. Figure 30 shows that the computed bed-load discharges increase as the concentrations of measured suspended sediment coarser than 0.125 millimeter increase. On the basis of these computations, bed-load discharges computed with the Meyer-Peter and Müller equation seem to be accurate measures of the actual bed-load discharge.

\section{SIZE DISTRIBUTION OF BED MATERIAL}

In alluvial streams, such as the Middle Loup River, the size distribution of bed material varies both laterally and vertically. The variations have been studied from regular and special samples from section E. Piston-type samplers that obtain cores about 2 inches in diameter and about 6 inches in length were used for all the sampling.

Because the size distribution of bed material varies laterally across a section (fig. 31), the size distributions of sample composites from only a few points have less possibility of being representative of the whole cross section than the size distributions of composites from many points. Data on April 26 and March 30, 1951, show the results when different numbers of samples are composited (table 4, section E). For April 26 the composite of 3 samples has a distinctly coarser distribution than the composite of 29 samples, and for March 30 the composite of 3 samples collected at centers of maximum discharge sections has a coarser distribution than the composite of 7 samples. On the basis of data from section $\mathrm{E}$, at least five samples, but preferably more, should be collected for a composite to define adequately the bed-material size distribution at a cross section.

An example of the vertical variation in the size distribution of bed material for one time and station is given in figure 32. Size analyses of the top 0.5 inch of 6 -inch cores (table 4, section $E$ ) and size analyses from station 77 on May 6, 1952, (fig. 32) indicate that, in general, the material near the surface of the bed is somewhat finer than that for an entire 6-inch core. However, at any station 


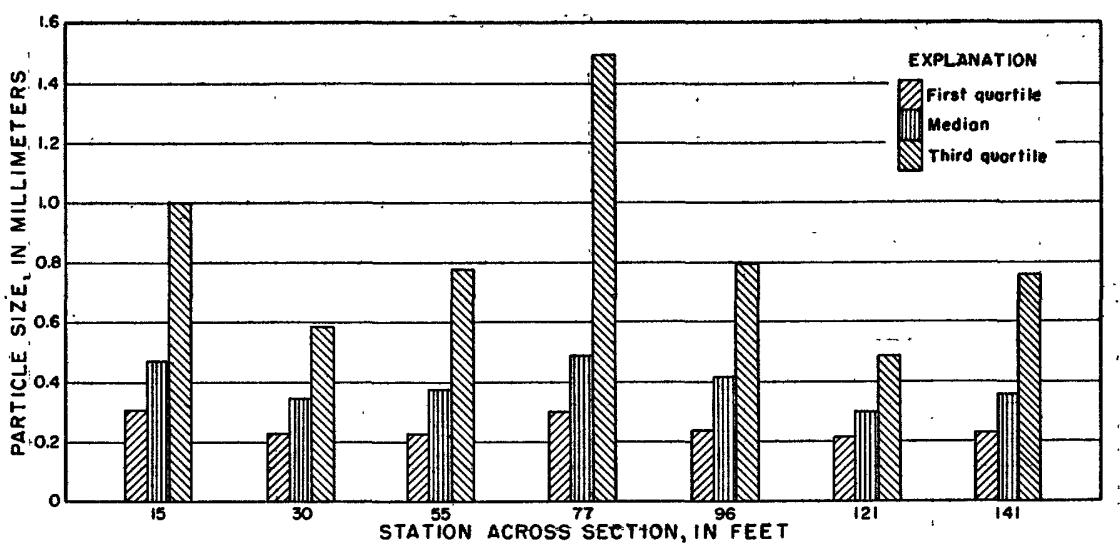

Figure 31.-Lateral variation of the size distribution of bed material, section E, MaJ 6, 1952.

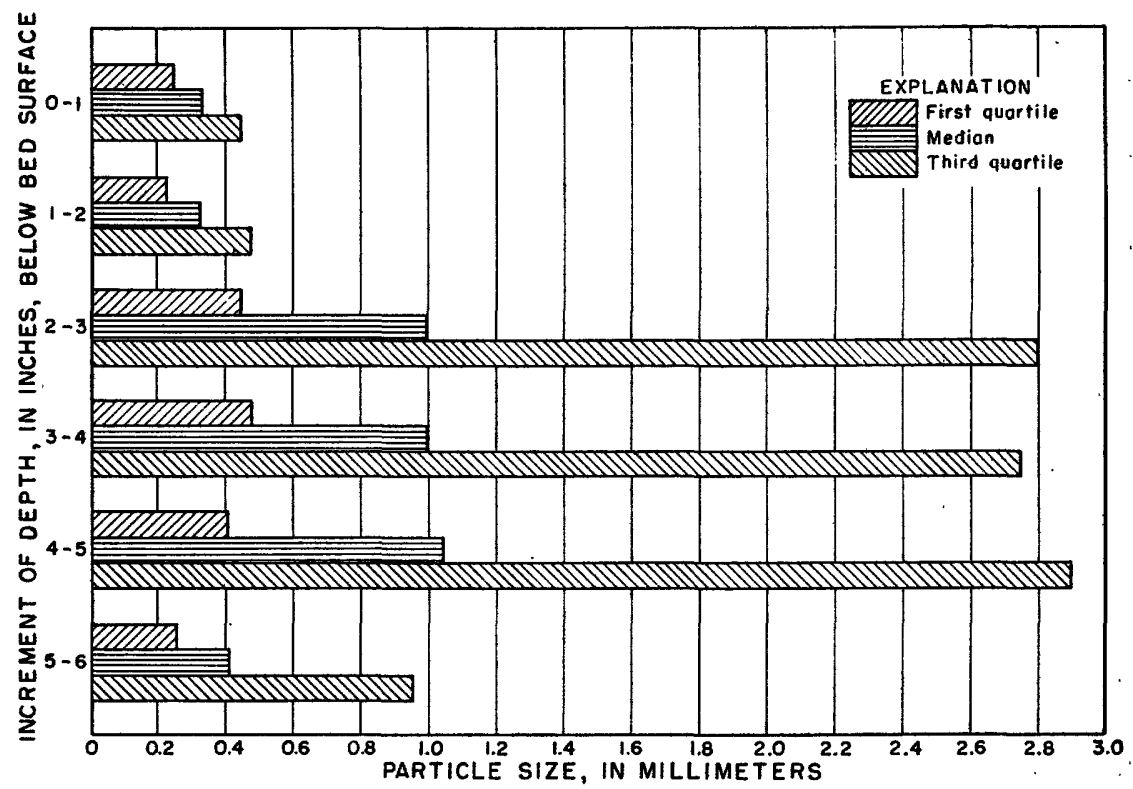

Figure 32.-Vertical variation of the size distribution of bed material, section E, station 77, May 6, 1952.

the vertical size distribution is continually changing as dunes move through the section.

The median particle size of bed material at sections $\mathrm{A}, \mathrm{C}_{2}$, and $\mathrm{E}$, determined from 6 -inch core samples, seems to have no direct relation with either the water discharge or the water temperature (fig. 33). First- and third-quartile particle sizes at section $A$ also showed no such relation.

On streams such as the Middle Loup River, where sediment is relatively coarse and unlimited in supply and where the size dis- 

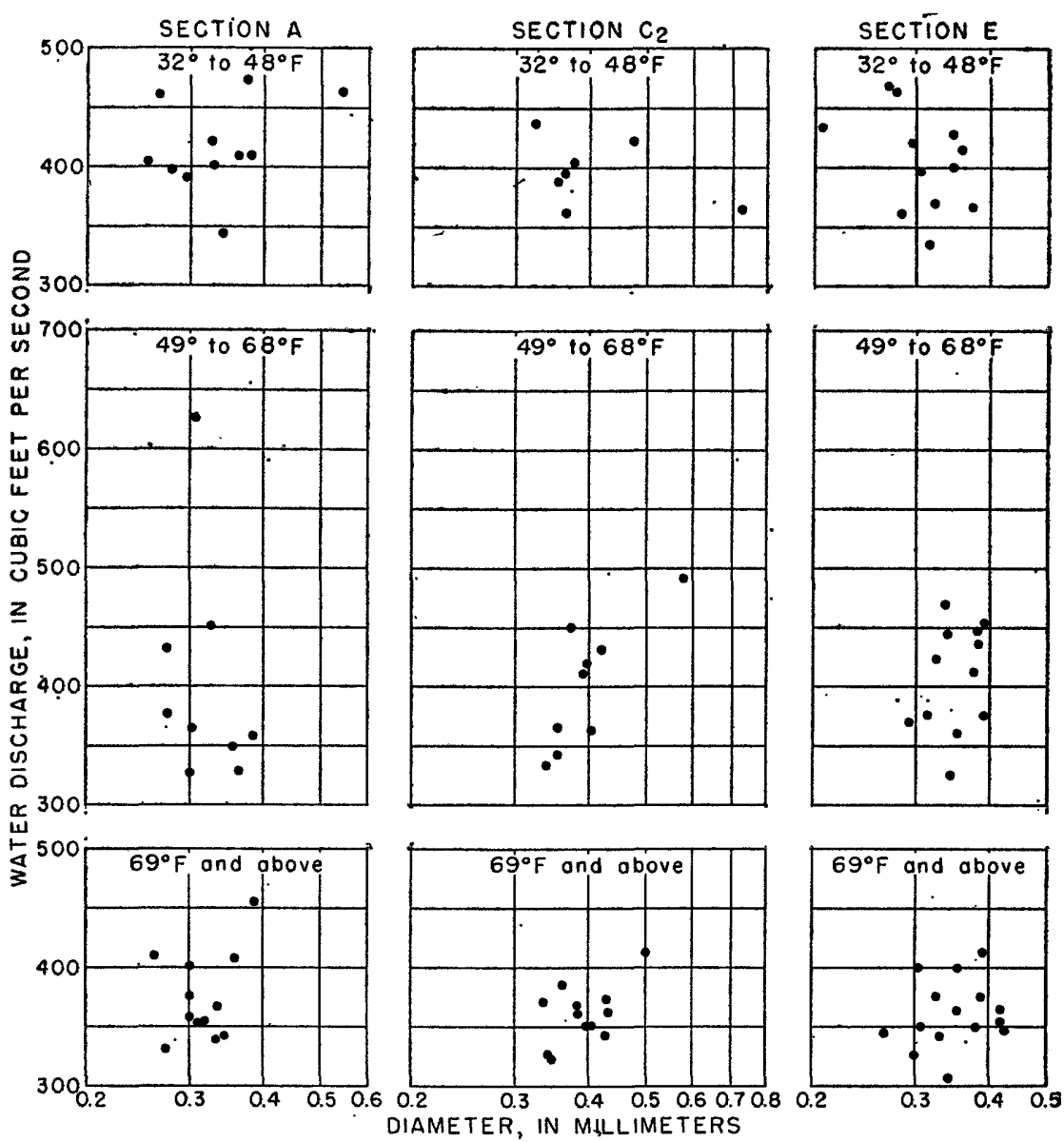

FiguRe 33.--Variation of median particle size of bed material with water temperature and discharge tribution is evidently unrelated to water discharge and water temperature, the most representative size distribution can probably be determined from an average of all available samples.

\section{VARIATIONS IN $z_{1}$}

The equation for the vertical distribution of suspended sediment has been recapitulated by Einstein (1950, equation 29) as-

in which-

$$
\frac{c_{y}}{c_{a}}=\left(\frac{d-y}{y} \frac{a}{d-a}\right)^{2}
$$

$z$ equals $V_{s} / k u_{*}$. 
where-

$k$ is the Von Karman coefficient for turbulent exchange. Anderson (1942), Vanoni (1941), and others have found that the exponential form of this equation is satisfactory but that $z$ should be replaced by $z_{1}$, the exponent that fits the measured data. Vanoni (1941) has proposed that differences in $z$ and $z_{1}$ for fine particle sizes result from the derivation of $z$ when the sediment transfer coefficient and the momentum transfer coefficient are assumed to be equal. Einstein and Ning Chien (1954) developed formulas for $z_{1}$ on the assumptions that mixing lengths are of variable distance in all directions and that the concentration changes along the mixing length. Colby and Hembree (1955) demonstrated that $z_{1}$ varies, on the average, with about the 0.7 power of the fall velocity when fall velocities are based on Rubey's equation.

For Nebraska sandhill streams, a $z_{1}$ less than about 0.7 is generally larger than an associated $z$ that is computed with a $V_{s}$ from figure 34, a $k$ from velocities determined from the point-integrated samples used to define the $z_{1}$, and a $u_{*}$ from $\sqrt{d S g}$. (See fig. 35.) However, for flumes and relatively deep streams, other investigators have found that a $z_{1}$ less than 1.0 is about equal to an associated $z$. The difference in the $z_{1}$ versus $z$ relationship is because values of $k$ for sandhill streams are larger than those for flumes and relatively deep streams.

Flume experiments and measurements in relatively deep streams indicate that $k$ is generally les $s$ than 0.4 and that $k$ decreases as sediment concentration increases. However, for the Niobrara River, Colby and Hembree (1955) found that $k$ varies markedly; investigations for other Nebraska sandhill streams show that $k$ varies from about 0.4 to 4.00 . This range is for $k$ 's that are averages of the $k$ 's at sampled verticals in a cross section; each $k$ at a vertical was determined from the velocity profile that was defined by point-integrated samples at 3 or 4 points in the vertical, sampling verticals were not consistent with respect to their position on the dune, and the relative roughness of the bed in the vicinity of the sampling verticals varied widely and was often very great. Because the theory of velocity distribution probably is invalid where the relative roughness is extremely great, the significance of a $k$ determined from these samples is unknown.

For sandhill streams that have a range of $k$ from 0.4 to $4.00, z_{1}$ varies inversely with about the 0.6 power of $k$. (See fig. 36.) Throughout this range of $k$, the relation seems to be continuous.

For these same streams, $z_{1}$ can be expressed as a power of $z$. Figure 37, which includes some of the data used by Colby and Hembree (1955), shows that $z_{1}$ varies with about the 0.6 power of $z$. The fall velocities for this graph are based on data from figure 34 . If fall 


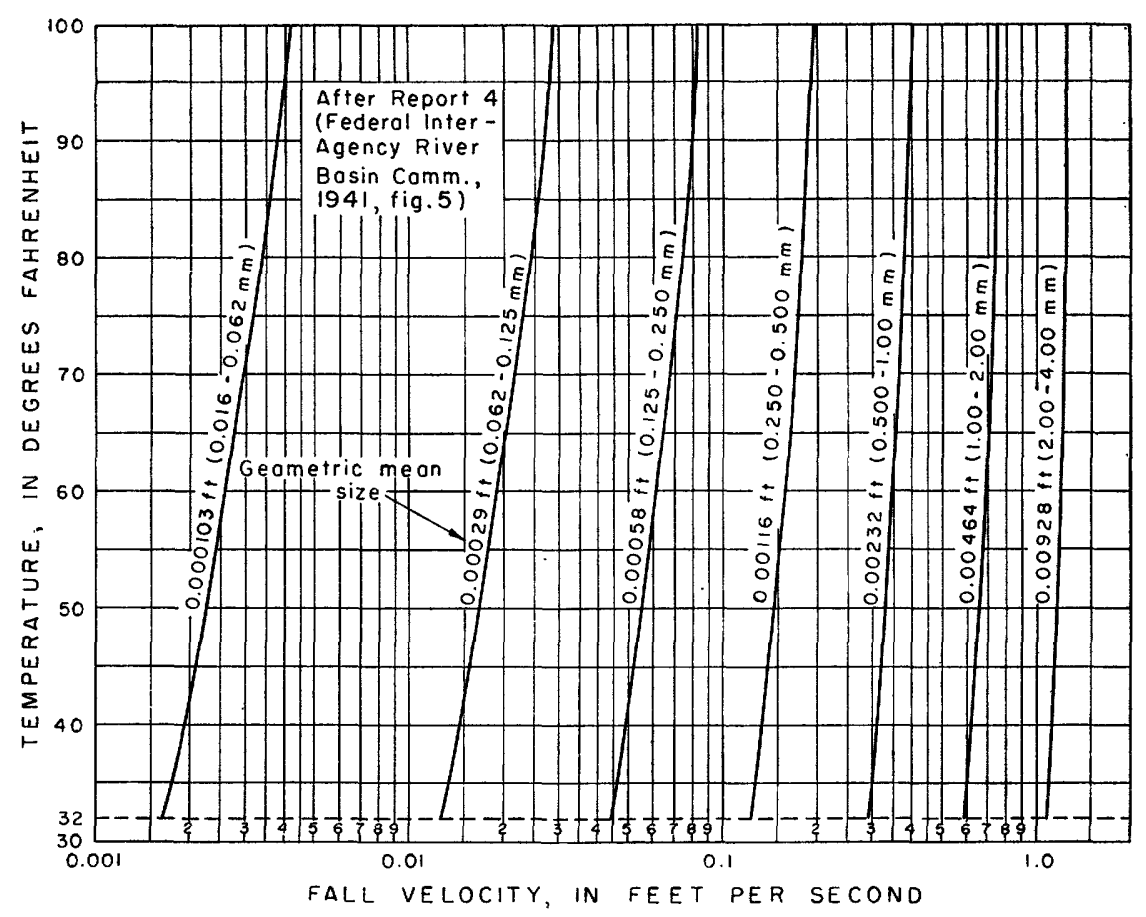

FIGURE 34.-Fall velocity of quartz spheres in water.

velocities (fig. 38) are based on Rubey's equation (1933), a graph similar to figure 37 can be developed by plotting $z_{1}$ against $z^{0.7}$. Data obtained by Anderson (1942) and data from the Mississippi River at St. Louis generally plot within the limits of the scatter in figure 37; however, these data have been omitted in order to avoid any implication that the relationships have any known theoretical basis or will be representative of all streams.

\section{CONCLUSIONS}

For the normal ranges of water discharge of the Middle Loup River at Dunning, Nebr., about 75-80 percent of the measured suspended sediment at the 6 selected river sections is coarser than 0.062 millimeter, and about 40 percent is in the 0.125 - to 0.25 -millimeter size fraction. Also, the median diameter of bed material is in the $0.25-$ to 0.50 -millimeter range.

Vertical distributions indicate slightly more turbulence at section $\mathrm{C}$ than at the selected river sections. Also, about 88 percent of the measured suspended sediment entering the flume at section $C$ is coarser than 0.062 millimeter, and about half of the total sand is in the 0.125 - to 0.25 -millimeter size fraction, although the median bed- 


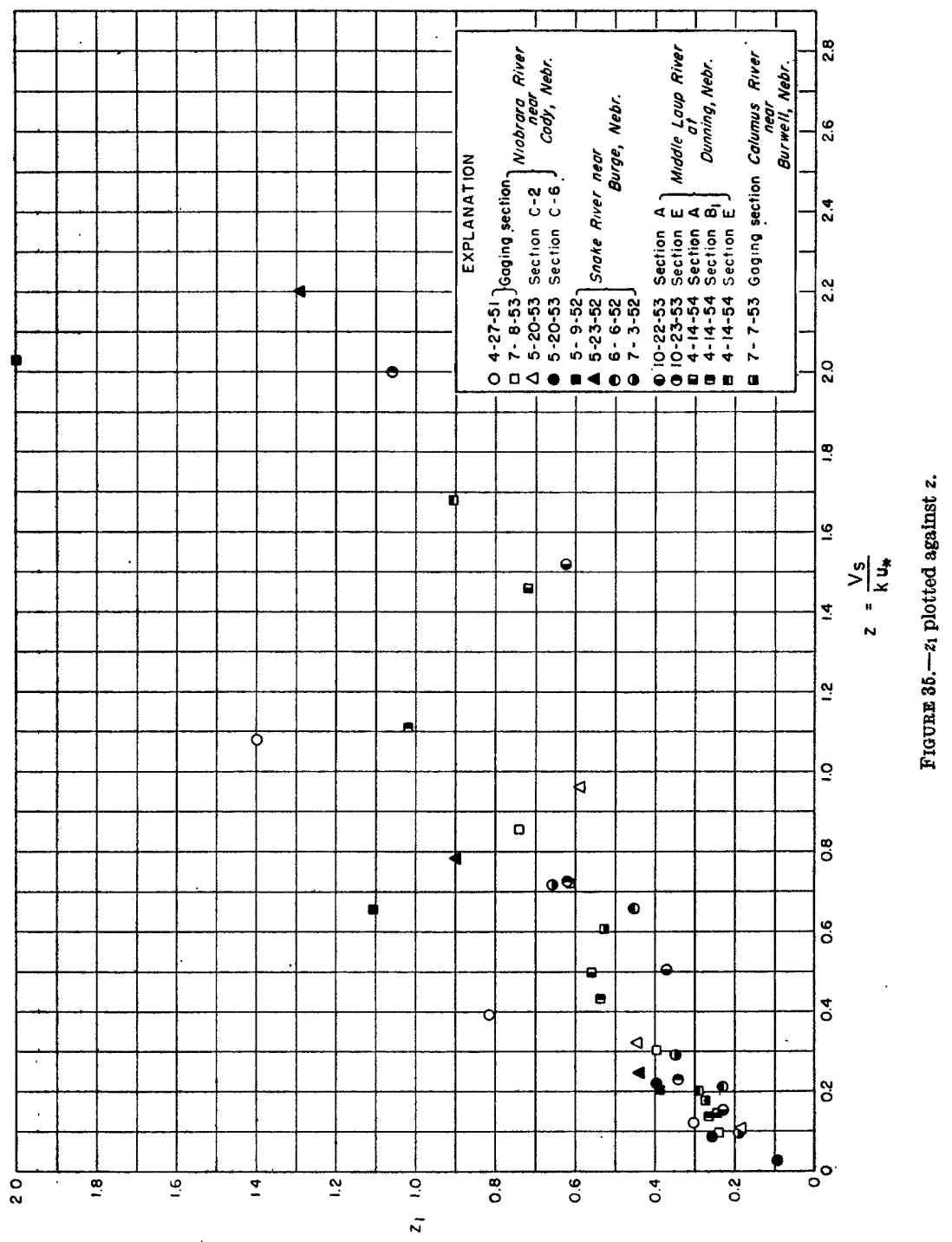




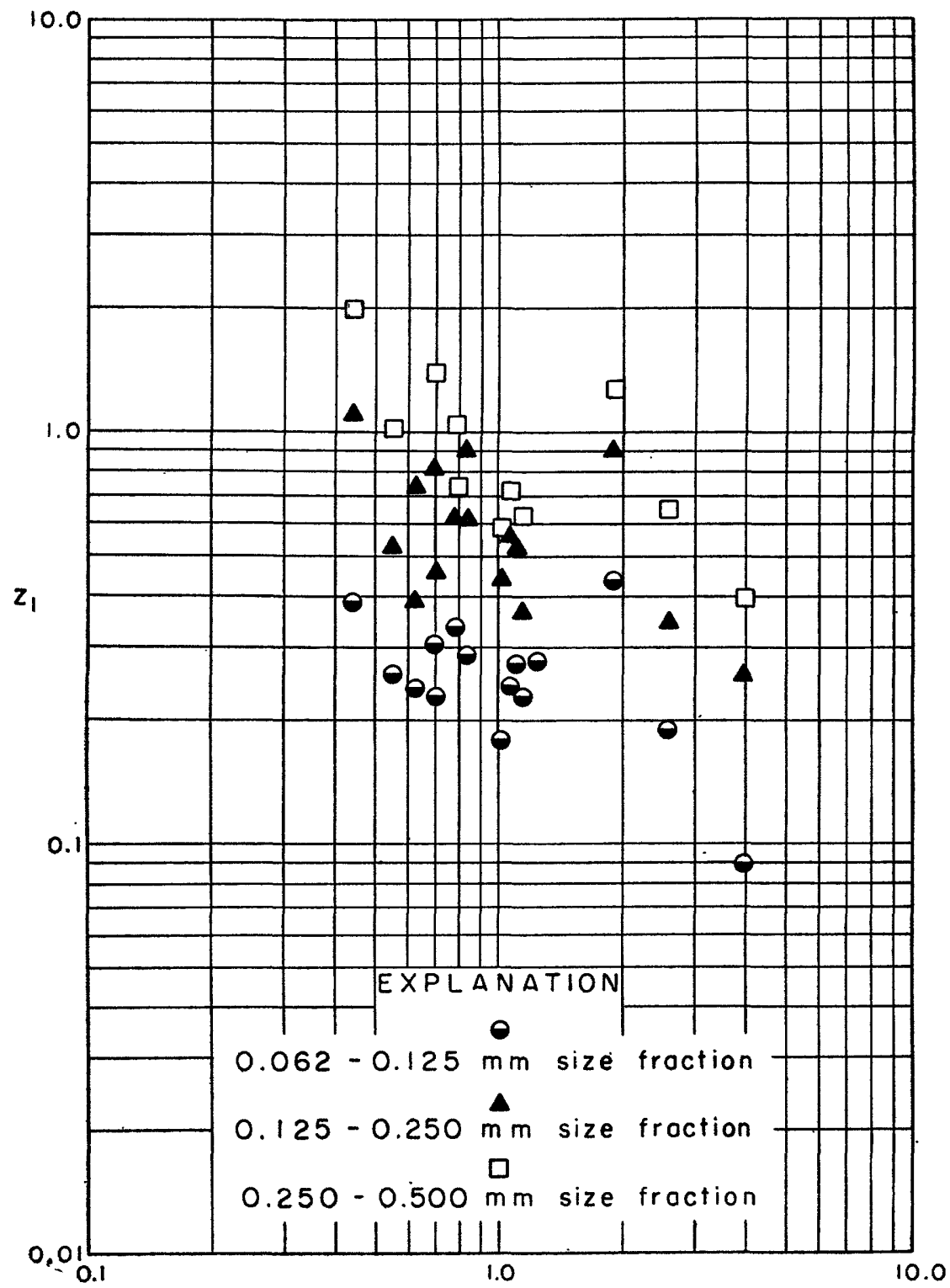

$k$, VON KARMAN COEFFICIENT FOR TURBULENT EXCHANGE 


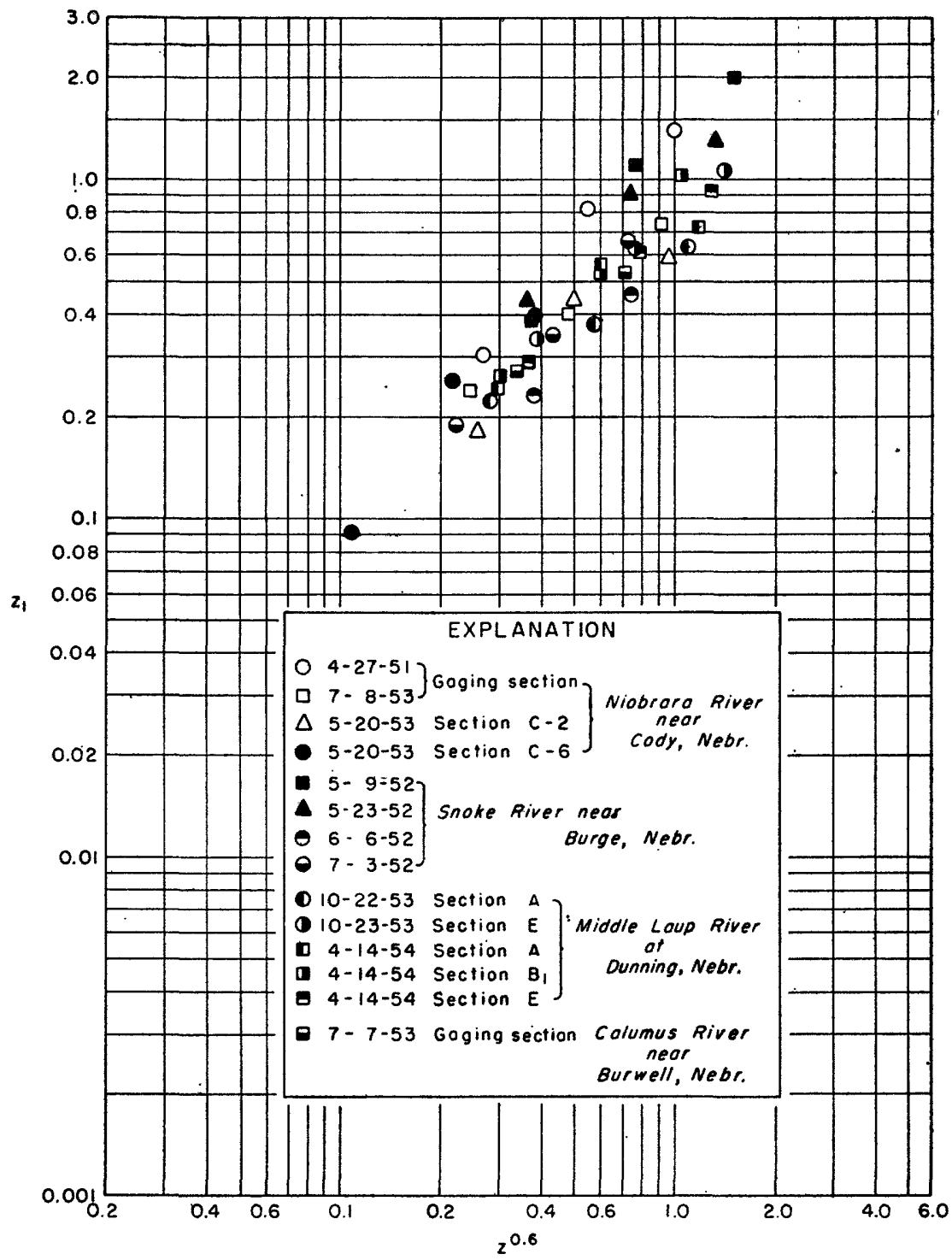

Figurx 37. $-z_{1}$ expressed as a power of $z$.

material size just upstream from section $\mathrm{C}$ is about the same as that at the river sections.

About 90 percent of the measured total sediment discharge at section $\mathrm{D}$ is coarser than 0.062 millimeter, and about 35 percent is in the 0.125 - to 0.25 -millimeter size fraction.

The total sediment discharge varies about as the cube of the water discharge; however, the relationship is not well defined. 


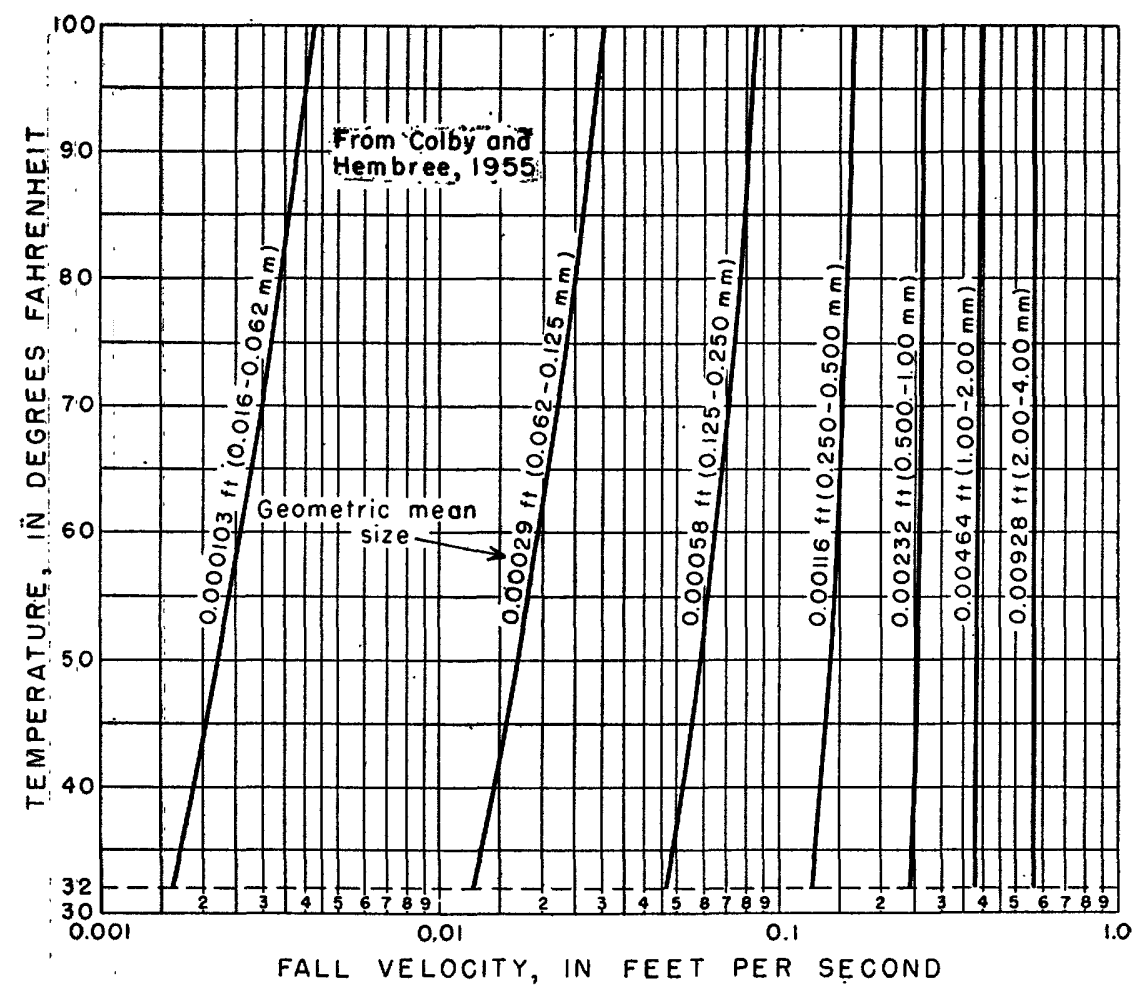

Figure 38.-Variation of fall velocity with temperature from the Rubey equation.

Forty-four determinations of the ratio of daily sample concentrations to cross-section concentrations at section $D$ averaged 1.03 and ranged from 0.72 to 1.61 . Fluctuations of this ratio cannot be explained by any of the common flow parameters.

Computations by the Einstein procedure indicate that accurate sediment discharges can be obtained only if the computed cross section is representative of the reach that is being studied. For the Dunning reach, when the computed cross section was narrower and deeper than a representative cross section, computed loads were high; and when the computed cross section was wider and shallower than a representative cross section, computed loads were low. However, when section $\mathrm{E}$, which is probably nearly representative of the Dunning reach, was used as the cross section, computed total loads (computed discharge of sediment coarser than 0.125 millimeter plus the discharge of measured sediment finer than 0.125 millimeter) averaged 115 percent and ranged from 31 to 240 percent (standard deviation, 94 percent) of measured total loads. The accuracy of the Einstein procedure cannot be evaluated because only a limited number of cross sections were measured for this investigation and the computations did not include as many sections as recommended by 
Einstein to define adequately the representative cross section. However, of the various combinations of sections that were available, the four-section combination of section $A, B$ (or $B_{1}$ or 25 feet upstream from $B), C_{2}$, and $E$ gave the best average results. Computed total loads averaged 81 percent and ranged from 26 to 150 percent (standard deviation, 49 percent) of the measured total loads. Computed loads larger than 0.125 millimeter were less accurate than computed total loads. Also, in most computations, the largest part of the total load was in the 0.25 - to 0.50 -millimeter size fraction; however, the largest part of the measured total load was usually in the 0.125 to 0.25 -millimeter size fraction.

Computations of total sediment discharge by the modified Einstein procedure averaged 112 percent and ranged from 64 to 166 percent (standard deviation, 22 percent) of measured total loads. Also, computed loads by size ranges agreed fairly closely with comparable measured loads. On the basis of these computations, the procedure appears to be satisfactory for use on streams similar to the Middle Loup River. Although the procedure is satisfactory for any section, best results are obtained for sections where the lateral distributions of stream depth, stream velocity, and measured suspended-sediment concentrations are relatively uniform.

Computations of sediment discharge for section $\mathrm{E}$ by the Straub equation averaged about twice the measured total sediment loads. The equation seems to be more suitable for deep streams or shallow streams that have flat gradients than for streams that have hydraulic characteristics like those of the Middle Loup River.

Computations for section $\mathrm{E}$ by the Kalinske equation indicate that the equation gives bed-load discharges in the proper order of magnitude. However, computed discharges are relatively constant for the range of hydraulic conditions that exist at the Middle Loup River at Dunning; low computed discharges are associated with high total sediment discharges, high unmeasured sediment discharges, and high concentrations of measured suspended sediment coarser than 0.125 millimeter; and high computed discharges are associated with low total sediment discharges, low unmeasured sediment discharges, and low concentrations of measured suspended sediment coarser than 0.125 millimeter.

Computations for section $\mathrm{E}$ by the Schoklitsch equation gave bedload discharges that seem somewhat high; about one-third of the computed loads were slightly higher than comparable unmeasured loads. In general, high computed discharges were associated with high total sediment discharges, high unmeasured sediment discharges, and high concentrations of measured suspended sediment coarser than 0.125 millimeter; low computed discharges were associated with low total sediment discharges, low unmeasured sediment discharges, and low $468443-59-7$ 
concentrations of measured suspended sediment coarser than 0.125 millimeter. However, the trend was not progressively consistent.

Computations for section $\mathrm{E}$ by the Meyer-Peter and Müller equation gave bed-load discharges that seem to be accurate measures of the the actual bed-load discharges. Computed loads varied progressively with changes in several hydraulic parameters, compared reasonably with total and unmeasured sediment discharges, and increased fairly consistently as the concentrations of measured suspended sediment coarser than 0.125 millimeter increased.

Size analyses indicated that the bed material varies both laterally and vertically. On the basis of samples collected at section $\mathrm{E}$, at least five samples, but preferably more, seem to be necessary for an adequate determination of the bed-material size distribution at a cross section. The size distribution for the top 1 inch or so of the bed is generally finer than that for the top 6 inches. For 6-inch cores, the median and the first- and third-quartile particle sizes seem to have no direct relation with either water discharge or water temperature. As a result, on streams similar to the Middle Loup River the most representative bed-material size distribution from 6-inch cores can probably be determined from an average of all available samples.

For Nebraska sandhill streams, a $z_{1}$, from point-integrated samples, that is less than about 0.7 is generally larger than a comparable $z$ from $V_{\mathrm{s}} / k u_{*}$, where the $V_{\mathrm{s}}$ is based on the fall velocity of quartz spheres in water. Throughout a range for the Von Karman coefficient, $k$, of $0.4-4.00, z_{1}$ varies inversely with about the 0.6 power of $k$. In addition, $z_{1}$ can be expressed roughly as a power of $z$; the power depends on which system of fall velocities is used.

\section{LITERATURE CITED}

Anderson, A. G., 1942, Distribution of suspended sediment in a natural stream: Am. Geophys. Union Trans., 23d Ann. Mtg., pt. 2, p. 678-683.

Benedict, P. C., Albertson, M. L., and Matejka, D. Q., 1955, Total sediment load measured in turbulence flume: Am. Soc. Civil Engineers Trans., v. 120, p. 457-484.

Colby, B. R., and Hembree, C. H., 1955, Computations of total sediment discharge, Niobrara River near Cody, Nebr.: U. S. Geol. Survey Water-Supply Paper 1357, $187 \mathrm{p}$.

Einstein, H. A., 1950, The bed-load function for sediment transportation in open channel flows: U. S. Dept. Agr. Tech. Bull. 1026, 70 p. [1951].

Einstein, H. A., and Chien, Ning, 1954, Second approximation to the solution of the suspended load theory: California Univ. Inst. Eng. Research, Missouri River Div. sediment ser. 3, $30 \mathrm{p}$.

Federal Inter-Agency River Basin Comm., 1941, Methods of analyzing sediment samples, in A study of methods used in measurement and analysis of sediment loads in streams: rept. 4, p. 41.

Kalinske, A. A., 1947, Movement of sediment as bed load in rivers: Am. Geophys. Union Trans., v. 28, p. 615-620. 
Keulegan, G. H., 1938, Laws of turbulent flow in open channels: U. S. Natl. Bur. Standards, Jour. Research, v. 21, no. 6, p. 707-741.

Meyer-Peter, E., and Müller, R., 1948, Formulas for bed-load transport: Internat. Assoc. for Hydraulic Structures Research, 2d Mtg., Stockholm, Sweden, p. 39-64.

Rubey, W. W., 1933, Settling velocities of gravel, sand, and silt particles: Am. Jour. Sci., 5th ser., v. 25, no. 148, p. 332.

Shulits, Samuel, 1935, The Schoklitsch bed-load formula: Engr., v. 139, p. 644 $646,687$.

U. S. Congress, 1935, Missouri River: 73d Cong., 2d sess., H. Doc. 238, p. 11241138 .

U. S. Geological Survey, 1953, Quality of surface waters of the United States, 1948: U. S. Geol. Survey Water-Supply Paper 1132.

1954, Quality of surface waters of the United States, 1949: U. S. Geol. Survey Water-Supply Paper 1162.

1954, Surface water supply of the United States, 1951, Pt. 6B. Missouri River basin below Sioux City, Iowa: U. S. Geol. Survey Water-Supply Paper $1210,452 \mathrm{p}$.

1955, Quality of surface waters of the United States, 1950: U. S. Geol. Survey Water-Supply Paper 1187.

Vanoni, V. A., 1941, Some experiments on the transportation of suspended load: Am. Geophys. Union Trans., 22d Ann. Mtg., pt. 3, p. 608-620.

\section{SYMBOLS}

Single prime mark on $A, J$, or $Q$ designates association with the sampling depth

Page

Double prime mark on $A, J, I$, or $Q$ designates association with the total depth through which suspended sediment is discharged

Triple prime mark on $Q$ designates association with the total sediment discharge

Distance above the stream bed.

Distance of the lower limit of integration above the stream bed divided by $d$.

Cross-sectional area of flow.

Cross-sectional area when flow is just sufficient to move bed material

A proportionality constant

Concentration of sediment particles of a size fraction at distance, $a$, above the stream bed.

Concentration of sediment particles of a size fraction at distance, $y$, above the stream bed.

A proportionality constant.

A constant

$\begin{array}{ll}\text { Conc } & \text { Measured suspended-sediment concentration } \\ \text { Conc } & \text { Mean concentration of the suspended-sediment discharge in the }\end{array}$ unsampled zone

Distance from the bottom of the sampled zone to the stream bed. 
$D$

$D_{35}$

$D_{65}$

$D_{90}$

$D_{m}$

$\underline{E}$

$\underline{F}$

$g$

$g_{b}$

$\frac{g_{\mathrm{s}}}{G}$

$G$

$G_{b}$

$i_{b}$

$i_{B} q_{B}$

$i_{B} Q_{B}$

$I_{1}$

$I_{2}$

$J_{1}$

$J_{2}$

$k$

$k$

$k_{s}$

k,

K

$K_{1}$

$K_{0}$

$K_{\text {oo }}$

m

$p$

$p_{i}$

$P$

qo

Q

$Q$.

$Q_{s M}$

$Q_{t s}$

$Q_{t s}^{\prime}$

$Q_{u M}$

$Q_{\text {usM }}$

$Q_{w}$

$r$

R

$(R S)_{m}$

$S$ $d_{s} \quad$ Average depth at the sampling verticals

Page

Particle size at which 35 percent of the bed material by weight is finer

Particle size at which 65 percent of the bed material by weight is finer.

Particle size at which 90 percent of the bed material by weight is finer.

Effective diameter of the bed-material mixture

A constant.

A constant.

The gravity constant.

Bed-load discharge of a size fraction

Bed-load discharge per meter of width as measured under water

Sediment discharge from the Straub equation.

Bed-load discharge

Fraction by weight of bed material in a size range.......

Sediment discharge per unit width through the bed layer of particles of a size fraction.

Sediment discharge through the bed layer of particles of a size fraction.

A mathematical abbreviation that contains $J_{1}$

Relative intensity of turbulence.

Ratio of the mean concentration in the unsampled zone to that in the sampled zone

Quantity obtained by solving equation a for $(R S)$

be equal to the slope of the water surface 
Mean speed of movement of the particles of a size range......-

Fall velocity of the geometric mean size of the range requiring a

$z_{2}$

Width of the stream channel

Dimensionless transition parameter. 47

Characteristic grain size of the bed mixture

Distance above the stream bed...... 48

Pressure correction in the transition from smooth to rough flow $\quad 51$

Theoretical exponent of the equation that describes the vertical distribution of suspended sediment of a size range.

Exponent for the actual distribution of suspended sediment of a size range determined from a logarithmic plot of concentration in a size range versus $(d-y) / y$.

Exponent for a size range that will determine values of $I$ and $J$ to satisfy equation $f$ or an exponent determined by proportion from an exponent determined in the above manner...$z_{2}$ for the reference range . . Unknown and required $z_{2}$ for a size range

Exponent for a size range that will determine values of $I$ and $J$ to satisfy equation $\mathrm{h}$ or an exponent determined by proportion from an exponent determined in the above manner....

Exponent determined from an empirical equation..........

Exponent computed from $V_{s} / 0.4 u_{m}$

Represents either $z_{1}, z_{3}$, or $z_{4}$

$\log _{10}(10.6)$

$\log _{10}\left(10.6 X x / k_{8}\right)$

Specific weight of water

Specific weight of sediment particles.

Specific weight of sediment particles under water.

Thickness of the laminar sublayer. Transportation characteristic and corresponds to Straub's $\Psi_{-}$.

Kinematic viscosity

Hiding factor of grains in a mixture

Mass density of sediment

Critical tractive force

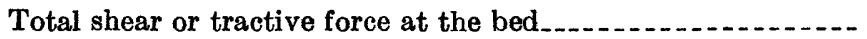

Intensity of bed-load transport from Einstein . .

Intensity of bed-load transport from the modified procedure.--

Function for correlating the effect of flow with the intensity of bed-load transport.

Flow intensity from the modified procedure..... 


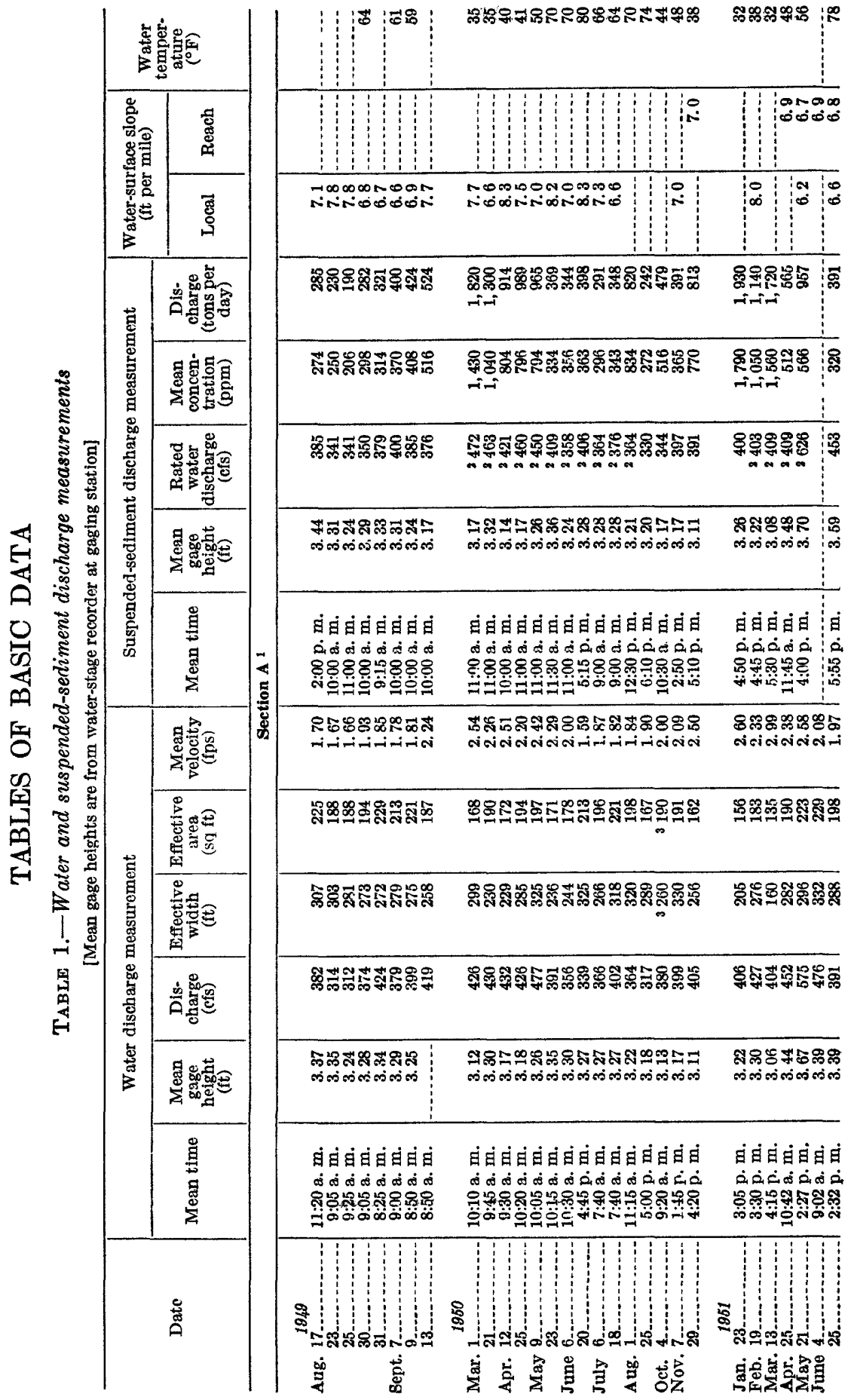


TABLES OF BASIC DATA

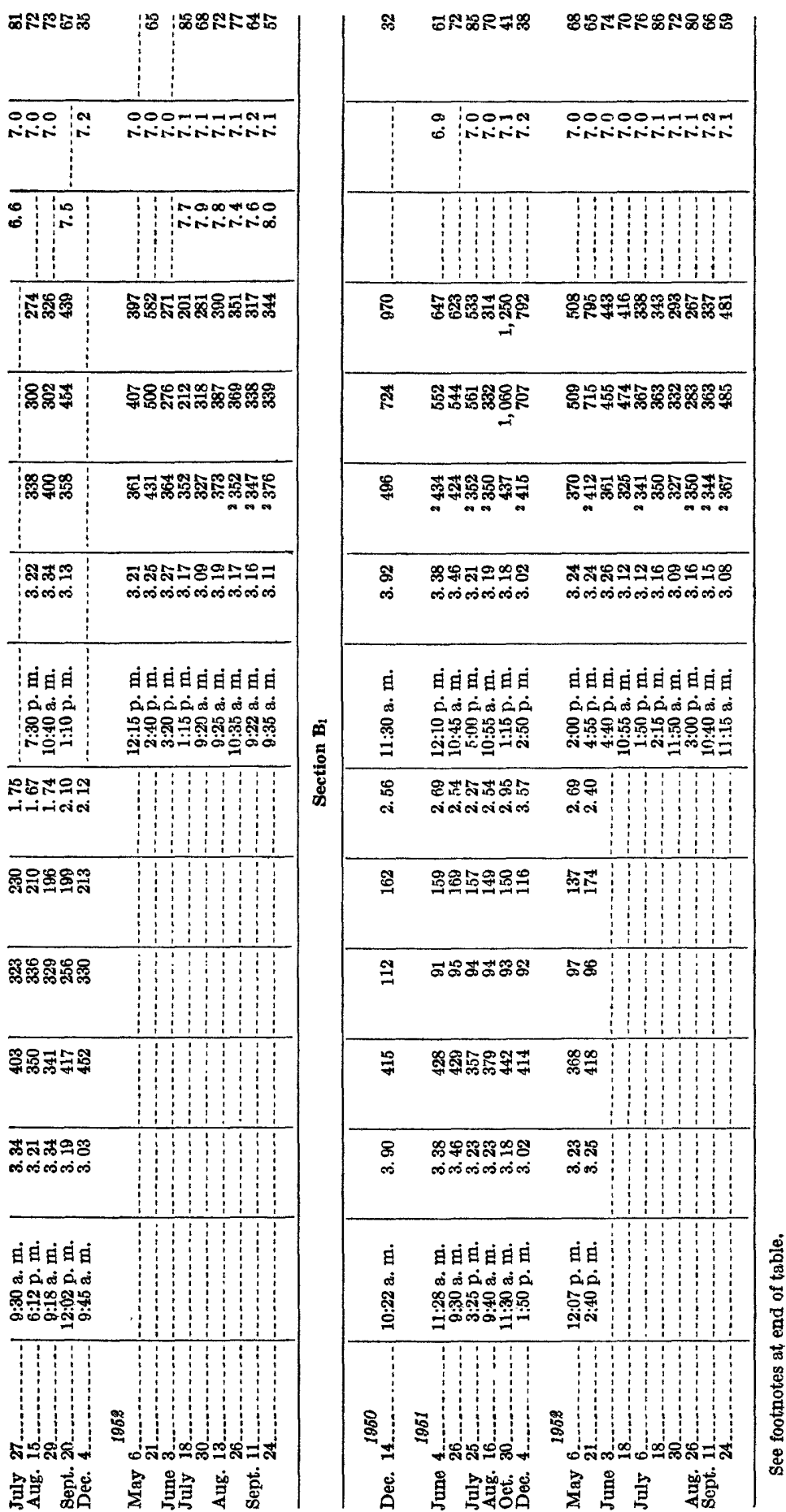


SEDIMENT TRANSPORTATION, MIDDLE LOUP RIVER, NEBR.

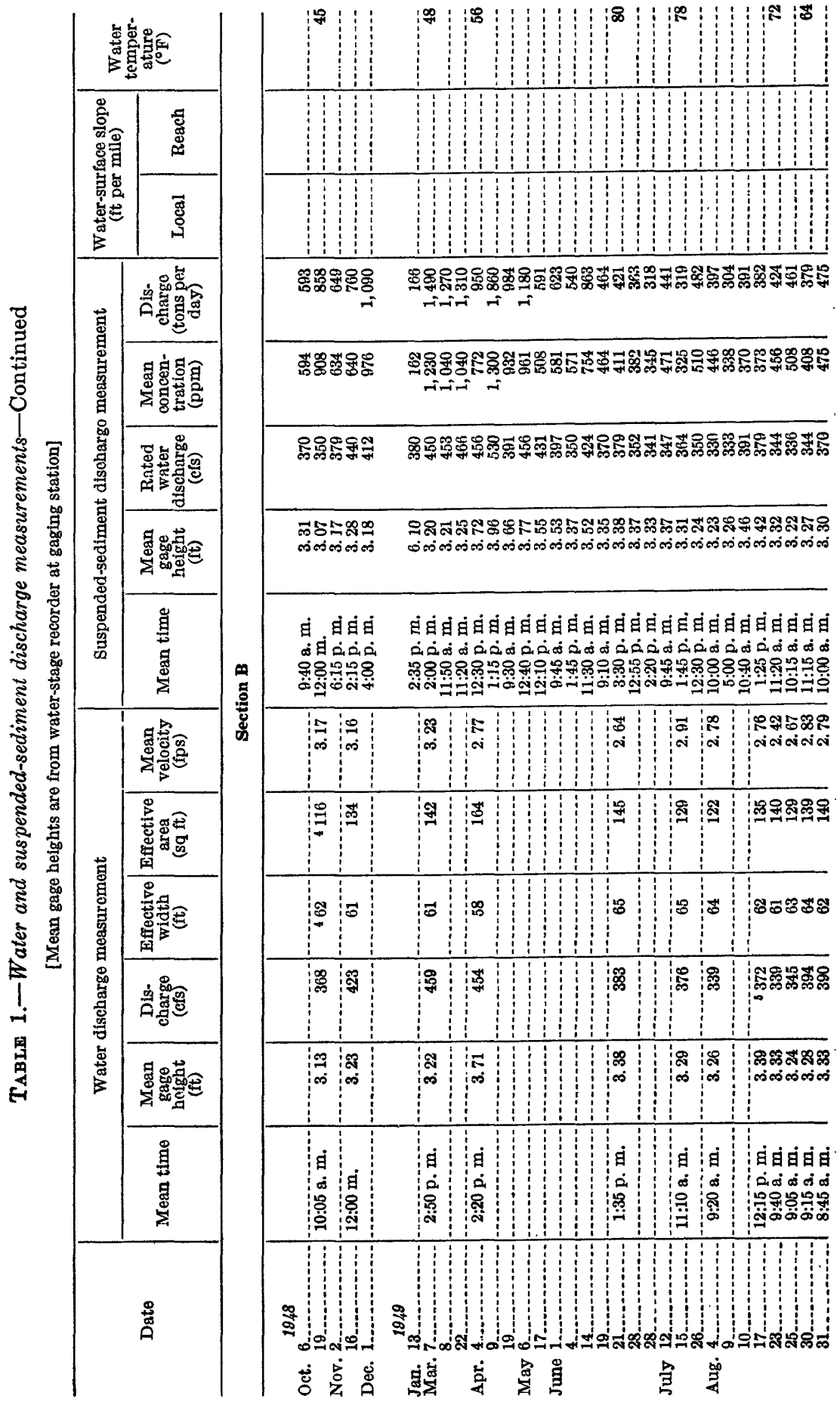


TABLES OF BASIC DATA

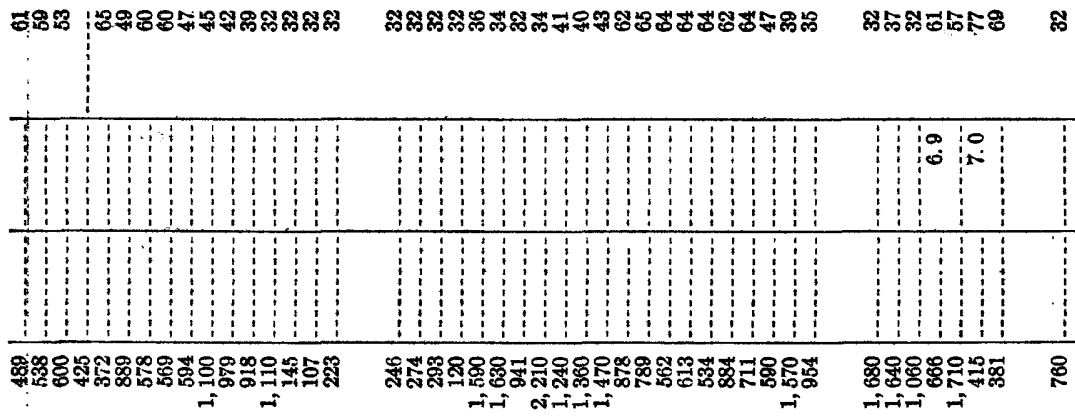

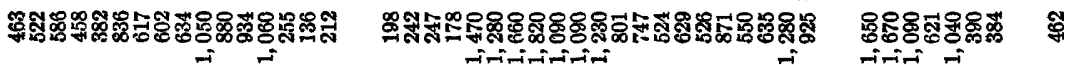

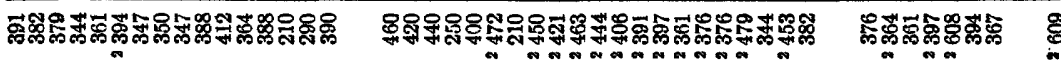

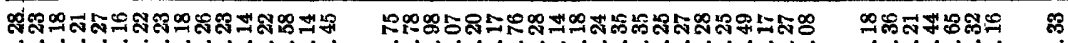

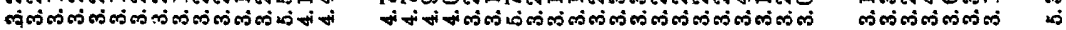

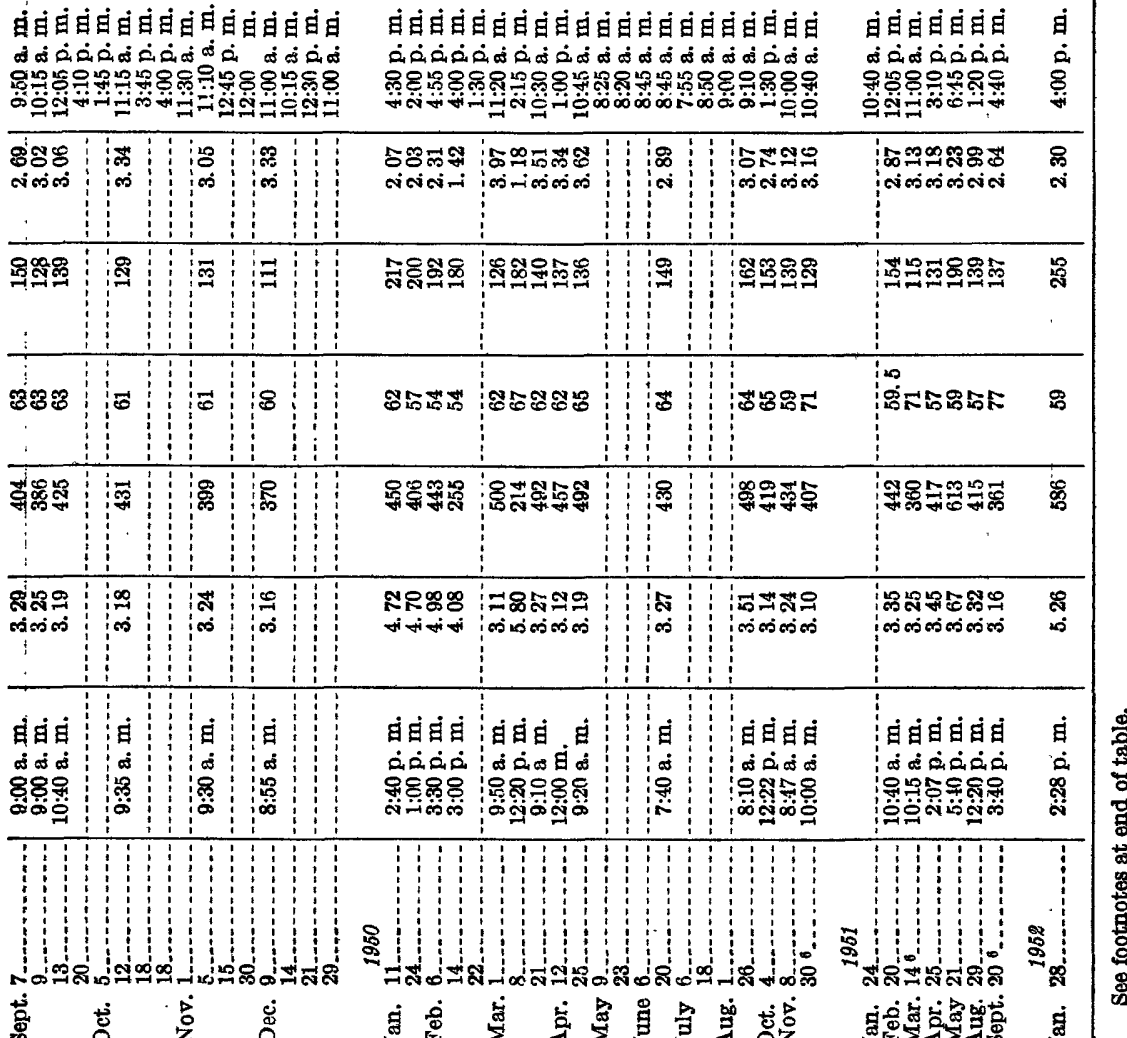


SEDIMENT TRANSPORTATION, MIDDLE LOUP RIVER, NEBR.

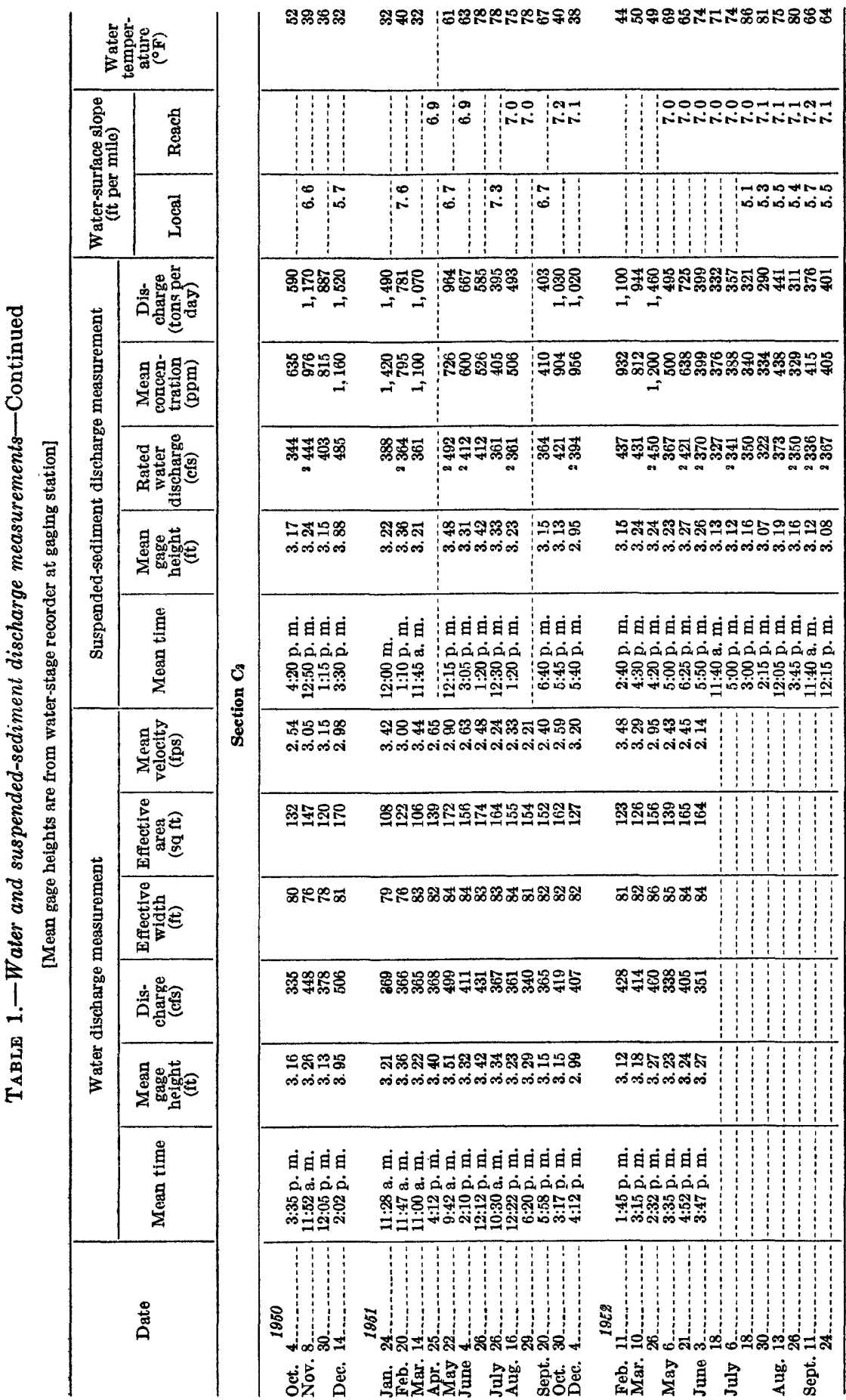


TABLES OF BASIC DATA

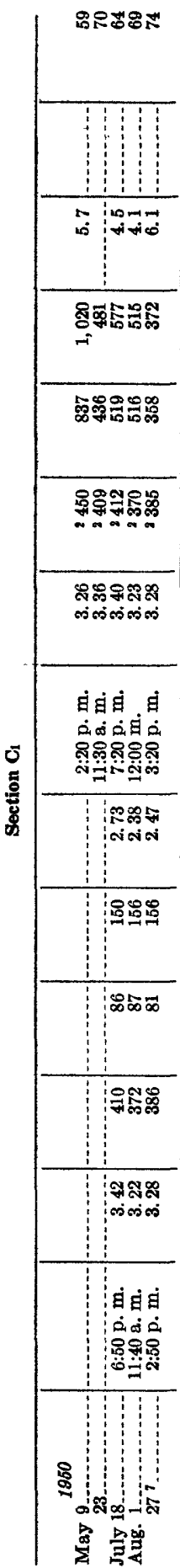

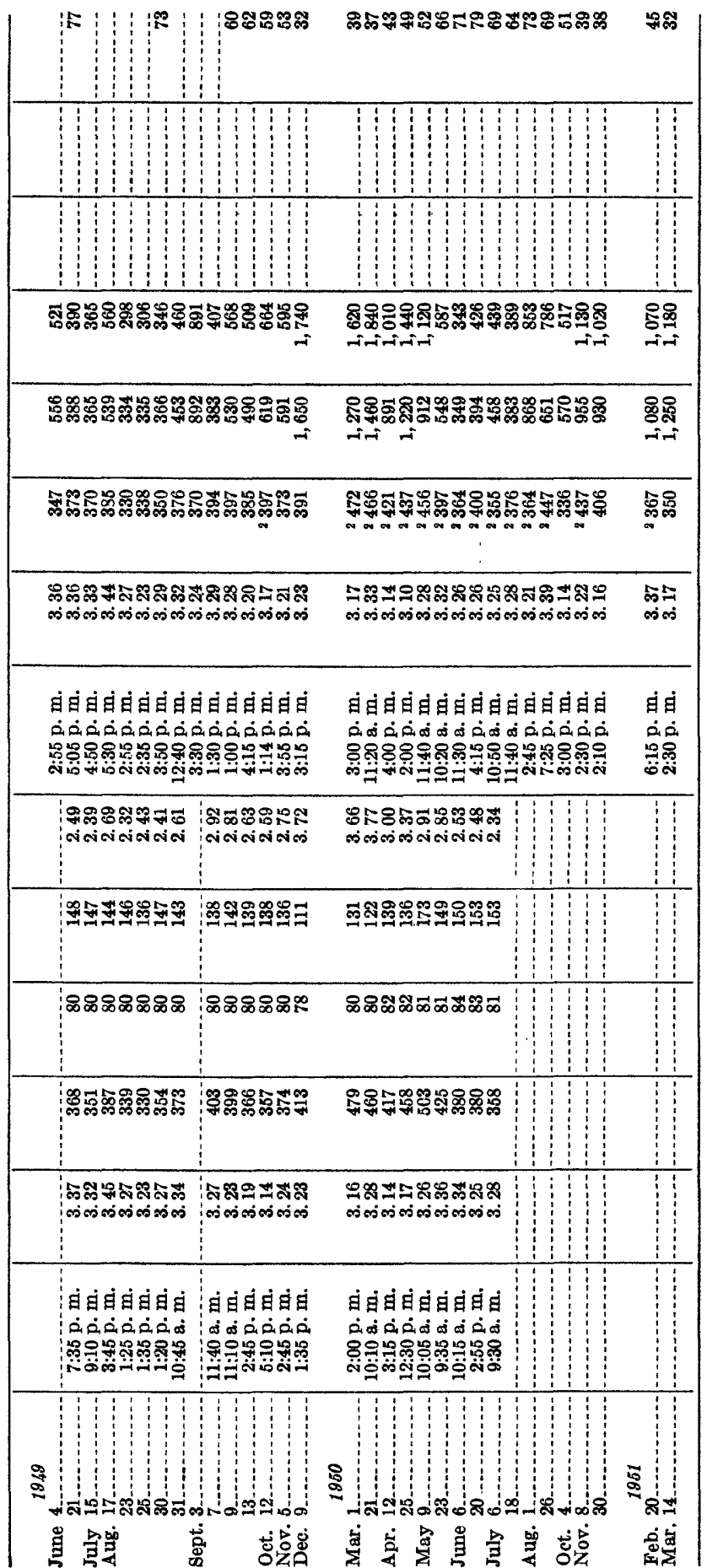


88 SEDIMENT TRANSPORTATION, MIDDLE LOUP RIVER, NEBR.

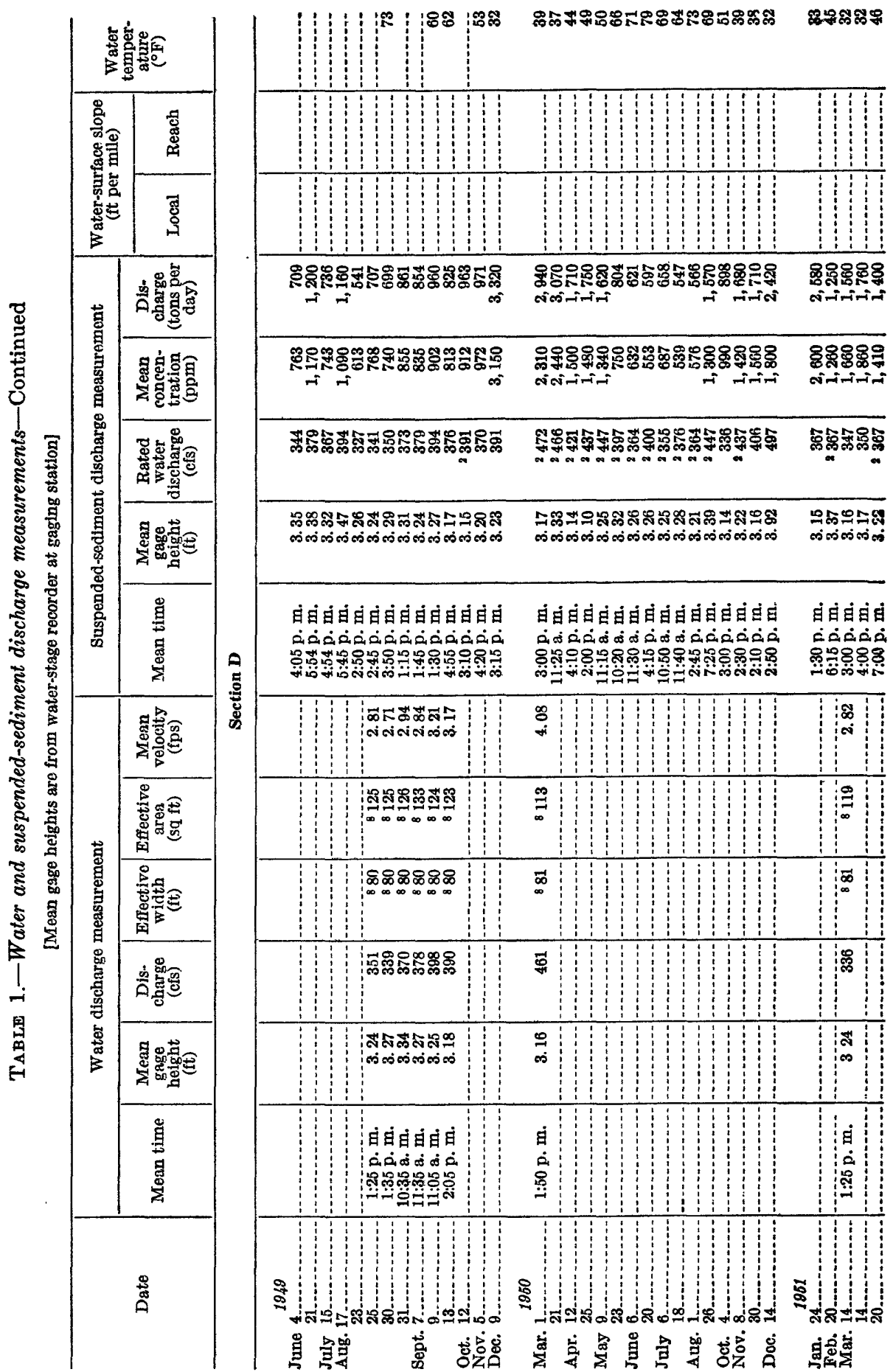



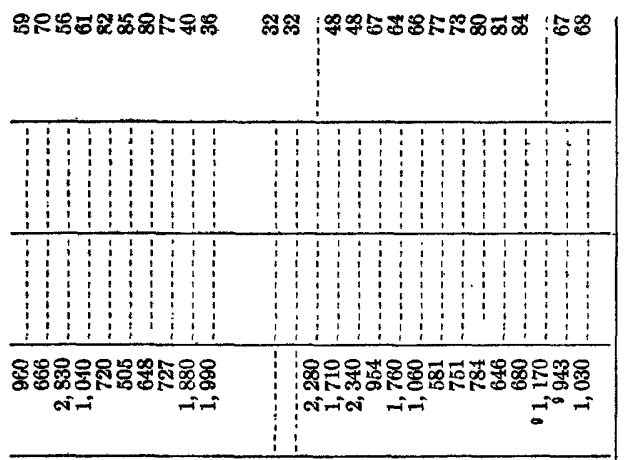

\begin{tabular}{|c|c|}
\hline & \\
\hline 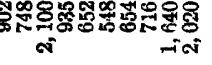 & 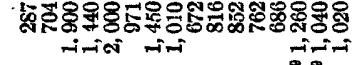 \\
\hline
\end{tabular}

\begin{tabular}{|c|c|}
\hline 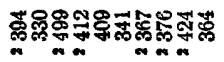 & 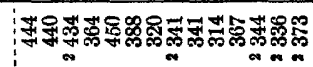 \\
\hline
\end{tabular}

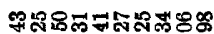

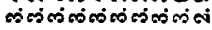

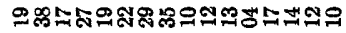

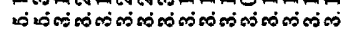

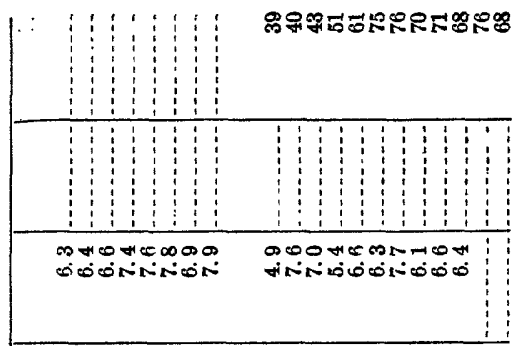

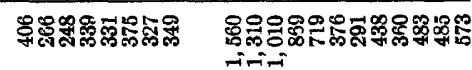

\begin{tabular}{|c|c|}
\hline 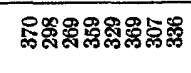 & 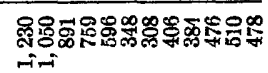 \\
\hline
\end{tabular}

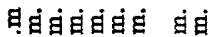

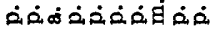

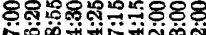

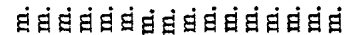

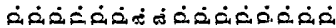

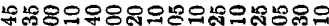 is}

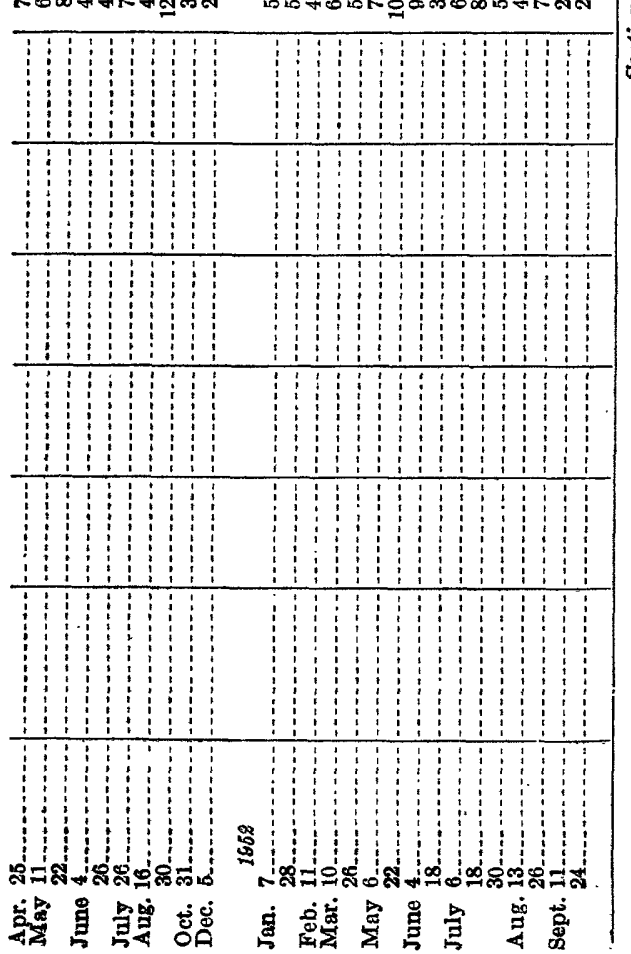

घंघंघंघंघंघंघं

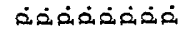

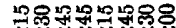

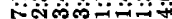

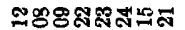
तivinisini

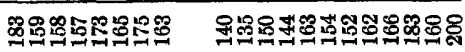

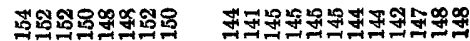

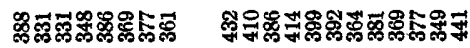

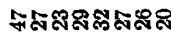

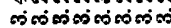

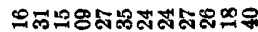

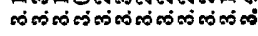

घंघंघ่घंघंघं

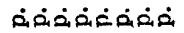

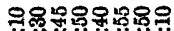

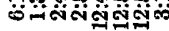

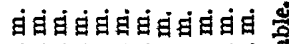

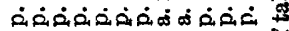

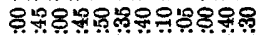

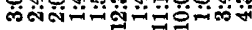

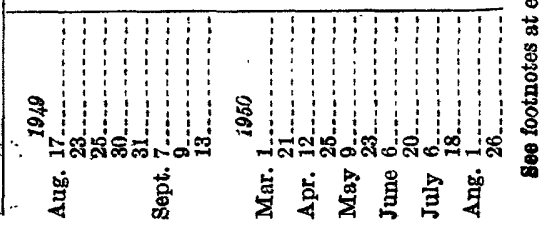




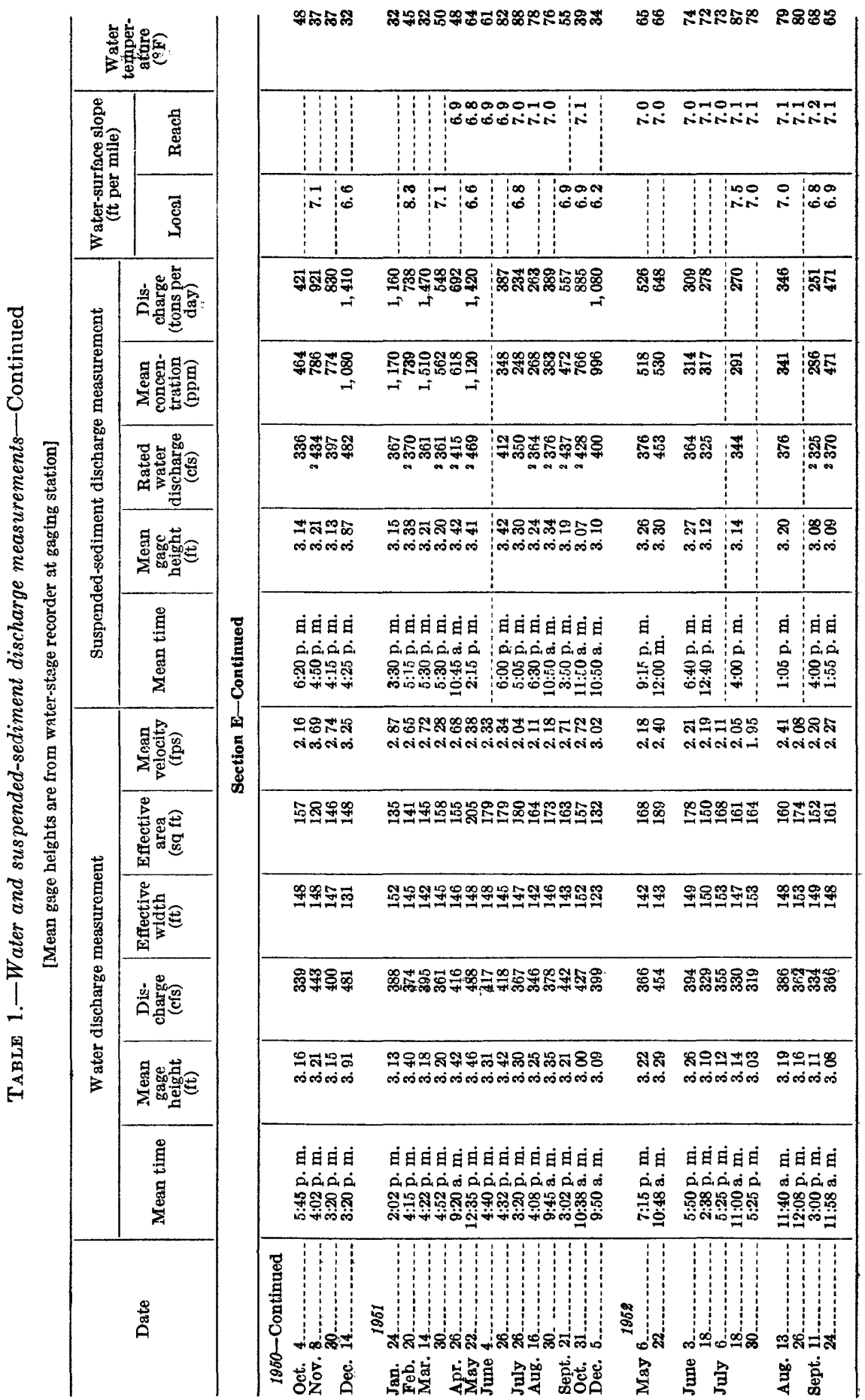


TABLES OF BASIC DATA

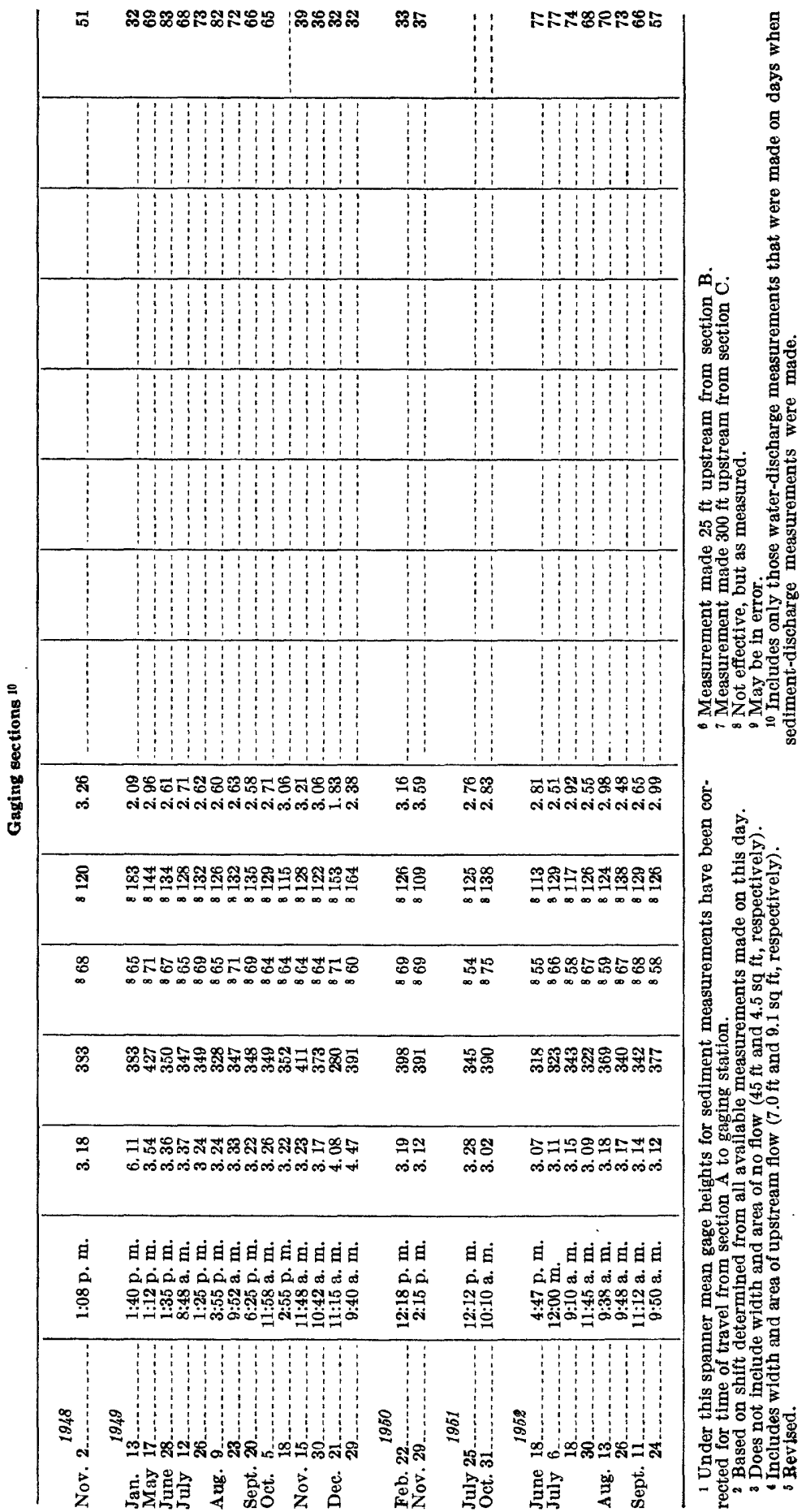


92 SEDIMENT TRANSPORTATION, MIDDLE LOUP RIVER, NEBR.

TABLE 2.-Cross-section soundings

\begin{tabular}{|c|c|c|c|c|c|}
\hline Date & Section & Time & $\begin{array}{c}\text { Mean gage } \\
\text { height } \\
\text { (ft) }\end{array}$ & $\begin{array}{c}\text { Width } \\
\text { (ft) }\end{array}$ & $\begin{array}{l}\text { Area } \\
\text { (sq ft) }\end{array}$ \\
\hline $\begin{array}{r}\text { Sept. } 11 \\
\text { Do } \\
\text { Do } \\
\text { Sept. } 24 \\
\text { Do } \\
\text { Do } \\
\text { Do }\end{array}$ & $\begin{array}{l}\mathrm{A} \\
\mathrm{B}_{1} \\
\mathrm{C}_{2} \\
\mathrm{~A} \\
\mathrm{~B}_{1} \\
\mathrm{C}_{2}\end{array}$ & $\begin{array}{l}11: 08 \text { a. } \mathrm{m} . \\
12: 15 \text { p. } \mathrm{m} . \\
9: 35 \text { a. } \mathrm{m} . \\
11: 15 \text { a. } \mathrm{m} . \\
12: 25 \text { p. } \mathrm{m} .\end{array}$ & $\begin{array}{l}\text { 3. } 13 \\
\text { 3. } 13 \\
\text { 3. } 10 \\
\text { 3. } 08 \\
\text { 3. } 08\end{array}$ & $\begin{array}{r}298 \\
95 \\
77 \\
335 \\
93 \\
83\end{array}$ & $\begin{array}{l}162 \\
143 \\
129 \\
228 \\
135 \\
143\end{array}$ \\
\hline
\end{tabular}




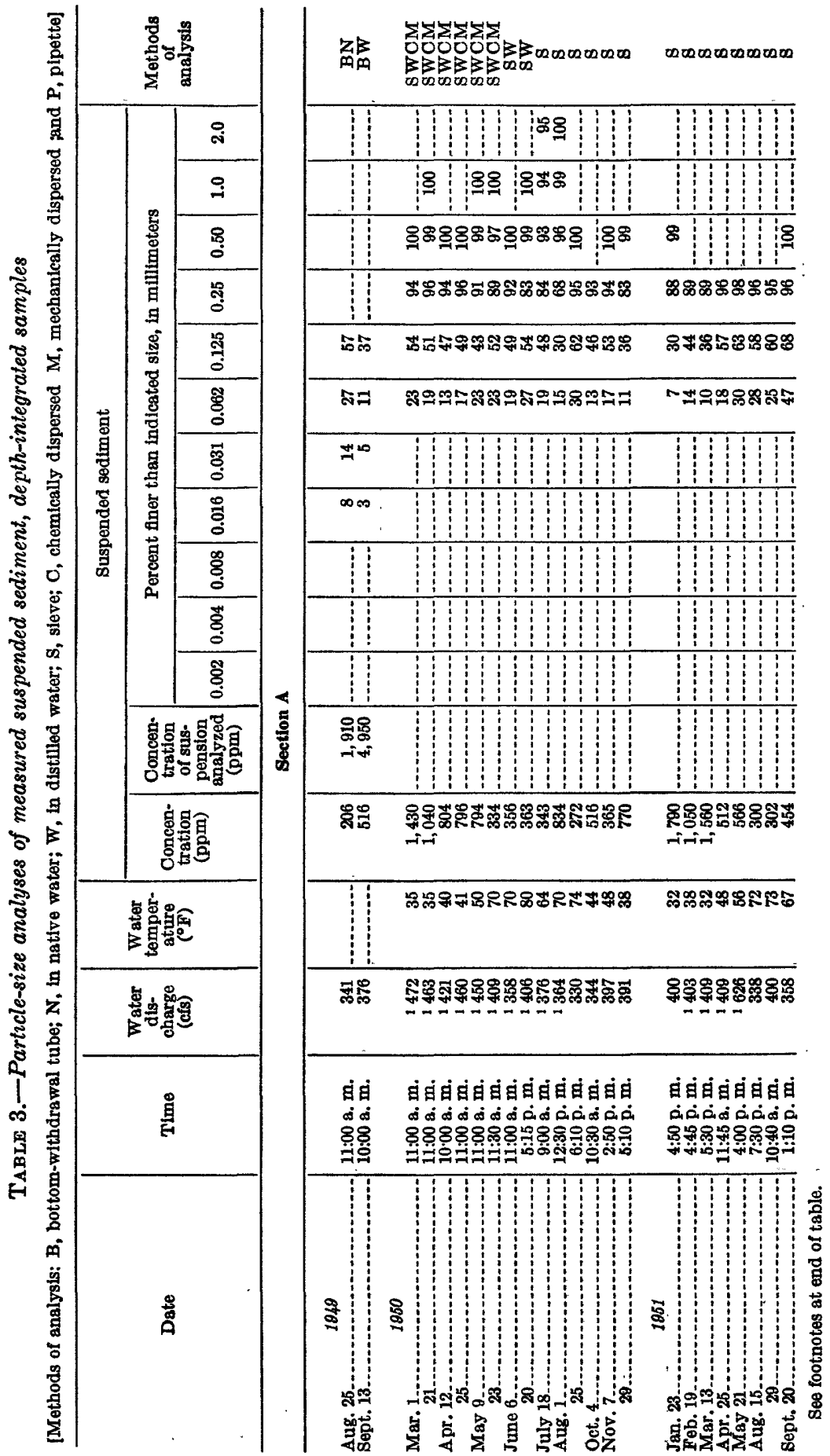


94 SEDIMENT TRANSPORTATION, MTDDLE LOUP RIVER, NEBR.

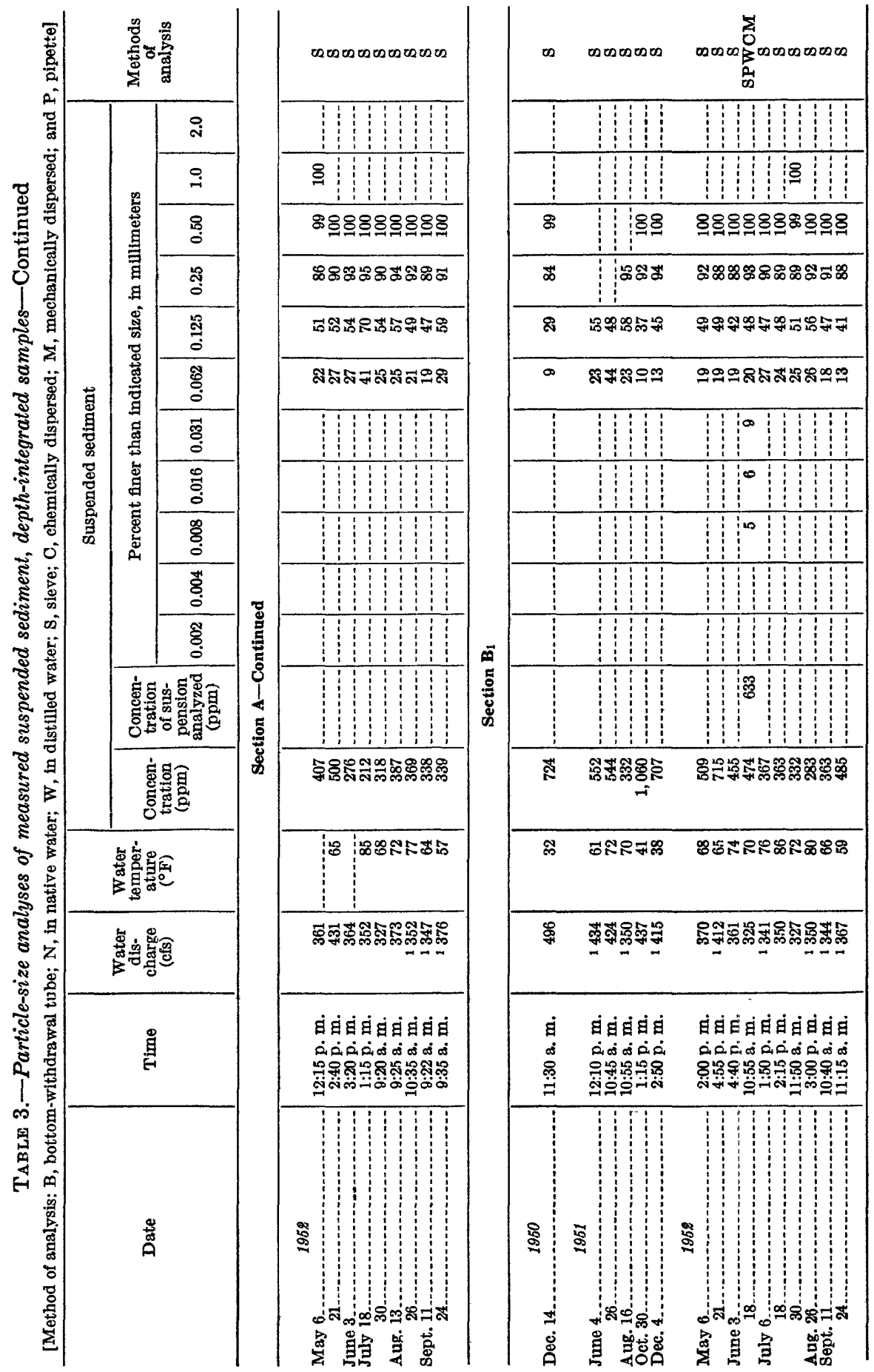




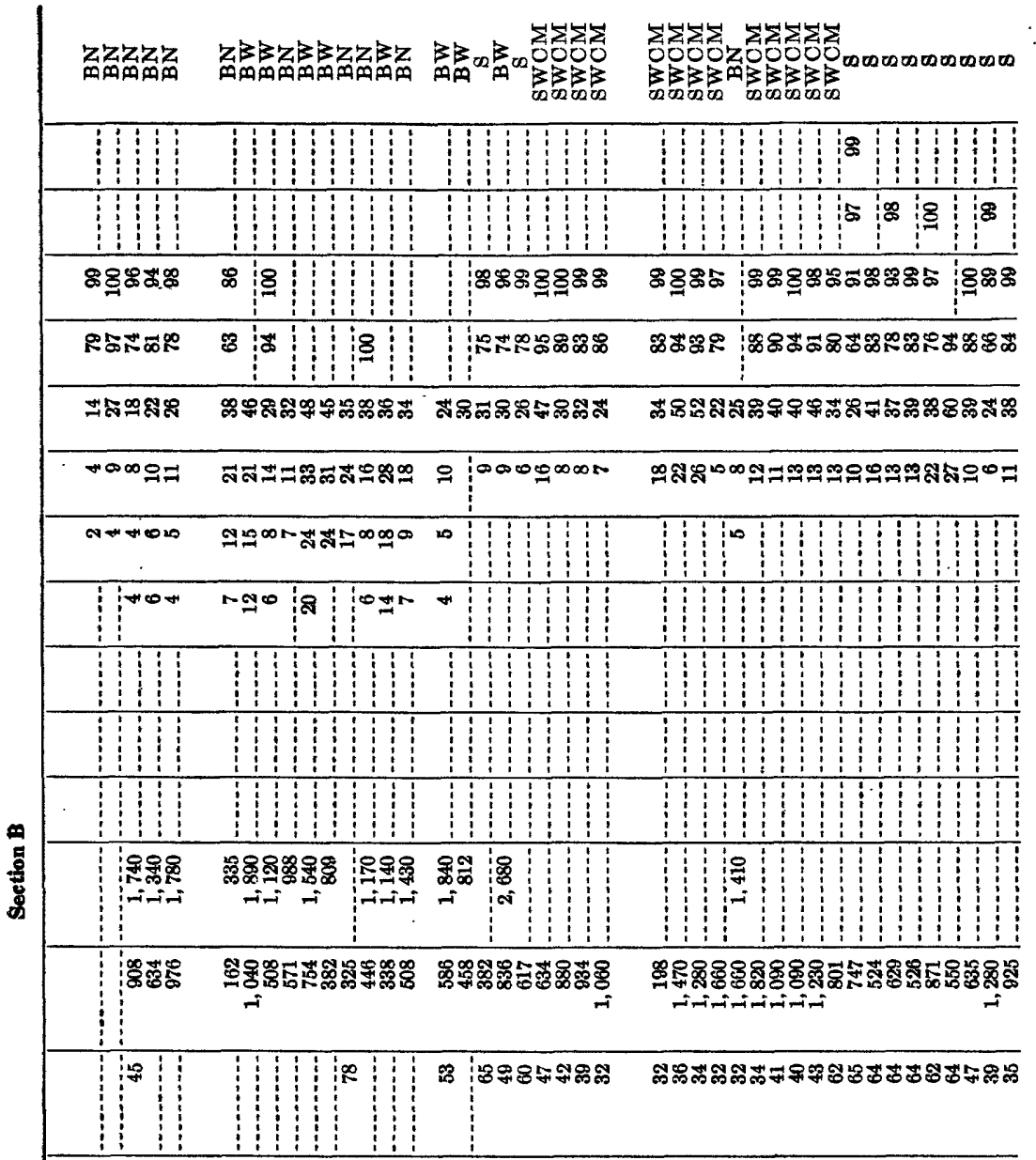

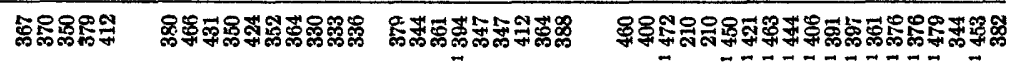

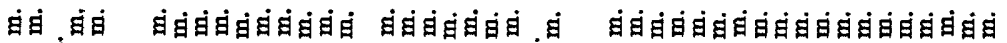

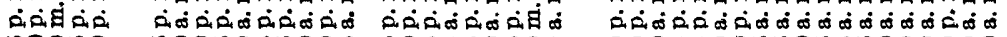

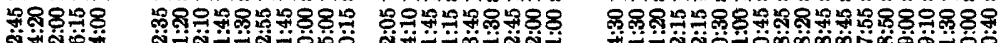

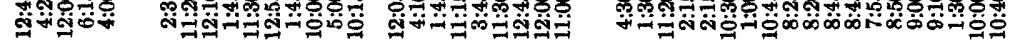

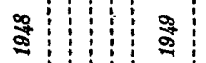

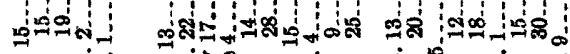

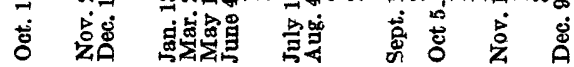
$468443-69-8$

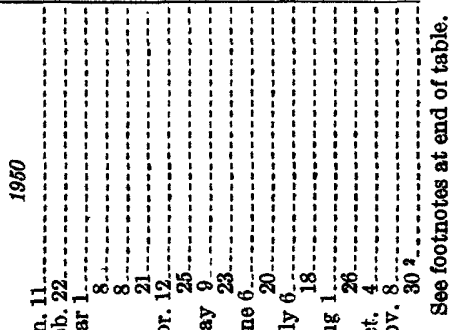


SEDIMENT TRANSPORTATION, MIDDLE LOUP RIVER, NEBR.

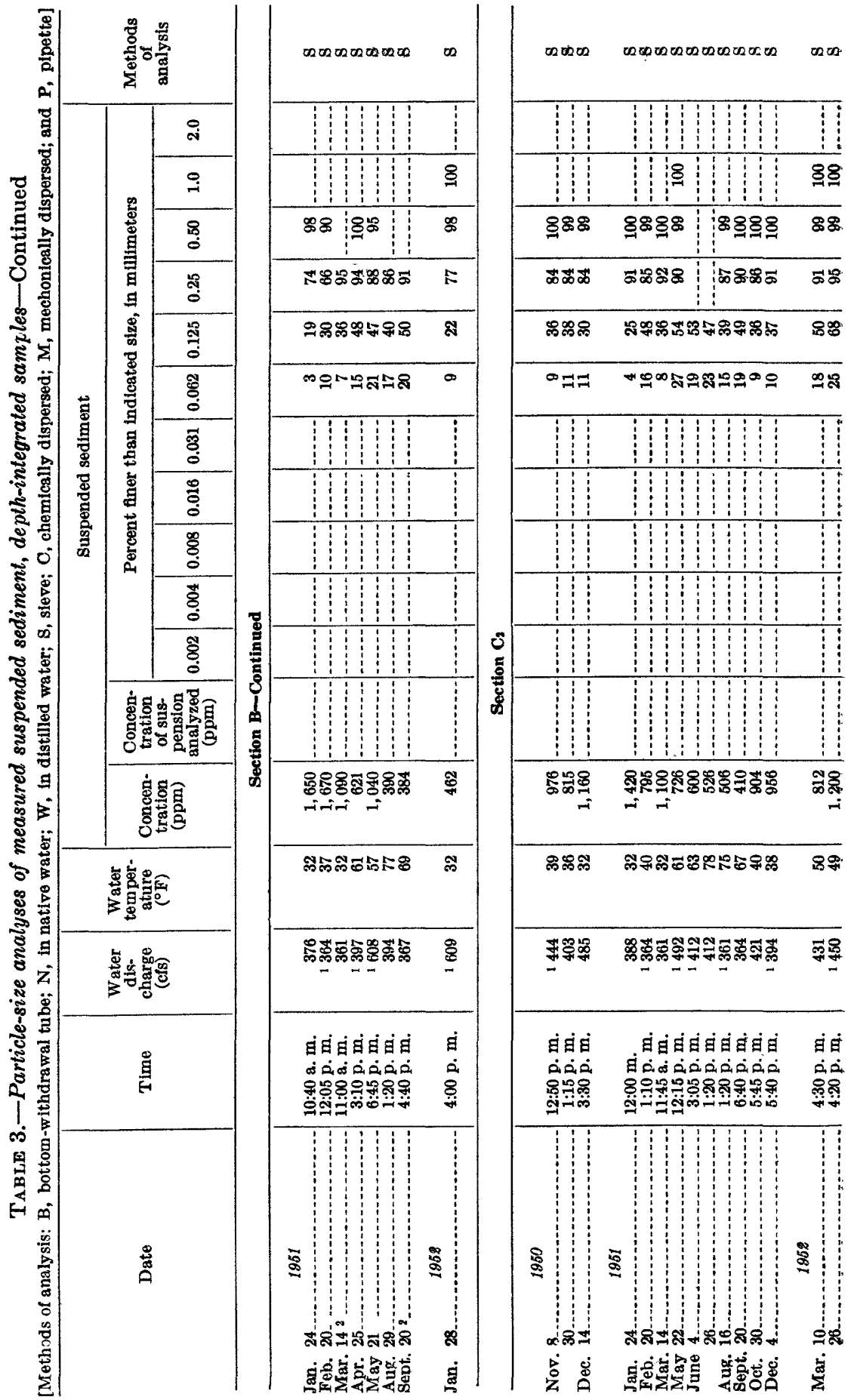




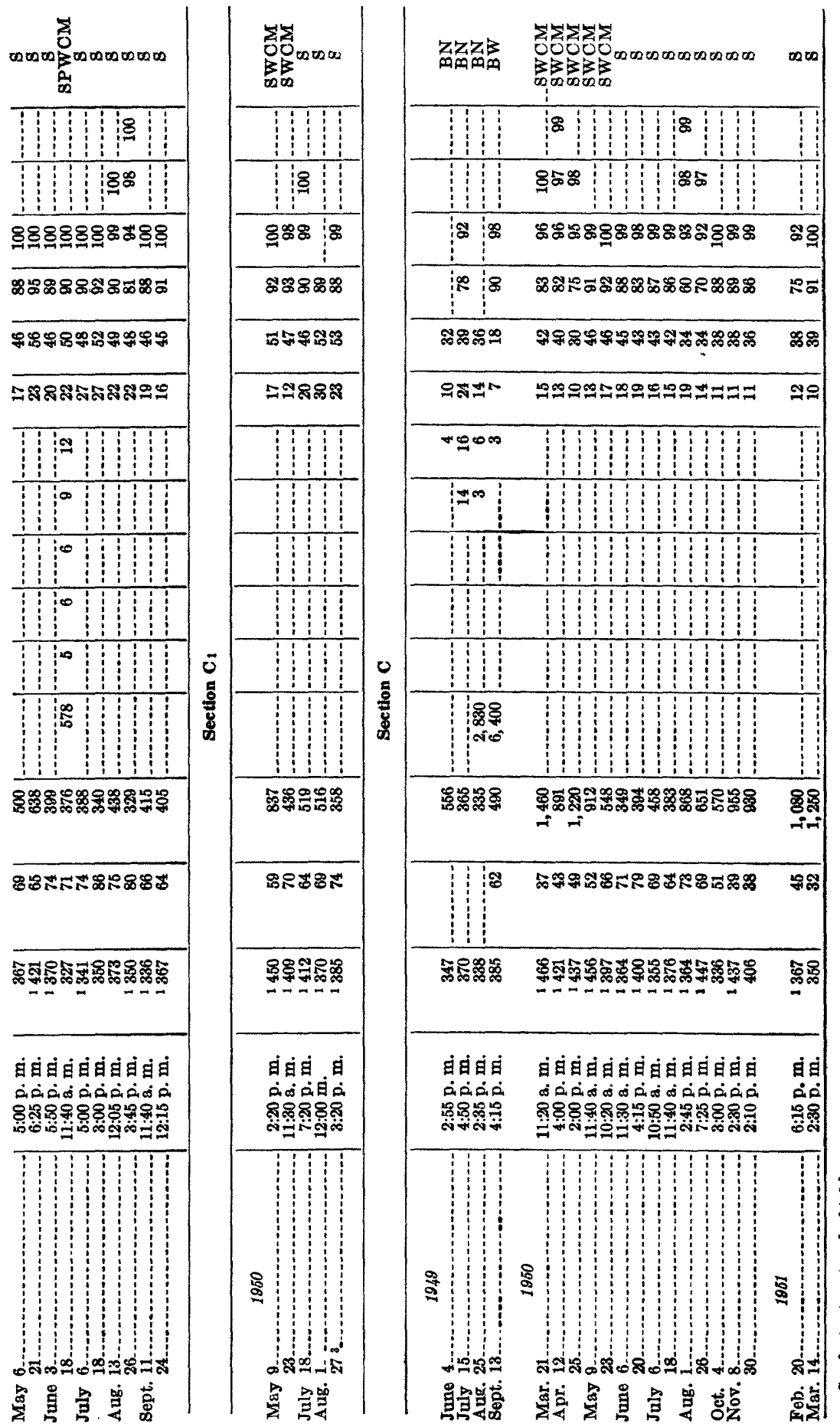




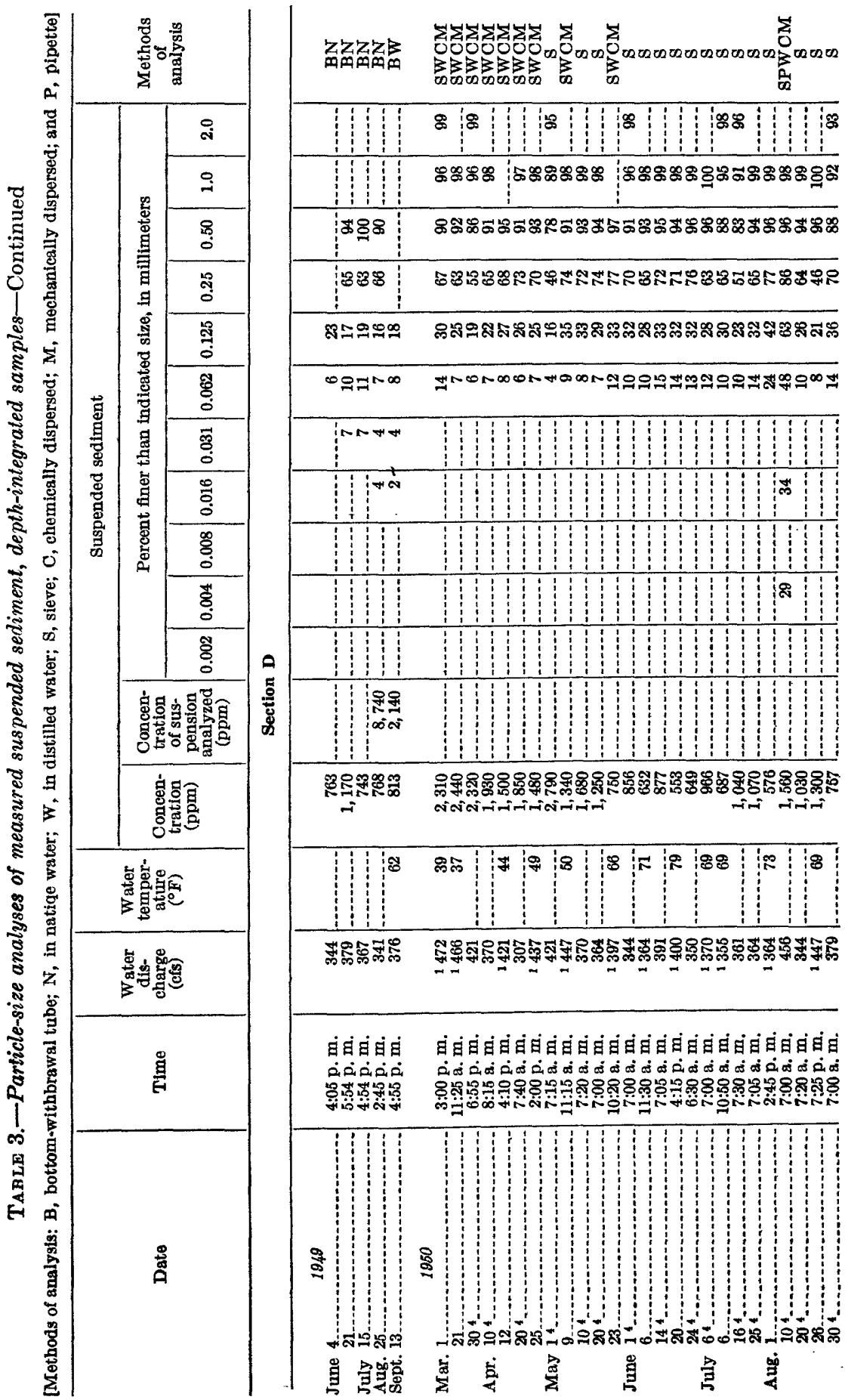




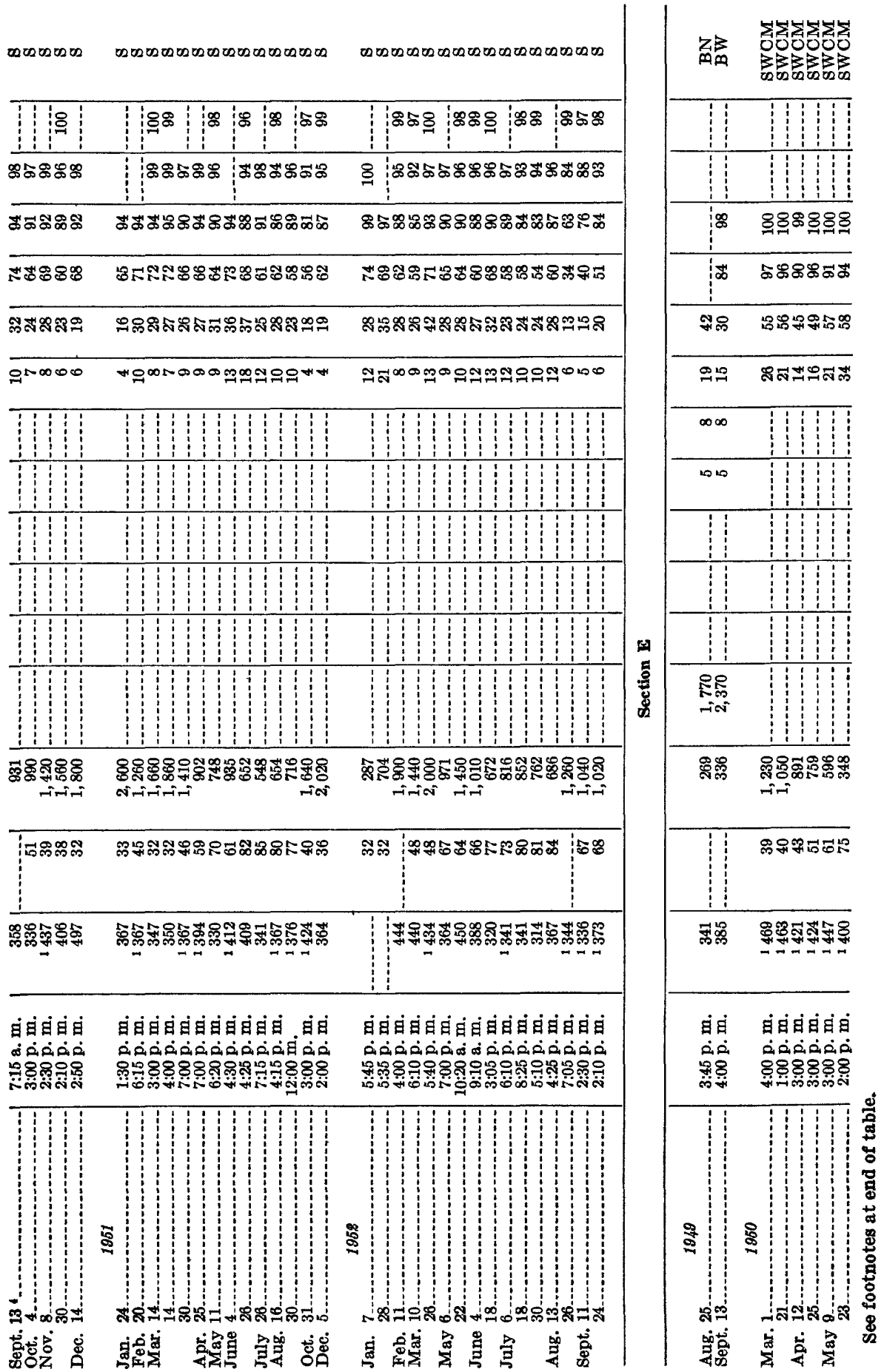


100 SEDIMENT TRANSPORTATION, MIDDLE LOUP RIVER, NEBR.

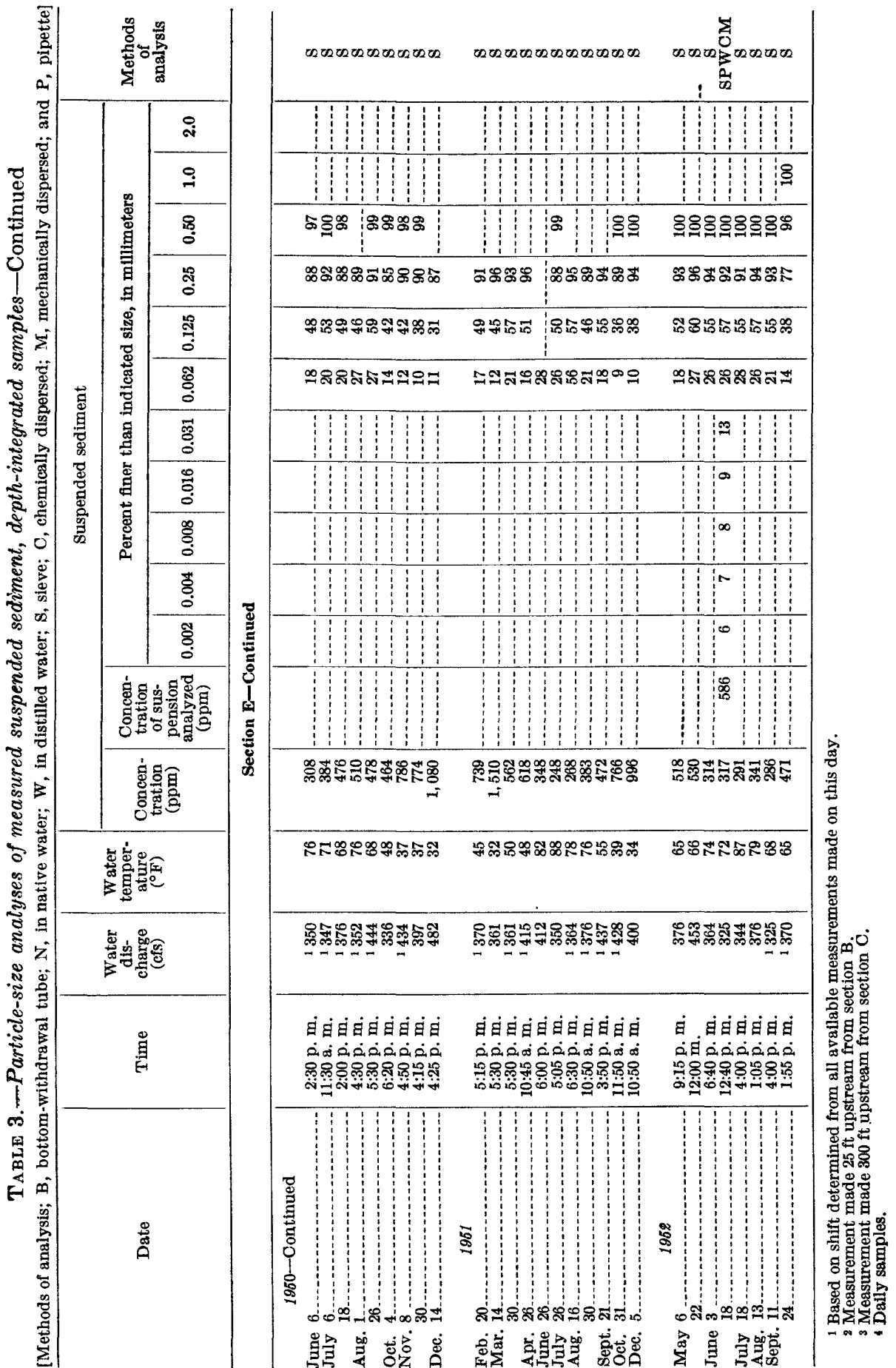


TABLES OF BASIC DATA

TABLE 4.-Particle-size analyses of bed material

[Method of analysis, sieve]

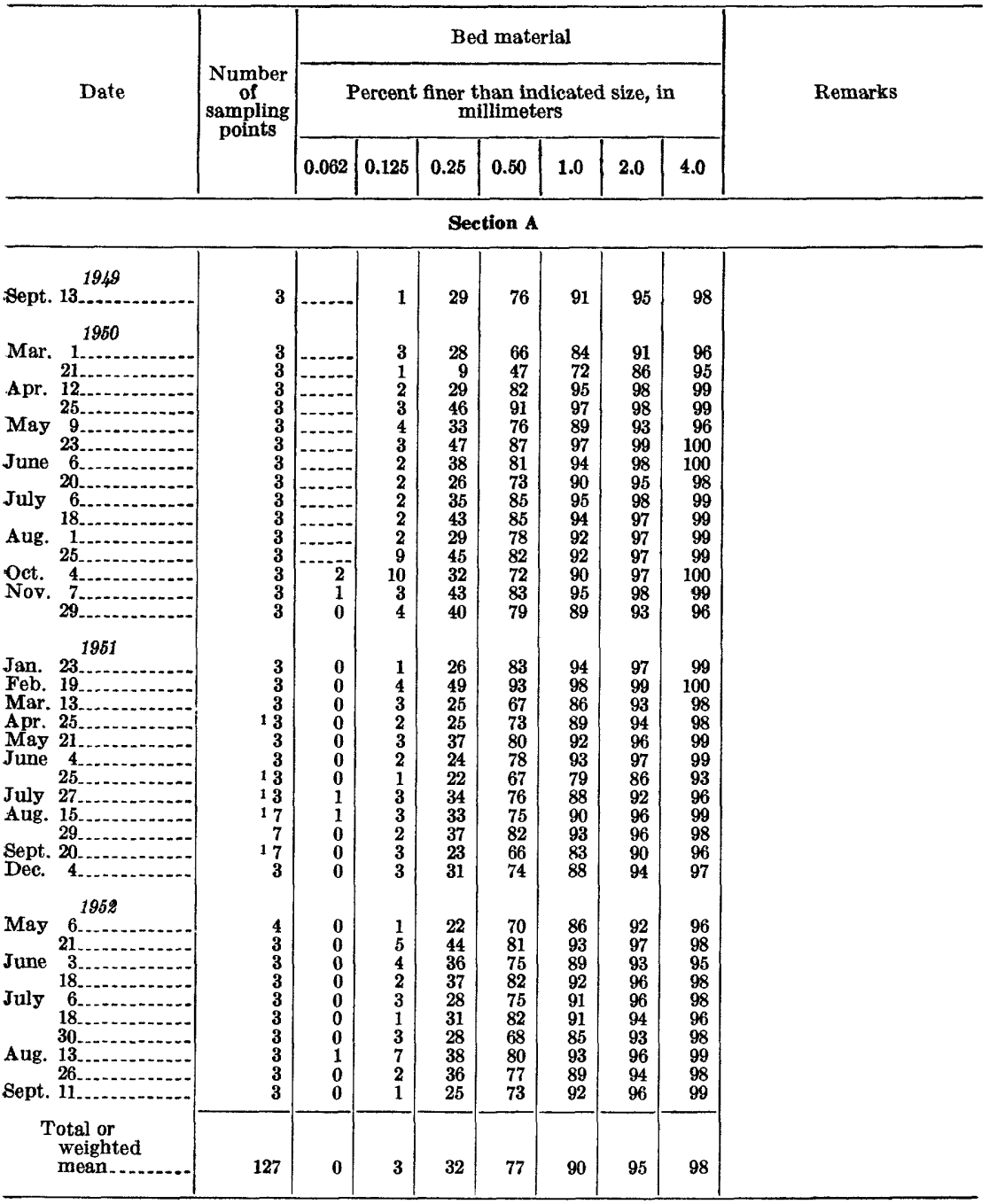

See footnotes at end of table. 
SEDIMENT TRANSPORTATION, MIDDLE LOUP RIVER, NEBR.

TABLE 4.-Particle-size analyses of bed material-Continued

[Method of analysis, sieve]

\begin{tabular}{|c|c|c|c|c|c|c|c|c|c|}
\hline \multirow{3}{*}{ Date } & \multirow{3}{*}{$\begin{array}{l}\text { Number } \\
\text { of } \\
\text { sampling } \\
\text { points }\end{array}$} & \multicolumn{7}{|c|}{ Bed material } & \multirow{3}{*}{ Remarks } \\
\hline & & \multicolumn{7}{|c|}{$\begin{array}{l}\text { Percent finer than indicated size, in } \\
\text { millimeters }\end{array}$} & \\
\hline & & 0.062 & 0.125 & 0.25 & 0.50 & 1.0 & 2.0 & 4.0 & \\
\hline
\end{tabular}

Section $\mathbf{B}_{1}$

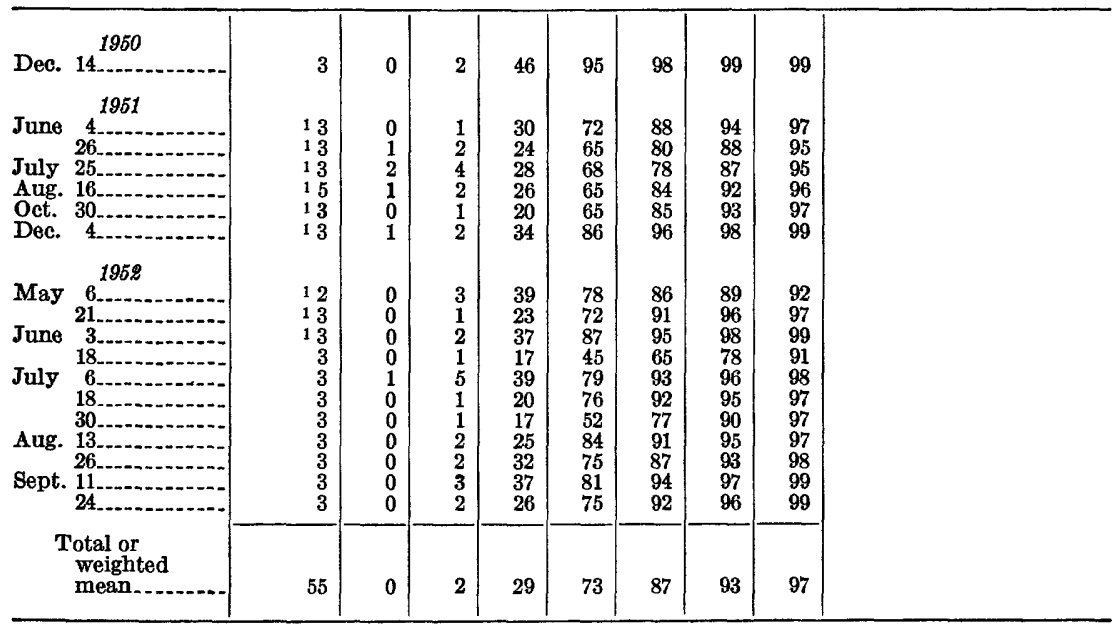

\section{Section B}

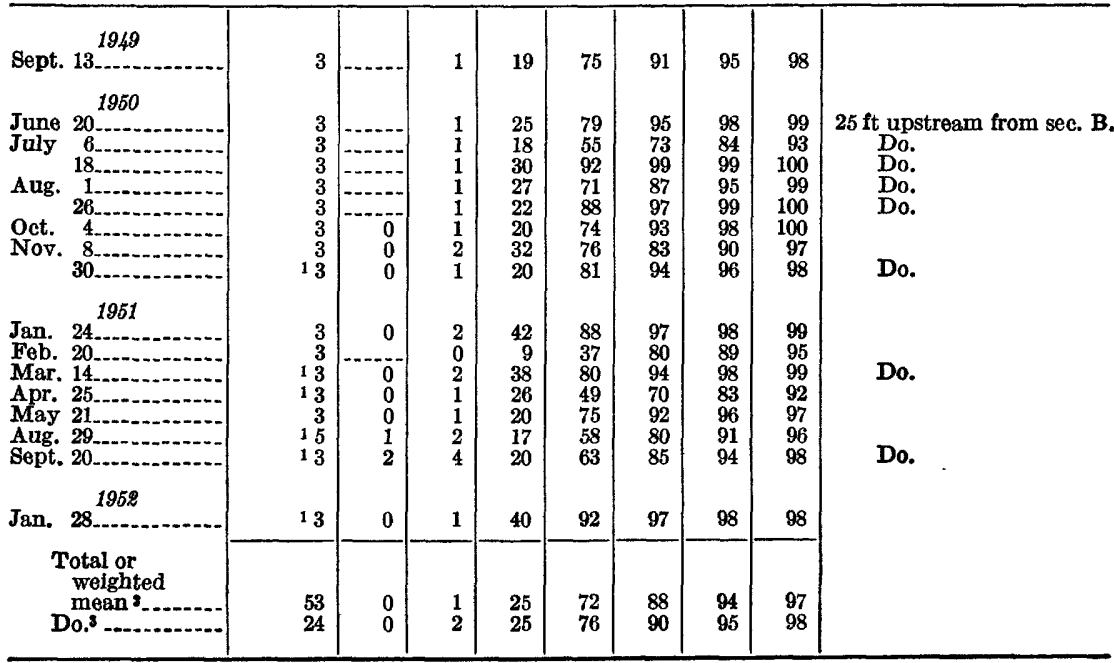

See footnotes at end of table. 
TABLES OF BASIC DATA

TABLE 4.-Particle-size analyses of bed material-Continued

[Method of analysis, sieve]

\begin{tabular}{|c|c|c|c|c|c|c|c|c|c|}
\hline \multirow{3}{*}{ Date } & \multirow{3}{*}{$\begin{array}{c}\text { Number } \\
\text { of } \\
\text { sampling } \\
\text { points }\end{array}$} & \multicolumn{7}{|c|}{ Bed material } & \multirow{3}{*}{ Remarks } \\
\hline & & \multicolumn{7}{|c|}{$\begin{array}{c}\text { Percent finer than indicated size, in } \\
\text { millimeters }\end{array}$} & \\
\hline & & 0.062 & 0.125 & 0.25 & 0.50 & 1.0 & 2.0 & 4.0 & \\
\hline \multicolumn{10}{|c|}{ Section $C_{2}$} \\
\hline \multirow[t]{2}{*}{ 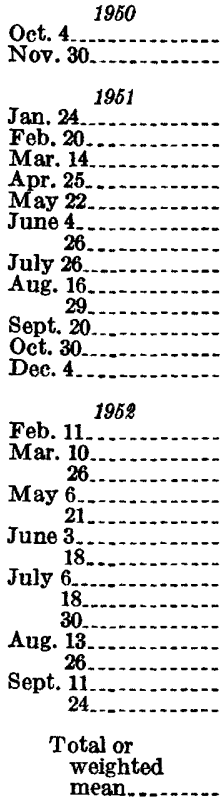 } & $\begin{array}{r}\mathbf{3} \\
\mathbf{3} \\
\\
\mathbf{3} \\
\mathbf{3} \\
\mathbf{1} \mathbf{3} \\
\mathbf{3} \\
1 \mathbf{3} \\
\mathbf{1} \mathbf{3} \\
\mathbf{1} \mathbf{3} \\
\mathbf{1} \mathbf{3} \\
\mathbf{1} \mathbf{7} \\
\mathbf{1} \mathbf{7} \\
\mathbf{1} \mathbf{5} \\
\mathbf{1} \mathbf{3} \\
\mathbf{1} \mathbf{3} \\
\\
\\
\mathbf{3} \\
\mathbf{3} \\
\mathbf{3} \\
\mathbf{1} \mathbf{3} \\
\mathbf{1} \mathbf{3} \\
\mathbf{3} \\
\mathbf{3} \\
\mathbf{3} \\
\mathbf{3} \\
\mathbf{3} \\
\mathbf{3} \\
\mathbf{3} \\
\mathbf{3} \\
\mathbf{3}\end{array}$ & $\begin{array}{l}0 \\
0 \\
\\
\\
0 \\
1 \\
0 \\
0 \\
0 \\
0 \\
0 \\
0 \\
0 \\
0 \\
0 \\
0 \\
0 \\
0 \\
0\end{array}$ & $\begin{array}{l}1 \\
1 \\
\\
1 \\
1 \\
1\end{array}$ & $\begin{array}{r}19 \\
18 \\
\\
28 \\
7 \\
23 \\
12 \\
10 \\
17 \\
13 \\
16 \\
24 \\
23 \\
20 \\
12 \\
26 \\
\\
30 \\
20 \\
24 \\
23 \\
24 \\
25 \\
26 \\
21 \\
24 \\
24 \\
20 \\
19 \\
25 \\
27\end{array}$ & $\begin{array}{l}81 \\
\mathbf{7 3} \\
\\
\mathbf{7 2} \\
33 \\
73 \\
44 \\
45 \\
70 \\
50 \\
60 \\
66 \\
74 \\
65 \\
54 \\
71 \\
\\
\\
81 \\
61 \\
70 \\
67 \\
64 \\
80 \\
78 \\
60 \\
63 \\
78 \\
59 \\
66 \\
80 \\
73\end{array}$ & $\begin{array}{l}\mathbf{9 1} \\
\mathbf{9 0} \\
\\
\mathbf{9 0} \\
\mathbf{6 5} \\
\mathbf{8 8} \\
\mathbf{5 9} \\
\mathbf{6 8} \\
\mathbf{8 4} \\
\mathbf{7 2} \\
\mathbf{7 9} \\
\mathbf{8 5} \\
88 \\
86 \\
80 \\
\mathbf{8 7} \\
\\
\mathbf{9 2} \\
\mathbf{8 4} \\
\mathbf{8 9} \\
\mathbf{8 1} \\
\mathbf{8 0} \\
\mathbf{9 1} \\
\mathbf{9 1} \\
\mathbf{7 7} \\
\mathbf{8 1} \\
\mathbf{8 4} \\
\mathbf{7 9} \\
\mathbf{8 3} \\
\mathbf{9 2} \\
\mathbf{8 9}\end{array}$ & $\begin{array}{l}95 \\
95 \\
\\
96 \\
84 \\
94 \\
72 \\
85 \\
89 \\
83 \\
90 \\
92 \\
94 \\
94 \\
91 \\
93 \\
\\
96 \\
94 \\
92 \\
88 \\
87 \\
94 \\
95 \\
86 \\
91 \\
91 \\
87 \\
92 \\
96 \\
94\end{array}$ & $\begin{array}{l}98 \\
98 \\
\\
99 \\
93 \\
99 \\
\mathbf{8 7} \\
94 \\
\mathbf{9 4} \\
\mathbf{9 1} \\
97 \\
\mathbf{9 7} \\
\mathbf{9 7} \\
98 \\
96 \\
\mathbf{9 6} \\
\\
99 \\
97 \\
\mathbf{9 7} \\
\mathbf{9 7} \\
94 \\
\mathbf{9 4} \\
\mathbf{9 7} \\
\mathbf{9 7} \\
\mathbf{9 4} \\
\mathbf{9 6} \\
\mathbf{9 7} \\
\mathbf{9 4} \\
\mathbf{9 7} \\
\mathbf{9 9} \\
\mathbf{9 8}\end{array}$ & \\
\hline & 97 & 0 & 2 & 21 & 66 & 83 & 91 & 96 & \\
\hline \multicolumn{10}{|c|}{ Section $C_{1}$} \\
\hline 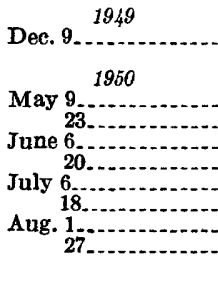 & $\begin{array}{l}\mathbf{3} \\
\mathbf{3} \\
\mathbf{3} \\
\mathbf{3} \\
\mathbf{3} \\
\mathbf{3} \\
\mathbf{3} \\
\mathbf{3}\end{array}$ & \begin{tabular}{|l}
-1 \\
\hdashline-1 \\
-1
\end{tabular} & $\begin{array}{l}4 \\
2 \\
1 \\
1 \\
2 \\
1 \\
1 \\
1\end{array}$ & $\begin{array}{l}39 \\
\\
\\
35 \\
29 \\
21 \\
35 \\
29 \\
32 \\
27 \\
26\end{array}$ & $\begin{array}{l}90 \\
\\
\\
92 \\
75 \\
70 \\
89 \\
75 \\
87 \\
76 \\
85\end{array}$ & $\begin{array}{l}98 \\
89 \\
86 \\
96 \\
92 \\
96 \\
90 \\
96\end{array}$ & $\begin{array}{l}99 \\
94 \\
92 \\
97 \\
96 \\
98 \\
95 \\
98\end{array}$ & $\begin{array}{r}99 \\
\\
99 \\
97 \\
98 \\
99 \\
98 \\
99 \\
98 \\
100\end{array}$ & $\begin{array}{l}95 \mathrm{ft} \text { downstream from sec. } \\
\mathrm{C}_{1 .} \\
105 \mathrm{ft} \text { upstream from sec. } \\
\mathrm{C}_{\mathrm{I}} \text {. }\end{array}$ \\
\hline $\begin{array}{l}\text { Total or } \\
\text { weighted } \\
\text { mean }\end{array}$ & 21 & $\cdots$ & 2 & $\mathbf{3 0}$ & 81 & 92 & 96 & 98 & \\
\hline
\end{tabular}

See footnotes at end of table. 
104 SEDIMENT TRANSPORTATION, MIDDLE LOUP RIVER, NEBR.

TABLE 4.-Particle-size analyses of bed material-Continued

[Method of analysis, sieve]

\begin{tabular}{|c|c|c|c|c|c|c|c|c|c|}
\hline \multirow{3}{*}{ Date } & \multirow{3}{*}{$\begin{array}{l}\text { Number } \\
\text { of } \\
\text { sampling } \\
\text { points }\end{array}$} & \multicolumn{7}{|c|}{ Bed material } & \multirow{3}{*}{ Remarks } \\
\hline & & \multicolumn{7}{|c|}{$\begin{array}{l}\text { Percent finer than indicated size, in } \\
\text { millimeters }\end{array}$} & \\
\hline & & 0.062 & 0.125 & 0.25 & 0.50 & 1.0 & 2.0 & 4.0 & \\
\hline
\end{tabular}

Section C

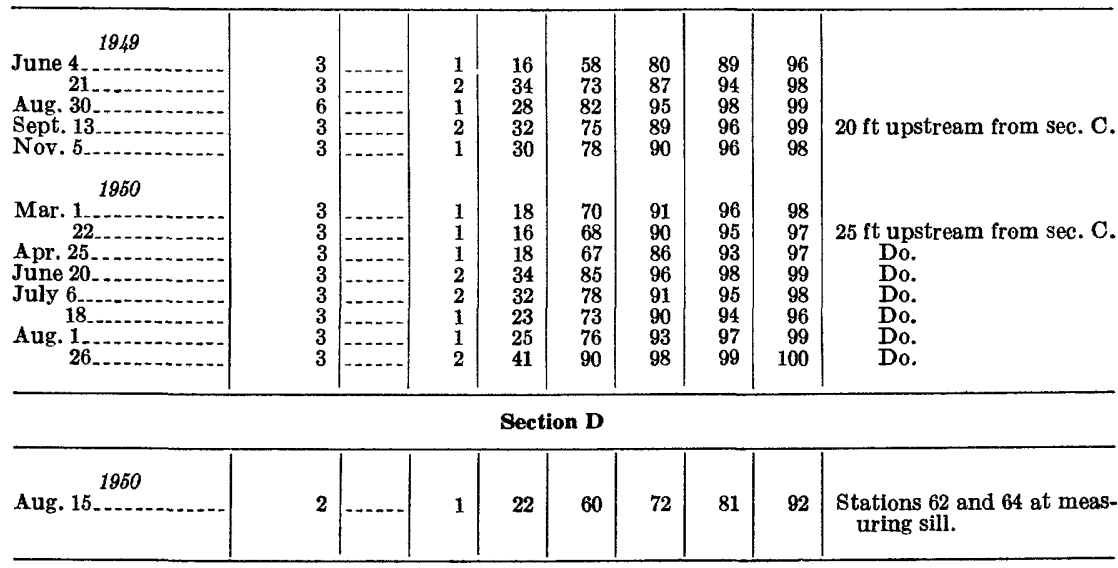

Section $\mathbf{E}$

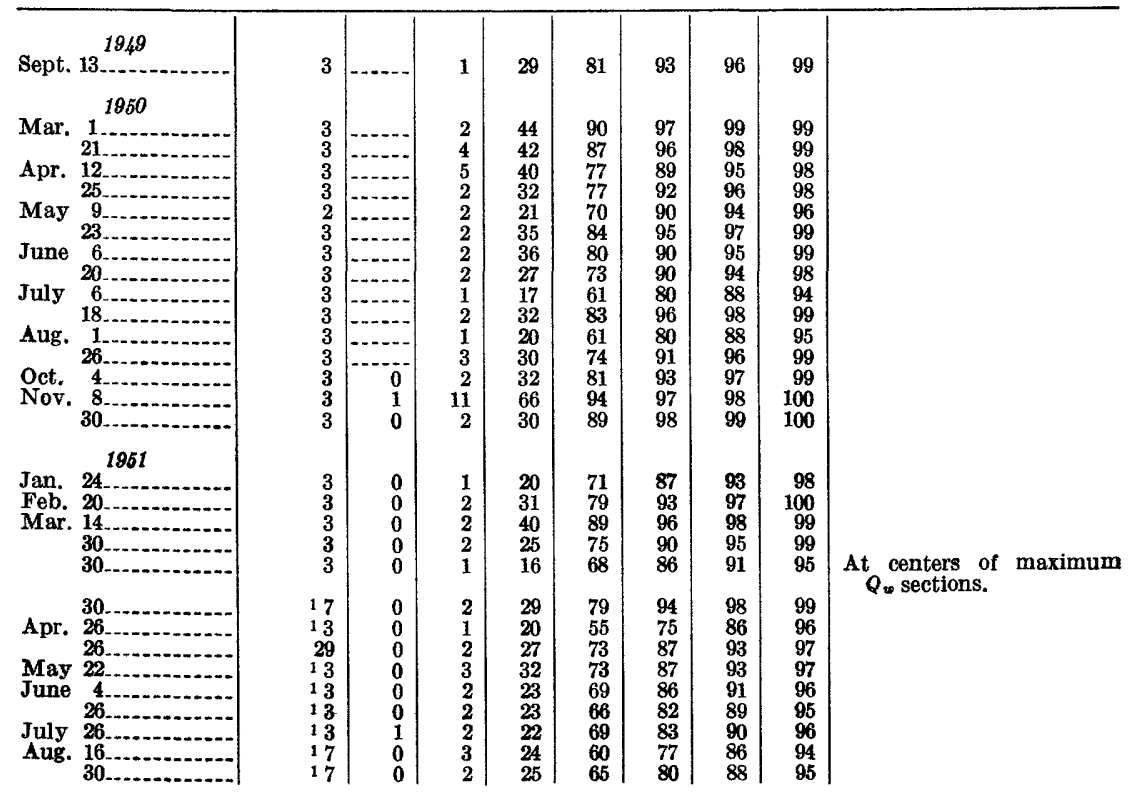

See footnotes at end of table. 
TABLES OF BASIC DATA

TABLE 4.-Particle-size analyses of bed material-Continued

[Method of analysis, sieve]

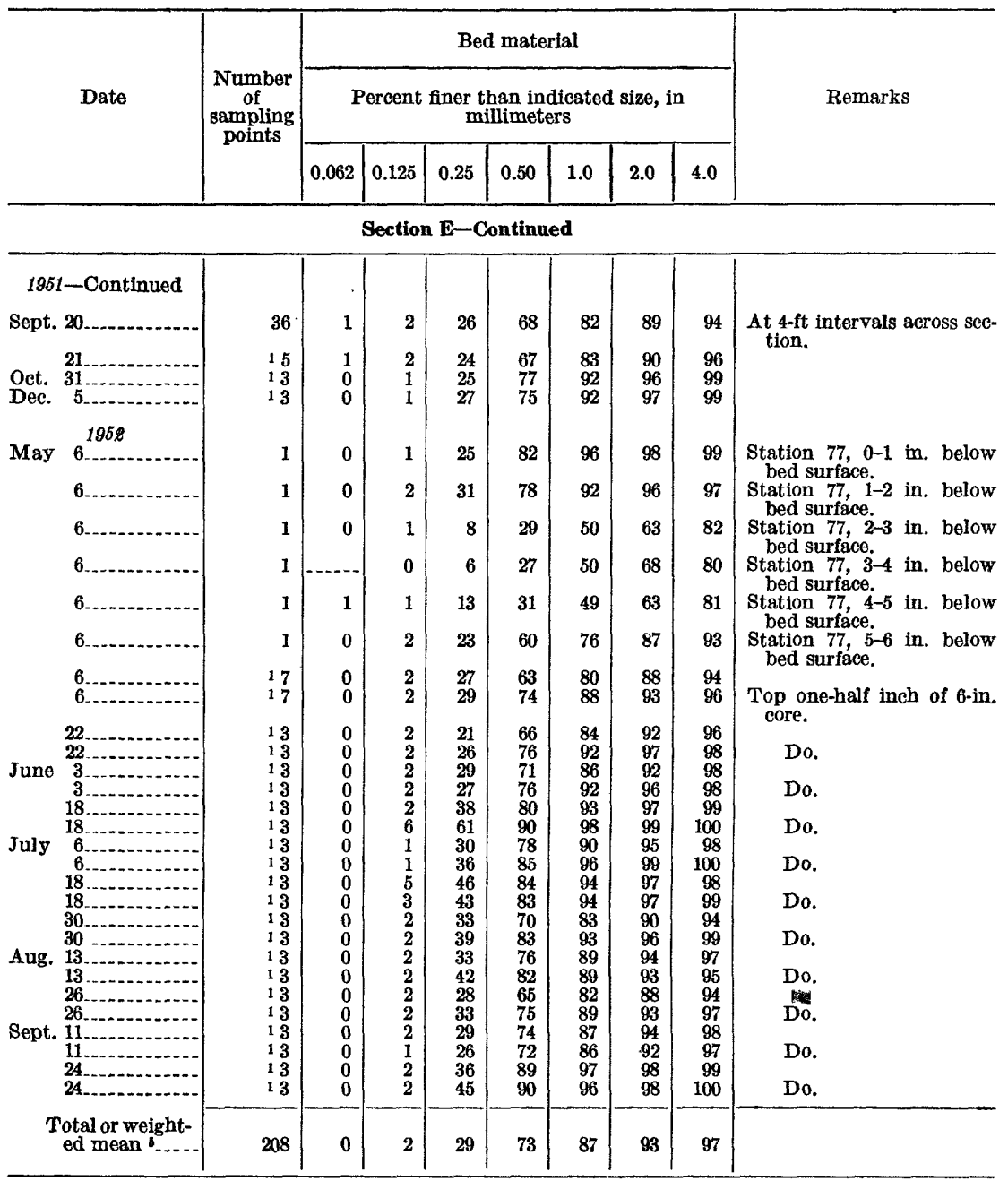

1 Sampling points at centers of equal segments of water discharge.

2 For all samples.

3 For samples $25 \mathrm{ft}$ upstream from sec. $B$.

4 For samples at sec. $C_{1}$.

For all samples except at centers of maximum water discharge sections, station 77 on $\mathrm{May} 6,1952$, and top one-half inch of 6 -in. core. 


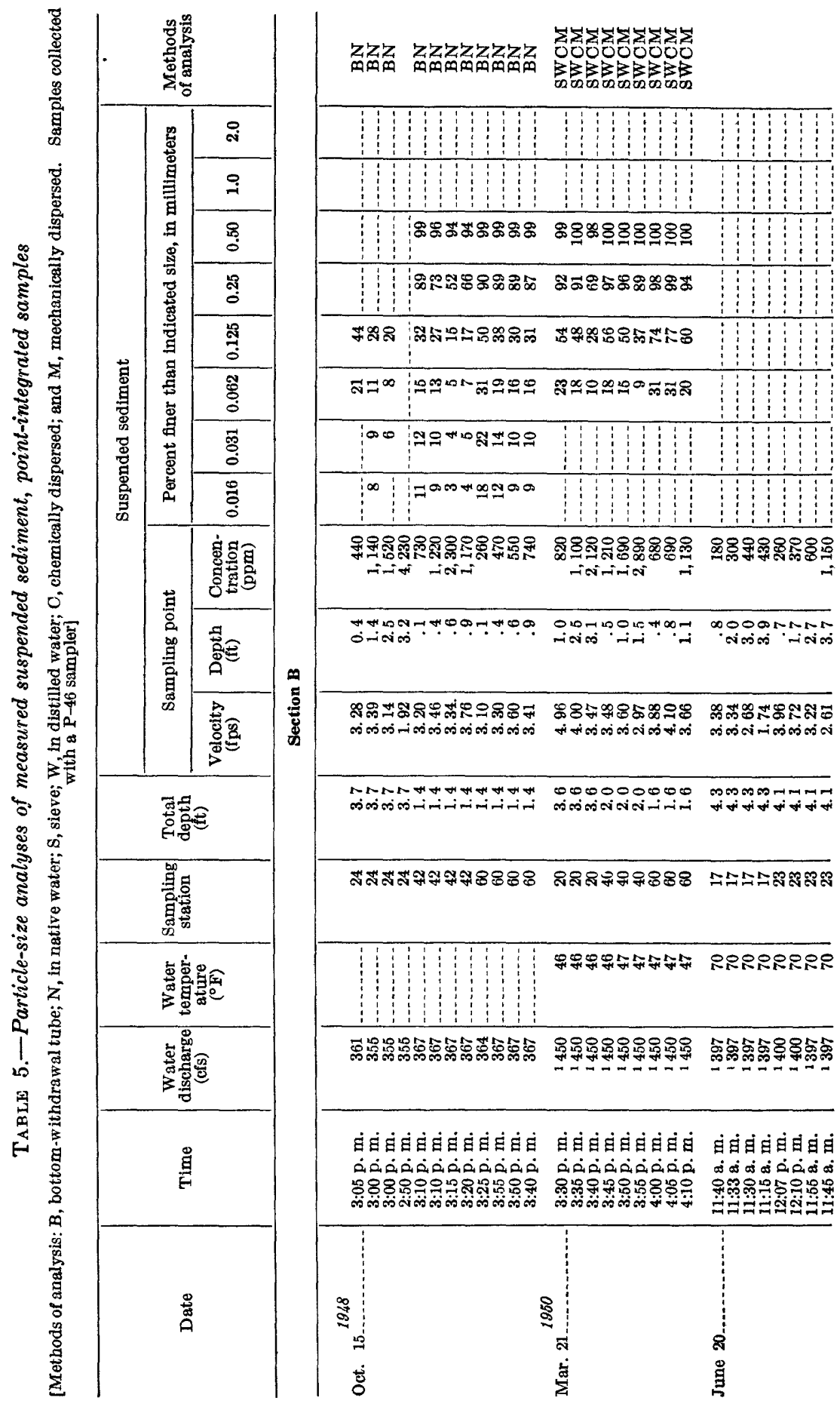




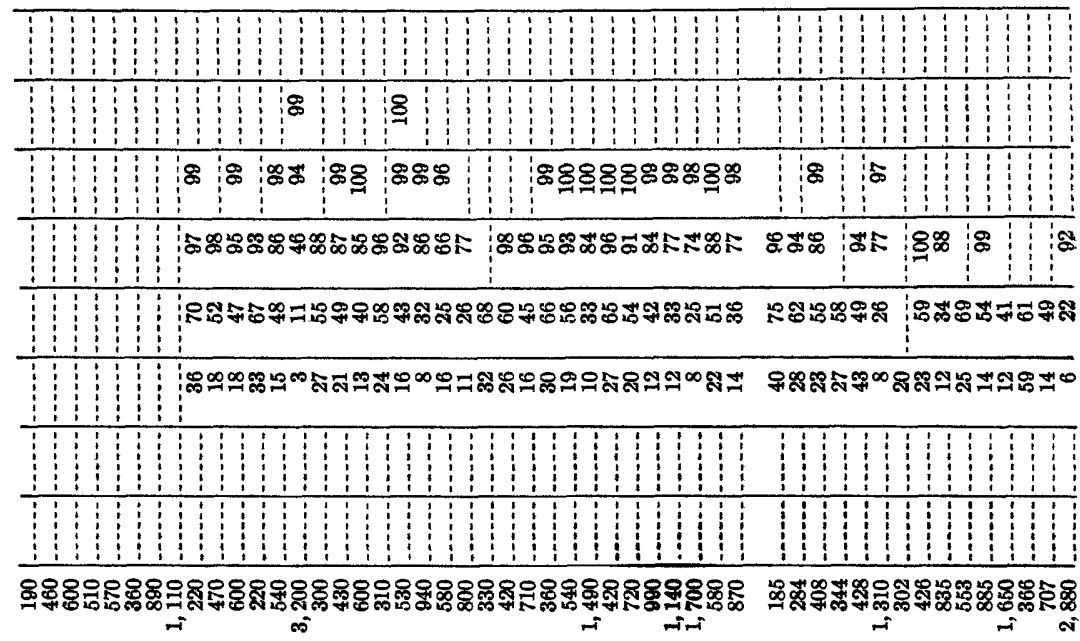

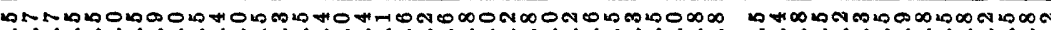

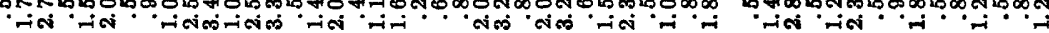

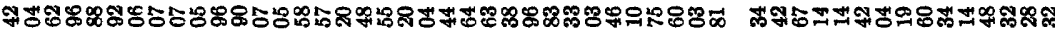

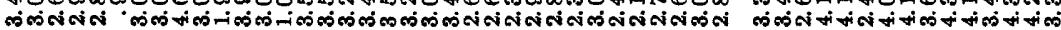

H-1 W W W

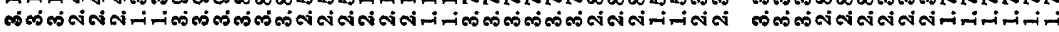

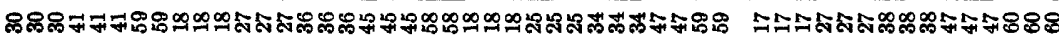

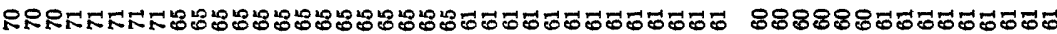

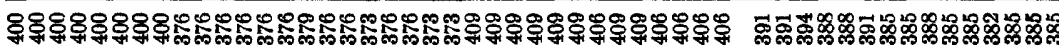

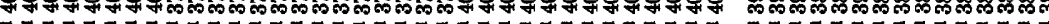

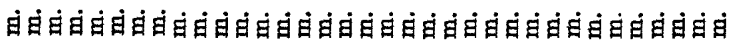

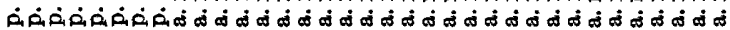

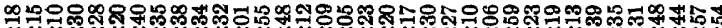

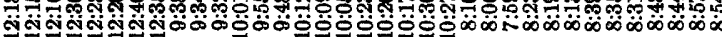

ดี่ย่

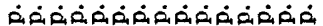

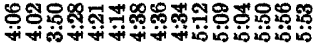

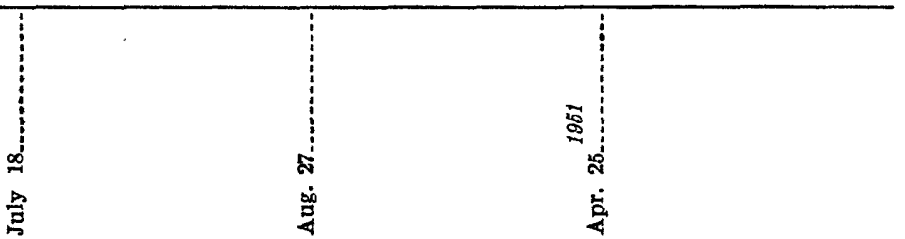


108 SEDIMENT TRANSPORTATION, MIDDLE LOUP RIVER, NEBR.

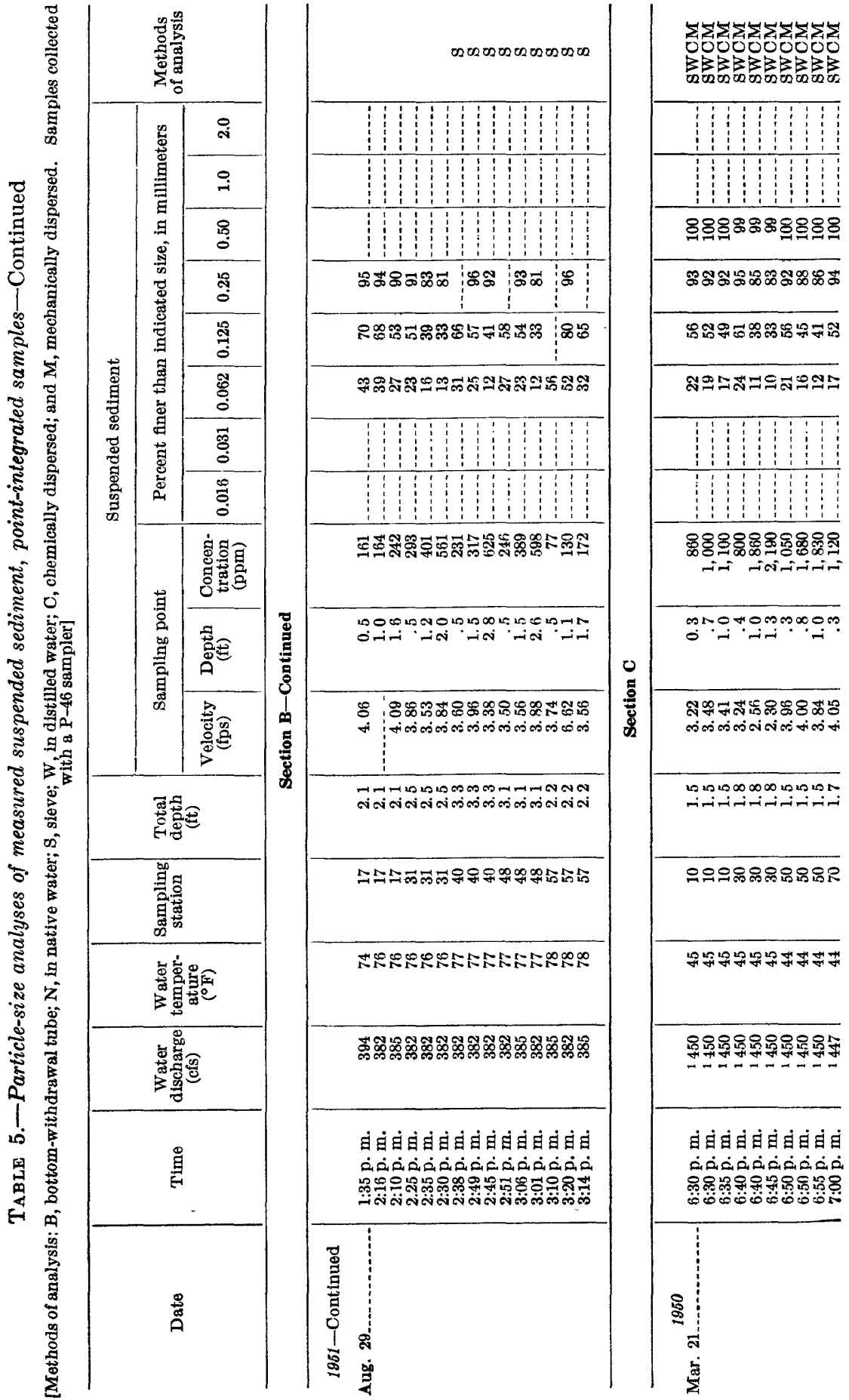




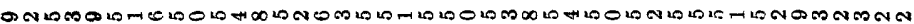

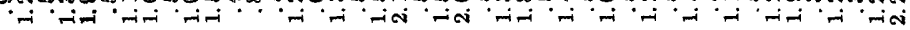

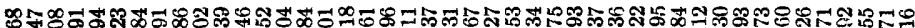

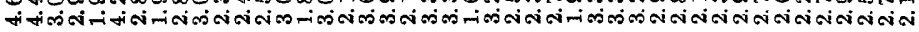

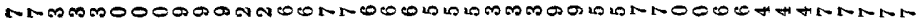

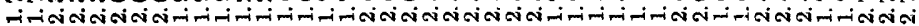

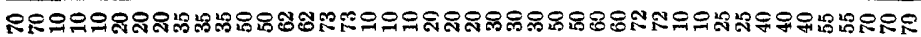

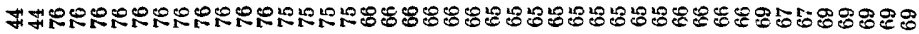

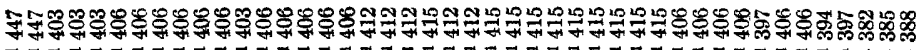

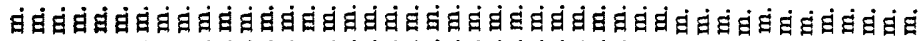
ف

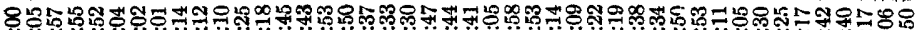

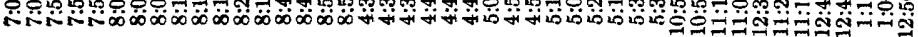

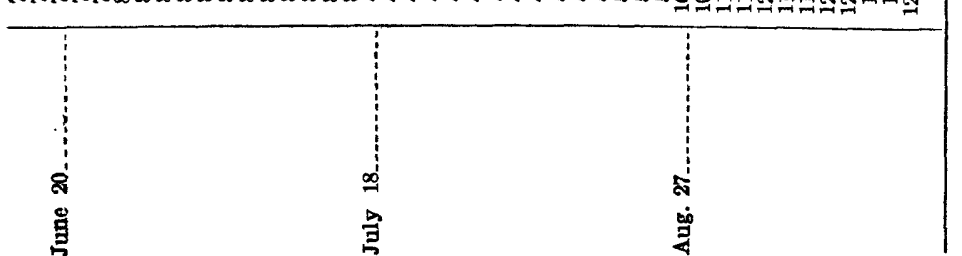




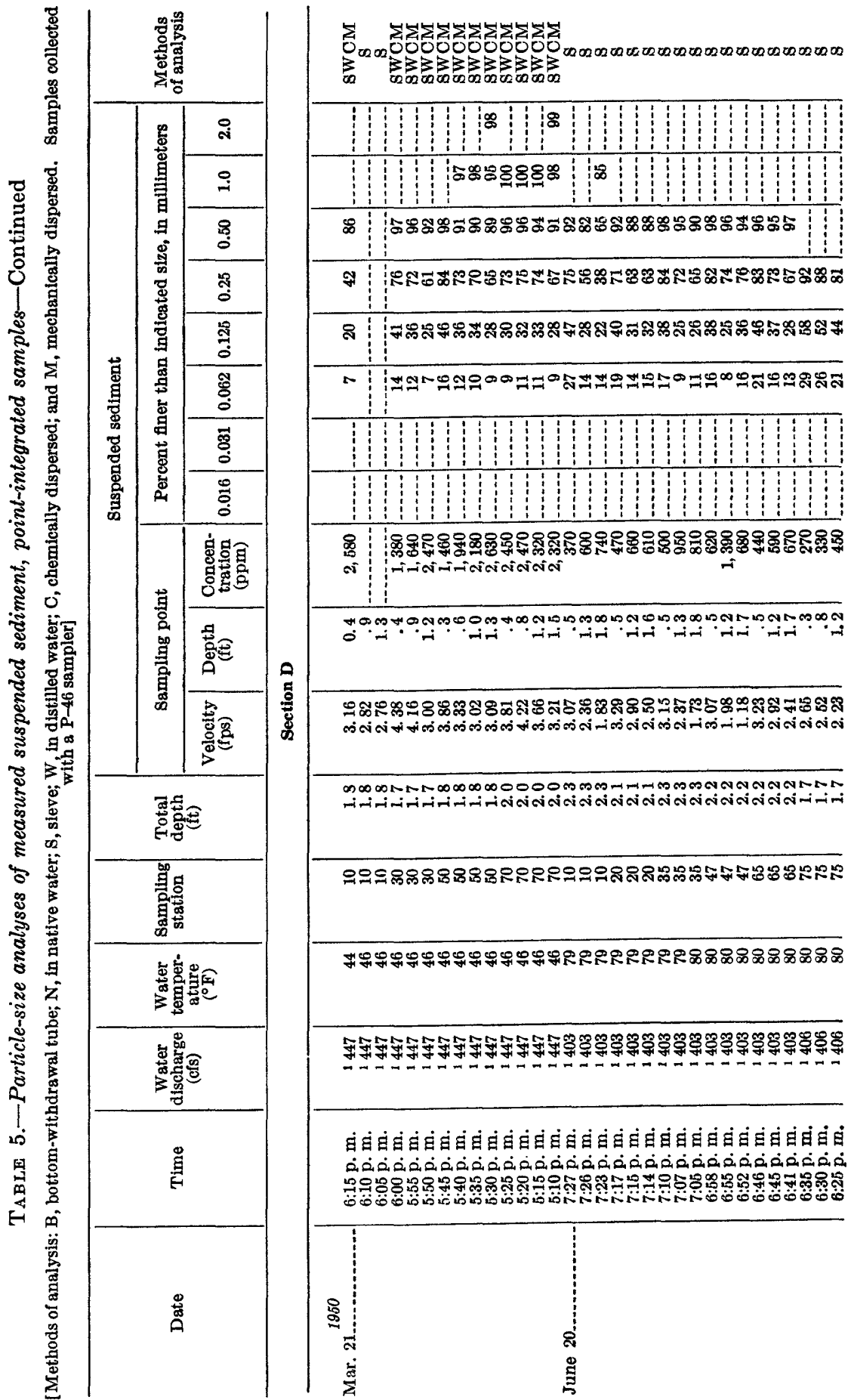




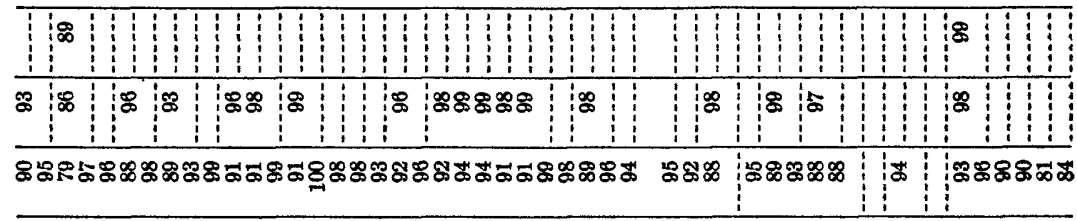

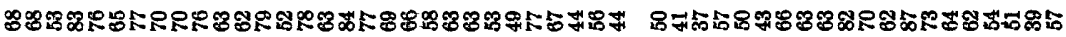

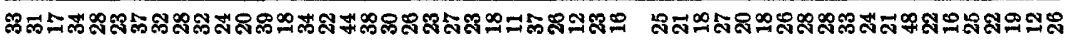

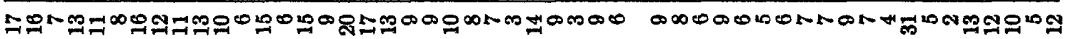

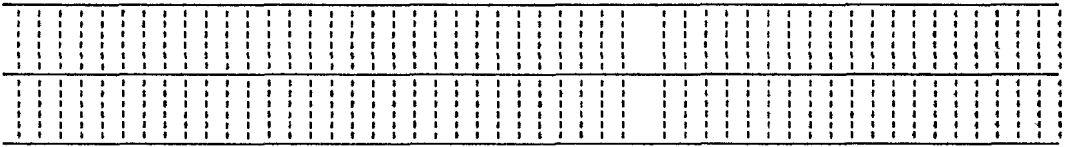

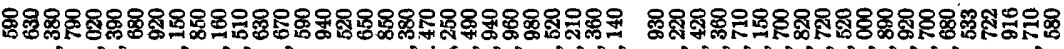

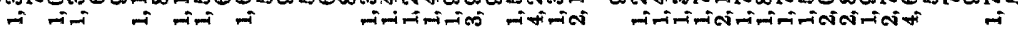

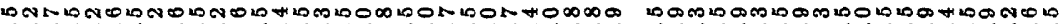

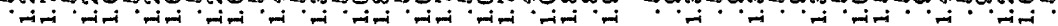

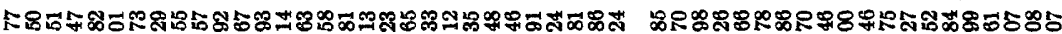

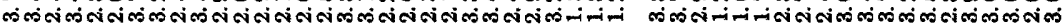

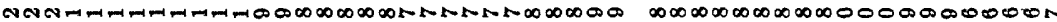
งं

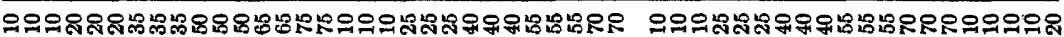

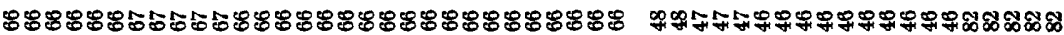

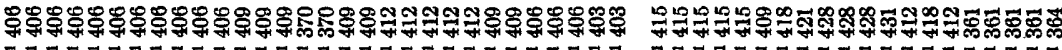

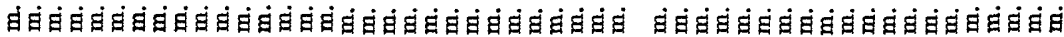

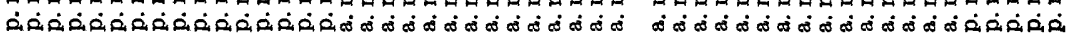

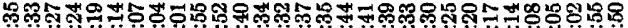
ஸें

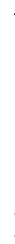

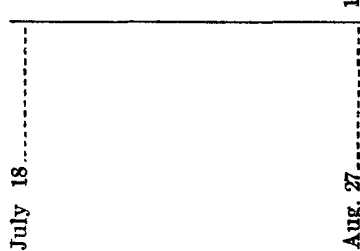

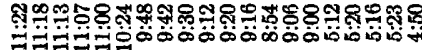




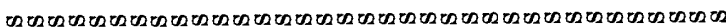

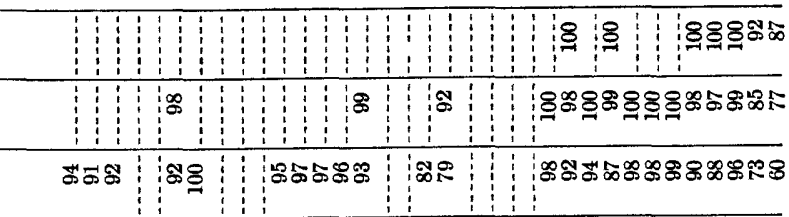

๒

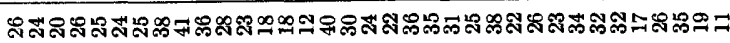

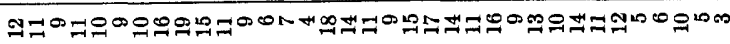

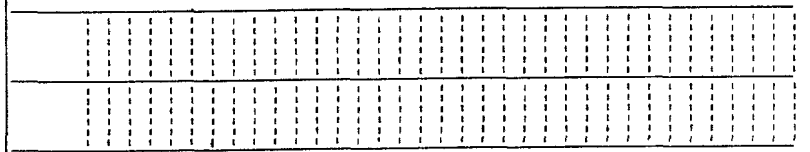

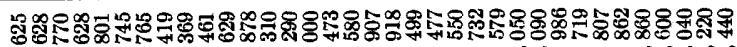
-imin in riminiciti

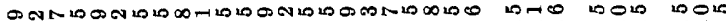

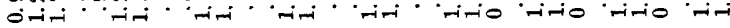

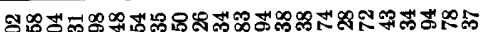

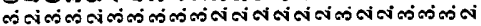

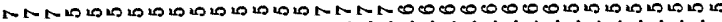

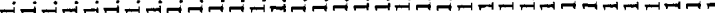

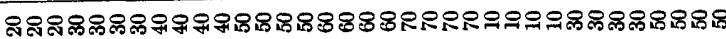

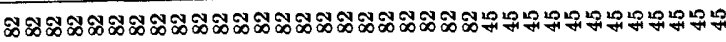
규ㅇㅠㅠ. -

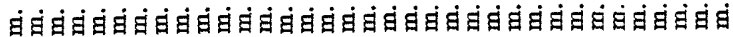

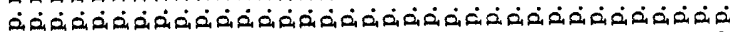

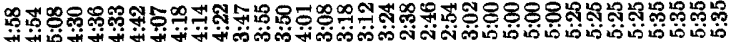




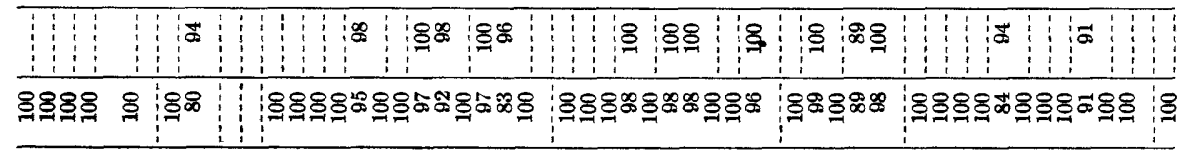

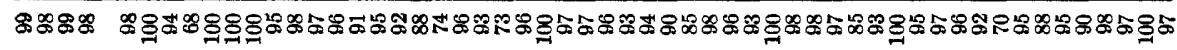

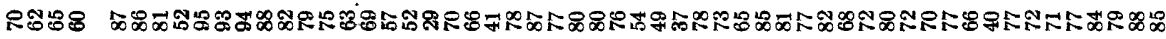

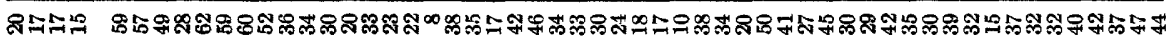

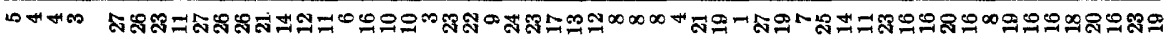

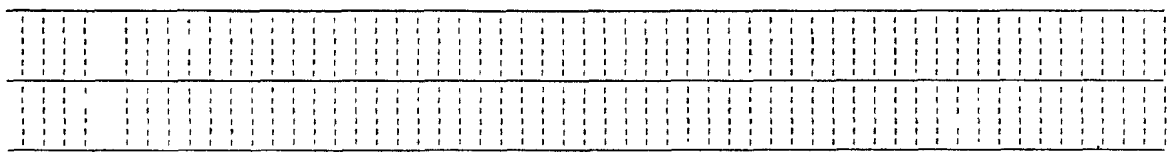

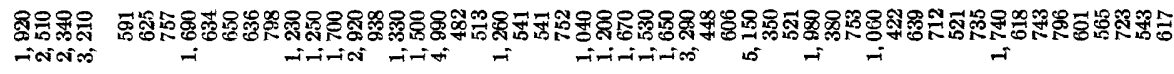

non

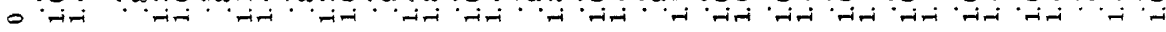

ஐ

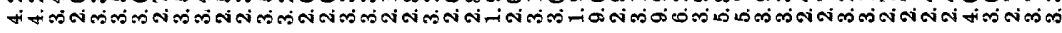

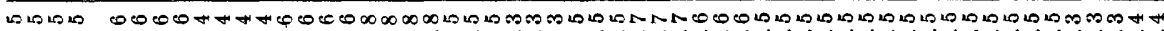

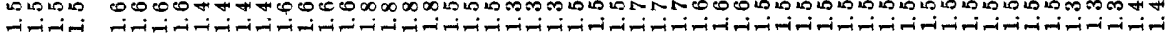

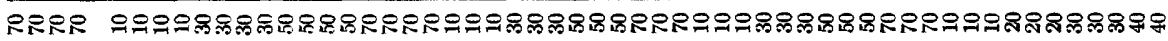

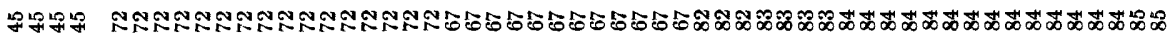

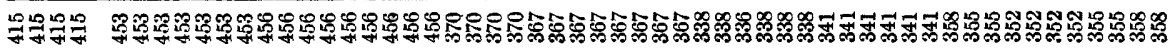

घंघं घं

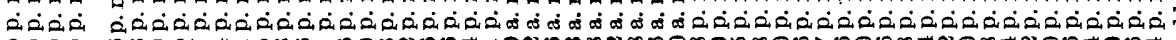

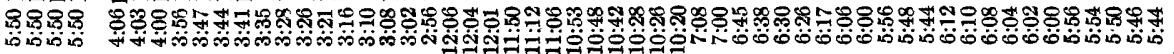

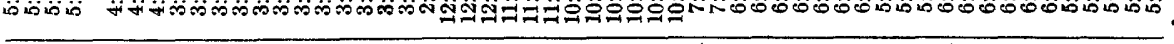

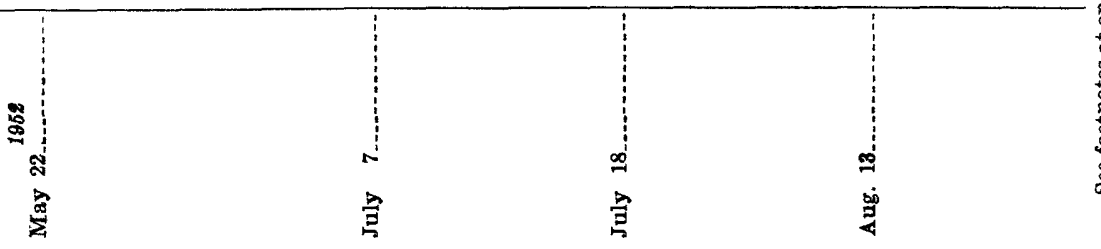


114 SEDIMENT TRANSPORTATION, MIDDLE LOUP RIVER, NEBR.

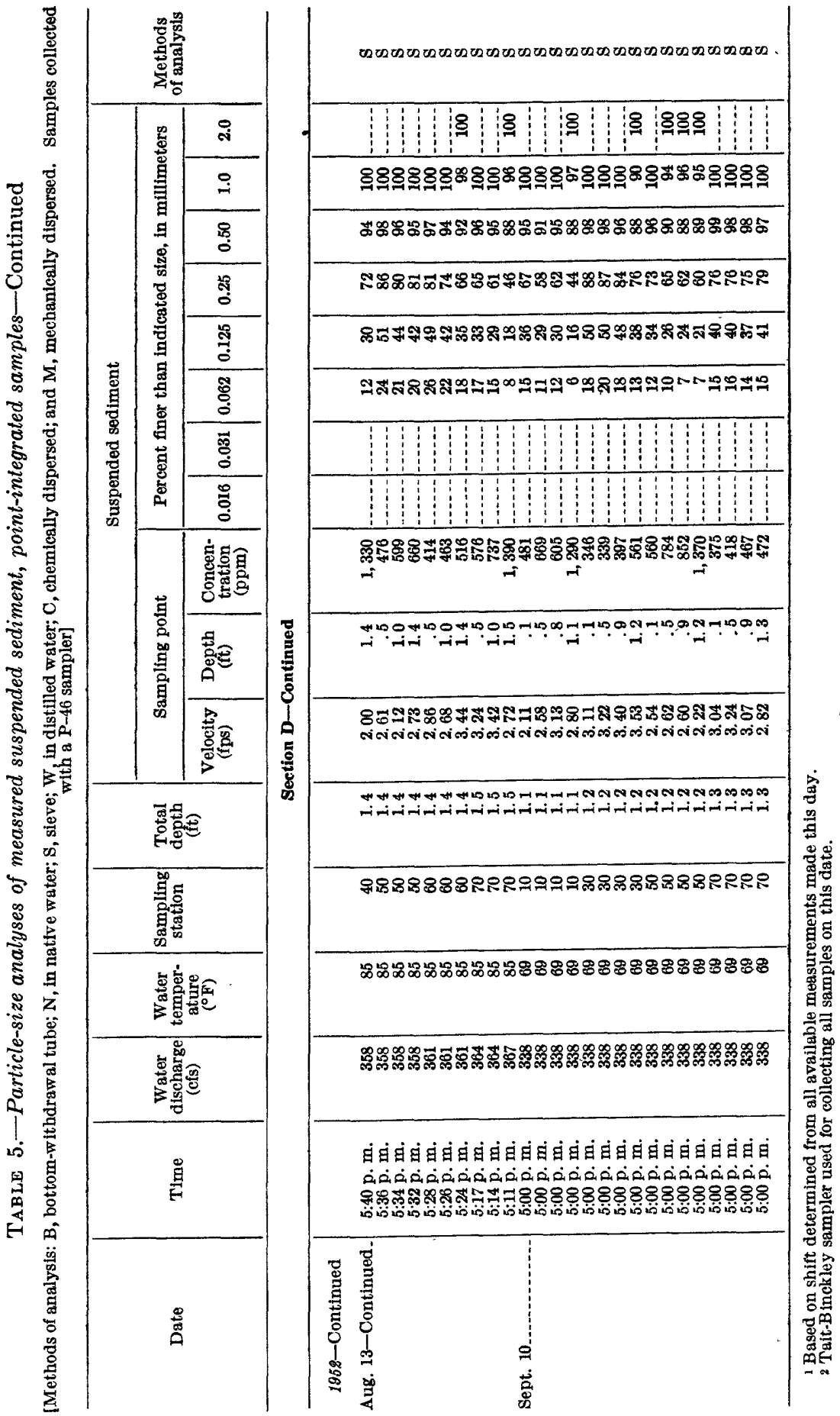


TABLE 6.-Monthly and annual summary of water and total sediment discharges, section $D$

\begin{tabular}{|c|c|c|c|c|c|c|c|c|}
\hline \multirow{3}{*}{ Month } & \multirow{3}{*}{$\begin{array}{c}\text { Water } \\
\text { dis- } \\
\text { charge } \\
\text { (cfs- } \\
\text { days) }\end{array}$} & \multirow{3}{*}{$\begin{array}{c}\text { Runoff } \\
\text { (acre- } \\
\text { feet) }\end{array}$} & \multicolumn{6}{|c|}{ Suspended sediment } \\
\hline & & & \multirow{2}{*}{$\begin{array}{c}\text { Load } \\
\text { (tons) }\end{array}$} & \multicolumn{3}{|c|}{ Daily load (tons) } & \multicolumn{2}{|c|}{$\begin{array}{c}\text { Concentration } \\
\text { (ppm) }\end{array}$} \\
\hline & & & & Mean & $\begin{array}{l}\text { Maxi- } \\
\text { mum }\end{array}$ & $\begin{array}{l}\text { Mini- } \\
\text { mum }\end{array}$ & $\underset{\text { mean }}{\text { Weighted }}$ & $\begin{array}{l}\text { Maxi- } \\
\text { mum } \\
\text { daily }\end{array}$ \\
\hline $\begin{array}{l}\text { Mar. } 22-31.1960 \\
\text { April } \\
\text { May } \\
\text { June. } \\
\text { July } \\
\text { August } \\
\text { September }\end{array}$ & $\begin{array}{r}4,527 \\
11,112 \\
11,774 \\
10,329 \\
11,014 \\
10,994 \\
10,701 \\
\end{array}$ & $\begin{array}{r}8,980 \\
22,040 \\
23,350 \\
20,490 \\
21,850 \\
21,810 \\
21,230 \\
\end{array}$ & $\begin{array}{l}28,970 \\
57,260 \\
47,600 \\
21,410 \\
24,830 \\
25,760 \\
26,520 \\
\end{array}$ & $\begin{array}{r}2,900 \\
1,910 \\
1,540 \\
710 \\
800 \\
830 \\
880 \\
\end{array}$ & $\begin{array}{r}4,000 \\
3,370 \\
3,270 \\
910 \\
1,580 \\
2,100 \\
1,430 \\
\end{array}$ & $\begin{array}{r}1,820 \\
1,310 \\
800 \\
490 \\
520 \\
540 \\
520 \\
\end{array}$ & $\begin{array}{r}2,370 \\
1,910 \\
1,500 \\
770 \\
830 \\
870 \\
920\end{array}$ & $\begin{array}{r}3,140 \\
3,290 \\
2,860 \\
930 \\
1,410 \\
1,400\end{array}$ \\
\hline Mar. 22 to Se & 70,451 & 139,800 & 232,400 & 1,200 & 4,000 & 490 & 1,220 & 3,290 \\
\hline $\begin{array}{l}\text { October........ } \\
\text { November..... } \\
\text { December...... }\end{array}$ & $\begin{array}{l}10,727 \\
11,507 \\
12,181\end{array}$ & $\begin{array}{l}21,280 \\
22,820 \\
24,160\end{array}$ & $\begin{array}{r}29,900 \\
48,490 \\
49,667\end{array}$ & $\begin{array}{r}960 \\
1,620 \\
1,600\end{array}$ & $\begin{array}{l}1,410 \\
2,460 \\
3,360\end{array}$ & $\begin{array}{r}690 \\
730 \\
57\end{array}$ & $\begin{array}{l}1,030 \\
1,560 \\
1,510\end{array}$ & $\begin{array}{l}1,660 \\
2,240 \\
3,110\end{array}$ \\
\hline $\begin{array}{l}\text { January } 1961 \\
\text { February } \\
\text { March } \\
\text { April } \\
\text { May } \\
\text { June...... }\end{array}$ & $\begin{array}{l}11,499 \\
12,095 \\
11,696 \\
10,006 \\
12,655 \\
12,202 \\
11,777 \\
11,365 \\
11,957\end{array}$ & $\begin{array}{l}22,810 \\
23,990 \\
23,200 \\
19,850 \\
25,100 \\
24,200 \\
23,360 \\
22,540 \\
23,720\end{array}$ & $\begin{array}{l}60,460 \\
21,070 \\
48,560 \\
36,680 \\
39,830 \\
36,970 \\
29,390 \\
25,550 \\
42,630\end{array}$ & $\begin{array}{r}1,950 \\
750 \\
1,570 \\
1,220 \\
1,280 \\
1,230 \\
950 \\
820 \\
1,420\end{array}$ & $\begin{array}{l}1,970 \\
2,130 \\
1,610 \\
1,970 \\
2,340 \\
2,120 \\
1,080 \\
3,000\end{array}$ & $\begin{array}{r}79 \\
980 \\
760 \\
870 \\
890 \\
650 \\
640 \\
940\end{array}$ & $\begin{array}{r}1,950 \\
650 \\
1,540 \\
1,360 \\
1,170 \\
1,120 \\
920 \\
830 \\
1,320\end{array}$ & $\begin{array}{l}1,770 \\
2,020 \\
1,830 \\
1,540 \\
1,850 \\
1,890 \\
1,010 \\
2,100\end{array}$ \\
\hline Water year 1 & 139,667 & 277,000 & 469,187 & 1,290 & 3,360 & - & 1,240 & 3,110 \\
\hline $\begin{array}{l}\text { October } \\
\text { November........... } \\
\text { December...... }\end{array}$ & $\begin{array}{l}12,040 \\
11,560 \\
12,013\end{array}$ & $\begin{array}{l}23,880 \\
22,930 \\
23,830\end{array}$ & $\begin{array}{l}48,580 \\
52,100 \\
30,314\end{array}$ & $\begin{array}{r}1,570 \\
1,740 \\
978\end{array}$ & $\begin{array}{l}2,140 \\
2,350 \\
2,200\end{array}$ & $\begin{array}{r}1,010 \\
1,340 \\
125\end{array}$ & $\begin{array}{r}1,490 \\
1,670 \\
934\end{array}$ & $\begin{array}{l}1,910 \\
2,280 \\
2,140\end{array}$ \\
\hline $\begin{array}{l}\text { January } 1952 \\
\text { February } \\
\text { March } \\
\text { April } \\
\text { May } \\
\text { June } \\
\text { July } \\
\text { August } \\
\text { September }\end{array}$ & $\begin{array}{l}11,782 \\
11,730 \\
13,541 \\
12,988 \\
12,671 \\
10,662 \\
10,834 \\
11,287 \\
10,305\end{array}$ & $\begin{array}{l}23,370 \\
23,270 \\
26,860 \\
25,760 \\
25,130 \\
21,150 \\
21,490 \\
22,390 \\
20,440\end{array}$ & $\begin{array}{r}8,835 \\
65,900 \\
66,406 \\
58,010 \\
65,590 \\
35,505 \\
26,929 \\
26,559 \\
27,923\end{array}$ & $\begin{array}{r}285 \\
2,270 \\
2,142 \\
1,930 \\
2,120 \\
1,180 \\
869 \\
857 \\
\mathbf{9 3 1}\end{array}$ & $\begin{array}{r}582 \\
3,860 \\
5,160 \\
3,370 \\
3,420 \\
2,330 \\
2,020 \\
1,200 \\
1,520\end{array}$ & $\begin{array}{r}21 \\
1,030 \\
850 \\
1,110 \\
1,010 \\
731 \\
556 \\
512 \\
717\end{array}$ & $\begin{array}{r}278 \\
2,080 \\
1,820 \\
1,650 \\
1,920 \\
1,230 \\
921 \\
872 \\
1,000\end{array}$ & $\begin{array}{r}501 \\
3,800 \\
3,300 \\
2,890 \\
3,420 \\
2,350 \\
2,040 \\
1,210 \\
1,530\end{array}$ \\
\hline Water year 1951-52. & 141,413 & 280,500 & 512,651 & 1,400 & 5,160 & 21 & 1,340 & 3,800 \\
\hline
\end{tabular}


116 SEDIMENT TRANSPORTATION, MIDDLE LOUP RIVER, NEBR.

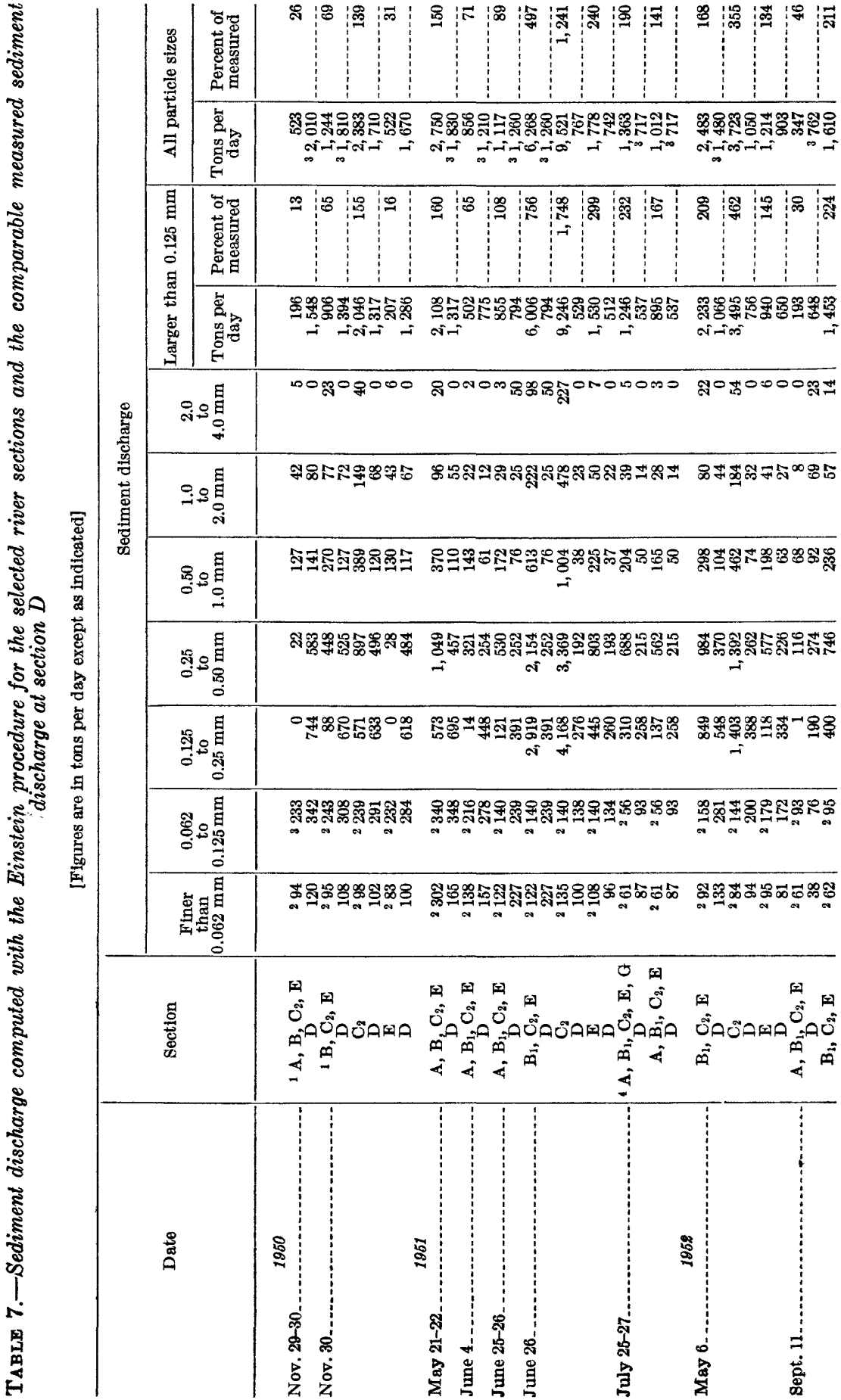




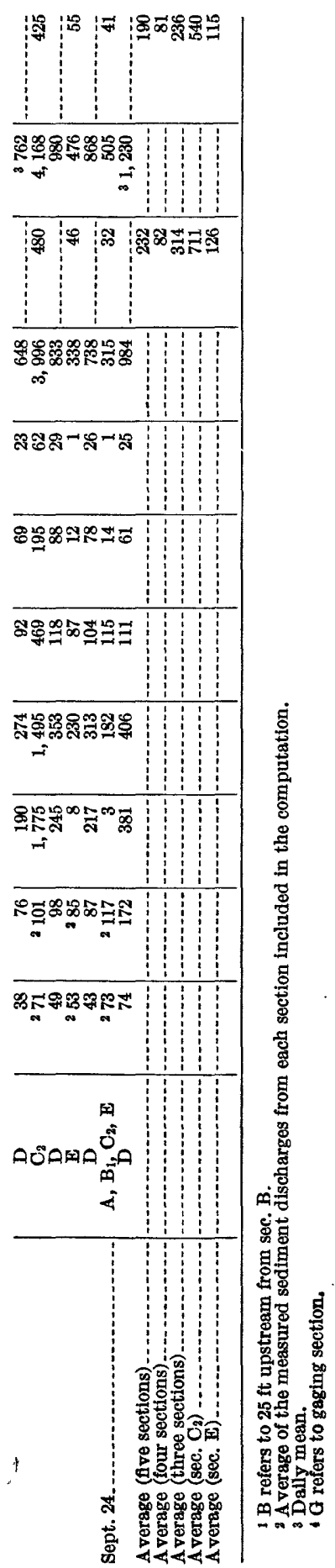




\section{SEDIMENT TRANSPORTATION, MIDDLE LOUP RIVER, NEBR.}

TABLE 8.-Sediment discharge computed with the modified Einstein procedure for the selected river sections and the comparable measured sediment discharge at section $D$

\begin{tabular}{|c|c|c|c|c|c|c|c|c|c|c|}
\hline \multirow[b]{2}{*}{ Date } & \multirow[b]{2}{*}{ Section } & \multicolumn{8}{|c|}{ Sediment discharge, in tons per day } & \multirow{2}{*}{$\begin{array}{l}\text { Percentage } \\
\text { of measured } \\
\text { sediment } \\
\text { discharge } \\
\text { at section D }\end{array}$} \\
\hline & & $\begin{array}{l}\text { Finer } \\
\text { than } \\
0.062 \\
\mathrm{~mm}\end{array}$ & $\begin{array}{c}0.062 \\
\text { to } \\
0.125 \\
\mathrm{~mm}\end{array}$ & $\begin{array}{c}0.125 \\
\text { to } \\
0.25 \\
\mathrm{~mm}\end{array}$ & $\begin{array}{c}0.25 \\
\text { to } \\
0.50 \\
\mathrm{~mm}\end{array}$ & $\begin{array}{c}0.50 \\
\text { to } \\
1.00 \\
\mathrm{~mm}\end{array}$ & $\begin{array}{c}1.00 \\
\text { to } \\
2.00 \\
\mathrm{~mm}\end{array}$ & $\begin{array}{c}2.00 \\
\text { to } \\
4.00 \\
\mathrm{~mm}\end{array}$ & Total & \\
\hline Ang. 25. 1949 & $\begin{array}{l}\mathrm{A} \\
\mathbf{D}\end{array}$ & $\begin{array}{l}51 \\
52\end{array}$ & $\begin{array}{l}75 \\
67\end{array}$ & $\begin{array}{l}186 \\
373\end{array}$ & $\begin{array}{l}142 \\
179\end{array}$ & $\begin{array}{l}45 \\
75\end{array}$ & $\begin{array}{l}4 \\
0\end{array}$ & $\begin{array}{l}0 \\
0\end{array}$ & $\begin{array}{l}503 \\
746\end{array}$ & 67 \\
\hline \multirow[t]{4}{*}{ Mar. 1} & & $\begin{array}{l}372 \\
412\end{array}$ & 645 & 1,361 & 733 & 240 & 55 & 13 & 3,419 & 116 \\
\hline & $\mathrm{B}$ & $\begin{array}{l}412 \\
427\end{array}$ & 512 & $\begin{array}{l}1,088 \\
1,199\end{array}$ & $\begin{array}{l}070 \\
562\end{array}$ & $\begin{array}{l}176 \\
212\end{array}$ & $\begin{array}{l}88 \\
57\end{array}$ & 14 & 2,983 & 101 \\
\hline & $\underset{\mathbf{E}}{\mathbf{D}}$ & $\begin{array}{l}412 \\
407\end{array}$ & $\begin{array}{l}471 \\
555\end{array}$ & $\begin{array}{l}1,088 \\
1,481\end{array}$ & $\begin{array}{l}676 \\
832\end{array}$ & $\begin{array}{l}176 \\
295\end{array}$ & $\begin{array}{l}88 \\
62\end{array}$ & $\begin{array}{l}29 \\
10\end{array}$ & $\begin{array}{l}2,940 \\
3,642\end{array}$ & 124 \\
\hline & D & 410 & 469 & 1,084 & 674 & 176 & 88 & 29 & & \\
\hline Mar. 2 & $\stackrel{\mathrm{A}}{\mathrm{D}}$ & $\begin{array}{l}247 \\
214\end{array}$ & $\begin{array}{l}520 \\
549\end{array}$ & $\begin{array}{l}1,164 \\
1,159\end{array}$ & $\begin{array}{l}564 \\
884\end{array}$ & $\begin{array}{l}167 \\
183\end{array}$ & $\begin{array}{l}26 \\
61\end{array}$ & $\begin{array}{l}3 \\
0\end{array}$ & 3, & 88 \\
\hline & $\mathbf{B}$ & 264 & 669 & 1,573 & 689 & 201 & 37 & 5 & & 114 \\
\hline & $\underset{\mathbf{E}}{\mathbf{D}}$ & $\begin{array}{l}211 \\
282\end{array}$ & $\begin{array}{l}542 \\
543\end{array}$ & $\begin{array}{l}1,144 \\
1,011\end{array}$ & $\begin{array}{l}873 \\
585\end{array}$ & $\begin{array}{l}180 \\
291\end{array}$ & $\begin{array}{l}60 \\
53\end{array}$ & $\begin{array}{l}0 \\
9\end{array}$ & $\begin{array}{l}3, \\
2,\end{array}$ & 92 \\
\hline Apr & $\mathbf{D}$ & 210 & 540 & 1,140 & 870 & 180 & 60 & 0 & & \\
\hline Apr & $\stackrel{\mathrm{A}}{\mathrm{D}}$ & $\begin{array}{l}125 \\
151\end{array}$ & $\begin{array}{l}402 \\
359\end{array}$ & $\begin{array}{l}945 \\
775\end{array}$ & $\begin{array}{l}549 \\
510\end{array}$ & $\begin{array}{r}197 \\
95\end{array}$ & $\begin{array}{r}33 \\
0\end{array}$ & $\begin{array}{l}4 \\
0\end{array}$ & $\begin{array}{l}2,255 \\
1,890\end{array}$ & 11 \\
\hline & $\underset{D}{B}$ & 139 & 417 & 989 & 481 & 158 & 29 & 3 & & 127 \\
\hline & E & 143 & 366 & 762 & $\begin{array}{l}472 \\
431\end{array}$ & 155 & $\begin{array}{l}10 \\
22\end{array}$ & 2 & & 109 \\
\hline Apr. 2 & D & 138 & 329 & 709 & 467 & 87 & 0 & 0 & & \\
\hline Apr. 2 & $\stackrel{\mathrm{A}}{\mathrm{D}}$ & $\begin{array}{l}155 \\
155\end{array}$ & $\begin{array}{l}374 \\
398\end{array}$ & $\begin{array}{l}989 \\
994\end{array}$ & $\begin{array}{l}616 \\
508\end{array}$ & $\begin{array}{l}191 \\
111\end{array}$ & $\begin{array}{l}22 \\
44\end{array}$ & $\begin{array}{l}2 \\
0\end{array}$ & $\begin{array}{l}2,349 \\
2,210\end{array}$ & 106 \\
\hline & $\mathbf{B}$ & 176 & 424 & 1,255 & 603 & 215 & 45 & 8 & & 114 \\
\hline & $\underset{\mathbf{E}}{\mathbf{D}}$ & $\begin{array}{l}168 \\
142\end{array}$ & $\begin{array}{l}432 \\
362\end{array}$ & $\begin{array}{r}1,080 \\
979\end{array}$ & $\begin{array}{l}552 \\
634\end{array}$ & $\begin{array}{l}120 \\
245\end{array}$ & $\begin{array}{l}48 \\
44\end{array}$ & $\begin{array}{l}0 \\
6\end{array}$ & & 145 \\
\hline & $\overline{\mathrm{D}}$ & 116 & 299 & 747 & 382 & 83 & 33 & 0 & & \\
\hline May 9... & $\stackrel{\mathbf{A}}{\mathbf{D}}$ & $\begin{array}{l}235 \\
144\end{array}$ & $\begin{array}{l}252 \\
416\end{array}$ & $\begin{array}{r}1,038 \\
624\end{array}$ & $\begin{array}{l}615 \\
272\end{array}$ & $\begin{array}{l}204 \\
112\end{array}$ & $\begin{array}{l}44 \\
32\end{array}$ & $\begin{array}{r}10 \\
0\end{array}$ & & 150 \\
\hline & $\mathbf{E}$ & 154 & 327 & 507 & 339 & 130 & 16 & 1 & & 105 \\
\hline & D & 127 & 366 & 550 & 240 & 99 & 2 & 0 & 1 , & \\
\hline May 23. & $\mathbf{A}$ & $\begin{array}{l}81 \\
92\end{array}$ & 134 & $\begin{array}{l}349 \\
338\end{array}$ & 299 & 110 & 13 & 1 & & 129 \\
\hline & $\mathbf{E}$ & 130 & 121 & 36 & 3 & 13 & 2 & 2 & 1, & 148 \\
\hline & D & 87 & 152 & 318 & 14 & 2 & 0 & 0 & & \\
\hline June 6... & $\mathbf{E}$ & 54 & 118 & 291 & 236 & 104 & 13 & 1 & 817 & 163 \\
\hline June $20 \ldots$ & $\mathbf{A}$ & $\begin{array}{r}50 \\
108\end{array}$ & $\begin{array}{r}90 \\
139\end{array}$ & $\begin{array}{l}186 \\
222\end{array}$ & $\begin{array}{l}140 \\
191\end{array}$ & $\begin{array}{l}25 \\
45\end{array}$ & $\begin{array}{r}10 \\
1\end{array}$ & $\begin{array}{l}0 \\
0\end{array}$ & $\begin{array}{l}501 \\
706\end{array}$ & 117 \\
\hline & $\bar{D}$ & 84 & 109 & 235 & 139 & 24 & 12 & 0 & 603 & \\
\hline & $\mathbf{B}$ & 90 & 162 & 383 & 253 & 95 & 13 & 1 & 997 & 111 \\
\hline & & 126 & 162 & 351 & 2 & 36 & 18 & 0 & & \\
\hline July $6 \ldots$ & $\mathbf{E}$ & 74 & 151 & 292 & 208 & 78 & 8 & 0 & 811 & 131 \\
\hline lg. 2 & $D$ & 62 & $\begin{array}{l}124 \\
274\end{array}$ & $\begin{array}{l}216 \\
441\end{array}$ & & 43 & 19 & 12 & & \\
\hline 8.20 & 3 & $\begin{array}{l}190 \\
135\end{array}$ & $\begin{array}{l}279 \\
218\end{array}$ & $\begin{array}{l}441 \\
420\end{array}$ & $\begin{array}{l}29 b \\
840\end{array}$ & $\begin{array}{r}115 \\
67\end{array}$ & 0 & 0 & $\begin{array}{l}1,357 \\
1,680\end{array}$ & \\
\hline & $\mathbf{E}$ & 156 & 216 & 322 & 21 & 79 & 7 & 0 & & 6 \\
\hline & $D$ & 124 & 201 & 388 & 775 & 62 & 0 & 0 & & \\
\hline Oct. 4. & A & 63 & 208 & 516 & 315 & 91 & 7 & 0 & 1,200 & 12 \\
\hline & D & 67 & 163 & $\begin{array}{l}383 \\
469\end{array}$ & 259 & $\begin{array}{l}57 \\
80\end{array}$ & 29 & 0 & $\begin{array}{r}958 \\
\end{array}$ & iij \\
\hline & D & $\begin{array}{l}69 \\
65\end{array}$ & $\begin{array}{l}195 \\
156\end{array}$ & $\begin{array}{l}409 \\
368\end{array}$ & $\begin{array}{l}236 \\
248\end{array}$ & $\begin{array}{l}80 \\
55\end{array}$ & 28 & 0 & $\begin{array}{r}1,055 \\
920\end{array}$ & 115 \\
\hline & $\mathrm{C}_{2}$ & 101 & 193 & 376 & 29 & 98 & 15 & 1 & 1,076 & 117 \\
\hline & $D$ & 64 & 157 & 36 & 2 & 55 & 28 & 0 & 9 & \\
\hline & $\mathbf{E}$ & $\begin{array}{l}60 \\
62\end{array}$ & $\begin{array}{l}144 \\
152\end{array}$ & $\begin{array}{l}335 \\
358\end{array}$ & $\begin{array}{l}19 \\
28\end{array}$ & $\begin{array}{l}70 \\
54\end{array}$ & $\begin{array}{r}6 \\
27\end{array}$ & 0 & & \\
\hline Nov. 8. & $\mathrm{D}$ & 103 & 321 & 963 & 431 & 128 & 19 & 2 & 1,9 & 124 \\
\hline & & 126 & 316 & 648 & 363 & 11 & 16 & 0 & & \\
\hline & $\mathrm{C}_{2}$ & 105 & 354 & 810 & 475 & 159 & 35 & 4 & 1,942 & 116 \\
\hline & & 133 & $\begin{array}{l}334 \\
345\end{array}$ & $\begin{array}{r}685 \\
\end{array}$ & $\begin{array}{l}384 \\
747\end{array}$ & 117 & 17 & 0 & $\begin{array}{l}1,670 \\
2,856\end{array}$ & 166 \\
\hline & $D$ & 138 & $\begin{array}{l}540 \\
344\end{array}$ & $\begin{array}{r}1,108 \\
705\end{array}$ & 396 & $\begin{array}{l}380 \\
120\end{array}$ & $\begin{array}{r}128 \\
17\end{array}$ & 0 & $\begin{array}{l}2,800 \\
1,720\end{array}$ & \\
\hline Nov. 30 & $1 \mathrm{~B}$ & 106 & 291 & 743 & 406 & 123 & 20 & 3 & 1,692 & 100 \\
\hline & $\mathrm{D}_{2}$ & 101 & 287 & 626 & 490 & 118 & 68 & 0 & $\begin{array}{l}1,690 \\
1,700\end{array}$ & 99 \\
\hline & $D^{2}$ & $\begin{array}{r}98 \\
102\end{array}$ & $\begin{array}{l}284 \\
291\end{array}$ & $\begin{array}{l}682 \\
633\end{array}$ & $\begin{array}{l}419 \\
496\end{array}$ & $\begin{array}{l}167 \\
120\end{array}$ & $\begin{array}{l}48 \\
68\end{array}$ & 0 & $\begin{array}{l}1,700 \\
1,710\end{array}$ & \\
\hline & & 83 & 284 & 8 & 47 & 176 & 30 & 4 & 1,896 & 114 \\
\hline & & 100 & & & 48 & 117 & 67 & 0 & 1,670 & \\
\hline
\end{tabular}

$125 \mathrm{ft}$ upstream from section $B$. 
TABLES OF BASIC DATA

TABLE 8.-Sediment discharge computed with the modified Einstein procedure for the selected river sections and the comparable measured sediment discharge at section $D$-Continued

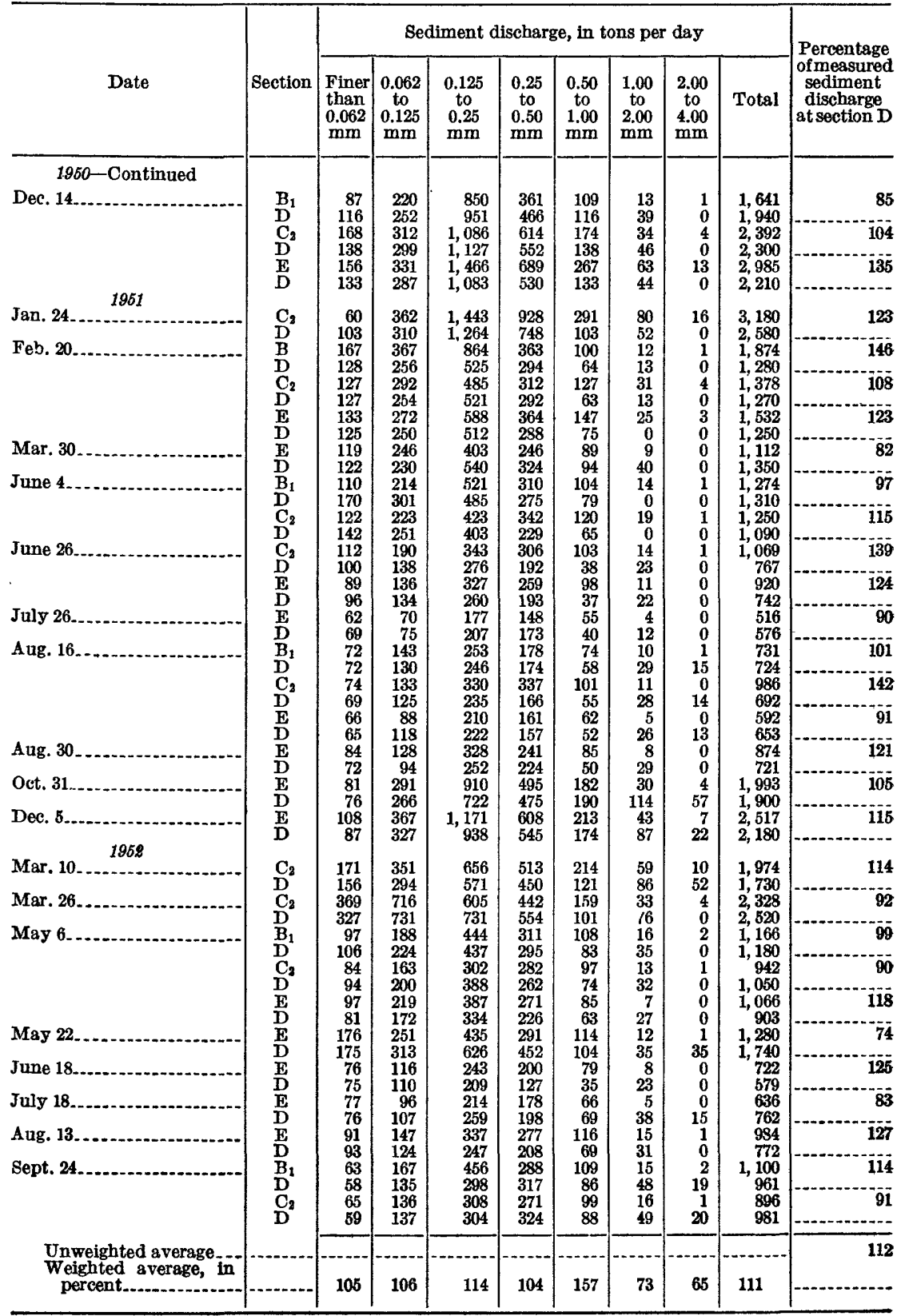


120 SEDIMENT TRANSPORTATION, MIDDLE LOUP RIVER, NEBR.

TABLE 9.-Sediment discharges computed with several formulas and data for comparison

\begin{tabular}{|c|c|c|c|c|c|c|c|c|c|c|}
\hline \multirow{3}{*}{ Date } & \multicolumn{6}{|c|}{ Sediment discharge, in tons per day } & \multirow{2}{*}{\multicolumn{4}{|c|}{$\begin{array}{l}\text { Ratio of mean concentration in } \\
\text { unsampled zone to that in } \\
\text { sampled zone }\end{array}$}} \\
\hline & \multicolumn{4}{|c|}{ Computed for section $\mathrm{E}$} & \multirow{2}{*}{$\begin{array}{l}\text { Un- } \\
\text { meas- } \\
\text { at sec- } \\
\text { tion E }\end{array}$} & \multirow{2}{*}{$\begin{array}{l}\text { Meas- } \\
\text { ured } \\
\text { at sec- } \\
\text { tion D }\end{array}$} & & & & \\
\hline & Straub & linske & $\begin{array}{l}\text { Schok- } \\
\text { litsch }\end{array}$ & $\begin{array}{l}\text { Meyer- } \\
\text { Peter } \\
\text { and } \\
\text { Müller }\end{array}$ & & & Straub & $\begin{array}{c}\mathrm{Ka}- \\
\text { linske }\end{array}$ & $\begin{array}{l}\text { Schok- } \\
\text { litsch }\end{array}$ & $\begin{array}{l}\text { Meyer- } \\
\text { Peter } \\
\text { and } \\
\text { Muller }\end{array}$ \\
\hline $\begin{array}{l}1949 \\
\text { Aug. } 17 \\
\text { Sept. } 13 \\
\end{array}$ & $\begin{array}{l}2,722 \\
2,510 \\
4,324\end{array}$ & $\begin{array}{l}330 \\
302 \\
360\end{array}$ & $\begin{array}{l}411 \\
360 \\
590\end{array}$ & $\begin{array}{l}149 \\
141 \\
192\end{array}$ & $\begin{array}{l}784 \\
443 \\
493\end{array}$ & $\begin{array}{r}1,190 \\
691 \\
842\end{array}$ & & $\begin{array}{l}6.33 \\
\text { 3. } 37 \\
2.66\end{array}$ & $\begin{array}{l}5.38 \\
2.39\end{array}$ & $\begin{array}{l}8.45 \\
6.08 \\
4.75\end{array}$ \\
\hline $\begin{array}{ll} & 1950 \\
\text { Mar. } 1 & 1 . \\
& 21 \\
\text { A pr. } 12 & \\
& 25\end{array}$ & $\begin{array}{l}1,013 \\
3,810 \\
3,742 \\
1,719\end{array}$ & $\begin{array}{l}206 \\
296 \\
301 \\
230\end{array}$ & $\begin{array}{l}317 \\
689 \\
534 \\
333\end{array}$ & $\begin{array}{l}404 \\
462 \\
279 \\
350\end{array}$ & $\begin{array}{r}1,370 \\
1,690 \\
720 \\
791\end{array}$ & $\begin{array}{l}2,930 \\
3,000 \\
1,730 \\
1,660\end{array}$ & & $\begin{array}{l}\text { 3. } 77 \\
\text { 4. } 94 \\
2.66 \\
3.48\end{array}$ & $\begin{array}{l}3.50 \\
3.86 \\
1.74 \\
3.02\end{array}$ & $\begin{array}{l}3.29 \\
4.47 \\
2.74 \\
2.95\end{array}$ \\
\hline $\begin{array}{l}\text { June } 6 \\
\text { Dec. } 14\end{array}$ & $\begin{array}{l}3,677 \\
3,288\end{array}$ & $\begin{array}{l}331 \\
278\end{array}$ & $\begin{array}{l}507 \\
572\end{array}$ & $\begin{array}{l}233 \\
488\end{array}$ & $\begin{array}{l}210 \\
800\end{array}$ & $\begin{array}{r}501 \\
2,210\end{array}$ & & 2.68 & 1.73 & 2.00 \\
\hline \begin{tabular}{l}
\multicolumn{1}{c}{1951} \\
Feb. 20 \\
Mar. 30 \\
July 26 \\
Oct. 31 \\
Dec. 5
\end{tabular} & $\begin{array}{l}5,583 \\
2,846 \\
4,129 \\
3,229 \\
1,962\end{array}$ & $\begin{array}{l}330 \\
317 \\
342 \\
312 \\
\mathbf{2 3 6}\end{array}$ & $\begin{array}{l}613 \\
449 \\
400 \\
525 \\
413\end{array}$ & $\begin{array}{l}337 \\
192 \\
130 \\
346 \\
359\end{array}$ & $\begin{array}{r}512 \\
802 \\
342 \\
1,015 \\
1,100\end{array}$ & $\begin{array}{r}\mathbf{1}, \mathbf{2 5 0} \\
\mathbf{1}, \mathbf{3 5 0} \\
\mathbf{5 7 6} \\
\mathbf{1}, 900 \\
\mathbf{2}, \mathbf{1 8 0}\end{array}$ & (n) & $\begin{array}{r}1.91 \\
4.85 \\
-4.18 \\
4.33\end{array}$ & $\begin{array}{l}3.80 \\
3.22 \\
3.65\end{array}$ & $\begin{array}{l}1.88 \\
5.84 \\
5.53 \\
4.02 \\
3.86\end{array}$ \\
\hline $\begin{array}{l}\text { July } 18 \\
\text { Jug. } 13 \\
\text { Sept. } 24 \\
\end{array}$ & $\begin{array}{l}4,831 \\
4,376 \\
3,694\end{array}$ & $\begin{array}{l}337 \\
318 \\
318\end{array}$ & $\begin{array}{l}468 \\
463 \\
441\end{array}$ & $\begin{array}{l}138 \\
231 \\
189\end{array}$ & $\begin{array}{l}492 \\
426 \\
549\end{array}$ & $\begin{array}{r}762 \\
772 \\
1,020\end{array}$ & 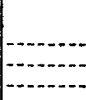 & $\begin{array}{l}3.50 \\
2.36 \\
3.13\end{array}$ & $\begin{array}{r}1.39 \\
\hdashline 2.00\end{array}$ & $\begin{array}{l}6.70 \\
3.45 \\
4.33\end{array}$ \\
\hline
\end{tabular}




\section{INDEX}

A

Acknowledgments

Albertson, M. L., quoted.

B

Basic data tables of

6-41 $82-120$

Bed load, definition. . . size analysis, section A................... 27

Bed-load discharge........................... 42

Kalinske equation for computing. ........ 62-65

Bed-material discharge, definition............ 10

Einstein method for computing........... 42-61

Bed-material load, definition.................. 8

Bed-material samples, section C........... 15 section $\mathrm{D}$

23,104

Benedict, P. C., quoted

$11-12,23$

Bibliography. 78-79

o

Conclusions

D

Definitions

bed load

bed-material discharge.

bed-material load

depth-integrated sediment

effective area.

effective width.

fluvial sediment ...........................

gaging section

geometric mean size.......................

mean concentration.

measured suspended sediment .............

measured suspended-sediment discharge..

movement of sediment, mode of

point-integrated sediment sample..........

saltation load

sampling zone

sediment discharge, measured.

total.

unmeasured.

sediment load

surface creep.

suspended load

suspended sediment.

wash load.

water discharge

epth, stream, section $A$.

section $B$

section $\mathrm{B}_{1}$

section $\mathbf{C}_{1}$

section $\mathrm{C}_{2}$

section $\mathbf{E}$

Depth-integrated samples, section D

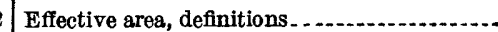

Effective width, definitions.....................

Einstein, H. A., definition of bed load by.... equation 9 .

equation 33

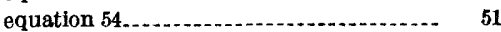

equation 63 , modification of.............. 51

Einstein procedure, bed-material-discharge computation. .................. 42-61, 75 modified, for total-sediment computation. 46

Equation, Du Boys. . ........................... 61

Einstein's No. 9...................... 46

Einstein's No. 29........................ 70

Einstein's No. 33 ......................... 47

Einstein's No. 54......................... 51

Einstein's No. 63........................ 51

Kalinske's No, 108. . . . . . . . . . . ........ 62,77

Meyer-Peter and Müller, bed-load discharge ............................... 67-68

Schoklitsch, bed load....................... 66,77

Straub_................................. 61-62

a, shear velocity ......................... 47

b, shear velocity............................. 47

c, total suspended-sediment discharge _... 47-49

$\mathrm{d}$, total suspended-sediment discharge .... $\quad 47$,

$48,49,68$

e, total suspended-sediment discharge .... 49, 58

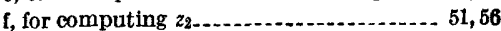

$\mathrm{g}$, for computing $z_{3} \ldots \ldots \ldots \ldots \ldots$

$\mathrm{h}$, for computing $z_{3} \ldots \ldots \ldots \ldots \ldots$

$\mathrm{i}$, flow and bed-load intensities........... 52

$\mathrm{j}$, fiow and bed-load intensities........... 52

$\mathrm{k}$, sediment discharge in $\mathrm{lb}$ per $\mathrm{ft} . \ldots . . . .55$

$m, z_{2} \ldots \ldots$

Equipment. (See also Turbulence flume.)

depth-integrated sampler............... 8, 15-19

piston-type samplers....................... 68

point-integrating samplers.................. 9

suspended-sediment sampler.............. 8

temperature recorder, air and water...... $\quad 15$

water-stage recorder, permanent.......... $\quad 15$

Exponent $z$, modified formulas for ............ 49-51

$\mathbf{F}$

Fluvial sediment, definition.....................

Formulas, modified, flow and bed-load transport intensities (see also Equation) 
Page

Gaging section, definition

Geometric mean size, deflnition

\section{I}

Introduction

\section{K}

Kalinske equation, bed-load discharge of unigranular material. $62-65,72$

\section{$\mathbf{M}$}

Matejka, D. Q., quoted $11-12,23$

Mean concentration, definition. $97-68,78$

Meyer-Peter and Míller equation $67-68,78$

Middle Loup River, basic information on....

$\mathbf{N}$

Niobrara River, variation of $k$ at

\section{$\mathbf{P}$}

Personnel

Point-integrated sediment sample, definition. section $B$

section $B_{1} \ldots \ldots \ldots$

section $\mathrm{C}$

$\mathbf{R}$

Relief, topographic

River sections, selected

gaging sections.

section A

section $\mathrm{B}$

section $\mathbf{B}_{1}$

section $\mathrm{C}$

section $\mathbf{C}_{1}$

section $\mathbf{C}_{2}$

section $\mathbf{E}$

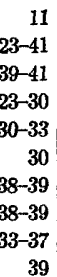

B

Saltation load, definition

Sampling zone, definition.

Sandhills region.

Schoklitsch equation.................... $66-67,77$

Sediment, mode of movement, definition.....

size analysis, section $\mathbf{A}$........................ section $B$.

section $\mathrm{B}_{1}$

section $\mathrm{C}_{2}$

section $\mathbf{E}$

Sediment and velocity, vertical distribution of section $\mathrm{D}$

Sediment concentration, definition

Sediment discharges, formulas for

formulas for, development of

measured, definition

total, definition.

unmeasured, definition

S

Einstein procedure ..............

Shear or tractive force.

Shear velocity, modified formula for ........... $46-47$

Size analysis of sediment. (See Sediment.)

Size distribution of bed material. (See also Sediment)......................... 68-70

Slope, water-surface, section A

section $B_{\ldots} \ldots \ldots \ldots$

section $B_{1} \ldots \ldots \ldots$

section $\mathrm{C}_{1 \ldots} \ldots \ldots \ldots$

Straub equation.............................. $61-62$

Surface creep, definition ...................... 7

Surface runoff, drainage area contributing to.. 11

Suspended load, definition ..................... 7

Suspended sediment, definition............... 8

measured, definition.................... 9

vertical distribution. ...................... 72-75

equation for........................... 70

Suspended-sediment discharge, formulas, basis

of - 8

measured, definition.................... 9-10

modified formulas for exponent 2 ........ 49-51

total, modified formula for computing ... . 47-48

section $B$.................................... 30,33

use of in computing bed-material discharge - 42-46

Suspended-sediment measurements, section C. $\quad 15$

Symbols, explanation of . ..................... 79-81

\section{$\mathbf{T}$}

Total load (see also Sediment load), section D, records of........................ 20

Tractive force. . ................................ 62

Turbulence flume.............................. 11-23

capability to suspend total sediment load_ $\quad 23$

description of ............................... 11

development of ........................... $5-6$

downstream side of ..................... 15-23

effect of on hydraulic and sediment char-

acteristies, section $\mathrm{E}$................ 39

effects of on river flow . .................. 12

purpose. 41

section C . ................................ 12-15

section D................................... 15-23

upstream side of ........................... 12-15

Turbulence-suspension theory ............... 8

\section{V}

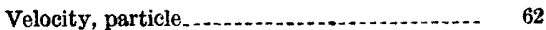

shear, modified formula for ............. $46-47$

stream, section A

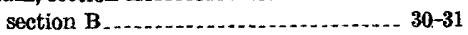

section $B_{1} \ldots \ldots \ldots$

section $\mathrm{C}_{1} \ldots \ldots \ldots$

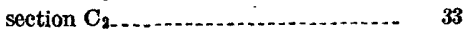

section E . 
Page 1 Page

Velocity and sediment, vertical distribution of, section D....................... 23

Water discharge, definition................... 8

normal ranges of

$\mathbf{W}$

section B.

Wash losd definition.

8,10 , variations in

$70-72$

z

0 